\title{
Africa for Africans: Métissage, Assimilation, and French West Africa's Cultural Evolution
}

\author{
Katherine Elizabeth Lakin-Schultz \\ Mathews, Virginia
}

M.A., University of Virginia, 2007

B.A., Duke University, 2003

A Dissertation Presented to the Graduate Faculty of the University of Virginia in

Candidacy for the Degree of Doctor of Philosophy

Department of French Language and Literature

University of Virginia

August 2014 


\begin{abstract}
This dissertation explores and traces the evolution of the role of cultural métissage as a philosophical response to colonialism in French West Africa (AOF). I use the West African press and select literary texts to show how and why assimilation and métissage emerged as a central debate, primarily in the 1930s and 1940s, with some attention given to the 1950s and the build up to African Independences (1960). Changes in colonial policy in the 1930s provoked heightened interest in the subject from the educated African elite and divergent camps formed with some rejecting assimilation (led by Léopold Sédar Senghor) while others promoted selective assimilation or cultural métissage (led by Ousmane Socé). The press and primarily, Paris-Dakar and later Dakar-Jeunes, became a platform for rich discussion between 1937 and 1942.

In my first chapter, I show how Ousmane Socé emerged as a vocal champion of cultural métissage in French West Africa. He used his novels and the press to promote métissage as the key to African cultural, economic, and social development. He was not in favor of replacing African culture with a French model, but was open to some outside cultural influence. Senghor, however, first sought to focus on cultural authenticity and my second chapter traces his philosophical evolution from his rejection of métissage in the 1930 s to his embrace of the philosophy in the late 1950s, exemplified through his conception of la Civilisation de l'Universel. Chapter 3 explores how the symbolic rivalry between Socé and Senghor, established after 1937, pushed Socé to launch a debate on cultural métissage in 1942 in the Vichy-sponsored newspaper, Dakar-Jeunes. I explain how this culturally-focused publication could exist in a period marked by reduced
\end{abstract}


liberties in AOF, hosting a rich exchange on the topic with the participation of West African intellectuals including Socé, Abdoulaye Sadji, and Mamadou Dia.

Lastly, my fourth chapter examines the role Sadji had in the métissage debate, focusing on his more nuanced approach. He never took Socé's or Senghor's side, but was active in the press, often using folklore to promote the value African cultural authenticity. My ultimate conclusion is that the dominance and duration of the debate on assimilation and cultural métissage in AOF points to Africans' desire to determine their own cultural future and have more autonomy. 


\section{Table of Contents}

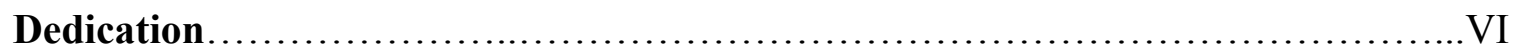

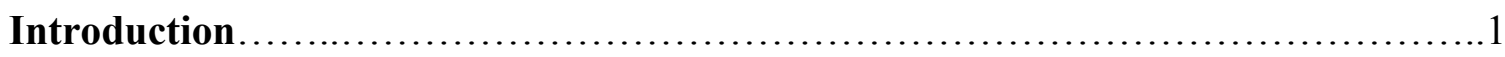

Chapter 1, Ousmane Socé: The Steady Champion of Cultural Métissage in French West

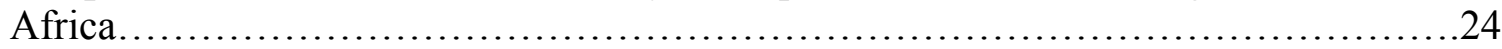

Chapter 2, From Negritude to “La Civilisation de l'Universel:" The Philosophical Evolution of Léopold Sédar Senghor.............................................73

Chapter 3, An Unlikely Host: Dakar-Jeunes, Cultural Métissage, and Vichy's National Revolution................................................................ 106

Chapter 4, Culture, Language, and Folklore: Abdoulaye Sadji's Nuanced Approach to Métissage................................................................. 153

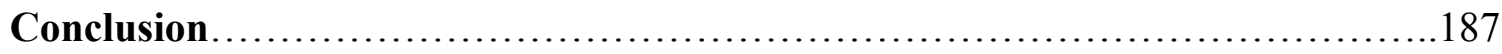

Appendix: Selection of Rare Texts............................................ 198

I. Abdoulaye Sadji. “Mirages de Paris: Préface.” Paris-Dakar 12 June 1937.............198

II. Mamadou Dia. "Fine analyse de la crise de conscience d'une génération." Paris-

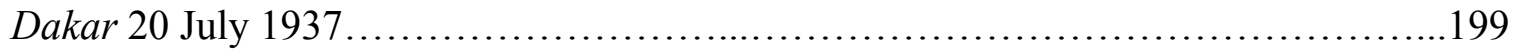

III. "La conférence de M. Diop Ousmané Socé a remporté un succès triomphal à la Chambre de Commerce." Paris-Dakar 3 August 1937.

IV. Ousmane Socé. “Impressions d'Europe.” Paris-Dakar 3 August 1937..............200

V. Léopold Sédar Senghor. "Le problème culturel en A.O.F." Paris-Dakar 8 September

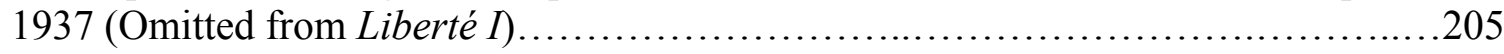

VI. Denis Blanche. "Préface" Congrès international de l'évolution culturelle des peuples coloniaux: Rapports et compte rendu (1937).......................................206

VII. Léopold Sédar Senghor. "La résistance de la bourgeoisie sénégalaise à l'école rurale populaire" Congrès international de l'évolution culturelle des peuples coloniaux:

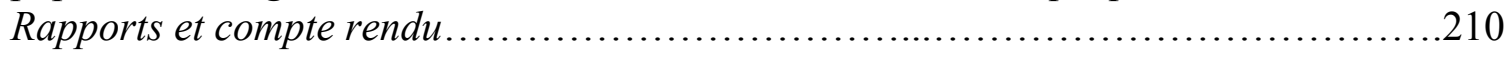

VIII. Fily Dabo Sissoko. "Les Noirs et la Culture." Congrès international de l'évolution culturelle des peuples coloniaux: Rapports et compte rendu...........................213

IX. Ousmane Socé. “Le Danger.” Paris-Dakar 29 September 1937.....................218 
X. Abdoulaye Sadji. “Utopie et Réalité.” Paris-Dakar 6 October 1937.

219

XI. Ousmane Socé. “Autour du Congrès de l'Évolution des peoples coloniaux.” Paris-

Dakar 4 January 1939.

XII. Fily Dabo Sissoko. "Réponse à Ousmane Socé: A propos du Congrès de l'Évolution Culturelle des peuples coloniaux," Paris-Dakar 27 January 1939 .223

XIII. Ousmane Socé. "Les noirs et la culture: Réponse à M. Fily Dabo Sissoko.” Paris-

Dakar 8-10 February 1939.

XIV. Ousmane Socé. “L’évolution culturelle de l'A.O.F.” Dakar-Jeunes 29 January

1942

Bibliography

.232 
Elsie, Lucie, Andrew, and my mother Linda 


\section{Introduction}

Nous nous trouvons mêlés, tout d'un coup à la vie universelle. C'en est fait des vieilles traditions dans tout ce qu'elles contiennent d'incompatible avec le monde nouveau qui se crée; nous nous métissons, tous les jours, dans tous les domaines de l'activité humaine. Et de ce métissage, va naitre, en terre africaine, un monde nouveau. ${ }^{1}$

By the end of $19^{\text {th }}$ century, France had emerged as a global imperial powerhouse.

The Berlin Conference of 1884 - 1885 guaranteed French control of a huge land mass in West and Central Africa, firmly establishing the nation's colonial presence from Mauritania to French Congo. The forced contact that resulted served to change the cultural, economic, and political landscape of the continent forever. As Africans tried to negotiate the many divergent influences that colonialism introduced, hybrid cultural identities also developed. This mixing or métissage defined simply by Le trésor de la langue française as "le croisement entre individus appartenant à des races différentes," permeated all levels of society, impacting urban areas more profoundly than rural ones due to increased contact with French colonizers and European institutions. ${ }^{2}$ The key lies in the notion of "croisement," which implies crossing or intersection and the absence of an adjectival qualifier allows for several interpretations. Best translated as hybridity, hybridization, or even mixing, métissage allows for the necessary extension of meaning beyond physical or biological métissage to that of culture, society, and language. I will therefore use the French terminology as the foundation for my dissertation investigating the evolution of the philosophy of cultural métissage in French West Africa (AOF). ${ }^{3}$

\footnotetext{
${ }^{1}$ Ousmane Socé Diop, Mirages de Paris (Paris: Nouvelles Éditions Latines, 1937) 148-9.

${ }^{2}$ Le trésor de la langue française informatisée: http://atilf.atilf.fr/tlf.htm.

${ }^{3}$ In French, Afrique Occidentale Française or AOF, the abbreviation that will be used throughout this study.
} 
The question of cultural métissage can be relevant to any study of the effects of colonization on colonized peoples, as some degree of manifested hybridity is an inescapable result of the kind of forced contact that defined the system. In Frenchcontrolled territories, French was introduced as the language of commerce and erudition, and written literature was first produced in the language of the colonizer, not Wolof, Bambara, or one of countless other native tongues. Though this new reality was indeed a hybrid one, it was not necessarily by conscious choice. Cultural métissage, in turn, evolved from the unavoidable result of the colonial culture clash to a dialectally important philosophical response to colonialism. The concept emerged in AOF in the 1930s during a period that was favorable to the participation of colonial subjects in public discussions on culture. Journalistic writings communicate that Africans were proactively looking towards the future, hoping to ensure a more constructive role in determining the cultural framework of their respective nations.

In its earliest demonstrations, the terminology 'cultural métissage' was used sparingly, and bled frequently into debates addressing the role of assimilation in West African society. However, if referenced explicitly as métissage or in terms of assimilationist or anti-assimilationist views, the source of the argument was the same. How did colonial subjects reconcile the opposing cultural forces acting on their lives? How could the lessons and dogmas acquired through the French colonial education system coexist with traditional African cultural and societal norms? What traditions should be reformed? What European contributions should be rejected or adopted? These questions were frequently addressed in both literary and journalistic texts with cultural métissage emerging as a common approach for promoting African progress in a colonial 
and soon-to-be post-colonial world. Proponents of cultural métissage believed in a middle ground where Africans could preserve the foundations of indigenous culture while simultaneously being open to select enrichment from France. In his 1937 speech at the Dakar Chamber of Commerce entitled “Impression d'Europe," Senegalese intellectual and métissage theorist Ousmane Socé explains:

Commençons par la connaissance profonde de nous-mêmes, de nos qualités, de nos défauts, de nos forces, de nos faiblesses et de nos véritables aspirations. En un mot, pour le monde nouveau que nous voulons créer, semons avec des graines qui soient non seulement viables sur le sol africain mais aussi des graines dont les produits seront des bienfaits pour le peuple noir. ${ }^{4}$

Cultural métissage can occur when two or more poles of cultural influence intersect and the philosophy of cultural métissage is the critical approach to this phenomenon. In the the case of French West Africa, theorists like Oumane Socé sought to determine what elements of each of culture should be adopted, adapted, or rejected to best foster positive advancement in the territory. The hope was for each pole to become better and more productive while simultaneously maintaining its unique cultural distinction. Edwin Hill notes that "while cultural syncretism unites through the erasure of difference, the notion of métissage, the weaving together of cultures without their complete syncretisation, helps to reinforce the integrity and coherence of the self or nation." distinction when considering the philosophy of cultural métissage as it was perceived in French West Africa. Proponents of cultural métissage believed that a new world order,

\footnotetext{
${ }^{4}$ Ousmane Socé “Impression d'Europe” Paris Dakar 6 Aug. 1937: 2.

${ }^{5}$ Edwin Hill, "Imagining Métissage: the Politics and Practice of Métissage in the French Colonial Exposition and Ousmane Socé's Mirages de Paris, "Social Identites 8.4 (2002): 631. 619 - 645 citation p. 631
} 
defined by increased contact between nations and cultures, was taking shape and that Africans had to evolve if they wanted to compete on a global scale.

This may seem to be a natural and inevitable response to the colonial situation. French colonialism, however, presented a whole host of rhetorical inconsistencies that made the willing adoption of French culture problematic for increasingly informed and politically engaged Africans. Even if the economic exploitation of the colonies was a top priority, France also felt obligated to promote humanitarian initiatives in their vast Empire. Education was a key component of France's colonial philosophy, but increased opportunities for academic success did not erase the subversive racial and cultural hierarchies that were necessary to maintain colonial control. Many educated Africans became increasingly aware of the unavoidable inequalities and grew resentful of an administration that did not truly value Africa's rich heritage and that strictly limited access to higher education. As cultural métissage was being promoted in AOF, most vocally by Ousmane Socé, an opposing camp that favored the promotion of African cultural authenticity also emerged. Similarly to the burgeoning Negritude movement in France, those preaching cultural authenticity in AOF were rejecting the subversive rhetoric of their colonial education. Likewise, a full embrace of métissage risked diluting their anti-assimilationist message.

The question of cultural métissage is equally relevant today and the debates that inform much of this dissertation will never be truly resolved. New interpretations and theoretical extensions of cultural métissage continue to shape our understanding of an increasingly interconnected world that is still profoundly influenced by the past. Imperial ties were not cleanly severed after Independence and the challenge of negotiating cultural 
influence in AOF did not fully fade after colonialism's official demise. Theories revisiting and redefining notions of hybridity and métissage have become influential in post-colonial theory. In Chapter 2, I explore how Léopold Sédar Senghor evolved from a young intellectual wary of métissage and against assimilation to one of the concept's must influential theorists. Senghor's conception of "La Civilisation de l'Universel," the philosophy that dominated much of his prose after 1957 is indeed a precursor to the highly theoretical notions of hybridity that have been influencing academic discourse in more recent years. ${ }^{6}$

The related concepts of métissage and hybridity have significantly shaped literary theory with publications like Édouard Glissant's Le Discours antillais (1981) and Introduction à une poétique du divers (1996), Françoise Lionnet's Autobiographical Voices: Race, Gender, Self-Portraiture (1989), and Homi Bhabha's The Location of Culture (1994), all of which investigate how these notions appear in both texts and culture. These highly theoretical works address hybridity and métissage in a postcolonial world and analyze the ways in which the inevitable contact of cultures continues to shape not only literary trends, but global culture in a world defined by lingering social hierarchies, constant migrations, and the increasingly open flow of information. Socé, Senghor, Glissant, Lionnet, and Bhabha and are ultimately all responding to the same phenomenon, but the métissage touted in French West Africa was far less theoretical,

\footnotetext{
${ }^{6}$ [Les races] sont d'une égalité complémentaire. Et la Civilisation de l'Universel se situe exactement au Carrefour des valeurs complémentaires de toutes les civilisations particulières. Pour cette raison, mon pays, le Sénégal, tente, en Afrique noire, un effort culturel original et, peut-être, sans précédent. Nous voulons nous enraciner au plus profond de l'Africanité, dont la Négritude n'est qu'un aspect, et, en même temps, demeurer ouverts aux quatre vents du monde [...].Léopold Sédar Senghor, Liberté I (Paris: Éditions du Seuil, 1964) 318.
} 
addressing the hybridization of culture more practically with the hope of guiding African cultural evolution with a program for cultural compromise.

In the introduction to Autobiographical Voices: Race, Gender, Self-Portraiture, Françoise Lionnet provides insight that helps distinguish the more recent theories on métissage and hybridity from those that were articulated in French West Africa. She explains:

For me métissage is a praxis and cannot be subsumed under a fully elaborated theoretical system. Métissage is a form of bricolage, in the sense used by Claude Lévi-Strauss, but as an aesthetic concept it encompasses far more: it brings together biology and history, anthropology and philosophy, linguistics and literature. Above all, it is a reading practice that allows me to bring out the inter-referential nature of particular texts, which I believe to be of fundamental importance for the understanding of many postcolonial cultures. ${ }^{7}$

In the 1930s and 1940s in AOF, cultural métissage was both a theory and a proposed practice (praxis). Lionnet, however, also addresses métissage as a useful tool for textual and cultural interpretation. Though Senghor's conception of "La Civilisation de l'Universel" shifts away from the practical application of métissage preached by Ousmane Socé towards a more utopian universalism, he was still presenting a framework for the positive evolution of culture, not necessarily for literary analysis. Though deciphering the métissage occurring in a text is relevant when trying to grasp the hybridity characteristic of post-colonial literary forms, genres, and language, I do not seek to interpret literature or cultural commentary through the lens of métissage. From Socé's Mirages du Paris to Abdoulaye Sadji's Tounka, the writings addressed in this study all contain rhetoric explicitly promoting or opposing cultural métissage and I seek

\footnotetext{
${ }^{7}$ Françoise Lionnet, Autobiographical Voices: Race, Gender, Self-Portraiture (Ithaca: Cornell UP, 1991) 8.
} 
to show the practical role the philosophy had in West African discussions and debates on culture.

In Introduction à une poétique de divers Édouard Glissant also presents métissage as a praxis, less theoretical in nature than 'créolisation,' his crowning philosophy. For Glissant, créolisation is the phenomenon shaping the world today and though related to métissage, he is clear that it is not the same concept. He explains that métissage is a conscious choice whereas créolisation is a natural and unavoidable trend that cannot be controlled. He explains, "Et pourquoi la créolisation et pas le métissage? Parce que la créolisation est imprévisible alors que l'on pourrait calculer les effets d'un métissage. [...] La créolisation, c'est le métissage avec une valeur ajoutée qui est imprévisibilité." 8 Indeed, cultural métissage in AOF was a meticulously calculated and consciously constructed philosophy with individual intellectuals promoting differing programs for the role of métissage in Africa's cultural future. Glissant's notion of créolisation is in many ways a direct descendant of Senghor's "Civilisation de 1'Universel," as both philosophies communicate the universality inherent in their seemingly utopian conceptions:

La thèse que je défendrai auprès de vous est que le monde se créolise, c'est-à-dire que les cultures du monde mises en contact de manière foudroyante et absolument consciente aujourd'hui les unes avec les autres se changent en s'échangeant à travers des heurts irrémissibles, des guerres sans pitié mais aussi des avancées de conscience et d'espoir qui permettent de dire - sans qu'on soit utopiste, ou plutôt, en acceptant de l'être - que les humanités d'aujourd'hui abandonnent difficilement quelque chose à quoi elles s'obstinaient depuis longtemps, à savoir que l'identité d'un être n'est valable et reconnaissable que si elle est exclusive de l'identité de tous les autres êtres possibles. ${ }^{9}$

Lionnet, however, raises a provocative question about universalist philosophies like Glissant's and Senghor's as she claims that they are ultimately endorsing an eventual

\footnotetext{
${ }^{8}$ Édouard Glissant, Introduction à une poétique de divers (Paris: Gallimard, 1996) 18-19.

${ }^{9}$ Glissant, Introduction 15.
} 
merging of cultures, demanding a politics of assimilation: "Universalism demands a politics of assimilation, incorporation, or resistance, instituting a structure of vertical struggle for recognition and citizenship. Like many scholars, we find universalist constructs wanting [...]."10 Much of the debate on cultural métissage in AOF equated cultural métissage to assimilation, but I argue that proponents of métissage were not proponents of assimilation. The notion articulated in AOF promoted choice and compromise, asking Africans to take control of their future by being open to outside influences that could complement existing culture, not replace it.

Moreover, in AOF the debates that address cultural métissage and assimilation provide valuable insight into the questions that captivated African intellectuals in the last decades of colonial rule. More recent post-colonial theories of hybridity can certainly help us understand how related philosophies have evolved over time, but they reference a very different reality and serve a different purpose than newspaper articles addressing the issue of culture in French West Africa between 1937 and 1942, for example. Since colonialism was still in full force, cultural métissage in AOF was presented as a program: a proposed social and cultural construct determining the degrees of assimilation to promote or reject. Lionnet and Glissant provide insight into the hybridity intrinsic in post-colonial literature, culture, and language. My approach, however, is more literal and less theoretical. I present literary texts and journalistic publications that explicitly argue for or against the need for métissage in West African society, and though these debates certainly inform more recent discourse on hybridity and métissage, I do not apply outside theories to the texts in question. I seek to show, rather, what Africans were saying at the

\footnotetext{
${ }^{10}$ Françoise Lionnet et Shu-mei Shih, ed., Minor Transnationalism (Durham: Duke UP, 2005) 2.
} 
time, in an effort to better understand what social and cultural issues were important and why.

Though related ideas were circulating in France as early as the mid 1920s, I focus on the question of cultural métissage in AOF from the mid 1930s through the wave of African Independences (1960), relying largely on the work of three thinkers: Ousmane Socé, Léopold Sédar Senghor, and Abdoulaye Sadji. Chapters are dedicated to exploring each man's individual interpretation and view of cultural métissage and their respective roles in the concept's evolution. Only the third chapter strays from this model, focusing not on a single author, but the publication Dakar-Jeunes that hosted a debate on cultural métissage in 1942. Socé initiated the discussion citing Senghor and French Sudanese ${ }^{11}$ intellectual Fily Dabo Sissoko’s opposing views as inspiration. Sadji and several other notable literary figures contributed to the unique publication, providing invaluable insight into the issues shaping Africans' favorable or critical view of the topic. The 1930s serve as my historical foundation due to the dynamic dialogue that was occurring in both French West Africa and France at the time. In France, this was manifested as Negritude while in AOF, a heated debate on assimilation and cultural métissage began that would continue well into the war years. Though the terminology can be problematic with both métissage and assimilation frequently used to refer to similar concepts, the nature of the debate was consistent. Africans were deeply split on how to reconcile the dual forces acting on their lives.

Though one cannot attribute a date to the foundation of the discussion, there is evidence that like notions were touted as early as the 1920s in France. Philippe Dewitte, in Les movements nègres en France: 1919-1939, explains that French leftist political

\footnotetext{
${ }^{11}$ Present day Mali.
} 
groups sponsored most of the Pan-African journals of the twenties and that assimilationist rhetoric dominated their content. Le Libéré was a journal published in Paris between 1923 and 1924 that was advertised as the "Tribune du peuple malgache." On the front page of each issue there is a "déclaration" rubric, written on behalf its editors that outlines the journal's expressed purpose. It reads “[...] Le Libéré entend combattre toute injustice de quelque côté qu'elle vienne. Il ne souffrira aucun abus, Européens et Indigènes, dont les intérêts sont lésés, trouveront leur défense dans ses colonnes. La VÉRITÉ une et indivisible, n'a pas de couleur. C'est ainsi que Le Libéré entend faire son devoir."12 On the first page of the publication's January 15, 1924 issue, in a column juxtaposed with an article by frequent contributor Réné Maran, ${ }^{13}$ Kojo Tovalou makes a claim similar to the theory outlined by Ousmane Socé a decade later and eventually to Senghor's universalist conception that emerged in the late $1950 \mathrm{~s} .{ }^{14}$ In an article entitled “Étrennes d'un indigène à ses frères," he writes, "Il existe diverses civilisations à la surface du globe, elles doivent se marier, se compénétrer, s'élargir pour devenir la civilisation mondiale et véritablement humaine."15 Aside from the inclusion of the term itself, Tovalou alludes to the same concepts enumerated by the protagonist in Ousmane Socé's second novel, Mirages de Paris (1937) when he explains "nous nous métissons, tous les jours, dans tous les domaines de l'activité humaine. Et de ce métissage, va

\footnotetext{
12 "Déclaration" Le Libéré: Tribune du peuple malgache, 15 May 1923: 1.

${ }^{13}$ Réné Maran was a Martiniquan intellectual and the author of the novel Batouala (1921) and several other publications. He won the Prix Goncourt for Batouala despite being critical of colonialism, even if only in the novel's Preface. He was active in the Pan-African movements of the 1920s in Paris and influenced Negritude's founders.

${ }^{14}$ Tovalou is introduced to readers: "Nous n'avons pas besoin de présenter aux lecteurs du Libéré le prince Kojo Tovalou Houenou, petit-fils de l'ancien roi du Dahomey, Behanzin. Docteur en médecine, avocat à la Cour d'appel, professeur à l'École des Hautes Études Sociales, il appartient à l'élite intellectuelle de Paris et du monde. Sa collaboration honore le Libéré, de même que sa haute valeur doit être la fierté des indigènes de nos colonies (Note de la Rédaction). Le Libéré 15 Jan. 1924: 1.

${ }^{15}$ Kojo Tovalou Houenou, "Etrennes d'un indigène à ses frères" Le Libéré 15 Jan. 1924: 1.
} 
naître, en terre africaine, un monde nouveau." "16 Though Dewitte is quick to link Tovalou's musings to French cultural allegiance, this text suggests that related ideas were circulating in France a decade prior to the publication of Mirages de Paris while simultaneously highlighting assimilation's problematic definition and often misleading connotations. $^{17}$

The Trésor de la langue française defines assimilation as "l'action de rendre semblable et même identique à quelqu'un ou à quelque chose, soit par intégration complète dans un autre être ou une autre substance, soit par une comparaison procédant d'un acte de jugement ou de volonté." 18 The African intellectuals (writers and politicians) that were considered assimilationist both in AOF and France, however, did not promote French culture as a viable replacement for indigenous culture, yet the label emerged as an unlikely synonym for supporters of cultural métissage. Ousmane Socé, cultural métissage's most vocal proponent in AOF before the Second World War, was considered by some of his peers as assimilationist, yet he exhibited a deep respect for African culture and history in his writings. ${ }^{19}$ He was, however, open to certain European contributions and believed that some African traditions should be approached with a critical eye.

Moving forward, it is necessary to acknowledge the nuance associated with assimilation as its meaning can vary according to the source. Though present, the term métissage was used less frequently by colonial subjects in the 1920s and 1930s with assimilation or assimilationist more frequently referring to any vocal acceptance of French influence into African life. Africans who were considered assimilationist did not

\footnotetext{
${ }^{16}$ Ousmane Socé Diop, Mirages de Paris (Paris: Nouvelles Éditions Latines, 1937) 149.

${ }^{17}$ Philippe Dewitte, Les mouvements nègres en France: 1919-1931 (Paris: L'Harmattan, 1985) 73.

${ }^{18}$ Le trésor de la langue française informatisée: http://atilf.atilf.fr/tlf.htm.

${ }^{19}$ Mamadou Dia, Mémoires d'un militant du tiers monde (Paris: Publisud, 1985) 36.
} 
necessarily support colonial assimilation policy, but were generally proponents of assimilation-style education as well as cultural métissage Furthermore, assimilation when referenced by Africans in discussions on culture generally referred to selective assimilation, a necessary component of and acceptable synonym for, cultural métissage. Scholars, like Dewitte, have chosen to continue to use the assimilationist designation to refer to publications (and intellectuals) in the 1920s and 1930s that were open to varying degrees of European integration. I argue rather that Africans who were considered assimilationist were generally promoting cultural métissage.

When discussing cultural métissage, two main poles of influence define the discourse: the pole France and the pole Africa. Most of the texts examined were published in Dakar and bi-continental exchange was an unavoidable reality of life in AOF's sprawling capital and largest urban center. Elite schools and administrative jobs attracted a higher concentration of educated Africans than rural areas and by the 1930s a small, but active, intellectual community had formed. From Dakar, an even smaller group of the territory's best and brightest traveled to Paris as "boursiers," receiving one of the rare scholarships available for Africans to pursue higher education in France.

The intellectuals central to this dissertation completed their studies in either AOF or France in the late 1920s or early 1930s and have since been dubbed "la jeune génération des années trente," due to their dynamism and increased intellectual activity. ${ }^{20}$ Their paths are undeniably intertwined and they frequently entered into direct dialogue with one another in the press. Socé and Sadji both studied at the prestigious École William Ponty, and Senghor and Socé were in Paris together in the early 1930s and members of the same West African student group. They knew each other, dedicated

\footnotetext{
${ }^{20}$ Amadou Cissé Dia, “Adieu à Ousmane Socé Diop,” Bingo May 1974: 20.
} 
writings to one another, and were vocally supportive of each other's literary successes even if they may have disagreed at times on the best path for Africa's cultural evolution. Their relationships were marked by both harmony and discord, and they used the press and their respective publications as platforms to share their views. Paris-Dakar, French West Africa's main daily newspaper, has provided the most direct insight into the topics that defined this period, with métissage and assimilation being paramount. Its Vichy spinoff, the singular Dakar-Jeunes of 1942-1943, continued the discussion on métissage and assimilation that Socé, Senghor, and Sissoko helped establish in the latter half of 1930s. Sadji's view on cultural métissage was not as explicit as Socé's and Senghor's, but he was equally active in relevant debates and his ideas emerge from his concurrent publications. In October 1937, he expressed selective support for Socé's ideas in ParisDakar and contributed to the métissage debate in Dakar-Jeunes five years later, publishing an article simply entitled "Un point de vue." 21 He eventually dedicates his 1965 tale Tounka "à mon ami Ousmane Socé cette rapide vision de notre cher Cap-Vert." Socé, Senghor, and Sadji are linked not only by their Senegalese nationality, but because they respond to shared experiences of cultural indoctrination, academic success, and travel in their writings. All addressed, at various times in their careers, cultural métissage and the difficult path of negotiating cultural identity in a colonized space. Socé and Senghor were shaped by experiences on both continents and dialogue occurring in Paris undeniably influenced that of AOF and Dakar. Understanding the particularities of each pole will help frame our continued discussion.

Founded in 1895, Le Governement Général de 1'Afrique Occidentale Française was established to move colonial decision-making away from France. From the capital

${ }^{21}$ Abdoulaye Sadji “Un point de vue” Dakar-Jeunes 12 Mar. 1942: 10. 
of Dakar, the colonial administration hoped to establish more effective control over a territory seven times the size of France that included Senegal, French Sudan, Guinea, Ivory Coast, Dahomey, Mauritania, and Niger, with Upper Volta and Togo joining in 1919. ${ }^{22}$ By 1936, the population of AOF was approximately 15.5 million with only 20,000 Europeans (of whom 4,000 were civil servants working for the administration and 3,900 military personnel). Dakar was by far the largest city with a population of 92,500 and no towns outside of Senegal had a population over $25,000 .^{23}$ The territory was, therefore, almost entirely rural and the vast majority of Africans led a traditional lifestyle. Before the Second World War, only five percent of Africans had attended a French school, but Tony Chafer in The End of Empire in French West Africa, observes that this seemingly small proportion sufficed to maintain a well-established class of évolués or educated Africans who were able to hold jobs as lower-level civil servants in the administration. Of these, an even smaller, more elite class emerged, many of whom, like Socé and Sadji, studied at the École William Ponty, the pinnacle of higher education in AOF. The most promising students from across the territory came to Gorée Island to learn and graduates often became schoolteachers, medical assistants (médecins africains), veterinarians, and administrative officers. ${ }^{24}$ Few received scholarships to pursue higher education in France.

The debate on cultural métissage largely originated among members of the West African elite, since they had the longest and most extensive access to a French colonial education and their lives were, therefore, profoundly affected by both poles of influence.

\footnotetext{
${ }^{22}$ Tony Chafer, The End of Empire in French West Africa (Oxford: Berg, 2002) xv.

${ }^{23}$ Chafer, End of Empire 28.

${ }^{24}$ All of the men considered in this study who attended William Ponty studied on Gorée Island. The school was founded as L'École Normale in Saint-Louis in 1904, it moved to Gorée in 1913, and finally to Sébikotane in 1938. Chafer, End of Empire 51.
} 
Education was a core component of France's unique style of colonialism and these highly successful students underwent years of cultural indoctrination as they moved through the system. Armed with the tenets of the civilizing mission, France felt its duty was to share its cultural and linguistic riches with those deemed less fortunate and schools were the primary arm of outreach and propaganda. The nation who authored The Declaration of the Rights of Man and of the Citizen felt it had an obligation to the primitive peoples of Africa and it executed a form of colonialism that justified its often-unjust actions with a belief of the inherent good of its project. In A Mission to Civilize: The Republican Idea of Empire in France and West Africa, 1895-1930, Alice Conklin explains:

The notion of a civilizing mission rested upon certain fundamental assumptions about the superiority of French culture and the perfectibility of humankind. It implied that France's colonial subjects were too primitive to rule themselves, but were capable of being uplifted. It intimated that the French were particularly suited, by temperament and virtue of both their revolutionary past and their current industrial strength, to carry out this task. [...] It assumed that the Third Republic had a duty and a right to remake "primitive" cultures along lines inspired by the cultural, political, and economic development of France. ${ }^{25}$

With education being the civilizing mission's greatest tool, the administration sought to promote Western values and teach basic literacy in French across AOF in an effort to ensure Africans' limited evolution. Those who succeeded in advancing academically could bolster the administration's success by serving as official mouthpieces and representatives of French interests in rural areas through their knowledge of both French and native tongues. The principles of liberty, equality, and fraternity had to be loosely interpreted as the power needed to ensure colonial domination also required the subjugation of colonial subjects resulting in an unavoidable glass ceiling on all

\footnotetext{
${ }^{25}$ Alice Conklin, A Mission to Civilize: The Republican Idea of Empire in France and West Africa, 18951930 (Stanford: Stanford University Press, 1997) 1-2.
} 
professional and academic fronts. Even members of the African elite, having arrived at the zenith of academic success in AOF, were limited in their choice of professions. Ousmane Socé had to pursue veterinary studies in France, as scholarships to medical school were not available to Africans. Such scholarships for study in France were also extremely limited. Senghor once noted that in the 1930s, there could not have been more than ten West Africans pursuing higher education in France. ${ }^{26}$ It was however this small, elite class that would shape dialogue on cultural evolution in AOF. Their diverse experiences across AOF and in France afforded a unique perspective on the colonial situation and the issues facing African society. Many cite their first encounter with French school as a powerful moment of rupture where the innocence of childhood, marked by village life or early Koranic education, was replaced by the confusion of forced hybridity. Education is therefore central in understanding métissage, as it was the primary gateway to French linguistic and cultural fluency.

By the mid-1930s, most of the intellectuals I consider had already finished their studies in either France or AOF and were holding jobs, many as teachers, with the exception of Ousmane Socé, who was a veterinarian. Senghor symbolized the pinnacle of achievement after becoming the first African agrégé, securing a post in Tours and residing primarily in France well into the following decade. Sadji did not pursue studies in France until 1948, when he left Senegal for just over a year to pass the exam to become a primary school inspector. In 1930, it was Ousmane Socé who earned the one coveted scholarship to study at École Vétérinaire de Maisons-Alfort. Sadji remained in Senegal working as a teacher. He began publishing actively in the press as early as 1936

\footnotetext{
${ }^{26}$ Léopold Sédar Senghor “Adieu à Ousmane Socé Diop,” Bingo May 1974: 20.
} 
and by the advent of the Second World War, Sadji had emerged as a leader in the intellectual community in AOF.

After reaching the highest possible degrees of success, these men emerged on the other side of the colonial education system intimately aware of both its hypocrisies and its strengths. The end of their studies and beginning of their professional lives also corresponded to a period of policy change in the territory as a more liberal administration in AOF appointed by the Popular Front government in 1936 expanded on pre-existing association policies, granting more liberties to colonial subjects. ${ }^{27}$ The mainstream press in AOF became more open to contributions from colonial subjects and Senghor, Socé, Sadji, Mamadou Dia, and Fily Dabo Sissoko are among those who published articles in Paris-Dakar, addressing diverse topics including education, assimilation, and African cultural evolution. In France, the increased cultural and political engagement of young African and Caribbean intellectuals that gave birth to the Negritude movement was also

\footnotetext{
${ }^{27}$ Tony Chafer gives an excellent overview of the Popular Front's rise to power in 1936 and its implications in French West Africa in the first chapter of his book, The End of Empire in French West Africa: France's Successful Decolonization? Though the new party in power made domestic reforms a priority, a number of progressive changes were earmarked for the colonies. The Popular Front's arrival was met with enthusiasm in Africa, especially among the educated African elite who were supportive of the reforms this leftist political coalition promised, including freedom of the press, freedom of movement, forced labor reform, and the right to belong to a trade union. Chafer also notes that with these reforms came an upsurge of political activity that may have "portended the development of nationalism" in France's colonies and overseas departments, one of many factors that may have led to the ultimate dissolution of the Empire. Chafer, End of Empire 33-37.

Ruth Ginio, on page 5 of her book French Colonialism Unmasked: The Vichy Years in French West Africa, adds that Marcel de Coppet, the Governeur-Général of AOF appointed during the Popular Front years, brought a radically different approach to colonial rule. De Coppet, in contrast to his predecessors, seemed genuinely dedicated to social justice, as seen in his commitment to reforming labor laws and legalizing trade unions. Ginio explains, "one of his greatest achievements was the formation of the Inspection du travail - an organ that was to examine work conditions in both the public and the private sectors and to regulate labor recruitment." For more on the "Colonial Popular Front," see James E. Genova's article "The Empire Within: The Colonial Popular Front in France, 1934 - 1938," Alternatives: Global, Local, Political, 26.2 (April - June 2001): 175-209.
} 
well underway. ${ }^{28}$ These combined elements served to facilitate a more favorable environment for cultural dialogue on both continents. ${ }^{29}$

As academic success is the common denominator for all of those who shaped discourse on cultural métissage, it is important to understand the policy driving France's unique approach not only to colonial education, but to colonialism in general and therefore the difference between assimilation and association. Tony Chafer in "Teaching Africans to be French: France's 'Civilizing Mission' and the Establishment of a Public Education System in French West Africa, 1903-30" notes the difficulty of defining French colonialism as assimilationist or associationist: French colonial policy was dynamic and terminology was used inconsistently across the Empire. He claims that association emerged as a doctrine in Paris in the 1890 s as assimilation was quickly seen as impractical and nearly impossible to implement in such an expansive territory. Alice Conklin observes, however, that the term association was not used in Dakar before the First World War. Indeed it seems that assimilation in the pure sense was never fully implemented in AOF, outside of the Senegal's four communes: Rufisque, Gorée, Dakar, and Saint-Louis where the population, referred to as "les assimiliés," enjoyed special privileges from citizenship to the right to send a representative to the National Assembly in Paris. ${ }^{30}$

\footnotetext{
${ }^{28}$ The journal "L'Étudiant noir" was published in March of 1935 and is often considered one of the first manifestations of Negritude with contributions from both Aimé Césaire and Senghor with Damas serving as editorial secretary. Gary Wilder, The French Imperial Nation State: Négritude and Colonial Humanism Between Two World Wars (Chicago : University of Chicago Press, 2005) 187.

${ }_{29}$ Senghor had a presence on both continents and his ideas influenced thought in both intellectual circles. Senghor's helped establish L'Étudiant noir in Paris in 1935 and contributed to the press in AOF in 1936 and 1937. He returned to Dakar in the summer of 1937, delivering a controversial speech critiquing blind assimilation, "Le problème culturel en A.O.F.," that inspired increased dialogue on the topic in AOF.

${ }^{30}$ Association policy replaced assimilation policy when the idea of "creating France overseas" was proven impossible. Association style colonialism sought to maintain the balance of power by being less disruptive to African political and social structures, no longer seeking to fully replace them with the French model. It
} 
In the 1930 s the debate on métissage was linked to differing views on the role of assimilation in colonial education among the African elite. Chafer explains:

There has been an enduring belief that France was, fundamentally, assimilationist in its approach to education in Africa. The emphasis on the use of the French language, the fact that the education system was under government, rather than church, control, the fact that French Black Africans appeared more francisé and shared a French outlook on life to a greater degree than their British counterparts, and the widespread use of French teachers in schools: all these have been taken as signs that French colonial education policy in Black Africa was basically assimilationist. ${ }^{31}$

Though Chafer later argues that associationist policy may have influenced education policy as early as 1903, the view of education as assimilationist, by Africans themselves is central to understanding and situating the debates that inform this study of cultural métissage. Many Africans, including Socé, clung to the guarantee of assimilationist education, acknowledging it to be the only path to professional success in AOF at the time. Indeed, if Africans wanted financial stability or the Western-style amenities of urban life, a French diploma facilitated these goals. The institution of l'École rurale populaire in 1934 by the colonial administration in AOF instead offered a more Africanized education, adapted specifically to rural life. The goal was to promote basic literacy and facilitate traditional livelihoods, eliminating much of the French curriculum that was less relevant to village life. If the new schools were very popular among rural populations, many of the African elite and assimilé population saw this as the administration's attempt to further limit academic success. For the educated elite of the

\footnotetext{
also came to be a way of maintaining the necessary colonial hierarchy by ensuring Africans' subjugation, limiting access to modern ideas. Association policies were best exemplified in rural areas where colonial power ruled through African intermediaries who agreed to collaborate with administration and its policies. "Chef de cantons" and "chefs de village" served to promote French interests in rural villages, collect taxes, recruit labor, and keep the administration abreast of indigenous issues. Chafer, The End of Empire 29-30.

${ }^{31}$ Tony Chafer "Teaching Africans to be French: France's 'Civilizing Mission' and the Establishment of a Public Education System in French West Africa, 1903-30” Africa: Rivista trimestrale di studi e documentazione dell'Istituto italiano per l'Africa e l'Oriente 56.5 (June 2001): 191.
} 
four communes, these reforms were only acceptable if strictly limited to rural AOF and this meant keeping education largely French.

This resistance to rural school reform and the resulting discussion on assimilation in education was the likely precursor to the broader debate on cultural métissage that began in 1937. Those who supported cultural métissage, with Ousmane Socé being the most vocal and prolific proponent at the time, called for selective assimilation citing French education as integral for African development and advancement. Senghor would become the symbolic leader of the opposing camp, the anti-assimilationists, and his support of l'École rurale populaire is not surprising considering his philosophical trajectory. His writings both in both France and AOF between 1935 and 1937 reflect Negritude's early influence. Deemed as “les années de l'ivresse du nègre nouveau en France" by Senghor himself, the dynamism of the 1930s is reflected both in the Parisian student palavers that came to define Negritude and in the debates on assimilation that simultaneously impassioned many in AOF. ${ }^{32}$ The connections between the two poles can be traced through bi-continental movement and publication. Socé and Senghor were read and published on both continents. Socé, though not widely considered alongside Senghor, Césaire, and Damas to be one of Negritude's founders, was in Paris concurrently. He served on the West African Student Association that joined forces with the Martinican Student Association to publish 1935's L'Étudiant noir: the single-issue journal that many consider to be Negritude's first print manifestation. Senghor published

\footnotetext{
${ }^{32}$ In "Le message de Goethe aux nègre-nouveaux," Senghor writes “Ce furent, entre 1930 et 1939, les années d'ivresse du Nègre Nouveau en France. Munis des armes miraculeuses de l'écriture automatique, plus furieux que mitrailleuses, nous projetions sagaies empoissonnées et couteaux de jet à sept branches, nous faisions sauter tous les volcans de l'Éthiopie et ensevelissons, le jour de l'Ascension, tous les SaintPierre sous la pluie de feu de notre ressentiment. Nous le pensions du moins.” Léopold Sédar Senghor, Liberté I: Négritude et humanisme (Paris: Seuil, 1964) 84.
} 
several articles in AOF in 1936 and 1937 and Socé's novels, though published in France, were reviewed in Paris-Dakar. The close-knit group of African and Caribbean students responded to the deceptive realities of life in France by calling for racial and cultural valorization over racial and cultural subjugation. Senghor, who first defined Negritude as "les valeurs culturelles du monde noir," saw the values he, Césaire, and Damas were conceiving reflected in the creation of African rural schools that actively promoted tradition over assimilation. Feelings of exile and a longing for home defined Senghor's early poetry and it was these transcendent musings that embodied the ideals that sought to revalorize Black culture. Life in Paris seemed to magnify the hypocrisy of the system and the young men and women participating in the dynamic student groups increasingly understood that the assimilation rhetoric that defined their education could never be fully realized. The glass ceiling that ensured the delicate hierarchical balance was omnipresent in their lives both at home and in France, and Negritude was conceived as a response to an ever-subjugating status quo. The publications and social realities behind the formation of Negritude are well understood and have been extensively studied. What is seemingly overlooked in current scholarship, however, is the engaged debate on culture that began in the second half of the 1930s in French West Africa that suggests that the "ivresse" or exhilaration Senghor referred to was not limited to the Hexagon.

Though claiming that the debate on cultural métissage that occurred in AOF was directly linked to Parisian Negritude is difficult to substantiate, ${ }^{33}$ the importance of

\footnotetext{
${ }^{33}$ The creation of l'École rurale populaire may be the initial spark that launched the debate on culture that occurred in AOF between 1937 and 1942. No mention is made of Paris or Negritude in writings published in AOF at this time and there is no proof that official Negritude rhetoric had been propagated in Africa as publication linked to the movement was still extremely limited, even in France (Damas didn't publish Pigments until 1937). Senghor is the only go-between and it is clear that his writings in AOF were influenced by nascent Negritude philosophy. It is unclear, however, how much Africans living in and
} 
concurrent dialogues in both France and AOF in the 1930s strengthens our understanding of the issues that were informing the literary and social movements of the last decades of colonial rule. The proof of the exchange of ideas that was occurring in AOF between 1936 and 1942 can be found in the press. Select newspapers and periodicals published articles written by Africans, though their contributions can be easily overlooked, hidden on pages dedicated almost exclusively to French issues. From Senghor to Socé, Sadji, and Fily Dabo Sissoko, the pages of Paris-Dakar and eventually Dakar-Jeunes communicate the relevance of cultural métissage at the time. It appears to be the key debate of the late 1930s in AOF, and like Parisian Negritude, the question revolved around culture and how to move forward in a colonized space. For the founders of Negritude as well as West African "anti-assimilationists," this meant the strict promotion of African cultural values. For Socé and the supporters of selective assimilation and cultural métissage, the goal was cultural compromise where both poles, the African and the French could be negotiated to ensure positive development in an increasingly interconnected world. Beliefs and allegiances were certainly not static, especially in the case of Senghor, as he moves towards the embrace of cultural métissage gradually after the Second World War.

I seek to show the importance of cultural métissage as a response to colonialism, and trace its influence across three decades through a study of key figures and texts. By examining the works of Socé, Senghor, Sadji, and the many contributions to DakarJeunes, it is evident that the issues of assimilation and cultural métissage dominated discourse in French West Africa at the same time Negritude was first making waves in 
France. The texts investigated in this study prove that the West African elite was divided on how to reconcile the opposing cultural forces acting on their lives. From Socé's novels touting cultural métissage as the way of the future, to Fily Dabo Sissoko's strong rebuke of Socé's beliefs in 1939, and ultimately to Abdoulaye Sadji and Léopold Sédar Senghor's textbook, La belle histoire de Leuk-le-Lièvre, it is clear that negotiating cultural identity in a bipolar colonial world was a central theme driving cultural commentary and literary production.

What emerges, especially in writings from the 1930s and 1940s, is proof of West African intellectuals' desire to write their own narrative for the constructive cultural evolution of their respective countries, territory, and continent. Between the wars and into the 1950s, the key question was cultural authenticity: to assimilate or not to assimilate with cultural métissage emerging as a viable compromise with varying degrees of popularity and acceptance. I have constructed my project exclusively from the words of Africans themselves, from their ideas as expressed in the West African press and select literary works. Much has been said about Paris in the 1930s and the dialogues and resulting texts that gave birth to Negritude. Little has been written about the dynamic exchange of ideas that was occurring concurrently in French West Africa, yet the writings of the period reflect the desire to evolve on authentically African terms. Even if the Africa they envisioned was not always the same, Socé, Senghor, and Sadji wanted Africans to reclaim their voice, think critically about the cultural future of their continent, and influence positive change. 


\section{Chapter 1}

\section{Ousmane Socé: The Steady Champion of Cultural Métissage in French West Africa}

Ousmane Socé Diop's works have not maintained the same visibility as his contemporaries whose poetic and narrative texts have become mainstays of the Francophone African literary canon. A product of l'École William Ponty and the African and Caribbean intellectual community that thrived in Paris in the 1930s, Socé traveled in the same circles as Léopold Sédar Senghor, Aimé Césaire, Birago Diop, and Abdoulaye Sadji. In France, much of the early literary production from colonial subjects appeared in the form of short-lived journals and eventually poetry, yet Socé chose the novel as his first medium of expression. Though the 1950s saw an increase in novelistic production from African writers, Socé was well ahead of the trend publishing his first novel in 1935. Fictional prose is a medium well poised to communicate social commentary, and during this period characterized by dynamic change, discussion, and philosophical questioning, Socé used his novels to explore the complex issues facing a generation trying to reclaim a voice silenced by colonialism. His works reflect many of the tropes that defined not only this period of early African and Caribbean literary production, but Francophone literature for the years to come. They contemplate exile, disillusion, culture shock, racism, racial consciousness, and Mirages de Paris chronicles an important moment in the history of colonialism that was embodied with impressive pomp during the 1931 Colonial Exposition at the Parc de Vincennes in Paris. His novels' interest, however, as many of his contemporaries were quick to note, is less in their stylistic prowess than their 
philosophical content. ${ }^{1}$ His narrative works served as a platform to present the social and cultural commentary that would mark most of his writing. With his first novel taking place in Senegal and his second in Paris, Socé addressed the complexity of the colonial situation through his portrayal of life in AOF and France, as his protagonists struggle to navigate a bipolar world marked by divergent influences, pressures, and social obligations. His novels take the form of fictional case studies, describing the challenges facing Africans living in a colonized space. It is through the trials outlined in his novels and his extensive publication in the West African press that Socé presents and defines cultural métissage, propagating the concept on a large scale long before Senghor.

Though Socé's definition of cultural métissage can be derived from Karim, he seeks to break down his specific vision in chapter twelve of Mirages de Paris and prove the integral role that cultural métissage must have in fostering AOF's positive evolution. In a passage recounting a heated conversion between Fara, the novel's protagonist and Sidia, a literary prototype of the young African intellectual dedicated to what would soon become Negritude's expressed ideals, Socé provides a definition that can apply to much of his life's work on the subject. Referencing the inevitable contact between Africa and Europe, Fara explains:

Nous nous trouvons mêlés, tout d'un coup à la vie universelle. C'en est fait des vieilles traditions dans tout ce qu'elles contiennent d'incompatible avec le monde nouveau qui se crée; nous nous métissons, tous les jours, dans tous les domaines de l'activité humaine. Et de ce métissage, va naître, en terre africaine, un monde nouveau. ${ }^{2}$

For Socé, métissage is the only viable response to the colonial predicament and the true key to African development. His thoughts, however, are often misinterpreted and many

\footnotetext{
${ }^{1}$ Guy Ossito Midiohouan, L'idéologie dans la Littérature Négro-Africaine d'expression française (Paris: Harmattan, 1986) 72.

${ }^{2}$ Ousmane Socé Diop, Mirages de Paris (Paris: Nouvelles Éditions Latines, 1937) 148-9.
} 
of his contemporaries saw his views as purely assimilationist. In his autobiography, Mémoires d'un militant du tiers monde, fellow Ponty graduate, Dakar-Jeunes contributor, and future Prime Minister of Senegal Mamadou Dia, explains that Socé "prônait l'assimilation complète." Socé's writings tell a different story, and this chapter will not only outline his role as a vocal champion of cultural métissage in AOF, but also clarify the difference between assimilation and cultural métissage in the effort to debunk misconceptions regarding Socé's cultural allegiances.

Only when qualified as selective can assimilation be associated with Socé's writings. Most of his work on métissage contains three key elements: the description and praise of Senegalese culture with a particular focus on oral history and folklore, criticism of Senegalese culture (the unwillingness to adapt to the modern world, the lack of effective education for women), and elements of European culture that could promote African social and economic development. ${ }^{4}$ As métissage inherently includes mixing and exchange, it cannot occur without the adoption of select policies, customs, or in the case of AOF, the language of the colonizer. Socé does not, however, seek to promote the creation of a society modeled entirely after Europe or as he writes in Mirages de Paris, a society of "toubabs à peau noire." In his article entitled "Assimilation in $19^{\text {th }}$ Century Senegal," Oludare Idowu provides a definition for assimilation in the French imperial context that helps highlight the stark contrast between assimilation in the pure sense and the selective assimilation inherent in cultural métissage. He explains:

\footnotetext{
${ }^{3}$ Mamadou Dia, Mémoires d'un militant du tiers monde (Paris: Publisud, 1985) 36.

${ }^{4}$ The education of African women, or the lack thereof, was troubling to Socé as well as Abdoulaye Sadji. In Mirages de Paris during a discussion in which Fara and Sidia are discussing métissage, the shortage of educated women that would make fitting partners for the class of "évolués," is one of Fara's many arguments supporting not only his choice to marry a white woman, but for his whole proposed métissage project.

5 'Toubab' is a Senegalese/Wolof term for a person of European decent.
} 
The doctrine of assimilation [was based on] the belief of the power of Reason and the ability of all men to appreciate its universal value, and on the idea of a moral obligation to 'civilize' other nations. The Age of Reason conceived of man as a rational creature, and the French assumed that what was good for themselves as rational beings would also be good for other people of whatever colour, race, or cultural heritage. They set to reorganize native societies, which were considered to be inferior, in the light of French civilization, which was conceived as having attained the highest possible perfection. They believed that the slogan of Liberté, égalité, fraternité provided the perfect remedy for all human ills, and that it was their duty to apply the formula to the 'uncivilized' peoples. ${ }^{6}$

As previously noted in the Introduction, Le trésor de la langue française defines assimilation as "l'action de rendre semblable et même identique à quelqu'un ou à quelque chose, soit par intégration complète dans un autre être ou une autre substance, soit par une comparaison procédant d'un acte de jugement ou de volonté" and métissage as "le croisement entre individus appartenant à des races différentes." ${ }^{.7}$ Though this study, like Socé, extends the concept of métissage well beyond the empirical physical context implied by this definition, the most important distinction between the two notions is that assimilation is based not on 'croisement' or intersection but on replacing one thing with another. Even if full assimilation ultimately proved to be impossible and make way for the association policies employed by the colonial administration between the two wars, the use of the term "assimilation" in reference to Socé is misleading and inaccurate when not qualified as selective. Though Socé frequently acknowledged that the Europe had attained a much higher level of technological prowess than Africa, he countered these observations with examples of Africa's moral strength and cultural distinction. ${ }^{8}$

\footnotetext{
${ }^{6} \mathrm{H}$. Oludare Idowu, “Assimilation in $19^{\text {th }}$ Century Senegal” Cahiers d'études africaines 9.34 (1969): 210.

${ }_{8}^{7}$ Le trésor de la langue française informatisée: http://atilf.atilf.fr/tlf.htm

8 “En effet si l'Europe est arrivée à une apogée du développement technique et économique que l'on peut considérer comme « mec plus ultra » de ce que les hommes ont fait de tout temps dans cette voie, il n'en est pas moins vrai que le progrès moral n'a pas suivi le progrès technique. Des voix autorisées parlent de stagnation morale, d'autres plus pessimistes, vont jusqu'à dire régression morale. [...] Et c'est ici que l'Afrique prend sa revanche ; pour cette fois, elle se compare avantageusement à l'Europe. Sa vieille sœur
} 
The 1930s are of integral importance in the history of Francophone African literature. The decade marks a period of increased dialogue and publication among young colonial subjects living in Paris, a dialogue that would eventually give birth to Negritude. In studies dedicated to these critical years, the contributions of Senghor, Césaire, and Léon Gontran Damas are frequently cited. The accomplishments of these extraordinary talents should never be undervalued, however their primacy has served to overshadow the works of other important contemporary authors as well as the important intellectual activity occurring concurrently in French West Africa. Only through redirecting focus back onto AOF can one begin to understand the true extent of Socé's relevance and influence in both literature and politics until his death in 1973. Paris was, and still is, the epicenter of all literary production in French, but Dakar held a similar role in AOF. By directing scholarly inquiries to Dakar, the capital and administrative center of AOF, and by perusing the serial publications that were distributed across the expansive territory that defined French West Africa, one can understand how similar dialogues occurred on both continents. Though literary production from colonial subjects was more limited, in both scope and genre in AOF at the time, there is a clear evolution of thought that can be traced in works originating in both places. There are many authors, like Senghor and Césaire, who maintained a visible bi-continental influence in both literature and politics throughout their lives. There are also several important literary figures whose ideas were less frequently exported but who were influential in their home

\footnotetext{
commence à s'apercevoir que toutes ses richesses matérielles ne la rendent pas heureuse; elle s'aperçoit que son bonheur dépendra pour une large part de son perfectionnement moral qu'elle avait négligé dans ses conquêtes effrénées du monde de la matière. L'Afrique, elle, est encore pleine de scepticisme, de religions et d'idéal. Il nous faut donc, en imitant l'Europe, profiter de la leçon de son expérience, ne commettons pas à notre tour la maladresse de négliger ces grandes forces humaines que sont les valeurs morales. Il nous faut discerner. Il nous faut nous connaître d'abord avant de construire et ne jamais nous oublier en construisant." Ousmane Socé, "Impressions d'Europe," Paris-Dakar 6 Aug. 1937: 2.
} 
countries. Ousmane Socé and Abdoulaye Sadji both experienced some literary success outside of their homelands, but one must turn to AOF to truly understand the full extent of their literary and political contributions.

Socé's writings intimately reflect his experiences living in both France and Senegal and the philosophical inquiries that occur in his novels, articles, and short stories are steeped in discourse that conveys the influence both poles had on his life. A product and proponent of cultural métissage, Socé is the first prolific theorist of this philosophy in AOF. Unlike many of his critics who equated cultural métissage with assimilation, Socé saw a potential for mutual growth and betterment. Overshadowed by Senghor's later work on the topic, Socé's early role in discussions on cultural métissage is often undervalued. Cultural métissage is the primary theme that characterizes not only his literary production, but also most of his publications in the French West African press in the late 1930s and during the Vichy occupation of AOF. When in Senegal, Socé used the press as his main forum and platform, not only for expressing his philosophical ideas, but also for soliciting the participation of his compatriots in related discussions. This study, dedicated to tracing the evolution of the philosophy of cultural métissage, will focus here on Socé's own conception and promulgation of the philosophy in AOF. In addition to an analysis of the narrative texts that must be the foundation for any study of Socé, this chapter will then turn to his journalistic writings, namely in Paris-Dakar, Dakar-Jeunes, and later Bingo. ${ }^{9}$ Though his novels were more widely distributed, Socé's extensive contributions to the press in AOF have remained largely unstudied and, likewise, the extent of his influence during last decades of colonial rule deserves more attention.

\footnotetext{
${ }^{9}$ Though most explanation of Socé's role in Dakar-Jeunes is found in Chapter 3, which is dedicated solely to this publication.
} 
History has not been as kind to Socé as it has been to many of his contemporaries. Today, most of his work are out of print and have, in turn, been given little critical attention in recent years. Continually overshadowed by better-known literary figures both during his lifetime and posthumously, Socé can be enigmatic and elusive in current scholarship. Biographical information is scarce, and to get a more complete portrait of his political and literary activity in AOF, one must venture to the Senegalese National Library and Archives in Dakar. The only full-length study dedicated to Ousmane Socé is a dissertation entitled Vie et œuvre de l'écrivain sénégalais Ousmane Socé Diop:

Démonstration d'une injustice littéraire et intellectuelle, et révélation d'un moment caché de la littérature africaine. Pascal Brousseau aptly titles his doctoral thesis, as he provides in-depth historical and sociological context to Socé's literary and political activity. His study serves as an excellent reference for any scholarly project seeking to better understand his integral role in the nascence of Francophone African literature. ${ }^{10}$

Socé was born on October 31, 1913 in Rufisque, a town included in Senegal's four communes along with Dakar, Gorée, and Saint-Louis. His father was a merchant of Lébou origin and his mother from the Saloum region of Senegal. ${ }^{11}$ Like many in Senegal, his studies started in Koranic school before making his way through the colonial education system, first at the Lycée Blanchot and then at the École Normale William Ponty. He worked as a teacher and then received a scholarship to study in France at the École Vétérinaire de Maisons-Alfort. ${ }^{12}$ One of the first African “boursiers," Socé wanted

\footnotetext{
${ }^{10}$ Pascal Brousseau, Vie et æuvre de l'écrivain sénégalais Ousmane Socé Diop : démonstration d'une injustice littéraire et intellectuelle, et révélation d'un moment caché de la littérature africaine diss., University of Virginia, 2005.

${ }^{11}$ Sadji dedicates Tounka, a story that outlines the origins of the Lébou people, to Socé.

12 Birago Diop confirms Socé's stint as an "instituteur" in his tribute after his death that appeared in "Adieu à Ousmane Socé Diop,” Bingo May 1974: 20.
} 
to study medicine but was relegated to veterinary science as it was the only medical scholarship open to Africans at the time.

He arrived in France to begin his studies at Alfort, where he studied alongside Birago Diop, future author of Les contes d'Amadou Koumba. He travelled in the same circles as Senghor, Césaire, and Réné Maran and was profoundly marked by his time spent in France. While studying at Alfort, Socé also pursued studies in literature at the Sorbonne, but the government eventually threatened to revoke his scholarship if he continued, further proof of the many constraints placed on colonial subjects at time. Though biographical information on Socé is limited, after his death, several articles appeared in the local press that chronicled his life and accomplishments and gave insight into his reputation as a literary and political figure. Though this chapter will focus on Socé's literary contributions, his long-standing presence in government and public service proves the importance of his role as a national figure in Senegal during his lifetime.

Though Socé only published two novels, he also published a collection of traditional African folklore entitled Contes et légendes d'Afrique noire (1938) and a book of poetry, Rythmes de Khalam (1956). In the nearly twenty years between his last two publications, he was active in the local press, publishing frequently in daily newspapers. He founded the political journal Le Phare du Sénégal (1952) as well as the cultural magazine Bingo (1953). ${ }^{13} \mathrm{He}$ also embarked on a political career and though never reaching the prominence of Senghor, he served as Senator, was the Senegalese

\footnotetext{
${ }^{13}$ Brousseau 253.
} 
Ambassador to the United States, a permanent representative to the United Nations, and the Mayor of Rufisque, to list only a few of his official posts. ${ }^{14}$

In May 1974, more than seven months after his death, Birago Diop, Léopold Sédar Senghor and Amadou Cissé Dia all paid homage to their friend and countryman in Bingo, the magazine Socé founded and edited for many years. Though their relationship seems to have been marked by a certain rivalry due to Senghor's ever-eclipsing presence in both African literature and Senegalese politics, several writings suggest they were able to maintain a level of mutual respect. ${ }^{15}$ In his tribute, Senghor writes of his friend while acknowledging his often forgotten role in Negritude's early years:

On l'a trop souvent oublié, Ousmane Socé Diop était, avec nous, à Paris quand nous lancions, avec Césaire et Damas, le mouvement de la Négritude. Si l'on a moins parlé de lui, c'est qu'il n'était ni poète, ni théoricien et qu'il préférait faire vivre la vie que de théoriser sur elle. Il reste qu'Ousmane Socé Diop a été, avec Birago Diop et Abdoulaye Sadji, de la première génération des romanciers et conteurs sénégalais. ${ }^{16}$

Though I hope this study serves to disprove Senghor's claim that Socé was not a theorist, his contribution further confirms Socé's influence in both France and AOF. Senghor also provides rare insight into the student culture in Paris explaining that "l'histoire des lettres sénégalaises retriendra le nom de celui qui [...] nous a décrit la vie des 'Quatres Communes' entre les deux Guerres, mais aussi la vie des premiers étudiants ouest-

\footnotetext{
${ }^{14}$ On October 30, 1973, three days after Socé's death, Senegal's main daily Le Soleil published a an article on page 3 describing his funeral that included biography of the writer and politician: "Grand officier de l'Ordre national du Sénégal, le Dr. Ousmane Socé Diop était né en 1911 à Rufisque. Inspecteur vétérinaire, il fut en 1959, secrétaire général adjoint de l'Union progressiste sénégalaise. Maire de Rufisque depuis le 3 novembre 1965, M. Ousmane Socé Diop fut sénateur du Sénégal et secrétaire du Conseil de la République française de 1946 à 1948. Conseiller territorial de mars 1957 à novembre 1958, il sera successivement député (le 25 juin 1958), ministre du Plan de juin 1958 à avril 1959, puis représentant du Sénégal au Sénat de la Communauté d'avril 1959 à janvier 1961. Il est ensuite nommé premier ambassadeur du Sénégal aux États-Unis d'Amérique et représentant permanent aux Nations Unies. En même temps, le Dr. Ousmane Socé Diop était accrédité à Haïti, au Canada et au Mexique." "Le Sénegal dans la peine: Le Docteur Ousmane Socé Diop est mort samedi" Le Soleil 30 Oct. 1937: 1, 3.

${ }^{15}$ See "Tel est le sujet qui traitera ce soir M. Léopold Sédar Senghor," Paris-Dakar 4 Sept. 1937: 1.

${ }^{16}$ Léopold Sédar Senghor “Adieu à Ousmane Socé Diop,” Bingo May 1974: 20.
} 
africains en France, où dans les années 1930, nous n'étions pas plus de 10.” This direct reference, first to Karim then to Mirages de Paris, also provides a rare detail that further puts into perspective the passion and activism that inspired the creation of Negritude in the 1930s. This small group of ten (along with their Caribbean counterparts) helped change the course of history by launching a literary movement. Socé's role in this dynamic period is often overlooked, yet he was actively publishing earlier than most of his contemporaries. ${ }^{17}$

In his homage, Senegalese politician, playwright, and fellow Ponty alumni, Amadou Cissé Dia, also references the 1930s and Socé's role in the vanguard of Francophone African literature. He adds:

Pour notre jeune génération des années 30 , il fut le précurseur lucide et courageux qui a engendré des vocations littéraires. [...] Il a répondu à notre quête patiente et insatisfaite de nourritures littéraires adaptées à notre négritude, un miroir lumineux dans lequel chacun de nous se reconnaissait et reconnaissait les héros incarnés dans ses romans. ${ }^{18}$

Dia references key points that are important when considering the works of Socé, especially in the context of cultural métissage. Socé's support for cultural métissage, as seen in both Karim and Mirage de Paris, includes what he calls an "autocritique" or selfcriticism of Senegalese culture that many critics at the time seem to have misinterpreted. ${ }^{19}$ His goal, however, was to share the experience of "les Quatres Communes entre les deux Guerres, mais aussi la vie des premiers étudiants ouestafricains en France" to use the words of Senghor, in an effort to showcase not only the many challenges of the time, but also the richness of Senegalese culture. In doing do, regardless of any critique of style, Socé was creating a literature "adaptée à [sa]

\footnotetext{
${ }^{17}$ Léon Gontron Damas' Pigments was not published until 1937, the same year as Mirages de Paris.

${ }^{18}$ Amadou Cissé Dia, “Adieu à Ousmane Socé Diop," Bingo May 1974: 20.

${ }^{19}$ In addition to analysis in the chapter, see Chapter 3's discussion of Dakar-Jeunes.
} 
négritude" and therefore adapted to the experiences and concerns of his compatriots. He sought to underline the complexities of life in both Senegal and France, providing an honest portrait of the unique and divergent challenges that defined both experiences. In doing so, he confronted issues facing the traditional way of life in Senegal as well as those that were a direct result of the colonial situation. Africans were not excused from criticism as the philosophy that permeates his writings was based on universal selfawareness and open exchange. During this period of cultural awakening and burgeoning activism, however, Socé's form of social commentary was not always appreciated by his peers, as criticism of indigenous culture was swiftly associated with colonial empathy.

However, of these three tributes, all from important literary and political figures, Birago Diop's testimony is the most poetic. Writing not only about his career but his character, Diop was able to capture Socé's essence as an African writer who, like so many others, was forced to negotiate the uneasy path between French and their native language, tradition and modernity: in short, between Africa and Europe. Diop, addressing Socé directly, writes:

[...] Ta plume a rapporté en français, mais dès que nous étions entre nous, et même en compagnie d'étrangers ton wolof remontait inconsciemment de source.

Le virus littéraire qui t'avait été inoculé dès Blanchot et Ponty, t'avait, d'Alfort, fait pousser quelques pointes en Sorbonne. Mais la laisse était trop courte que nous avions tous au cou. Et l'ordre de Dakar, on te maintint sur le droit chemin du retour à la Terre, en te menaçant de te supprimer la bourse si tu continuait à vouloir parallèlement au doctorat vétérinaire, décrocher une Licence de Lettres. Qu'importait ! Tu n'avais pas besoin d'une peau d'âne de plus. La vocation était là impérieuse. (...)

Après exactement un bail de 3-6-9 dans ton métier de « Vélo de brousse », tu partis pour de bon vers tes primes amours vers la politique qu'en vrai Sénégalais polygame tu imposas à ta fidèle compagne la littérature.[...] 
S'il y a tant d'Ousmane et tellement de Diop, ta plus grande œuvre, ton suprême mérite sont d'avoir honoré ta mère en devenant et restant pour nous tous, Vétérinaires, Hommes de Lettres, Politiciens, Diplômâtes, tes collègues et confrères, simplement Socé. ${ }^{20}$

The admiration and respect Birago Diop felt for his friend shines through in this telling portrait. Not only does Diop poetically summarize Socé's accomplishments as well as his unique challenges, he provides insight into how Socé embodied his own definition of cultural métissage during his lifetime. Paying homage to Socé's African self, Diop references his use of Wolof and compares his balancing literature and politics with traditional Senegalese life. Rather than only extolling Socé's virtues, Diop references the honor he brought to his mother's name, since Ousmane Socé Diop was known primarily as Oumane Socé. Birago Diop's farewell is undeniably African in its conception, infused with language and references fitting only for a man who was Senegalese first. By not only speaking to Socé's literary and political merits, but by referencing his strong relationship with his native language and the honor he bestows on his family, Birago Diop communicates Socé's own métissage as a man who, Senegalese to his core, actively sought to reconcile the opposing cultural forces that marked his life. He thrived in a literary and political system that for so many years had a proverbial "laisse au cou," a figurative leash around the neck of all colonial subjects symbolizing colonialism's omnipresent glass ceiling. Through these tributes, published in a publication that Socé himself founded, one sees the legacy of a man whose death was greatly mourned. ${ }^{21}$

\section{Karim : Roman sénégalais}

Published in 1935, Karim: Roman sénégalais is the first example of narrative fiction from his generation of African writers. Described by Amadou Cissé Dia's as "la

\footnotetext{
${ }^{20}$ Birago Diop, “Adieu à Ousmane Socé Diop,” Bingo May 1974: 20.

21 "Le Sénégal dans la peine," Le Soleil 30 Oct. 1973: 3.
} 
jeune génération des années 30,” this group includes Senghor, Césaire, Damas, Birago Diop, Bernard Dadié, Fily Dabo Sissoko, and Abdoulaye Sadji: to mention those most relevant to this discussion. Socé's narratives are not explicitly anti-colonial in their conception but rather candid portraits of the colonial situation in both Senegal and France. Socé's rhetorical purpose is easily exposed as he couples praise and criticism for both poles of influence, weaving his ideas for African advancement into his texts. His prose is simple but clearly reflects the métissage he preached as he incorporates passages in Wolof as well as traditional folklore into his narratives. Though not explicitly linked, Socé's novels compliment each other by providing a bi-continental perspective of the trials associated with life in both France and Senegal. Most notably in Mirages de Paris, which was likely written entirely in Paris, Socé addresses the complex feelings of exile and the disillusion that would inspire not only the writings of this decade, but beyond from Césaire's Cahier d'un retour au pays natal (1939) to Cheikh Hamadou Kane's L'aventure ambiguë (1961). ${ }^{22}$

Unlike Mirages de Paris, Karim was composed, as least partially, in Senegal. Guy Ossito Midiohouan, in his book L'idéologie dans la littérature négro-africaine d'expression française, provides valuable insight into Socé's novels' inception as well as their reception among the author's peers. Though it is unclear if Socé had started Karim before arriving in Paris, Midiohouan suggests that it was his time at Ponty that drew him to literature. He explains:

Or nous savons que la mission idéologique de William Ponty était de faire sentir aux premiers intellectuels africains que leurs intérêts, leur destin, leurs espoirs dépendaient du système colonial. Ce fut l'école de la soumission, de la compromission et de l'équilibre à tout prix. C'est donc

\footnotetext{
${ }^{22}$ Midiohouan 72.
} 
à la lumière de cette réalité qu'il faut aborder l'œuvre d'Ousmane Socé Diop. $^{23}$

For Midiohouan, Karim is a novel dedicated solely to praising "les apports fécondants de l'Occident." Socé introduces his philosophy of cultural métissage by exemplifying the need to reevaluate outdated traditions that he felt hindered African advancement in favor of a new model that indeed borrowed from Europe. Midiohouan's assessment, however, is overstated. Though Socé's interpretation of cultural métissage was based on compromise, he was not simply writing an apology for colonialism. Likewise, he was not justifying the colonial situation, but rather proposing what he felt was the only viable solution for a society now forever impacted by dual and opposing influences. The reality was that France, even if uninvited, had made its linguistic and cultural mark on AOF and the nation's influence could not be simply erased, and nor should it be, according to Socé. It is important, however, not to equate this cultural reconciliation with a full-scale acceptance of colonialism and the inequalities it promoted. Socé's ideals are based on equality and compromise, not imposition. Though it is clear that Ponty graduates were greatly influenced by colonial rhetoric during their years at AOF's premier school, Midiohouan's assessment of the effect of this rhetoric may be oversimplified. Certainly as with any institution that served as a mouthpiece for the colonial administration, indoctrination of African students to the colonial cause was of utmost importance. Ponty was indeed founded to train high-level 'fonctionnaires' to carry out the colonial mission. However, the list of Ponty alumni that would soon have an active role in nationalist movements and post-Independence politics is too long to overlook. It is clear that Midiohouan is critical of Socé's works as he describes him as a "philosophe humaniste

\footnotetext{
${ }^{23}$ Midiohouan 72 .
} 
coupé des réalités socio-politiques de son temps, poursuivant un rêve coincé entre l'impossible et l'absolu." 24 Karim's rhetoric is undeniably mild compared to more explicitly anti-colonial texts, but Socé's cultural focus from his extensive use of Wolof to his folkloric passages, communicates to readers his respect and admiration for Senegalese culture even when coupled with select criticism. The hierarchical rhetoric that glorifies all things French is not overtly present in Karim, setting it apart from apologist novels like Bakary Diallo's Force-Bonté. ${ }^{25}$

Karim takes place entirely in Senegal between the two coastal cities of Dakar and Saint-Louis. The narrative traces the life of Karim, a young Senegalese man who dreams of becoming a true "samba-linguère" or nobleman, seeking to translate the past glories of traditional Senegalese nobility to his twentieth century life. Frequently using Wolof in his narrative, Socé's prose reflects the linguistic reality of Senegalese society while remaining accessible to the French-reading public. He provides definitions when necessary and defines terms in footnotes. He explains that a "[samba-linguère est] un Noble dans le sens que ce mot avait en France avant 1789, car il y a eu au Sénégal, une aristocratie avant l'arrivée des Français." ${ }^{, 26}$ Using Karim's quest for social status as a framework for his commentary, Socé's story contains criticism and praise for both Senegalese and French culture. Karim's tale is a cautionary one, as Socé's goal is to make readers reevaluate existing cultural values that he finds detrimental to advancement in an increasingly interconnected world. However, it is in these same portraits, that

\footnotetext{
${ }^{24}$ Midiohouan 74.

${ }^{25}$ Bakary Diallo's 1926 novel Force-Bonté, is an autobiographical apologist novel that seeks to outline the goodness and generosity inherent in the French colonial project. The author suggests that France is truly reaching out to Africans with the intent to share and enrich. Particularly influenced by the French ideal of "fraternity," Diallo believes that man should seek to unite in peace and mutual respect and that this is only possible through French intervention.

${ }^{26}$ Ousmane Socé, Karim: Roman sénégalais (Paris: Nouvelles éditions latines, 1948) 23.
} 
readers can discern the author's deep respect for Senegal's unique culture. If France justified its civilizing mission with the belief that Africa was devoid of history and literature, Socé's narrative confronts these subjugating stereotypes by proving their inaccuracy. Like many African languages, Wolof was not written and Senegalese literature was communicated orally and passed down from generation to generation by family members and griots. Socé makes the first step in honoring this oral history and literary tradition by weaving folklore into his narrative, translating it from Wolof into French in an effort to share Africa's unique cultural and literary traditions with a larger Francophone reading public. In Karim, Socé includes a long passage where Aunt Aminata recites a staple of Senegalese folklore, the tale of Leuk-le-lièvre, a character whose adventures Sadji and Senghor will reinterpret several years later. After this scene where Aminata recites the tale to a captive audience in the courtyard of her home, the narrator explains:

Depuis les siècles les plus reculés, grâce à la tradition orale, elles [les femmes qui transmettent la tradition] ont charmé notre jeunesse avec des 'legs' venus du fond du passé. Elles ont voulu nous faire aimer la justice, haïr la malhonnêteté et nous former à la vie en nous léguant leur expérience à l'aide d'une ample comédie' dont la scène est la société noire, avec ses conceptions, ces croyances, les défauts et les qualités de ces hommes noirs. ${ }^{27}$

The character of Karim symbolizes the duality of the colonial situation. Though not an intellectual like his creator, he is a product of the colonial education system. He earned a diploma, completed his military service, and works in an office where he spends his days keeping the books: "il y passait les journées devant de grands registres et additionnait d'interminable colonnes de chiffres. ${ }^{28}$ His life is marked by both the pole France and

\footnotetext{
${ }^{27}$ Socé, Karim 77.

${ }^{28}$ Socé, Karim 18.
} 
the pole Africa, as he is defined by the traditions of his ancestors, his native language and culture, while simultaneously holding a low-level office job.

Though much of the text showcases that which makes Senegalese culture unique, Socé also includes stigmatizing social commentary for which he later has to defend himself in the press. ${ }^{29}$ The primary criticism is centered on Karim's preoccupation with presenting himself as a "samba-linguère" without having the means to do so. He nears financial ruin on several occasions in his attempts to charm the opposite sex by feigning wealth. For Socé, this generation is too preoccupied with material possession and social status and he criticizes Karim's lack of intellectual curiosity and professional drive. The narrator explains that Karim "ne put se résoudre à lire les ouvrages classiques pour compléter son instruction [puisqu'] il avait fait des études pour le profit matériel qu'il pourrait en tirer. Or il avait réalisé son rêve: il était devenu bureaucrate; depuis il avait délaissé les livres."

Through his critical portrait of Karim, Socé communicates a respect for the contributions of the colonial education system that permeates much of his philosophy. Rather than choosing to better himself professionally or academically, Karim is solely preoccupied with wooing Marième: “Ainsi Marième était son unique passe-temps sa seule joie." 31 The narrator explains that "Karim aurait pu, en conservant Marième, préparer les examens et trouver dans l'administration une situation rémunératrice qui lui permettrait de faire face à ses dépenses." This kind of passage is likely a source of the criticism he received after the novel's publication. When taken out of context, Socé is

\footnotetext{
${ }^{29}$ See Ousmane Socé, “Impressions d'Europe," Paris-Dakar 6 Aug. 1937: 2 and Myrau, "Défense de M. Ousmane Socé," Paris-Dakar 29 Oct. 1937: 2.

${ }^{30}$ Socé, Karim 33.

${ }^{31}$ Socé, Karim 33.
} 
associating Karim's salvation not only with the colonial education system, but also with the administration - the only employment that could support his desired lifestyle. In Karim, Socé ignores the excesses and inequalities present in the current system in what seems to be an honest portrait of the financial realities facing colonial subjects. A post in the colonial administration was likely the most lucrative, and to obtain such posts, Africans had to continue their studies beyond a primary school education. For Socé, Karim is living in the past and in doing so, ignoring the new and evolving challenges of $20^{\text {th }}$ century life in Senegal. The narrator exclaims, "Infortuné Samba-Linguère! Il lui fallait, de toute nécessité, reformer son train de vie et l'adapter à sa bourse. Le grand mal, source de ses ennuis, venait de ce qu'il voulait vivre, au vingtième siècle, comme les samba-linguères d'autrefois." He is not necessarily criticizing the historical role of the samba-linguère in Senegalese culture, but its discord with the demands of the life in AOF between the two wars. He continues, "Et c'était une erreur de sa part, parce que, par hérédité, ils lui avaient légué leur générosité, de vouloir mener une existence en désaccord avec les exigences modernes..."32

Though in Mirages de Paris, Socé is explicit in his presentation of cultural métissage, weaving the terms themselves into his narratives, the ideas are presented more subtly in Karim. With little direct reference, Socé is presenting the story of Karim as a cautionary tale exemplifying the relevance and need for cultural métissage in modern Senegalese society. Through his portrayal of Karim, Socé is able to apply the notions of "autocritique" that are central in his philosophy. In his speech, entitled "Impressions d'Europe," that was delivered to a packed crowd at the Dakar Chamber of Commerce on July 31, 1937, Socé acknowledges the criticism he received after writing Karim and

\footnotetext{
${ }^{32}$ Socé, Karim 34.
} 
presents a working definition for his interpretation of cultural métissage, though still without using the term itself:

Et c'est ici que je répondrais à ceux qui nous reprochent d'écrire pour le plaisir de dire du mal de notre pays. Si nous avons écrit Karim entre autres, c'était en quelque sorte pour faire d'abord une anatomie de nousmêmes qui résumerait nos qualités et nos défauts. Nos qualités ; nos amis et les griots nous les répètent souvent mais nos défauts, et c'est tout naturel, personne ne vous en parlera. Il nous faut faire nous-mêmes une autocritique pour les connaître et pour ma part je considère indigne d'un intellectuel de tromper ses compatriotes comme un vulgaire flatteur; je considère comme un acte criminel de la part d'un intellectuel de mentir a ses congénères, de ne pas leur dire la vérité. Commençons par la connaissance de profonde de nous-mêmes, de nos qualités, de nos défauts, de nos forces, de nos faiblesses et de nos véritables aspirations. En un mot, pour le monde nouveau que nous voulons créer, semons avec des graines qui soient non seulement viables sur le sol africain mais aussi des graines dont les produits seront des bienfaits pour le peuple noir. ${ }^{33}$

This event was highly publicized and the speech was published in Paris-Dakar, therefore introducing a larger reading public to his ideas and theories. Followed one month later by a speech in which Senghor presented divergent ideas, Socé's presentation did not receive universal praise. Not only were there several articles in Paris-Dakar addressing the fallout in the following weeks, Socé chose to revisit these unresolved questions in Paris-Dakar in 1939 in a heated exchange with Fily Dabo Sissoko and in Dakar-Jeunes in $1942 .{ }^{34}$ This last iteration of the debate is the most complete of its kind and included the participation of several future prominent literary and political figures including Mamadou Dia and Abdoulaye Sadji, and the third chapter of this study is dedicated to its analysis.

\footnotetext{
${ }^{33}$ Ousmane Socé, “Impressions d'Europe," Paris-Dakar 6 Aug. 1937: 2.

${ }^{34}$ See Appendix for transcripts of Socé's and Sissoko's 1939 publications.
} 
In a series of articles published in Paris-Dakar defending Socé after "Impressions d'Europe," a certain Myrau addresses the novelist's detractors. ${ }^{35}$ He explains:

Quels sont donc ceux qui critiquent Ousmane Socé ? Ils forment deux groupes, deux catégories d'intellectuels : ceux qui sont volontairement aveugles et ceux qui n'ont pas compris Karim. Les premiers moins nombreux, mais plus dangereux peut-être combattent Ousmane parce que dans Karim et dans sa conférence, ce compatriote a flétri certaines de nos mœurs et traditions. Il a trop montré que le griot, le marabout et la femme ruinent la société indigène et entravent son évolution, sa marche vers le bien, vers le beau, vers la vérité. ${ }^{36}$

Though Socé would not likely agree this observation, Myrau does underline the nature of the backlash. In Karim, Socé does not systematically criticize women, the griot tradition, or marabouts, but rather specific elements of society that he feels are no longer in accordance with the current system. To fully understand Karim, one must also consider the passages where the narrator fondly recounts the role of women in the transmission of folklore and oral history, his frequent use of Wolof, as well as references to Senegal's rich heritage. Socé is, for example, highly critical of the limited education available to women as well as the cultural precedence that further hinders them from pursuing an education and a career outside of the home.

In one telling passage, after eating dinner at his Aunt Aminata's home, Karim enters into his cousin Abdoulaye's room, a teacher and graduate of William Ponty. He makes references to the collection of books on his bookshelves and his European style clothing. The narrator suggests that the protagonist feels more comfortable with his younger cousin Ibrahïma who is dressed in a traditional fez and boubou. Observing the

\footnotetext{
${ }^{35}$ Though it is important to understand the criticism that influenced the work of Socé at the time, a more detailed analysis of the criticism in the press after "Impressions d'Europe" will be included in Chapter 3 as they are essential for framing the motivation that pushed Socé to launch the debate on cultural métissage in Dakar-Jeunes.

${ }^{36}$ Myrau, “Défense de M. Ousmane Socé," Paris-Dakar 29 Oct. 1937: 2.
} 
contrast between Africa and Europe, the reader learns "Karim, au moindre détail, sentait des idées et des aspirations différentes des siennes, restées sénéglaises, malgré sa demieculture." This passages ends with Karim summarizing his impressions in Wolof with French translations in an exchange with his more traditional cousin. Karim concludes “Gagni gueum na gnou yeuffi toubab yi di (ils croient beaucoup aux choses d'Europe)!” Ibrahïma responds "Eh! Toubab you nioul la gnou (Eh! ce sont des Européens noirs).",37 Socé presents the full spectrum of métissage with portraits of griots as well as "les Toubabs noirs." This terminology, used to critically describe the educated African elite, suggests a certain schism between those living more traditionally and those who had adopted a more French or European lifestyle. Though Karim fell in the middle of the spectrum, he still valued tradition, viewing these "toubabs noirs" as others. By presenting characters representing the full range of métissage with Abdoulaye embodying a figure of the educated African elite, Socé better communicates the complex choices facing a colonized society. This passage is neither overtly critical nor complimentary of either way of life, but rather exemplifies the cultural alienation that can occur when trying to reconcile two divergent poles of influence. Karim has a primary school education, and the narrator refers to him as being of "demie culture," however Abdoulaye is presented as being on the European side of the colonial cultural spectrum. This passage underlines several key points about the duality of the colonial experience that Socé feels can only be reconciled through cultural métissage. The reader sees here, the varying degrees of possible assimilation from Karim's status as “demie-culture” to Abdoulaye's status of "Européen noir." The author does not explicitly ask his protagonist to choose one side over the other, but rather seeks to inspire his readers to

\footnotetext{
${ }^{37}$ Socé, Karim 72.
} 
acknowledge the need for cultural métissage in African society. This passage, where Karim must confront the manifestation of France's direct influence on Senegalese culture, is directly followed by Aminata's nearly seven-page recitation of traditional folklore that is laced with nostalgia and praise for his homeland.

Socé's novel is as problematic as the colonial situation itself and without being either overtly anti-colonial or exclusively pro-French; the author navigates the complex and oven ambiguous road of living in a bipolar system. For Socé, the only response requires voluntary evolution and the willingness to alter traditional existence to better compliment the realities of life in AOF at the time. It is clear that Socé does not endorse full-scale assimilation and only by considering select passages could that conclusion be made. When examining the novel as a whole, Socé is performing the act of selfcriticism, using the example of Karim to prove his points without overtly taking sides. His prose is simple, but his narrative presents the nuance inherent in a philosophy that couples praise and criticism while negotiating feelings of great pride and even shame. This simplistic style would earn him additional criticism from two of his most well known contemporaries. Midiohouan explains:

Socé eut quelques difficultés à trouver un éditeur pour son premier roman que [Réné] Maran qualifia de "nouvelle mal construite de souffle court et de style incertain." De même, Senghor avoue qu'il "ne peut pardonner à ce docteur-vétérinaire, ancien instituteur, ses nombreuses négligences de style qui témoignent un travail trop hâtif. ${ }^{38}$

Socé's works may be more compelling for their content than style, but he indeed manages to provide a candid portrayal of Senegalese society in the years between the two wars while simultaneously promoting cultural métissage.

${ }^{38}$ Midiohouan 72. 


\section{Mirages de Paris}

Published in 1937, Socé's second novel Mirages de Paris depicts life in Paris, contrasting Karim's unique focus on Senegal. Guy Midiohouan suggests that Mirages de Paris was written while Socé studied in Paris and the novel explores the societal challenges facing young colonial transplants while also providing a rare glimpse into the infamous Exposition coloniale of $1931 .^{39}$ Through his portrayal of Fara, a young African man living in Paris, Socé is able to further enumerate his philosophical platform while demystifying the Parisian experience. ${ }^{40}$ Both cultural and physical métissage are explored as Socé traces the trajectory of Fara from Senegal to France, exploring not only the Exposition but also his protagonist's relationship with a White French woman, Jacqueline. If Socé's judgement of Senegalese culture in Karim incited criticism from his contemporaries, Mirages de Paris' role as a narrative exploration of cultural métissage is more explicit. Socé's illustration of the trials of Parisian life, expressed through Fara's frequent encounters with racism and general ignorance about colonialism and African culture, communicates the real challenges that inspired the socially engaged writings of the decade. Though it is clear that Socé frequented the Negritude cohort, philosophically he remains on the fringe with his ideas focusing less on revalorizing race and more on

\footnotetext{
${ }^{39}$ The "Exposition coloniale de 1931" is often considered the apotheosis of the French colonial myth that was propagated to communicate the country's greatness and the success of the civilizing mission. Charles Ageron, who has written extensively on the subject, explains that "l'Exposition devait provoquer chez le visiteur l'illusion d'un voyage colonial" with colonial subjects being subjugated by spectators' objectifying gaze [Charles-Robert Ageron "L'Exposition coloniale de 1931 : Mythe républicain ou mythe impérial," Lieux de Mémoire, ed. Pierre Nora (Paris : Gallimard, 1997) 574]. The role of the Exposition in Mirages de Paris is worthy of further exploration as Socé devotes entire passages, namely Chapter 3, to describing the event from the iconic recreation of Cambodia's Angkor Wat temple to the small-scale souvenir market Africans ran to earn extra income. Socé writes "le long des allées de la Cité, ils [des amis Africains] avaient installé de petit commerces d'objets fabriqués en Afrique noire. Il y en avait d'authentiques, mais aussi d'origine nord-africaine ou levantine." Ousmane Socé, Mirages de Paris (Paris : Nouvelles éditions latines, 1964) 36.

40 "Si Mirages de Paris fut entièrement écrit en France pendant que l'auteur faisait ses études à l'École de Médecine Vétérinaire de Maisons-Alfort, Karim, par contre, fut en partie écrit en Afrique." Midiouhouan 72.
} 
redefining culture through métissage. His musings in Mirages de Paris center on his conception of an emerging "monde nouveau" whereas Senghor was busy conceptualizing a path for the definition of the "nègre nouveau."41 This juxtaposition of universality and specificity best exemplifies Socé's divergence from the themes that characterized much of the Negritude-inspired writings of the $1930 \mathrm{~s} .{ }^{42}$ Characterized by a return to racial and cultural roots, Negritude focused much less on the kind of open cultural exchange inherent in métissage. Even if Socé, like Césaire, Senghor, and Damas, wrote about the challenges of Parisian life, his primary goal was not the revalorization of race, but the promotion of his own philosophy.

Socé was, however, quick to debunk the Eldorado myth propagated by the colonial education system. ${ }^{43}$ Alice Conklin in her book $A$ Mission to Civilize summarizes this well: "African children were being taught that under France's guiding hand, their home was becoming a more productive, egalitarian, and modern place. The hallmarks of civilization were technological achievements [...] superior morality, and the ability to speak French." ${ }^{\text {44 }}$ Promised a sparkling city full of promise, colonial subjects arriving in Paris were soon slapped with the reality of racism and the difficulties of urban life. Beginning with the rupture experienced when a child abandons his Koranic education for

\footnotetext{
${ }^{41}$ In an essay first published in Présence africaine in 1950 entitled "Le message de Goethe aux nègrenouveaux," Senghor writes "Ce furent, entre 1930 et 1939, les années d'ivresse du Nègre Nouveau en France. Munis des armes miraculeuses de l'écriture automatique, plus furieux que mitrailleuses, nous projetions sagaies empoissonnées et couteaux de jet à sept branches, nous faisions sauter tous les volcans de l'Éthiopie et ensevelissons, le jour de l'Ascension, tous les Saint-Pierre sous la pluie de feu de notre ressentiment. Nous le pensions du moins." Senghor, Liberté I 84.

42 The Negritude cohort included not only Césaire, Damas, and Senghor but members of the Association des étudiants Martiniquais (including the Nardal sisters), the Association des étudiants d'Afrique occidentale (which included both Ousmane Socé and Birago Diop), and those actively participating in the publication of the short-lived journals, "Le cri des Nègres," "Légitime defense," and "L'Étudiant noir."

43 "Les pays d'au-delà les horizons de sa petite patrie exerçaient sur lui une séduction irrésistible. Voir Paris qui, au dire de tous était un El Dorado, Paris, ses beaux monuments, ses spectacles féériques, son élégance, sa vie puissante que l'on admirait au cinéma," Socé, Mirages 15.

${ }^{44}$ Alice Conklin, A Mission to Civilize (Stanford : Stanford University Press, 1997) 136.
} 
a French school, and eventually arriving at the disillusion that Parisian life afforded, Socé traces the unique challenges and contradictions facing educated colonial subjects.

After a passage describing a seemingly idyllic childhood until the age of nine, the narrator explains that Fara's father “avait dit a son fils qu'il le menait à l'école des blancs." Christopher Miller in his article "Hallucinations of France and Africa in the Colonial Exhibition of 1931 and Ousmane Socé's Mirages de Paris” characterizes well the confusing duality of the colonial situation:

The mixing of peoples here has produced an unhealthy desire on the part of the colonized, a state of false consciousness, a cathexis that can never be discharged (though the inevitable attempt will be made by going to Paris). The boy who had been 'free' in mind and body is now enslaved through addiction to the culture of a foreign land. Most importantly, the realm within which Fara has been taught to dwell is a mirage, a hallucination. ${ }^{45}$

Mirages de Paris explores common tropes of Francophone literature as the inevitable encounters with physical and cultural difference spark introspection. The narrator explains that after arriving in Paris "Fara sentait que cette foule blanche l'assimilait mal. Elle n'arrivait à le tolérer qu'à force de bienveillance."46 The French spectators he meets at the Exposition know little to nothing about Senegalese culture and when Fara befriends a group of women “elles avaient des opinions imprévues, pleines d'erreurs en matière coloniale. L'une d'elles avait annoncé que Dakar était la capitale de Madagascar; une autre demandait si les cannibales étaient nombreux à Dakar et Jacqueline croyait qu'on marchait nu au Sénégal."47 Socé acknowledges the seemingly insurmountable challenges of life in the imperial capital as Fara is never able to secure stable employment and

\footnotetext{
${ }^{45}$ Christopher Miller "Hallucinations of France and Africa in the Colonial Exhibition of 1931 and Ousmane Socé’s Mirages de Paris," Paragraph 18.1 (1995) 43-44.

${ }^{46}$ Socé, Mirages 63.

${ }^{47}$ Socé, Mirages 41-42.
} 
Jacqueline's parents do not approve of the biracial union. The novel ends in allegorical tragedy when, after Jacqueline dies in childbirth and her parents decide to adopt the biracial child in an effort of reconciliation, Fara commits suicide in the Seine.

In accordance with his philosophical project and Karim's narrative precedent, Socé weaves both nostalgic praise and cultural criticism into Mirages de Paris. For example, speaking to Jacqueline about his culture, Fara speaks fondly of oral tradition and the role of the griot:

Le joueur de la guitare ne reproduit pas une musique écrite, car la musique n'est pas écrite en pays noir, pas plus que l'histoire et la littérature, et n'importe qui n'est pas musicien ou littérateur; ce sont des castes bien définies qui exercent ces arts, de génération en génération; aussi le font-ils avec un certain mysticisme. L'artiste est un 'initié.' Pour lui, le passé et la vie des ancêtres sont lumineux. Dans les vibrations des cordes de la guitare, il revoit toute l'histoire du pays noirs : conquérants fameux, cataclysmes symboliques, actions d'éclat des héros, tout est ressuscité par la corde qui vibre les événements du passé défilent en procession merveilleuse ! La philosophie même du monde noir devient intelligible ; il vous expliquera pourquoi la bravoure est supérieure à la lâcheté et la vérité au mensonge... ${ }^{48}$

Writing in exile, the nostalgia for his homeland that marks Senghor's first collection of poetry, Chants d'Ombre (1945), is also present in Socé's works. His novelistic writings all include lengthy passages paying homage to Senegalese culture with a particular focus on folklore. ${ }^{49}$ The most profound difference, however, between his writings and those of Senghor, Damas, or Césaire during this period, was the criticism of select African traditions coupled with an openness to and praise of certain aspects of French society and culture. Unlike his well-known contemporaries whose focus on Negritude implied a rejection of assimilation, Socé was unwavering in his promotion of métissage.

\footnotetext{
${ }^{48}$ Socé, Mirages 84-85.

${ }^{49}$ This is something he shares with Abdoulaye Sadji and the role of folklore in the latter's work will be investigated in depth in Chapter 4.
} 
Socé dedicates Chapter 12 of Mirages de Paris to an enumeration of his philosophy, defining cultural métissage through a conversation between Fara and Sidia, an African philosopher and intellectual who Fara deeply admires. Sidia is a prototype of the engaged Negritude thinker. Senegalese and living near the Sorbonne, Sidia, like Senghor, is extremely erudite and fully dedicated to the advancement of his race. When Fara meets with his friend to announce that he will name his child Sidia if born a boy, a debate ensues about physical and cultural métissage. Sidia, like Senghor at the time, was wary of métissage. Though happy for his friend, he immediately communicates his disapproval of Fara's union with a White woman. Sidia explains:

Oui, mais il fallait prendre des précautions pour ne pas avoir d'enfant. Si tu envisages la question d'un point de vue individualiste, il n'y a pas de mal. Seulement la question te dépasse. Elle intéresse notre race et son avenir même. Il ne faut pas que nous, élite noire, nous ayons des enfants métis. Ceux-ci retourneront à la race blanche un jour ou l'autre. Et la race noire qui a tant besoin de cadres, se trouvera écrémée de génération en génération; ainsi elle ne pourra jamais se guérir du mal qui l'étouffe et l'affaiblit $[\ldots] .^{50}$

Sidia's declaration launches a debate that allows Socé to present his views through Fara's pro-métissage arguments. For Fara "le métis sera l'homme de l'avenir" and he cites history as his primary supporting argument. ${ }^{51}$ Socé denies the existence and possibility of a pure race or society and acknowledges the inevitability of France's cultural influence in Africa. Fara explains to Sidia that "tout est métis; il n'y a pas sur la terre une race pure, une civilisation qui ne soit pas métisse." Sidia, who above all seeks to valorize his race is not, according to Fara, "noir cent pour cent, tu es métis avec ta culture européenne! Il a fallu que tu te métisses pour développer ton esprit."

\footnotetext{
${ }^{50}$ Socé, Mirages 146.

${ }^{51}$ See Socé's eventual interest in the works of Cheikh Anta Diop explored later in this chapter.
} 
Socé underlines the complex dilemma facing colonial subjects in general.

Linguistic métissage is unavoidable if trying to communicate a message to a larger

audience. The members of the Negritude cohort represented the best and brightest of the colonial education system and were hugely influenced by European literature, philosophy, science, and technology. While Socé was writing and publishing novels, Senghor was teaching Latin and Greek at the Lycée Descartes in Tours. Therefore, by underlying Sidia's erudition, Fara is able to emphasize the primary domain in which he feels that métissage was already occurring and, more importantly, where it must be fostered for African advancement. Socé is a true believer in the education of the masses, women included, in subjects ranging from science to literature. Likewise, the power of education and Africans' inherent capacity for equal academic and professional success is a common thread in his work, second only to cultural métissage. ${ }^{52}$ Fara explains, "il faudra néanmoins que chacun de nous, en son activité personnelle, soit pénétré d'un esprit nouveau, un esprit qui comprenne les exigences de la vie moderne et s'y adapte.",53 For Socé, adapting requires a critical approach to culture in which elements of each pole of influence are considered. Thoughtful self-criticism or "autocritique" is key to his

\footnotetext{
52 "Vois-tu, Sidia, tout cela n'est ni ta faute ni la sienne. Le tort est à ceux qui n'ont pas voulu éduquer et instruire les Sénégalaises. C'est une lourde erreur dans un pays que de laisser évoluer les hommes de maintenir les femmes dans un état mental et pratique qui ne s'accordent qu'avec le monde de vie de la tribu" Socé, Mirages 150. "Cet état de choses, outre qu'il rend plus difficile l'éducation de la jeunesse, met dans une situation déconcertante l'homme africain qui ne trouve pas de compagne à son image, ou du moins la femme noire devient une force d'inertie contre quoi se heurte et se brise très souvent toute acquisition que l'homme noir a fait en essayant de s'élever dans la voie du progrès. Nous voyons ainsi l'importance que présente l'éducation active de toutes nos femmes quelles que soient leurs confessions religieuses. C'est un problème vital. Si on n'y apportait pas de solution ou bien l'évolution de ce pays serait vouée à l'échec, ou bien notre société de demain ne sera pas un édifice équilibré, à la solidité durable, mais un monstre disproportionné où l'homme sera très mal à l'aise." Ousmane Socé, "Impressions d'Europe" Paris-Dakar 6 Aug. 1937.

${ }^{53}$ Socé, Mirages 179.
} 
philosophy and the primary action through which cultural métissage must occur. ${ }^{54}$ Fara notes: “C'est notre devoir à nous, les jeunes, d'opérer les changements qui s'imposent; nous avons des coutumes charmantes, mais nous en avons d'inutiles." ${ }^{, 55}$ The goal of Karim was indeed to exemplify this point: Socé may admire Africa's rich oral history, the Wolof language, and African community structure, but he criticizes the lack of education for women and a dominant culture that prioritizes wealth (or feigned wealth in the case of Karim) over education and professional advancement.

Again using problematic rhetoric when taken out of context, Socé references the superiority of European civilization in an attempt to further prove the need for métissage in Africa. It is important to note that nowhere does Socé adopt the colonial philosophy used to justify France's civilizing mission that systematically underscored the existence of African civilizations prior to the arrival of Europeans to the continent. He does however, praise Europe's modernity, and believes that Africa, and Africans, must adapt in order to succeed in the new world order:

C'est encore du métissage et le véritable car ce qui fait un homme c'est encore plus sa culture et ses idées que la coloration de sa peau. Or, de nos jours, il se forme en Afrique, comme cela s'est fait chez tous les peuples, à une époque donnée de leur histoire, un véritable accouplement avec un pays plus avancé en civilisation, et d'où naîtra l'Afrique nouvelle. ${ }^{56}$

Socé's philosophy did not focus on the problematic racial hierarchies that defined the French imperial project and this could be his philosophy's weakest point. When compared to the contemporary writings of Senghor or Césaire, his texts seem complacent

\footnotetext{
54 “C'est aux jeunes d'avoir le courage de voir la réalité de ces défauts, en face, sans s'enerver [...] ensuite avoir le sang-froid et lucidité, mais aussi avec entêtement, c'est aux jeunes de détruire les routines entre lesquelles étouffe notre pays" Socé, Mirages 151. Socé dedicates fewer pages to theses detrimental routines in Mirages, whereas in Karim he focuses on the aspects of indigenous culture that he deems incompatible with modern society.

${ }_{55}^{55}$ Socé Mirages 180.

${ }^{56}$ Socé Mirages 148.
} 
to a problematic status quo. The reality of his philosophical outlook, however, is much more nuanced. I believe this is one source of the misunderstanding surrounding his message as well as the simple juxtaposition of a writer presenting a more moderate philosophy when Negritude was becoming increasingly influential. The author of Karim and Mirages de Paris often leaves colonialism out of his rhetoric as if the "monde nouveau" that he imagined was free of the constraints inherent in the current system.

Socé certainly did not write in a bubble and, especially in Mirages de Paris, he seeks to debunk the misleading Eldorado myth propagated in Africa by French schools in favor of an accurate portrait of the challenges of life in the imperial capital. As the title shows, Paris proved to be a mere mirage that led to Fara's ultimate demise. Of he and Jacqueline's relationship, only their offspring will live on, a mixed-race child that will be raised in White household. Is Fara's son's adopted family symbolic of Socé's view of métissage? The writer and veterinarian never advocated eclipsing African culture in favor of a purely European model. He repeatedly called for reform, however, and thus an "esprit nouveau" that is malleable and open to change. For Socé, the future of Africa depends on the willingness of youth to "opérer les changements qui s'imposent" and before his death, Fara claims he is going to return home to spread his ideas: "Il faut que la jeunesse d'aujourd'hui fasse ce travail. Nous devons l'accomplir en songeant aux Sénégalais de demain par devoir de solidarité entre générations. ${ }^{„ 57}$ The focus on the future is omnipresent in passages dedicated to the enumeration of his philosophy. The deaths of Fara and Jacqueline leave readers with a dose of realism that serves to contrast Socé's otherwise utopian philosophical ideals, effectively communicating the harsh

\footnotetext{
${ }^{57}$ Socé Mirages 179-180.
} 
realities facing colonial subjects at the time without presenting a full-scale rejection of the system.

\section{“Impressions d'Europe"}

Though it is unclear exactly when in 1937 Mirages de Paris was published,

Brousseau suspects that Socé started working on the novel as early as $1933 .^{58}$ That same year, Socé had the opportunity to further define and disseminate his philosophical ideas, this time in his homeland. The Foyer-France Sénégal, an organization whose monthly bulletin "L'Afrique Nouvelle" describes their mission as a "Société mutuelle et de solidarité pour le développement de l'Enseignement," frequently hosted talks at the Dakar Chamber of Commerce with topics ranging from prenatal health to culture as seen in the case of Socé and, soon thereafter, Senghor. On July 31, 1937, the Foyer introduced Socé who delivered a speech entitled "Impressions d'Europe." huge success and an article in Paris-Dakar, "La conférence de M. Socé a remporté un succès triomphal à la Chambre de Commerce," described overflow attendance, over 1,500 spectators, and widespread appreciation for the author's message. ${ }^{60}$

Though Socé's and Senghor's names have been juxtaposed throughout this chapter, it is here where their direct dialogue and discord on the subject of cultural métissage first became clear, even if it is known that they traveled in the same circles in Paris and were members of the same student group. ${ }^{61}$ This is, however, a key moment in the evolution traced in this study, as it further solidifies the philosophy presented in

\footnotetext{
${ }^{58}$ Brousseau 177.

${ }^{59}$ See Appendix for full text.

60 “La conférence de M. Socé a remporté un succès triomphal à la Chambre de Commerce," Paris-Dakar 3 Aug. 1937: 1.

${ }^{61}$ Janet Vaillant in her book, Black, French, and African: A Life of Léopold Sédar Senghor, notes that Senghor was the first president of the "Association des étudiants ouest-africains" (founded in Paris in 1933) and Socé served as secretary with Birago Diop also a member. Janet Vaillant, Black, French, and African: A Life of Léopold Sédar Senghor (Cambridge: Harvard University Press, 1990) 99.
} 
Karim and Mirages de Paris, and introduces a clear contrast with Senghor's vision of the future that will be discussed in the following chapter dedicated to his evolving relationship with cultural métissage. In what will be referred to as twin speeches due their thematic similarity, Socé's "Impressions d'Europe" and Senghor's "Le problème culturel en A.O.F" both address the role of African and French culture in West Africa's future social, cultural, and economic development. In many ways Socé's novels are thinly veiled manifestos for his philosophical platform. In "Impressions d'Europe" however, Socé presented his philosophy directly, and the speech's spectators or readers, did not have to extract his ideas from the pages of a narrative.

Senghor served as the president of the conference, introducing his compatriot and friend to the packed auditorium and Paris-Dakar published the complete speech in two installments on August 3 and 6, 1937. The Bulletin Quotidien de la Chambre de Commerce Dakar, which chronicles the Chamber's daily order of business from shipping activity to special events, provides insight into the logistical organization of both Socé's and Senghor's speeches and confirms their enormous popularity. ${ }^{62}$ The following entry from the Bulletin Quotidien suggests that the demand for Socé's speech was higher than the building could accommodate, and though Paris-Dakar published transcripts of "Impressions d'Europe" and "Le problème culturel en A.O.F" in the days following the events, the organizers wanted to print brochures containing both speeches, likely to accommodate those unable to gain entry. Even if the hall could accommodate up to 1,500 spectators, supporting evidence suggests that demand for each event was much higher. Socé's speech was free to the public, but to attend Senghor's conference, tickets

\footnotetext{
${ }^{62}$ Available at the I.F.A.N. "Institut Fondamental d'Afrique Noire” library in Dakar, Senegal.
} 
had to be purchased to cover the printing costs of the proposed brochures and ensure

some order in regulating attendance of the highly publicized event:

Conférence: Sous les auspices du Foyer France Sénégal

Le samedi 4 septembre prochain à 21 heures, dans la Grande Salle de la Chambre de Commerce de Dakar. M. Léopold Sédar Senghor, agrégé de l'Université, professeur au Lycée Descartes à Tours, fera, sous la présidence de Monsieur le Gouverneur des Colonies, Administrateur de la Conscription de Dakar et Dépendances, une conférence sur « Le Problème Culturel en A.O.F. »

Dans le but de couvrir les frais d'impression de cette conférence et celle de M. Ousmane SOCÉ, que nous nous proposons d'éditer en petites brochures, nous nous voyons, pour la première fois, contraint d'établir un droit d'entrée de 5 et 10 francs. Nous nous en excusons auprès du nombreux public qui avait bien voulu nous apporter ses encouragements quand fut donné «Impressions d'Europe. » Nous demeurons fermement convaincus qu'il ne hésitera pas à s'asseoir, une fois de plus, au modeste hommage que nous voulons rendre au mérite et au talent de deux des meilleurs fils de cette terre d'Afrique.

\section{Pour le Conseil d'Administration}

Le Président : Papa Guèye Fall

N.B. Les cartes d'entrée sont en vente à la librairie VIALE et au Foyer France-Sénégal. Pour faciliter l'organisation de la réunion, la vente cessera le samedi 4 septembre, à midi. ${ }^{63}$

"Impressions d'Europe" is one of the clearest presentations of Socé's philosophy

of cultural métissage, although the word "métissage" is surprisingly never used. ${ }^{64} \mathrm{He}$

frames his presentation as a comparison of Senegal and Europe, speaking at length about

the importance of universal education in Africa and the role of both France and Africa in

the execution of this goal. He talks again about the importance of women's education

${ }^{63}$ Bulletin Quotidien de la Chambre de Commerce de Dakar: $2^{\mathrm{e}}$ année no. 3236, samedi le 28 et dimanche le 29 août 1937 (Dakar : IFAN) 2.

64 "Voici quelques jours j'ai accepté de vous entretenir de mes impressions d'Europe. C'est un sujet plein de promesses que j'imaginais attrayant, mais à la réalité c'est un sujet décevant qui n'a présenté d'attraits qu'en un seul de ses aspects, celui des impressions artistiques. Or le but de cette conférence veut que je glisse sur mes impressions esthétiques parce que j'en ai déjà parlé dans un roman et parce qu'aussi elles n'offrent pas beaucoup d'exemples pour nous." [Ousmane Socé, "Impressions d'Europe," Paris-Dakar 3 Aug. 1937: 2] 
and the changes in Senegalese mentality that must take place for reform to occur. For

Socé, this must start at home with parents ready to promote a European-style education, which he believes is essential for his country's evolution. ${ }^{65}$

Towards the end of the speech, Socé outlines the most important aspect of cultural métissage, while addressing criticism he received after Karim for the critical cultural observations directed at his protaganist. As seen in both Karim and Mirages de Paris, the notion of self-criticism or "autocritique" is a primary theme in Socé's writing and the driving force behind his philosophical project. ${ }^{66}$ He acknowledges, until then, having presented Africa as inferior to Europe, namely in terms of education, economic development, and technological advancement, but proceeds to highlight Africa's

65 This is one of the principal points of contention in Socé's and Senghor's education policy. Senghor favored a more hybrid, multi-lingual system that more directly incorporated native languages and culture into the curriculum. Socé explains, "En Europe, le petit enfant qui revient de l'école trouve à la maison des parents qui s'intéressent à ce qu'il a appris dans la journée, l'interrogent sur ce qu'il a fait, rectifient les fausses idées et comblent les lacunes s'il y a lieu, l'obligent à repasser ses leçons et a faire ses devoirs; nul doute que c'est la un rôle de premier plan dans la formation de son cerveau et de sa conscience et cependant ce rôle échappe au contrôle du maitre d'école." [...] "En Afrique à quelque exceptions près, rien de semblable; parti de l'école, nul ne s'intéresse, à la maison, au travail du jeune écolier, personne ne l'incite à travailler, parfois même, s'il aime les études et que, de sa propre initiative, il entreprenne ce travail complémentaire, il se verra dérangé par de parents qui jugent plus utile de l'employer à des occupations où sa faible collaboration n'est pas indispensable. En égard de la masse, l'administration a songé à l'éduquer par la création des cours d'adultes du soir pendant l'année scolaire. Je ne crois pas que ces cours aient attiré, comme ils le devaient, ceux à qui ils étaient destinés ; je me souviens même, dans certaines villes du Sénégal, que s'étaient les jeunes, régulièrement inscrits à l'école du jour, qui revenaient le soir aux cours d'adultes pour s'entrainer à l'examen du certificat d'études. Quel que soit le zèle de l'Administration, pour rendre viable cette institution, il nous semble que l'éducation postscolaire des masses n'aura son effet que si l'élite noir seconde les écoles officielles en créant une ambiance qui sollicite l'adulte de tout âge à prendre gout à la lecture, à réfléchir, à penser, à s'intéresser a tout ce qui se passe autour de lui, de par le monde. Pour y parvenir, il faut encore nous en rapporter à l'exemple européen; il faut une organisation matérielle qui impose à l'homme de la masse la pensée, l'instruction et l'information ; les instruments d'une telle organisation sont les journaux d'information, les revues, les bibliothèques nombreuses et gratuites, le théâtre, le cinéma, les conférences." Ousmane Socé, "Impressions d'Europe," Paris-Dakar 6 Aug. 1937: 2.

${ }^{66}$ Previously quoted: "Commençons par la connaissance de profonde de nous-mêmes, de nos qualités, de nos défauts, de nos forces, de nos faiblesses et de nos véritables aspirations. En un mot, pour le monde nouveau que nous voulons créer, semons avec des graines qui soient non seulement viables sur le sol africain mais aussi des graines dont les produits seront des bienfaits pour le peuple noir." Socé, Mirages 148-9. 
strengths, exemplifying his philosophy in action. ${ }^{67}$ Though he commends Europe's

technological prowess, he claims rapid advancement has led to a moral decline that must be avoided in Africa. African social organization, comprised of deeply spiritual societies steeped in communitarian values, has helped preserve the moral fabric Socé believes is necessary for a fully functioning society. Aspects of European culture should only be mirrored through an African lens, as Socé is by no means calling for a tabula rasa approach to Africa's socioeconomic challenges. He believes the continent already has much of what it needs:

Et c'est ici que l'Afrique prend sa revanche ; pour cette fois, elle se compare avantageusement à l'Europe. Sa vieille sœur commence à s'apercevoir que toutes ses richesses matérielles ne la rendent pas heureuse ; elle s'aperçoit que son bonheur dépendra pour une large part de son perfectionnement moral qu'elle avait négligé dans ses conquêtes effrénées du monde de la matière. L'Afrique, elle, est encore pleine de scepticisme, de religions et d'idéal.

Il nous faut donc, en imitant l'Europe, profiter de la leçon de son expérience, ne commettons pas à notre tout la maladresse de négliger ces grandes forces humaines que sont les valeurs morales. Il nous faut discerner. Il nous faut nous connaitre d'abord avant de construire et ne jamais nous oublier en construisant. ${ }^{68}$

Socé's philosophy of cultural métissage was a moderate approach to the colonial situation that called for compromise and a respect for the strengths and weaknesses of both cultures. In weaving his philosophy into his novels, Socé indeed criticized Senegalese culture, but reserved some of his most eloquent passages for the presentation of the culture and customs of his people. Its not surprising that Socé's subsequent publication,

\footnotetext{
67 “'Tout le long de cette causerie, nous avons comparé l'Europe à l'Afrique, celle-ci jouant toujours le rôle de point inférieur de comparaison. Nous avons proposé tout le long de cet exposé la civilisation économique et technique de la vieille Europe à la jeune Afrique qui est en pleine évolution et qui se demande avec inquiétude dans quel sens elle doit guider sa marche. Nous serions incomplets si nous ne disions pas en même temps à l'Afrique de prendre garde de ne pas copier son modèle sans discernement aucun" [Socé, "Impressions," August 6: 2].

${ }^{68}$ Socé, "Impressions," August 6: 2.
} 
Contes et Légendes d'Afrique noire (1938), was a book of traditional Senegalese tales, again confirming his appreciation of traditional folklore and Senegal's oral history. ${ }^{69}$

Socé concludes by explaining the historical reason for Africa's developmental delays. French imperialism and the civilizing mission were founded on a belief of Africans' racial inferiority that shaped all aspects of colonial policy and ensured the racial hierarchies necessary for France to maintain control of its subjects. Socé does not espouse these beliefs but rather attributes the continents' developmental disparity to geography claiming that 'L'Afrique n'est pas en retard parce qu'elle est l'Afrique, elle l'est parce qu'elle n'a pas été ouverte en même temps que la France, l'Angleterre ou l'Allemagne aux grands courants de civilisation venus d'Orient, la Grèce, Rome et ce qui ont pris la voie méditerranéenne. Son retard est donc 'un vice de date' qui disparaîtra avec le temps."70

\section{"Karim: 1943"}

Serial short stories and articles were common in the West African press and French and African writers published articles, novellas, or folklore that would appear in installments over the course of several weeks, promoting increased readership with the promise of resolution only through the purchase of more newspapers or magazines. Ousmane Socé's “Impressions d'Europe” was published in two parts and Senghor's "Le problème culturel en A.O.F.," in four installments. Socé would also use this format in Bingo, the monthly magazine he founded in 1953 and edited, with such titles as "En lisant Cheikh Anta Diop" and "En lisant Maurice Delafosse" (1956). The third chapter of this study is dedicated to the revue Dakar-Jeunes, but Socé's secondary contribution to

\footnotetext{
${ }^{69}$ He publishes a second edition in 1948 that is included in the $3^{\text {rd }}$ edition of Karim. He adds one additional tale "Tanor, le dernier samba-linguèrte" (Brousseau, 231).

${ }^{70}$ Socé, "Impressions," August 6: 2.
} 
the publication, a serial short story entitled "Karim 1942," merits attention in this discussion of his philosophical evolution. ${ }^{71}$ Published across seven issues between February 26, 1942 and December 31, 1942, Socé, in the first person, tells of his latest encounter with Karim, 10 years after the interactions that inspired the novel. ${ }^{72}$ Socé walks readers through this encounter, quickly inserting his philosophical rhetoric into a dominant narrative focusing on culture. Again representative of his style, in which he weaves philosophy into a primary narrative, the cultural aspect of this story takes center stage as he only explicitly addresses cultural métissage in the first three installments. The rest was primarily dedicated to a description of an outing that he and Karim take to "les arènes sénégalaises" to watch, what is to this day Senegal's most prized national sport, "la lutte" or traditional wrestling. He weaves Wolof into his narrative, confirming his respect for the role of griots in African oral tradition, using the terms 'history' and 'literature' to describe their important societal and cultural role. He explains that "La société africaine, dans sa masse et dans son ensemble, sera toujours ce que ce griot veut qu'elle soit. Dépositaire de tout le patrimoine du passé, littérature, musique, danses, histoire de légendes $[\ldots]$ et coutumes." ${ }^{, 73}$ For Socé, the oral nature of Senegalese literature did not make it obsolete and the frequency of its presence in his writing validates not only his admiration, but also the underlying mission to propagate folklore and oral history through its translation into French.

\footnotetext{
${ }^{71}$ The primary interest being the discussion on cultural métissage he launched on January 29, 1942 with "L'évolution culturelle de l'A.O.F.," an article in which he explicitly reprised the debate that occured after he and Senghor's twin speeches were delivered, and subsequently published, in 1937.

72 “J'ai rencontré Karim dix ans après l'avoir quitté. Nous avons repris contact autour d'un tam tam nuptial, chargé de parfums, doré de bijoux, coloré de toilettes bigarrées, aussi rich et aussi éblouissant que ceux que nous avons admiré ensemble à N'Dar (Saint-Louis) aux beaux jours du Samba-Linguère." Ousmane Socé Dakar-Jeunes “Karim 1942,” Dakar-Jeunes 26 Feb. 1942: 3.

${ }^{73}$ Ousmane Socé Dakar-Jeunes “Karim 1942,” Dakar-Jeunes, 2 Apr. 1942: 2.
} 
As for Socé's philosophical rhetoric, the omnipresent message inherent in cultural métissage appears in the third paragraph of the first installment of "Karim 1942" when Socé informs readers that Karim heeded Socé's criticism and evolved. Socé explains:

Portant Karim a évolué. Aux environs de 1930, c'était la majeure partie de tout une jeunesse qui, au sortir de l'école, n'avait qu'un désir, se conduire dignement en Samba-linguère chez toutes les Marièmes. De nos jours, les horizons de Karim se sont sensiblement élargis. Il s'intéresse aux questions sérieuses; il tente d'organiser sa vie selon les exigences modernes et selon ses nouvelles aspirations. Il croit à sa contribution nécessaire au progrès social par exemple de sa vie et l'éducation de ses enfants. [...] Il prend conscience de lui-même et sa vie universelle. ${ }^{74,}$

He updates readers on Karim and Marième, their children and even responds to Karim who chides the author when he says 'Je t'en ai voulu un peu d'avoir livré au public les ébats de notre jeunesse, tu ne devais pas dire ces choses-là."75 Socé explains that it was important to warn others of the dangers of living outside their means and that Karim should be commended for his considerable progress.

The criticism Socé received for his message continued to be evident and a recurrent desire to justify and better define his philosophy was a common theme in his publications on the subject between 1937 and 1942. In the serial's third installment, this takes the form of a dialogue when Karim's friend Massaër, a farmer from Tiaroye-surMer says “Ah c'est toi Ousmane Socé; tu as écrit dernièrement qu'il faut que nous devenions tous des toubabs?" Socé quickly adds, "Décontenancé je ne sus d'abord que répondre. Je restai bouche bée. Au bout d'un moment je parvins à répliquer."76 This brief exchange is telling of the nature of the criticism he continued to receive though his response to Massaër's claims can again suggest a possible source for the

\footnotetext{
${ }^{74}$ Socé "Karim 1942," 26 Feb. 1942: 3.

75 Ousmane Socé Dakar-Jeunes “Karim 1942,” Dakar-Jeunes, 2 Apr. 1942: 2.

76 Ousmane Socé, “Karim 1942,” Dakar-Jeunes 7 May 1942: 3.
} 
misunderstanding surrounding his message. When considering his body of work and even any single work on its own, it is clear that Socé is not promoting the creation of a class of "toubabs à peau noire." It is important to note that "Karim 1942" is dedicated almost wholly to extolling Senegalese culture: specifically traditional wrestling, which is one the country's most prized traditions. He describes the sport, writing that "tout le monde sait que la lutte est le sport sénégalais le plus passionnant et le mieux prisé."77 His rebuttal to Massaër's claims, however, seems to justify the colonial hierarchy that many fellow Africans had started to reject actively at this time. Though Socé had always been quick to admit that reversing Africa's scientific and technological delay was essential for advancement, his presentation of France's primacy on these fronts again uses rhetoric that may shed light onto his works' controversial reception and the frequent backlash he addresses in associated texts. ${ }^{78}$

J'ai dit, Massaër, que le cultivateur, l'ouvrier, la ménagère comme l'homme de savoir doivent se débarrasser des routines de travail qui les mettent en infériorité vis-à-vis des réalisations de la technique des pays civilisés. Ils doivent profiter de tout ce que la France, par ses écoles, nous offre des possibilités pour mieux cultiver la terre, mieux travailler le bois et le fer, mieux élever le bétail, mieux arranger une maison, mieux s'instruire pour former les cadres immédiats qui doivent servir et guider la masse des artisans et des ouvriers dans leurs diverses activités. La France vous offre une nouvelle vie et une organisation sociale qui dépasse la tribu; elles englobent dans une communauté supérieure des Noirs de différents pays et de différentes races; elles englobent même blancs et noirs dans une patrie supérieure qui s'appelle la Nation. Car Massaër tu sais bien que c'est l'union qui fait la force, la force des blancs comme celle des noirs.

Common assimilationist tropes are present and France's strengths reiterated while Socé explains one side of cultural métissage's inherent compromise, in efforts to refute

\footnotetext{
${ }^{77}$ Ousmane Socé, “Karim 1942,” Dakar-Jeunes 11 Jun. 1942: 3.

78 In addition to "Karim 1942," see "Impressions d'Europe": "Et c'est ici que je répondrais à ceux qui nous reprochent d'écrire pour le plaisir de dire du mal de notre pays," and "L'Évolution culturel en A.O.F."
} 
Massaër's allegations. However, by suggesting that France is civilized in contrast with

Africa and placing all hopes of advancement in the hands of French intervention, he supports the claims of his critics. He completes this installment with what appears to be a summary of the values of the newly reformed colonial association policies promoted before and during the war, reassuring the farmer that he will be able to continue to live a traditional lifestyle, only with more tools to succeed and be profitable. With the exception of an elite few in mostly urban areas, education in the countryside was focused on promoting a traditional lifestyle. ${ }^{79}$ Socé explains that "l'école française professionnelle apprendra à l'enfant à continuer autant que possible, le métier de ses parents, dans le cadre familial, en lui donnant un apprentissage rationnel et élargi de son métier traditionnel." 80 Only when read alone do these citations, however, communicate the purely assimilationist values attributed to Socé. When considered as a part of a greater whole, this message does not fully undermine his touted philosophy, but rather expresses the need for the selective assimilation of French culture and values that defined métissage for Socé.

The last four installments of the short story follow Karim and Socé who attend a match to watch the great wrestling champion, Abdourahmane, fight in what can only be

\footnotetext{
${ }^{79}$ This is a large part of the reformed rhetoric during Vichy's control of AOF as well as the result of the institution of l'École rurale poplulaire in 1934. Pétain and the Vichy government's revised credo "Travail, Famille, Patrie" called for a return to the earth and agricultural production both in France and its colonies. Though this can be seen as yet another glass ceiling to ensure colonial subjugation, this was looked upon favorably by some in AOF as it suggested a higher respect for the traditions that many where trying to preserve, promote, and legitimize through other means (Négritude and nationalism). The way in which this policy change allowed for the creation of a publication as seemingly provocative as Dakar-Jeunes will be investigated at length in Chapter 3. Also for the most complete historical analysis of this complex period in the history of French West Africa, see Ruth Ginio, French Colonialism Unmasked: The Vichy Years in French West Africa (Lincoln: University of Nebraska Press, 2006). For more information on l'École rurale populaire, see Chapter 2 as well as Senghor's article from "Le congrès international de l'évolution culturelle des peuples coloniaux," "La résistance de la bourgeoisie sénégalaise à l'école rurale populaire" found in the Appendix.

${ }^{80}$ Socé "Karim 1942," 7 May 1942: 3
} 
described as a spectacle full of culturally significant ritual and drama. Almost entirely void of the rhetoric seen in the first three parts, Socé shifts his focus from métissage to the match, describing the traditional pomp and pageantry of Senegalese wresting from the chanting to the ritual clothing and ceremonies. ${ }^{81}$ Clearly a fan of the sport, Socé's tone is that of admiration as he praises the unifying power of a national pastime that appeals to all citizens regardless of education or social status. Again the universalism he preaches appears as he describes Abdourahmane's victory in depth, including the traditional Wolof chants that accompany the fanfare along with their French translations.

The stark juxtaposition of the two principal messages of "Karim 1942," and thus the appreciation of both French and Senegalese contributions to society, adds to the sometimes enigmatic and conflicting nature of Socé's philosophy. This duality is, however, a defining characteristic of Socé's conception of cultural métissage. Just as he praises the culture of his homeland, he openly acknowledges France's positive contributions to African society, with a particular focus on education. And although there are aspects of Senegalese culture that Socé vocally deemed detrimental to African advancement, the love of his country is omnipresent in his writing. Always looking towards the future, Socé thought that Africa's success resided in métissage and thus the foundation of a "monde nouveau," a new Africa that kept much of the old while adopting the new that was necessary to compete in an evolving and increasingly interconnected world.

\footnotetext{
${ }^{81}$ I had opportunity to attend such a match in Dakar in January 2011 and barring the sponsorship from mobile phone giants like 'Orange,' the experience Socé describes in 1942 is very much the same as the one I witnessed at Le Stade Demba Diop between champion fighters Yékini and Bombardier.
} 


\section{Bingo and Chiekh Anta Diop}

I have shown that the tenets of cultural métissage permeate nearly all of Socé's works, and the magazine Bingo was no exception to this rule. A monthly publication that at first glance seems to be the African prototype of Paris-Match, Bingo is yet another product of Socé's vision. A beautifully illustrated monthly publication founded in 1953, Bingo: L'illustré africain is described as the "Revue mensuelle de l'activité noire." Socé was the magazine's founder, longtime director, and frequent contributor. The magazine was multifaceted in its subject matter with both literary and cultural content, current events, art, as well as exposés on fashion and even the occasional marriage announcement. Bingo clearly targeted an African audience: the cover art always featured an African subject and the content focused very little on France's role in African affairs and more on Africans' professional and economic successes, exemplifying the kind of proactive evolution Socé so often called for. The magazine, like Socé's writings, couples this focus on progress and Africa's future with a respect for the past and traditional culture. Folklore frequently graced the magazine's pages and several articles are dedicated to African history with titles from 'L'empire Toucouleur d'El Hadj Omar" to "La plus vieille dynastie du monde est africaine: Elle règne toujours en Ethiopie." $\$ 2$ Contributions from Bernard Dadié, Réné Maran, and frequently Socé himself reflect a literary focus that complemented the publication's cultural content. Likewise, Socé uses the pages of Bingo to promote the many social platforms he presented when previously defining cultural métissage. Articles praising women's advancement were common, and the publication seemed to place equal value on male and female readership. Features

\footnotetext{
${ }^{82}$ M.H. "La plus vieille dynastie du monde est africaine: Elle règne toujours en Ethiopie," Bingo Feb. 1960: 14 ; “L’empire toucouleur d'El Hadj Omar” Bingo May 1958: 11.
} 
with titles such as "Fille du Vice Président du government de la Haute Volta, Mlle Denise Ouezzin est à 17 ans et demi la première femme pilote de l'A.O.F.," "Licenciée en Droit en Juin, Mme Diop Ousmane Socé sera-t-elle bientôt la première avocate africaine d'A.O.F.", and "Madame Ouezzin Coulibaly première femme africaine à devenir ministre" sought to show that women could access careers thought to be limited to men. ${ }^{83}$ Bingo's pages were not dedicated to the African embodiment of French taste but portrayed the full gamut of possible style and traditional dress, openly promoting African standards of beauty. If Bingo embodied his vision of métissage, Socé was advocating for gender and racial equality, increased opportunities for professional advancement, meaningful literary production, and the valorization of African culture.

Socé's rejection of Massaër's assimilationist allegations in “Karim 1942” was again supported through Bingo's content and suggested philosophical message. In addition to the cultural focus that characterized his works, Socé frequently used history to refute the civilizing mission's primary justification: the duty to bring the light of French civilization to Africa's primitive masses. ${ }^{84}$ Socé's approach to métissage always included three principal elements: description and praise of Senegalese culture, critique of Senegalese culture, and the presentation of European values that could promote African development. In Bingo, however, Socé chose to focus less on the cultural criticism characteristic of Karim, Mirages de Paris, or even "Karim 1942" and more on the

\footnotetext{
${ }^{83}$ J.H. Thibault, "Fille du Vice Président du government de la Haute Volta, Mlle Denise Ouezzin est à 17 ans et demi la première femme pilote de l'A.O.F.," Bingo July 1958 no. 66: 9. ; "Licenciée en Droit en Juin, Mme Diop Ousmane Socé sera-t-elle bientôt la première avocate africaine d'A.O.F." Bingo Sept. 1958: 3; Jean Dodo, "Madame Ouezzin Coulibaly première femme africaine à devenir ministre" Bingo Dec. 1958: 7-8.å

${ }^{84}$ Socé would likely agree with one point that Fily Dabo Sissako made at "Le congrès international de l'évolution culturelle des peuples coloniaux" and therefore when he cited the only tangible element missing when comparing Africa to Europe: "Qu'a-t-il donc manqué aux Nègres? - L'écriture, tout simplement." Fily Dabo Sissoko "Les noirs et la culture" Le congrès international de l'évolution culturelle des peuples coloniaux: Rapports et compte rendu (Paris: Bibliothèque nationale imprimés, 1938) 117.
} 
enumeration of Africa's strengths, using history as a primary source of praise. Though as early as "Impressions d'Europe," Socé used historical references to disprove claims of racial inferiority, Bingo further confirms Socé's rejection of colonial revisionism.

Beginning in the December 1955 issue, Socé published a long-running summary and analysis entitled, "Nations, Nègres et Culture: En lisant Cheikh Anta Diop." ${ }^{, 85}$ In this detailed exposé on Anta Diop's seminal work, Socé introduces his readers to the Egyptologist's influential research that traces Black African cultural heritage to ancient Egypt, thus disproving claims that discounted the existence of civilization in Africa. Socé explains: "Pour Cheikh Anta Diop les égyptologues modernes ont falsifié l'histoire en attribuant la paternité de la civilisation égyptienne à une race blanche pharaonique qui, du Delta aurait conquis et civilisé la Haute Egypte, l’Egypte noire.” ${ }^{` 86}$ Clearly passionate about the revelatory proof of the Black origins of modern civilization, Socé announces his goals for the lengthy piece as well as his admiration of Anta Diop's project:

Voici un livre qui bousculera vivement des préjugés et même des doctrines étayées sur des études dont les auteurs ont une autorité officiellement consacrée. Le premier mérite de Cheikh Anta Diop est d'avoir le courage et la lucidité de dégager sa pensée de la gangue où des siècles durant, les émules de Levy Bruhl et de Gobineau ont enfermé l'esprit des chercheurs. Sous l'écran de ces œillères l'on avait perdu de vue la préexistence d'une Égypte nègre ayant civilisé la terre.

The proof of "une Égypte nègre, mère de la civilisation" is the ultimate justification for the need to preserve Africa's cultural and linguistic heritage and end racial subjugation. Socé's detailed portrait of Anta Diop's findings, published over at least 8 months, communicates the value he placed on this research that directly linked Sub-Saharan

\footnotetext{
${ }^{85}$ Socé published monthly installments through at least August 1956. Unfortunately the collections of Bingo at both the ANS and IFAN in Dakar are incomplete and only have issues from January - July 1956. The July issue includes "Nations, Nègres et Culture: En lisant Cheikh Anta Diop" informing readers that it was still "à suivre" but the official conclusion was not found.

${ }^{86}$ Ousmane Socé “Nations, Nègres et Culture: En lisant Cheikh Anta Diop” Bingo Jan. 1956 : 9.
} 
Africa to ancient Egypt. Anta Diop's linguistic, social, and cultural observations serve as convincing proof of Africa's historical and cultural legitimacy: ${ }^{87}$

L'absence du papyrus dans certaines régions citées a contribué à la raréfaction de l'écriture au cœur du continent, sans que celle-ci ait jamais été absente en Afrique Noire comme on l'affirme solennellement. A Diourbel, chef-lieu du Cercle du Baol, au Sénégal, dans le quartier de Ndounka, non loin de la voie ferrée, non loin de la route de Daru Mousti, on trouve un baobab couvert de hiéroglyphes, depuis le tronc jusqu'aux branches. ${ }^{88}$

Addressing writing, Anta Diop disproves one of the civilizing mission's classic justifications.

Therefore, armed with convincing ethnological proof, Socé argues that Africans should free themselves from lingering complexes of inferiority that are also stalling progress on the continent. Socé's consistent support for education is linked to his belief of Africans' ability to achieve the same academic and technological prowess as Europe, if given time and the necessary tools. He believes, therefore, that this information should not only serve as a source of pride, but as a mandate for action. He explains:

On ne saurait affirmer avec plus de netteté l'identité de la culture égyptienne et de la culture nègre. C'est en raison de cette identité essentielle de génie, de culture et de race que tous les Nègres peuvent, aujourd'hui légitimement rattacher leur culture à l'Égypte antique et bâtir une culture moderne à partir de cette base. C'est un contact dynamique, moderne avec l'antiquité égyptienne qui permettra aux Nègres de découvrir chaque jour davantage la parenté intime de tous les Noirs du continent avec la Vallée mère du Nil. C'est par ce contact dynamique que le Nègre arrivera à la conviction profonde que ces temples, ces forêts de colonnes, ces pyramides, ces colosses, ces bas-reliefs, ces mathématiques,

\footnotetext{
${ }^{87}$ Ousmane Socé “Nations, Nègres et Culture: En lisant Cheikh Anta Diop” Bingo Apr. 1956 : 3.

88 "Vient ensuite une étude comparative des grammaires égyptienne et valaf (oulof). L'Égyptien dont il est question est la langue classique même c'est-à-dire celle écrite de la IXe à la XVIIIe dynastie, entre 2400 et 750 avant J.-C. J'ai tire les exemples de grammaire valaf de ce que je sais de cette langue qui est la mienne. Cheikh Anta Diop démontre la similitude entre les syntaxes égyptiennes et Valaf (même procédé de formation du pluriel en "ou”). Il fait ensuite une longue étude des lexiques. C'est la partie la plus impressionnante de son étude pour qui connaît le "ouolof" car il y a là des centaines de mots qui sont identiques dans les deux langues” Bingo Feb. 1956: 9.
} 
cette médecine, toute cette science sont bien l'œuvre de ses ancêtres et qu'il a le droit et le devoir de s'y reconnaître totalement. ${ }^{89}$

Establishing this link supports the progress he hopes the continent can achieve through métissage, justifying his desire for both technological advancement and the preservation of African cultural authenticity. Anta Diop calls into question the strict binary opposition of Western civilization and African primitivism by tracing the very elements used to prove the continent's delay to this celebrated ancient civilization.

Acknowledging the cultural alienation caused by misinformation and false history propagated by European scholars, Socé also references the Negritude movement's inability to combat such subjugation as effectively as Cheikh Anta Diop, citing both Senghor and Césaire in his analysis. ${ }^{90}$ He explains, "le plus singulier aspect de cette aliénation culturelle est que des intellectuels noirs authentiques, dans un effort désespéré d'analyse pour plonger aux racines profondes de la culture nègre n'ont pas pu débarrasser de ce complexe. Ils en sont réduits à exhaler avec amertune leur gêne devant cet 'axiome' intellectuel. Écoutons plutôt Cheikh Anta Diop [...]."91 Anta Diop's work, again supporting the value Socé placed on erudition and academic study, was able to present tangible historical facts disproving persistent subjugating views. For Socé, this proof was a much more effective way of promoting cultural and racial valorization, succeeding where Negritude's literary focus failed. ${ }^{92}$ This confirms the philosophical

\footnotetext{
${ }^{89}$ Socé “[...] En lisant Cheikh Anta Diop,” Bingo Feb. 1956: 6.

90 "Pour Cheikh Anta Diop, les égyptologues modernes ont falsifié l'histoire en attribuant la paternité de la civilisation égyptienne à une race blanche pharaonique qui, du Delta aurait conquis et civilisé la Haute Égypte, l'Égypte noire. Cheikh Anta Diop ajoute que la race noire est "le plus ancien guide de l'humanité dans la voie de la civilisation." A preuve: "le Sphinx à tête de nègre et image du Pharaon qui s'impose aux regards de tous." Bingo Jan. 1956: 7.

${ }^{91}$ Socé “[...] En lisant Cheikh Anta Diop" Bingo Dec. 1955: 5.

92 "Écoutons plutôt Cheikh Anta Diop: "Il est fréquent que des Nègres d'une haute intellectualité restent victimes de cette aliénation au point de chercher de bonne foi à codifier ces idées nazies d'une prétendue dualité du Nègre sensible et émotif, créateur d'art et du Blanc, fait surtout de rationalité." C'est ainsi que
} 
distance between Socé and Negritude thinkers while simultaneously exemplifying Socé's espousal of many like values: it was in its execution and scope that his philosophy differed from that of the Negritude cohort. Socé's project indeed included a measured acceptance of select French values from Western education, technology, and science, to the education of women. This departure from the more strict policy of racial valorization that was essential in early Negritude writing established Socé's place on the philosophical fringe at the time. However, to cite Mamadou Dia again, Socé never promoted "l'assimilation complète," as his interpretation of cultural métissage was defined as much by his love and respect for African culture as it was by his desire for cultural evolution and technological advancement.

\section{Conclusion}

Ousmane Socé was one of the first in French West Africa to explicitly define and propagate the philosophy of cultural métissage. Life in AOF was strongly influenced by an uninvited ruler whose mission included the cultural and linguistic indoctrination of its subjects, and it was impossible for many of those living in the system to ignore the

s'exprime de bonne foi un poète nègre dans un vers d'un admirable beauté: "L'émotion est nègre et la raison hellène." Ainsi s'est créé peu à peu une littérature nègre de complémentarité, se voulant enfantine, puérile, bon enfant, passive, résignée, pleurnicharde. C'est ainsi que l'ensemble des créations artistiques nègres actuelles fort appréciées par les Occidentaux, n'en constitue pas moins un miroir où des derniers peuvent contempler avec fierté tout en se laissant aller à une sensibilité paternaliste, ce qu'ils croient être leur supériorité. Les réactions seraient tout autres si les mêmes juges étaient en présence d'une œuvre nègre parfaitement réussie mais qui, sortant de ce cadre en rompant avec les réflexes de subordination, et les complexes d'infériorité, se placerait naturellement sur un plan d'égalité. Une telle œuvre risquerait fort bien d'apparaître comme prétentieuse et pour le moins exaspérante, intolérable pour certains. Le souvenir de l'esclavage récent dont la race nègre a été l'objet, savamment entretenu dans la mémoire des hommes et en particulier dans celles des nègres, affecte souvent la conscience de ces derniers d'une manière négative. A partir de cet esclavage récent on s'est efforcé de construire, en dépit de toute vérité historique évidemment, la légende selon laquelle le nègre a toujours été réduit en esclavage par les races blanches supérieures avec lesquelles il a vécu, où que ce soit, ce qui permet de justifier aisément la présence de nègres en Egypte ou en Mésopotamie, ou en Arabie, dès la plus haute antiquité, en décrétant qu'ils étaient des esclaves. Bien qu'une telle affirmation ne soit qu'un dogme, destiné à falsifier l'histoire et dont la fausseté n'échappe pas à ceux qui l'avancent elle n'en contribue pas moins à aliéner la conscience nègre. C'est ainsi qu'un grand poète nègre, le plus grand peut-être de notre temps, Aimé Césaire (Soleil, Cou Coupé, p. 66) écrit dans un poème intitulé : DEPUIS AKKAD, DEPUIS ELAM, DEPUIS SUMER.” Ousmane Socé "Nations, Nègres et Culture: En lisant Cheikh Anta Diop" Bingo Dec. 1955 : 5, 7. 
effects of the resulting culture clash. The writers and thinkers of Socé's time were born in an AOF already under colonial rule and their lives were undeniably marked by this presence, especially from the time they entered into a French colonial school as children. This moment, where the future duality of their existence was the most striking, would come to be a central trope in African literature, symbolizing a time of trauma, confusion, and existential questioning. For Socé, the colonial education system represented more of a place of possibility than angst, and its core curriculum (colonial propaganda aside) was France's greatest contribution to its Empire. When defining cultural métissage in “Impressions d'Europe," he explains that “l’Europe est arrivée à une apogée du développement technique et économique," but "le progrès moral n'a pas suivi le progrès technique," exemplifying once again the give-and-take rhetoric associated with his version of cultural métissage. The notion of Africa being "morally superior," a broad designation that seemed to embody not just morality, but an overarching support for African cultural and social structure, is clearly exemplified in Karim through Aminata and her eloquent storytelling as well as in Mirages de Paris and "Karim 1942." He explains the formative purpose of folklore: the bedrock of African society and oral tradition through which traditional values are transmitted. The women and men in charge of its transmission held a sacred role in society; they were charged with the moral education of their people. Socé explains that "elles ont voulu nous faire aimer la justice, haïr la malhonnêteté et nous former à la vie."93

Socé must always be considered when referencing this philosophy that continues to be reinvented in a post-colonial world. Socé was steady in his support for this theory that he thought was the only effective response to the colonial situation. Unlike Senghor

\footnotetext{
${ }^{93}$ Socé, Karim 77.
} 
who slowly evolved toward the acceptance and even adoption of cultural métissage, Socé was resolute. His writings all hearken back to this philosophy while presenting his views in different lights and from different angles over time. From Karim to his essay on Cheikh Anta Diop in Bingo, readers can always find cultural métissage woven into his prose. The importance of Socé's role in this dynamic period of African history, from the 1930s to his death a decade after Senegal's Independence, should not be overlooked. He deserves a lasting place among the greats of Francophone African literature, as an innovator whose writing provides one of the most telling perspectives available of the problematic negotiation of culture that inevitably defined colonial subjects' lives. 


\section{Chapter 2}

\section{From Negritude to "La Civilisation de l'Universel:" The Evolution of Léopold Sédar Senghor}

Mais nous, jeunes intellectuels d'Afrique - et j'attache à ce mot plus de devoirs que de prétentions - quand nous traitons de problèmes sociaux et culturels, nous mordons en plein réel, comme dans un "sang " fumant. L'Afrique est grosse d'un monde nouveau, nous en sentons trop le lourd poids en nous pour rêver à autre chose. Il est vrai que nous ne cherchons par la vérité de tel parti, encore que nous sachions juger les partis et les distinguer. La vérité que nous cherchons est plus réelle et plus humaine. ${ }^{l}$

Léopold Sédar Senghor, 1937

Léopold Sédar Senghor is known for his embrace of cultural métissage and is often considered the philosophy's most vocal proponent. However, such claims overlook early writings that tell the story of a thinker who was wary of espousing a credo that would dilute the nascent tenets of Negritude. In the 1930s, I have shown that it was Ousmane Socé who sought to define and promote cultural métissage when Senghor was focusing on racial valorization and promoting African cultural authenticity. Though Socé was steady in his beliefs throughout his lifetime, building on the principles he first presented in Karim: Roman sénégalais in 1935, Senghor exhibits a more distinct evolution, arriving more cautiously towards his eventual acceptance of the philosophy. Unlike his compatriot, Senghor first opted for a more rigid interpretation of Negritude that required him to focus on cultural and racial distinction before considering the selective assimilation of French culture and values that defined Socé's interpretation of métissage. This study will trace Senghor's philosophical evolution, focusing primarily on the 1930s, to understand how and why his views on cultural métissage changed over time. Senghor and Socé were among the most vocal proponents for change in AOF,

\footnotetext{
${ }^{1}$ Léopold Sédar Senghor, “Fidélité des intellectuels," Paris-Dakar 13 Feb.1937: 2.
} 
however they envisioned Africa's cultural evolution differently, promoting divergent plans that sparked intense debate well into the war years.

The promotion of cultural métissage that marked Senghor's later work has served to overshadow his early resistance to the concept. It was Socé, rather, who first preached that métissage was the solution to Africa's cultural dilemma while Senghor remained in the opposing camp. ${ }^{2}$ Though much of this chapter will focus on dynamic exchange of ideas that was occurring in AOF in the 1930s, a brief exploration of Senghor's later thought will demonstrate the eventual embrace of cultural métissage that has come to define his career. Even if hints of an acceptance of cultural métissage appear in his earliest works, Senghor does not officially begin promoting "la Civilisation de l'Universel," and thus his ultimate interpretation of the philosophy, until the late 1950s. ${ }^{3}$ Most of his writings on the subject, inspired by the Jesuit priest and philosopher Pierre Teilhard de Chardin's theory of the same name, do not appear until after Senegal's Independence. Based on the utopian notion of "une civilisation planétaire," "la Civilisation de l'Universel" praises cultural métissage on a global scale, such that all cultures, nations, and civilizations meet, exchange, and mutually progress through egalitarian cultural and intellectual exchange.

To understand the Senghor of the 1930s, it is important to situate his writings in terms of his personal, professional, and philosophical evolution. To cite Wendall JeanPierre in The Harlem Renaissance: Revaluations, "Senghor's concept of Negritude in his more mature years [..] and his progressive elaboration of it during that period, are quite

\footnotetext{
${ }^{2}$ Fily Dabo Sissoko is also cited as having vocally disagreed with Socé on the questions of cultural métissage. In Dakar-Jeunes, Socé mentions both Senghor and Socé as being "anti-assimilationist." Ousmane Socé, "L'évolution culturelle de l'A.O.F." Ousmane Socé, Dakar-Jeunes 29 Jan. 1942: 2.

${ }^{3}$ Senghor uses the term in "Le langage intégral des nègros-africains," preface for L'Anthologie de la Vie africaine published in 1958. The preface can be found in Liberté I.
} 
different from the Negritude he espoused in the 1930s." "4 Like Socé, Senghor was also one of the first West African "boursiers" to receive a scholarship to study in France. He arrived in 1928 and began his studies at Lycée Louis-le-Grand in Paris. He continued his academic pursuits at La Sorbonne and by 1935 he had become the first African to earn the elusive "agrégation" for high school teachers. ${ }^{5}$ He was joined by several other young intellectuals hailing from Africa and the Caribbean: Socé, Birago Diop, Aimé Césaire, and Leon Gontran Damas, to name a few. Gary Wilder, in his book The French Imperial Nation State : Négritude and Colonial Humanism Between Two World Wars, explains that "a shared experience of racialization and access to a dynamic (French and colonial) cultural milieu contributed to the formation of Negritude." ${ }^{\prime 6}$ Far from their home, their darker skin no longer blended into the crowd and the racism they encountered in their daily lives served to further uncover the hypocrisy of the colonial system. To express their frustrations, these young intellectuals turned to writing. In doing so, however, they did not necessarily understand the significance their musings would soon represent. Several, albeit short-lived, journals published in these circles such as Légitime Défense (1932) and L'Étudiant noir (1935), exemplify the active intellectual climate of the time that resulted in the conception of Negritude. Wilder gives rare insight into this period citing Damas who explained, "we did not have the slightest idea that our student preoccupations would give birth to what we now call the Negritude movement [...] it was more of a spontaneous project [...] the reaction of a given category of individuals, in a

\footnotetext{
${ }^{4}$ Wendall A. Jean Pierre, “Léopold Sédar Senghor's Freedom I - Negritude and Humanism” The Harlem Renaissance: Revaluations, éd. Amritjit Singh (New York: Garland, 1989) 281.

${ }^{5}$ A competitive and higly-selective exam for high school teachers in France. Senghor taught Latin and classics in Tours.

${ }^{6}$ Gary Wilder, The French Imperial Nation State: Négritude and Colonial Humanism Between Two World Wars (Chicago : University of Chicago Press, 2005) 154.
} 
given milieu, at a given moment of history." ${ }^{7}$ Senghor captures the spirit of the decade well when in "Le message de Goethe aux nègre-nouveaux" (1964), he writes:

Ce furent, entre 1930 et 1939, les années d'ivresse du Nègre Nouveau en France. Munis des armes miraculeuses de l'écriture automatique, plus furieux que mitrailleuses, nous projetions sagaies empoissonnées et couteaux de jet à sept branches, nous faisions sauter tous les volcans de l'Éthiopie et ensevelissons, le jour de l'Ascension, tous les Saint-Pierre sous la pluie de feu de notre ressentiment. Nous le pensions du moins. ${ }^{8}$

Like so many of his contemporaries, Senghor's uniquely illustrious life in academics, literature, and politics can be traced to his first encounter with the French colonial education system at the age of seven. It was the 1930s, however, that marked his entry into activism. Recognizing the need to reclaim and revalorize the African cultural values that had been subjugated through colonialism, Senghor defined Negritude as "l'ensemble des valeurs culturelles du monde noir." Abiola Irele in his article "Négritude - Literature and Ideology" explains that, "Negritude can be seen as a counter-movement away from the [colonial states of subordination] that constitutes a symbolic progression from subordination to Independence, from alienation, through revolt, to selfaffirmation." Irele's definition suggests that there was a certain evolution inherent in Negritude and Senghor's own philosophical trajectory reflects this as well. To accomplish the mission of revalorizing African cultural authenticity and rejecting subjugating social and cultural hierarchies, there had to be a distinct turn inward characterized by racially focused introspection. Colonial subjects had to first define, promote, and praise that which made their culture unique and valuable and, likewise, early Negritude thought was at times criticized for being essentialist. In his famous

\footnotetext{
${ }^{7}$ Wilder 156.

${ }^{8}$ Léopold Sédar Senghor, Liberté I: Négritude et humanisme (Paris: Seuil, 1964) 84.

9 Abiola Irele "Negritude - Literature and Ideology," The Journal of Modern African Studies, 3.4 (1964) 499.
} 
preface to the 1949 collection of poetry L'Anthologie de la nouvelle poésie nègre et malgache de la langue française, "Orphée noire," Jean-Paul Sartre Sartre described Negritude's singular focus on race as a kind of "racisme antiraciste."

Often referred to as "enracinement" or the act reclaiming or reestablishing cultural roots, it is the term that best communicates the goal of Senghor's early works. ${ }^{11}$ For Senghor, this was manifested in writings dedicated to outlining Africans' strengths and aptitudes as well as poetry that sung the praises of his childhood, his homeland, and all that made his native Senegal beautiful and valuable on a global scale. Conceived from exile and the realization of the inaccuracies and false promises promulgated by the colonial education system and the continued biting reality of racial inequality, Senghor's early writing frequently juxtaposes political and social criticism with nostalgic imagery and cultural praise. This focus on racial legitimacy and the "return to the source" that defined "enracinement" was the natural first step in Negritude's larger project. Sartre also explained that "la poésie nègre" is first and foremost a "prise de conscience" and that "c'est d'abord de sa race qu'il faut prendre conscience." 12

The promotion of racial consciousness that defined early Negritude thought, however, created ideological distance between Socé and Senghor. The acceptance of selective assimilation, inherent in Socé's conception of cultural métissage, risked diluting the philosophy Senghor was seeking to define and was contrary to Negritude's early mission. Speaking with Nadine Dormoy Savage during the "Cinquième Biennale de la

\footnotetext{
${ }^{10}$ Jean-Paul Sartre, preface "Orphée noir," Anthologie de la nouvelle poésie nègre et malgache de langue française, ed. Léopold Sédar Senghor (Paris: PUF, 1948) xiv.

${ }^{11}$ Though "enracinement" can be translated as rooting or putting down roots, I will be using the French term in this project as it can communicate putting down or establishing cultural, racial, physical, spiritual, and linguistic roots - all of which are implied in Negritude's conception of "enracinement." The term is used repeatedly by the Negritude cohort when talking about the movement's early mission and Senghor's writings of the 1930s manifest the desire to ensure that this occurs in Africa.

${ }^{12}$ Sartre xiii - xiv.
} 
langue française" held in Dakar from December 1 - 8, 1973, Senghor describes

Negritude's evolution, referencing the singularity of the 1930s. To the question, "cette

notion de Négritude, qui vous est apparue si tôt, a-t-elle beaucoup évolué dans votre

esprit depuis ce moment-là?” he responded:

Non. Naturellement, parmi les jeunes artistes négro-africains qui sont venus après nous, certains ont dit que leur négritude n'était pas celle de Damas, Césaire et moi. Mais je dis que c'est idiot. Car qu'est-ce que la négritude? [...] La négritude, c'est l'ensemble des valeurs du monde noir. Cette définition restera valable tant qu'il y aura des Noirs et qu'ils n'auront pas changé. Ce qui peut être différent, c'est l'analyse qu'on en fait, car ce qui nous touchait surtout dans les années trente, ce que nous revendiquions, c'était ce qui était le plus opposé aux vertus de la langue française. Vous rappelez le vers de Césaire: "Et deux et deux font cinq!"13 C'est-à-dire que tout ce qui était rationalité, tout ce qui était clarté, tout ce qui était méthode, nous rejetions au nom de la négritude. Par ailleurs, comme l'a justement observé Jean-Paul Sartre, nous avions une attitude quelque peu raciste, nous vivions entre nous, dans la ferveur et dans l'autocontemplation. ${ }^{14}$ Maintenant, nous avons évolué. Notre attitude est en même temps une attitude d'enracinement dans la négritude, et une attitude d'ouverture aux vertus des autres civilisations, c'est-à-dire principalement de la civilisation européenne, ou plutôt, comme j'aime à l'appeler, de la civilisation euraméricaine. ${ }^{15}$

Senghor references the evolution in question, citing the 1930s as the most ideologically divergent period in his long career. Negritude's singular focus was on promoting the kind of racial valorization that fostered "une attitude d'enracinement dans la négritude." In its purest form, this priority did not allow for the openness the philosophy would later espouse and I would argue that this more radical period was a necessary and natural part of Negritude's larger project and philosophical trajectory.

\footnotetext{
${ }_{14}^{13}$ Aimé Césaire: Cahier d'un retours au pays natal (Paris: Présence Africaine, 1971).

14 "L'unité finale qui rapprochera tous les opprimés dans le même combat doit être précédé aux colonies par ce que je nommerai le moment de la séparation ou de la négativité : ce racisme antiraciste est le seul chemin qui puisse mener à l'abolition des différences de race." Sartre xiv.

${ }^{15}$ Léopold Sédar Senghor and Nadine Dormoy Savage, "Entretien avec Léopold Sédar Senghor" The French Review vol. 47, no. 6 (May 1974) 1066-1067.
} 
It is important to underline the role of reflection and self-awareness in the conception and manifestation of both Senghor's and Socé's philosophical projects. For Socé, the act of "autocritique" was necessary for Africa's evolution while Senghor cited "autocontemplation" in his 1973 interview. The differing choice of "critique" and “contemplation" provides telling insight into thinkers' contrasting views as "autocritique" suggests the need for collective criticism, while "autocontemplation" communicates meditation on oneself. To promote positive change and evolution in Africa, Socé adopted a philosophical approach that included criticizing aspects African culture that he felt hindered development. For Senghor, focusing too much on changing that which made his culture unique risked weakening Negritude's early mission. ${ }^{16}$ The 1930 s were integral years for rhetoric promoting "enracinement" and through self-reflection or "autocontemplation," cultural and racial qualities could be better defined and ultimately legitimized through writing and social action. In La poésie de l'action: Conversations avec Mohamed Aziza (1980), Senghor again reflects on his youth, acknowledging his wariness regarding both physical and

\footnotetext{
${ }^{16}$ Though overt criticism of African culture did not often enter into his rhetoric at this time, Senghor comes to the defense of Ousmane Socé in an entry he wrote for "L'Afrique Nouvelle: Bulletin Mensuel du Foyer France-Sénégal." Though only a few editions exist in the IFAN library in Dakar, Senghor contributed at least to the first and third issues. In an article from the third issue dated November / December 1936 and whose title was obscured, Senghor comments on partisanship and the intolerance of differing ideas among African intellectuals. He references violent criticism of Ousmane Socé that had recently appeared in ParisDakar. He writes "Enfin, lors que nous critiquons l'attitude de tel parti, que nous gourmandons notre peuple et le faisons honte de ses défauts, nous ne trahissons pas ce peuple. Car si nos paroles peuvent être exploitées contre lui, elles prouvent aussi que ce peuple est capable de se juger, surtout elles lui donnent l'occasion de rentrer en lui-même et de se reformer. Nous ne sommes jamais plus fidèles au peuple d'Afrique qu'en dénonçant les errements des partis et des clans, jamais plus fidèles qu'en lui présentant, à lui-même, le miroir de ses imperfections. Au surplus, nous comprenons que notre action puisse être impopulaire, pour le moment et très ingrate. Nous ne sommes qu'aux semailles. Puissent venir, un jour, les moissons." L'Afrique Nouvelle: Bulletin Mensuel du Foyer France-Sénégal no. 3 (Novembre et Décembre 1936) 4. Though it is unclear what exactly Senghor is referencing, Socé was condemned for the criticism of Senegalese culture that he included in his novel, Karim: Roman sénégalais. This was a manifestation of the notion of self-criticism (autocritique) that was as founding principle of his philosophy of cultural métissage.
} 
cultural métissage during Negritude's nascent decade, expressing ideas reminiscent of Socé's character Sidia in Mirages de Paris. He explained, “dans les années trente, tout ce qui était blanc - la raison discursive, la morale chrétienne, l'imitation de la nature, voire le socialisme scientifique et la femme blanche - tout était rejeté par nous au nom de la Négritude." ${ }^{17}$ Wilder further confirms these leanings, explaining that "a childhood friend of Damas' from Martinique who was métisse recalls that this trio of cultural missionaries [Senghor, Damas, Césaire] made weekly visits to her Paris apartment for palavers about Negritude. They criticized her for identifying with her white ancestors and for her willingness to marry a white man. ${ }^{18}$

As cultural métissage inherently required a certain acceptance of assimilation, Senghor could not fully embrace métissage à la Socé without undermining Negritude's mission of racial valorization. Since the term métissage was still used only selectively in the 1930s, these divergent views were often categorized as either assimilationist or antiassimilationist, even if these labels fail to communicate the nuance and full range of ideas expressed at the time. It does reflect, however, a certain split that had occurred among young African intellectuals that was clearly documented in reactions to Socé's and Senghor's speeches on the topic at the Dakar Chamber of Commerce in $1937 .{ }^{19}$ Senghor will eventually be known for championing cultural métissage and even criticized for his

\footnotetext{
${ }^{17}$ Léopold Sédar Senghor, La poésie de l'action (Paris: Stock, 1980) 184.

${ }^{18}$ Wilder 156.

19 The journalistic evidence of the opposing views regarding assimilation and métissage are discussed in the following chapter on Dakar-Jeunes, the nature of the discord was explicit and the main players clearly defined. Calling for continued discussion on the unresolved conflict, Socé in Dakar-Jeunes explains that “il n'est pas suffisant que la jeunesse, divisée en deux tendances, soit satisfaite, de part et d'autre, d'avoir bien défendu une position." He then attributes the opposing views to Senghor and Fily Dabo Sissako stating that "cette attitude est ce que nous appelions alors la tendance anti-assimilatrice." Ousmane Socé, "L’évolution culturelle de 1'A.O.F.," Dakar-Jeunes 29 Jan. 1942: 2
} 
own assimilationist tendencies, but his writings before the end of the Second World War reflect a reality that is often overlooked. ${ }^{20}$

\section{5: A Point of Departure}

The year 1935 saw not only the publication of Karim, but also the single-issue journal L'Étudiant noir, marking the logical point of departure for this study on cultural métissage. Ephemeral though groundbreaking in its execution, the journal included entries from Césaire, Senghor, and Paulette Nardal, an activist from Martinique. This was not, however, the first journalistic publication of this nature circulated in France, as for well over a decade, there were several important Pan-African journals dedicated to the unique interests and causes of colonial subjects. ${ }^{21-22}$ Philippe Dewitte in Les mouvements nègres en France: 1919-1939 explained that L'Étudiant noir, in contrast with its predecessors, was able to more effectively synthesize the ideas that had already been

\footnotetext{
${ }^{20}$ Philippe Dewitte provides the most complete portrait of Pan-African journals between the wars in his book Les mouvements nègres en France: 1919-1939. He categorizes Senghor as an "assimilationist" including him in a section dedicated to pro-assimilation writers and thinkers of the period and universally detects the promotion of cultural métissage in his writings, describing him as "L'Africain, amoureux de la culture européenne, l'humaniste socialiste [...]." Though overstated, these observations have been made when referencing Senghor's career as a whole. However in 1935, his stance was more nuanced, not fully embracing métissage or assimilation. Philippe Dewitte, Les mouvements nègres en France: 1919-1931 (Paris: L'Harmattan, 1985) 352.

${ }^{21}$ Pan-African journal that predated L'Étudiant noir:

\begin{tabular}{|l|l|}
\hline L'Action Coloniale & $1918-1928$ \\
\hline Le Paria & $1922-1925$ \\
\hline Le Libéré & $1923-1924$ \\
\hline Les Continents & $1924-1926$ \\
\hline La Voix des Nègres & $1926-1927$ \\
\hline La Race Nègre & $1927-1931$ \\
\hline La Dépêche Africaine & $1928-1932$ \\
\hline Le Cri des Nègres & $1931-1935$ \\
\hline La Revue du Monde Noir & $1931-1932$ \\
\hline Légitime Défense & 1932 \\
\hline L'Étudiant Noir & 1935 \\
\hline
\end{tabular}

${ }^{22}$ In addition to Philippe Dewitte, Christopher Miller provides useful insight into burgeoning pre-Negritude Pan-African movements in Nationalists and Nomads: Essays on Francophone African Literature and Culture (Chicago: University of Chicago Press, 1998).
} 
circulating about racial consciousness and valorization, giving a voice to the nascent Negritude movement. ${ }^{23}$

The question of assimilation was already of principal importance and Césaire's article "Jeunesse noire et assimilation," denounced the traditional colonial model. He explains, “L’assimilation, née de la peur et de la timidité, finit toujours dans le mépris et dans la haine, et porte en elle des germes de lutte, lutte du même contre le même, c'est à dire la pire des luttes. C'est pourqoui la Jeunesse noire tourne le dos à la tribu des Vieux. La tribu des Vieux dit: Assimilation. Nous répondons: Résurrection." ${ }^{24}$ This call to action and rejection of assimilation is characteristic of the period even if Senghor's writings generally took a less revolutionary tone than those of Césaire. ${ }^{25}$ Senghor was considered anti-assimilationist even if neither he nor Socé adhered perfectly to their designated camp. The middle ground, however, did not seem to be acknowledged at the time, though I would argue that both Socé and Senghor would fit somewhere in this dialectical space. Senghor always supported a cautious relationship between France and its colonies, especially in the domain of culture, even before fully championing cultural métissage. In his contribution to L'Étudiant noir, an article entitled 'L'Humanisme et

\footnotetext{
23 "En cette année 1935, les influences de La Revue du Monde Noir ou même de Légitime Défense, du Cri des Nègres et de La Race Nègre, se font sentir sur les écrits de L'Étudiant Noir qui cherchent à pousser plus avant, à théoriser, à synthétiser la pensée nègre des années précédentes. Les trois pôles, 'afro-latin,' révolutionnaire et nationaliste, du mouvement nègre, se retrouvent ainsi dans le petit journal des étudiants noir de Paris." Dewitte 353.

${ }^{24}$ Aimé Césaire, "Jeunesse noir et assimilation" L'Étudiant noir no. 1 (1935) 3.

25 "Aimé Césaire va beaucoup plus loin [que Senghor] dans la quête des racines nègres. La où Senghor voit le Nègre de l'avenir à mi-chemin entre deux cultures, le Martiniquais entend se débarrasser totalement des habits européens. Césaire est de toute évidence plus influencé par les nationalistes nègres, conscient des 'dégâts' occasionnés par l'assimilation il prend le contre-pied des thèses de Senghor. Pour lui, l'Antillais est Nègre avant tout, il n'a pas à copier les 'manières des Blancs."' Though his article in L'Étudiant noir is less militant than Césaire's there is little to suggest that the two disagreed philosophically at the time as Senghor often uses 'nous' (suggesting he, Césaire, and Damas) when referencing the racial focus of the 1930s. Though it would be false to attribute a full rejection of all things French to Senghor, there is considerable evidence suggesting that his more literal interpretation of Negritude did not translate to a full embrace of cultural métissage before the Second World War. Dewitte 357.
} 
nous: Réné Maran," Senghor pays tribute to the author of Batouala while hinting at Negritude's developing credo. Though the role of humanism is universal in Senghor's work, here he is calling specifically for "l'humanisme noir," again exemplifying Negritude’s influence, citing Réné Maran as embodying the racially specific interpretation of the term. He introduces the article explaining:

Il est vrai que nous devons dépouiller l'humanisme de tout ce qui n'est pas lui, non pour faire mourir "le vieil homme" en nous, mais pour le ressusciter. Il est donc vrai que l'humanisme doit aboutir à la découverte et à la connaissance de soi, à l'humanisme noir dans notre cas, que je définirais volontiers: un mouvement culturel qui a l'homme noir comme but, la raison occidentale et l'âme nègre comme instruments de recherches; car il y faut raison et intuition.

Not only does this passage contain the makings of the definition of Negritude, "les valeurs culturelles du monde noir," before the term is officially employed, but the Senghorian tropes of Black intuition and Western reason famously illustrated by the quote "l'émotion est nègre comme la raison hellène" from his 1939 essay "Ce que l'homme noir apporte." 26 Though often misinterpreted, this citation as well as its predecessor in L'Étudiant noir, announcing the inevitable marriage of "la raison occidentale et l'âme nègre comme instruments de recherche," suggest the inevitable role of European culture in the execution of his proposed project. Though Senghor did not yet officially embrace cultural métissage, he did not fully reject selective assimilation either. ${ }^{27}$ As early as January of 1937 , Senghor preached that “il s'agit d'assimiler, non

\footnotetext{
${ }^{26}$ Léopold Sédar Senghor, Liberté I (Paris: Éditions du Seuil, 1964) 24.

${ }^{27}$ In his article "The National Revolution in French West Africa: Dakar-Jeunes and the shaping of European civilizations," Harry Gamble explains that "although clear-cut, the differences between Socé's and Senghor's visions should not be exaggerated. Senghor admitted that new African elites needed to acquire some tools of modern European civilizations." Harry Gamble, "The National Revolution in French West Africa: Dakar-Jeunes and the Shaping of African Opinion," International Journal of Francophone Studies 10.1-2 (2007): 89.
} 
d'être assimilé," a phrase he will use in the title of his 1945 essay, "Vues sur l'Afrique noire ou assimiler, non être assimilés."28

\section{Assessing French West Africa's Cultural Problem: "Le problème culturel en A.O.F." and "Le congrès international de l'évolution culturelle des peuples coloniaux"}

Socé's and Senghor's twin speeches, "Impression d'Europe" et "Le problème culturel en A.O.F." were pronounced just over a month apart at the Dakar Chamber of Commerce in late summer of 1937. The controversy they inspired communicates a philosophical split that had developed between proponents and detractors of assimilation as well as cultural métissage at the time. Mirroring the dynamism of the African and Caribbean community in metropolitan France, French West Africa was also abuzz with change, as more liberal reforms such as the institution of l'École rurale populaire in 1934 sparked debates over the evolving relationship between France and its African subjects. ${ }^{29}$ With proposed education reforms that provided a more limited primary education tailored to the needs of rural populations, the question of assimilation became of particular interest to the community of évolués or the educated African elite who were divided on the issue. Socé and Senghor seemed to further catalyze already stirring passions with speeches proposing divergent programs for the role of assimilation in AOF. Senghor was clearly channeling early Negritude thought while Socé continued to promote his version of cultural métissage that included a form of self-criticism that displeased many of his contemporaries.

It is important to note that examples of journalistic writings from the Negritude cohort seem to diminish after 1935. L'Étudiant noir was limited to one edition and

\footnotetext{
${ }^{28}$ Léopold Sédar Senghor "Réflexions sur l'éducation africaine: De l'assimilation" Paris-Dakar 6 Jan. 1937: 1.

${ }^{29}$ See Chapter 3 for a more in-depth discussion on the Popular Front's influence in AOF at the time.
} 
forums for colonial self-expression were still scarce in France in years leading up to and during the war. ${ }^{30}$ Some publications in French West Africa, however, like Paris-Dakar, sponsored occasional writings from members of the African elite. Socé, Senghor, Sissoko and Abdoulaye Sadji were among those who contributed to Paris-Dakar in the mid to late 1930s while Dakar-Jeunes hosted not only Socé, but also Sadji, Mamadou Dia, Bernard Dadié, Amadou Hampâté Bâ, and several others in 1942. Only two of Senghor's essays from this period are still widely available and "Le problème culturel en A.O.F." as well as "Ce que l'homme noir apporte" (1939) can both be found in Liberté I: Négritude et Humanisme, the first of his five volumes of prose. As the remainder of this project is largely centered on dialogue occurring in French West Africa, it is important to recognize the integral role "L'évolution culturelle en A.O.F." had in bringing Senghor's Negritude-inspired message to the continent. In his article, "The National Revolution in French West Africa: Dakar-Jeunes and the Shaping of African Opinion," Harry Gamble explains that [Senghor] was taking the message of Negritude to a new African audience thus asserting the profound originality and hidden potential of Negro-African civilization and contending that the most important challenge of the day was to restore these values." 31

Both Socé's and Senghor's speeches were published in their entirety in ParisDakar and likewise their message was not limited to those who attended the conferences

\footnotetext{
${ }^{30}$ Failing to acknowledge several articles published in AOF in late 1936 and early 1937, Janet Vaillant suggests that Senghor's publishing was limited at this period to his contribution to L'Étudiant noir and "a few poems published in Cahiers $d u$ Sud, a literary magazine where he had a friend on the editorial board." She explains, "As for his impact on his own people in Africa, it was virtually nonexistent. Beyond the legend he had created at Lycée Van Vollenhoven as the boy from the bush who had won all the prizes, little was known about him. It had been almost ten years since he had left Dakar. In September 1937, this anonymity came to an abrupt end. That month Senghor made two public speeches, one in Dakar and one at an international congress in Paris." Janet Vaillant Black French and African: A Life of Léopold Sédar Senghor (Cambridge: Harvard University Press, 1990) 147.

${ }^{31}$ Gamble 88 .
} 
themselves. Distributed across AOF, their message reached a much larger audience and the public was quick to take sides in what would become an ongoing debate on assimilation. $^{32}$ Several articles appeared in the Paris-Dakar in the month following Senghor's speech, mostly speaking out in support of Socé, citing criticism he had received in the aftermath of the conferences. ${ }^{33}$ Still living in France at the time, Senghor did not contribute to the press in AOF as actively as Socé, however a series of articles on education published between January and April of 1937 entitled "Reflexions sur l'éducation africaine," as well as September's "Le problème culturel en A.O.F." and its build up, served to introduce his views to a broader African audience. ${ }^{34}$ He also contributed to L'Afrique Nouvelle: Le Bulletin Mensuel du Foyer France-Sénégal on at least two occasions in 1936, but Senghor's contributions to Paris-Dakar in 1937 undoubtedly had a more widespread influence. ${ }^{35}$

The organization that sponsored Socé's and Senghor's speeches, Le Foyer France-Sénégal, described itself as "la société mutuelle et de solidarité pour le développement de l'Enseignement." Professor Senghor was a natural fit for the organization's mission and his contributions communicate his burgeoning views on the desired nature of French-Senegalese relations. In an article from the bulletin's first edition entitled "Les conditions nécessaires d'action," Senghor criticizes the group's

\footnotetext{
${ }^{32}$ Gamble 89.

${ }^{33}$ The next chapter focuses directly on the reactions in the press. Limited to articles supporting Socé, it is clear that those who contributed, including Socé himself, were directly addressing criticism he received for "Impression d'Europe." In Le Danger, published in Paris-Dakar on September 29, 1937, Socé expresses his concern with Senghor's proposed reforms presented in "Le problème culturel en A.O.F."

${ }^{34}$ There were several articles published before Senghor's Chamber of Commerce speech dedicated to his biography and singing his praises. His speech was publicized more than Socé's suggesting the importance of Senghor's homecoming as he already had achieved a certain celebrity due to his successes in France.

${ }^{35}$ Published in three installments on January 6, 9, and April 30 1937, Senghor first addresses the question of assimilation, then "l'école rurale populaire" and lastly "l'école professionelle." Another article appearing on February 13, 1937 entitled "Fidelite des intellectuels" is a copy of the article he published in the third edition of L'Afrique Nouvelle: Bulletin Mensuel du Foyer France-Sénégal with only the last paragraph omitted.
} 
previous inaction, acknowledging that the establishment of a Foyer-sponsored publication communicates a real desire for reform. Though Senghor refused to fully espouse cultural métissage, he often communicated an acceptance of selective assimilation only when secondary to the mission of preserving and promoting African cultural and racial authenticity. In this article, he communicates ideas similar to those expressed in L'Étudiant noir as well as later in "Le problème culturel en A.O.F." He explains:

France-Sénégal Cap-Vert, cap avancé de l'A.O.F. vers la France, le Sénégal est le trait d'union historique, nécessaire, entre les deux pays; Il est le messager: mieux: l'ouvrier qui greffe le rameau français sur l'arbre africain. C'est ce qu'avaient compris les fondateurs et qu'il fallait fonder un foyer culturel. Garder les qualités africaines et les féconder et affiner au contact du génie français, c'était là le but. ${ }^{36}$

Failing to fully reject assimilation, Senghor's nuanced stance was again confirmed.

Though he was labeled as an anti-assimilationist, he condoned a form of carefully controlled assimilation that respected, first and foremost, African specificity. The tree analogy communicates his views well with the primacy of African culture and language symbolized by the image of a single French branch grafted onto an African tree. If Socé's views were similarly represented, the same tree would have several more French branches. It was thus the degrees of promoted assimilation and the rhetoric used that varied between the two intellectuals.

Like Senghor's earlier contributions in Paris-Dakar, the message of "Le problème culturel en A.O.F" focused primarily on education reforms that would promote his vision. If Socé's speech centered on comparing France and Africa, Senghor, clearly inspired by Negritude thought, sought to define the necessary role of race and culture in Africa's evolution. Though Socé indeed sang his continent's praises towards the end of

\footnotetext{
${ }^{36}$ Léopold Sédar Senghor, "Les conditions nécessaires de l'action." L'Afrique Nouvelle: Bulletin Mensuel du Foyer France-Sénégal no. 1 (Septembre 1936) 4.
} 
his talk, Senghor's homeland was his clear focus throughout. His primary message outlined a plan to promote African culture before opening the door for assimilation. The path he paved is not unlike his own philosophical evolution when considering his later work. The first stop in the journey must always be "enracinement" and here Senghor explains how this can be done and why it is essential for development. Though not his first published essay, it becomes clear why he chose to open Liberté $I$ with this particular text. Not only was "Le problème culturel en A.O.F." hugely influential due to the clear role it had in creating a dialogue about assimilation and cultural métissage in French West Africa, but the essay embodies the essential first step in Senghorian Negritude's foundation.

In his introduction, Senghor quickly informs the audience of the importance of race and culture in his proposed dialogue. His primary focus was outlining a new plan for growth that preserved and fostered the racial and cultural traits unique to Africa. It is in the essay, "Ce que l'homme noir apporte" that he outlines these distinctive characteristics, with the "âme nègre" or Black soul being the unifying source of African identity. As most of his writings at the time centered on education, this text was no exception as he argues that education and culture are inextricably linked. Senghor, who purposefully presents himself to his audience, not as an "agrégé de grammaire," but "en paysan de Sine," explains:

Si vous voulez bien nous tâcherons de définir le mot en fonction de l'Enseignement et de la Civilisation. Nous dirons que la Culture est à l'Enseignement ce que l'artiste est à l'ouvrier. Elle est imagination, esprit actif, car il y a, dans le mot, l'idée d'un dynamisme créateur. Je vous proposerai cette définition: une réaction raciale de l'Homme sur son milieu, tendant à un équilibre intellectuel et moral entre l'Homme et ce milieu. Comme le milieu n'est jamais immuable, non plus que la race, la culture devient un effort perpétuel vers un équilibre parfait, un équilibre 
divin. L'Enseignement est l'ouvrier et comme l'instrument de la Culture. Il consiste, pour l'enfant, dans l'acquisition de l'expérience accumulée des générations antérieures, sous forme de concepts, idées, de méthodes et de techniques. $^{37}$

Through education, African cultural heritage can be preserved thus fulfilling the task of “enracinement" that was so essential for early Negritude of the 1930s. Senghor communicates the risk of adopting a purely French model that is ill adapted to the targeted milieu. Expressing the threat the current system posed, Senghor explained that "le pôle Afrique perdra sa force d'attraction au profit du pôle France" if changes were not made. ${ }^{38}$ Wilder explains that Senghor "quickly acknowledged that through colonialism, Africans have been so fully incorporated into the Greater French nation, as well as the capitalist world order, that it is no longer possible to conceive of a distinct and authentic African culture."39 Though certainly oversimplified, since no one can argue that this had definitively occurred in AOF, a territory that was still almost entirely rural, this was the ultimate fear of those who argued against assimilation. ${ }^{40}$ As an alternative to assimilationist education policy, Senghor, therefore, presented a system of education that ensured African cultural fluency before introducing the French language and traditional Western disciplines to students. ${ }^{41}$ He sought to replace the immediate linguistic and cultural focus that defined French colonial education with a curriculum that would valorize African cultural identity through the incorporation of native languages in colonial classrooms, stating that "le temps de séduction est passé, il est temps de pendre

\footnotetext{
${ }^{37}$ Senghor Liberté I 11-12.

${ }^{38}$ Senghor Liberté I 14.

${ }^{39}$ Wilder 235.

${ }^{40}$ Tony Chafer, The End of Empire in French West Africa (Oxford: Berg, 2002) xv.

${ }^{41}$ Comparing his proposed system with the current one, Senghor explains: "On prendrait l'élève à cinq ans au lieu de huit et même dix. Pendant un, deux ou trois ans, on lui enseignerait, dans sa langue, des éléments de la géographie, d'histoire, de science, de morale indigène. À six ou huit ans, l'âme imprégnée de notre vieil idéal rénové, l'esprit exercé et déjà meublé, bien meublé, l'enfant aborderait, avec plus de fruit, ses études primaires." Senghor Liberté I 15.
} 
les séducteurs." education stating that "Il s'agit de partir du milieu des civilisations négro-africaines où baigne l'enfant. Celui-ci doit apprendre à en connaître et exprimer les éléments dans leur langue maternelle d'abord, puis en français [parce que] peu à peu, il élargira, autour de lui, le cercle d'univers où, homme, il sera engagé demain."43 He believed that the future was in the hands of the "nègre nouveau," a status that can only be attained by redirecting a focus onto African cultural values, with language being the first target. He explained that "le bilinguisme permettrait une expression intégrale du nègre nouveau." Understanding one's Negritude, or those cultural values that distinguished "les peuples noirs" from other civilizations, was the first step in Senghor's proposed program.

There is, however, a passage that Senghor chose to omit in the edition of Liberté I that appears in the Paris-Dakar transcript. ${ }^{44}$ Copying almost verbatim from the article, he published on the front page of the January 6, 1937 edition of Paris-Dakar "Réflexions sur l'éducation: De l'assimilation," Senghor addresses the question of assimilation directly, acknowledging its inevitable role in Africa's evolution as well as the subject's divisiveness in the African intellectual community. ${ }^{45}$ In the Liberté I version, Senghor does not avoid the question of assimilation all together. In the passage that precedes the five paragraphs of omitted text, he acknowledges the inevitability of assimilation in the current climate, explaining: “Que si nous voulons survivre, la nécessité d'une adaptation

\footnotetext{
${ }^{42}$ Léopold Sédar Senghor, Libérté I: Négritude et humanisme (Paris: Seuil, 1964) 11.

${ }^{43}$ Senghor, Liberté I 14.

${ }^{44}$ The only hint in the Liberté $I$ text is an extra space between paragraphs that is not included elsewhere in the essay. See Appendix.

${ }^{45}$ On editing the essays included in Liberté I, Senghor explains “ j'ai souvent, d'autre part, supprimé des citations faites déjà. Pas toujours, en particulier quand le contexte imposait la citation. Mais les thèmes demeurent; et aussi les idées, même quand les faits et l'expérience les ont révélées erronées. Ceci vaut surtout pour les idées politiques. En politique, on est rarement prophète. L'essentiel est d'être humble devant les faits: devant la vie." Senghor Liberté I 8.
} 
ne peut nous échapper: d'une assimilation. Notre milieu n'est plus ouest-africain, il est aussi français, il est international; pour tout dire, il est afro-français."46

Though always African first, the inevitable contact of cultures had resulted in a hybrid reality that could be rejected, promoted, or negotiated and Senghor referenced the relevance of the question in the first sentence he chose not to include Liberté I. Confirming the philosophical split and acknowledging the recycling of ideas, he writes "Vous voudrez me permettre de vous lire les lignes qu'au début de l'année j’écrivais sur l'assimilation: Assimilation ou non-assimlation, tel semble être le dilemme pour beaucoup." Senghor is quick, however, to underline the difficultly the question posed in a world where adaptation to a European model was already underway:

L'apport d'éléments étrangers n'est pas moins nécessaire. Les civilisations, comme les races, périssent de leur trop grande pureté. Très frappant est, à cet égard, l'exemple de la civilisation française. Le peu de matières dont elle est chargée lui fait un impérieux devoir de souvent se renouveler. Et toutes ses renaissances, si l'on y veut regarder de près, se sont faites sous des influences étrangères. Témoin aussi les civilisations africaines qui allaient croupissant, isolées des eaux vives du reste du monde par les solitudes du désert et de la forêt.

Mais ces éléments étrangers ne doivent être qu'aliments. Ils enrichissent une civilisation, ils lui donnent autre qualité, non autre direction. Il s'agit d'avancer dans sa ligne, de se développer en restant soi, d'évolution, non de révolution. ${ }^{47}$

Like Socé, Senghor references history, explaining that all civilizations are hybrid in some way, with purity being an impossible standard. Without using the term or explicitly promoting métissage, he is clearly acknowledging that eliminating all French influences in Africa was both impossible and undesirable. Therefore, the significant difference between Senghor's message and that of Socé's at the time was that Senghor was

\footnotetext{
${ }^{46}$ Senghor Liberté I 14.

${ }^{47}$ Léopold Sédar Senghor "Le problème culturel en A.O.F." Paris-Dakar 8 Sept. 1937: 2.
} 
accepting métissage's inevitability while Socé's was preaching the need for it. Métissage was much less an aspect of Senghor's philosophical program than an undeniable reality of the colonial situation. His primary message remained the promotion of racial and cultural authenticity (“se développer en restant soi”) while cultural métissage or assimilation was more of a side effect than an ultimate goal.

Likewise, it is important not to underscore the audacity of his overarching message. ${ }^{48}$ Janet Vaillant, in her biography on Senghor, cites the reaction of several young men who were present for the 1937 speech describing that "the lycée students and the intellectuals of the coming generation, recalled that they had been deeply impressed by his words, unable to believe a man of his experience and accomplishment would stand up for the study of African heritage." ${ }^{49}$ Senghor did not fully reject the possibility of selective assimilation in his speech, but this point was largely underscored by his Negritude-inspired message that preached the need for official policies that would ensure the preservation of African culture. One certainly cannot deny the power of his conclusion that borrowed words from Harlem Renaissance author Claude McKay to poetically communicate Negritude’s primary message:

Il est tard et vous allez partir. Laissez-moi vous reconduire loin sur le chemin. Prenez ce viatique, jeunes hommes et jeunes filles, mes camarades. Vous méditerez ces paroles de Claude McKay, le poète négroaméricain, natif de Jamaïque. Il nous dit, par la bouche de Ray, dans Banjo: "Plonger jusqu'aux racines de notre race et bâtir dur notre profond fond, ce n'est pas retourner à l'état sauvage: c'est la culture même."

\footnotetext{
${ }^{48}$ In later works, Senghor referenced the fallout and controversy his message inspired. In "Le problème des langues vernaculaires ou le bilinguisme comme solution" (1958), he wrote "lorsqu'en 1937, dans une conférence intitulée Le problème culturel en A.O.F.et donnée à la Chambre de Commerce de Dakar, je préconisais le retour aux sources, partant aux langues négro-africaines, ce fut un tollé général parmi l'élite négro-africaine (Senghor, Liberté I 228). Likewise, in Pierre Teilhard de Chardin et la politique africaine, he explained, 'Je provoquai un scandale, à Dakar, en préconisant, en 1937, le 'retour aux sources,' aux langues vernaculaires." Léopold Sédar Senghor, Pierre Teilhard de Chardin et la politique africaine (Paris: Seuil, 1962) 17.

${ }^{49}$ Vaillant 155.
} 
The words of McKay embody the heart of Senghor's argument promoting the reevaluation of assimilation policy that was contrary to Negritude's expressed purpose. His poignant words served to further ignite already stirring passions on the topic of assimilation in AOF. The reoccurring debates, controversy, and the resulting contributions to the press suggest that the terminology employed by Senghor to refer to the 1930s in France, "les années d'ivresse du Nègre Nouveau," could also be applied to the 1930s in AOF.

Senghor returned to France soon after his Chamber of Commerce speech, because he was slated to participate in the "Congrès international de l'évolution culturelle des peuples coloniaux," held in Paris. Commemorating the "mois colonial" of the 1937 International Exposition, the three-day event held on September 26, 27, and 28, hosted talks by colonial subjects including Senghor and Fily Dabo Sissoko as well as highranking members of the colonial administration. Back in the imperial capital, it seems Senghor capitalized on the momentum gained in Dakar to further propagate his message at the conference. The preface of the only vestiges of the event, the Rapports et compte rendu published in late 1938 suggests, however, that the assimilation debate was deemed unworthy of publication. On January 4, 1939, Socé published an article in Paris-Dakar entitled "Autour du Congrès de l'Evolution culturelle des peuples coloniaux" informing readers of the text's publication, writing that "le compte rendu des rapports qui ont été envoyés au Congrès de l'évolution culturelle des peuples coloniaux, vient d'être publié." Though Socé briefly mentions Senghor, whose only contribution was entitled, "La résistance de la bourgeoisie sénégalaise à l'école rurale populaire," the majority of his article is a biting criticism of Fily Dabo Sissoko's entry. Calling into question not only 
his fellow intellectual's arguments, but his education, Socé was rather unsparing in his critique of Sissoko's views. $^{50}$

It was in Sissoko's equally passionate rebuttal on January 27, 1939, where Senghor's full role in the conference became clear. Though Socé also acknowledged the fact in his Paris-Dakar critique, Sissoko was quick to inform readers that the Rapports et compte rendu was an edited selection. Many texts, Sissoko's included, were mere excerpts of the original communication, while some were not included at all. Incensed by Socé's attacks, Sissoko defended his views, providing what he felt was a more accurate summary of his report while voicing his anti-assimilationist leanings and resounding support for Senghor. He explained that the debate on assimilation was of great interest at the conference explaining that "la physionomie générale du congrès semble révéler un certain nombre de courants aux tendances diverses qui se ramènent toutefois à deux: tendances assimilatrices et les tendances adverses." Though this further proves the attention this topic received in both AOF and France at the time, there was little to no mention of the assimilation debate in the publication itself. Sissoko questioned this curious omission: "Mais la question qui semble avoir dominé les débats au point de n'avoir pu donner lieu à aucune communication écrite et dont tout le monde connaît l'ampleur et l'importance capitale, c'est la doctrine assimilatrice opposée à la doctrine adverse, anti-assimilatrice." He then cited Senghor as the leader of the antiassimilationist camp, suggesting that his talk on rural school reform was not his only contribution to the event, even if it was the only one selected for publication:

Les tendances anti-assimilatrices ont été défendues par le professeur Léopold Sédar Senghor. Mais, il ne paraît dans les Rapports et Compte-

\footnotetext{
${ }^{50}$ See Appendix for complete transcripts of the debate between Socé in Sissoko in Paris-Dakar in 1939.
} 
rendu, que par un article spécial : "La résistance de la bourgeoisie sénégalaise à l'École rurale populaire" (page 40). ${ }^{51}$

Though its seems that many of Senghor's words where never included in any official documentation, Sissoko's article confirms the future president's views and therefore his general resistance to assimilation policies and the notion of cultural métissage as it was conceived by Socé. In the publication's preface, Denis Blanche dismissively mentions the debate on assimilation, using Senghor's words to explain the anti-assimilationist argument for rejecting or, at the very least, re-thinking assimilation. ${ }^{52}$ This quote, that first appeared in the preface of the Rapports et compte rendu, before being cited in Sissoko's January 27 rebuttal, then in Socé's February 9 counter point article, and ultimately in Dakar-Jeunes, contains Senghor's strongest anti-assimilationist and thus anti-métissage rhetoric: “Appliquer le moule d'une civilisation qui n'est faite ni par eux ni pour eux, pour laquelle ils ne sont pas faits, ce serait commettre une erreur d'orientation, une véritable injustice pour aboutir finalement au métis culturel, revêtu d'un vernis, inassimilé par ce qu'inassimilable."53

The editors of the Rapports et compte rendu from the "Congrès international de l'évolution culturelle des peuples coloniaux" chose, however, not to include texts addressing the assimilation debate in the publication. Were the ideas too threatening to the colonial status quo or something more benign? Denis Blanche cites poor organization and a vague message when referencing the subject in the publication's preface while simultaneously acknowledging its huge influence on the conference. He writes that "une

\footnotetext{
${ }^{51}$ Fily Dabo Sissoko, "Réponse à Ousmane Socé: A propos du Congrès de l'Évolution Culturelle des peuples coloniaux," Paris-Dakar 27 Jan. 1939: 5.

${ }_{52}$ Denis Blanche, Préface, Le congrès international de l'évolution culurelle des peuples coloniaux: Rapports et compte rendu (Paris: Bibliothèque nationale imprimés, 1938) 18. See Appendix for Denis Blanche's full text.

${ }_{53}$ Blanche 19.
} 
question a été plus controversée que tout le reste, au point d'avoir dominé les travaux du Congrès: c'est celle des effets auxquels doit aboutir le contact des peuples aux colonies" and therefore the embrace or rejection of assimilation. His account diminishes the quality and content of the ideas expressed, and though he acknowledges the predominance of the question at the event, Blanche refuses to recognize its real value. He writes, "bien qu'elle ait donné lieu à des débats quelquefois pathétiques, la question était trop vaste pour faire l'objet d'une communication écrite, elle reste encore trop ouverte pour avoir fait l'objet d'un voeu." He does, however, try to shed some on the popularity of the antiassimilation stance, citing Senghor as the camp's leader. ${ }^{54}$ According to Blanche, the push for policies that respect indigenous African culture was "en vogue parmi les amateurs d'art nègre; elle sommeille au fond du coeur de certains amis des peuples coloniaux et de certains sociologues [...]. ${ }^{55}$ Yet regardless of the passionate discussion the question inspired and its admitted popularity, the editors chose only to mention it in the preface. Though Blanche admits that full assimilation is likely impossible, he is quick to discount the existence of "une civilisation nègre" or even "l'art nègre." The editors of the publication chose, rather, to mention the debate only to discount the legitimacy of the anti-assimilationist argument:

Nous n'avons pas cru devoir souscrire à cette théorie séduisante. Il n'est pas question, selon nous, de substituer, du jour au lendemain, une civilisation de type occidental à toutes les autres. Même là où cette substitution semble s'imposer, pour des raisons d'humanité, il faut beaucoup de science, de conscience et de patience. Mais la "civilisation nègre" est un mot vide de sens et il n'y a pas de référence aux métis des États-Unis qui tienne. La "race nègre," entendue comme une réalité anthropologique et comme l'auteur collectif d'une civilisation donnée, est

\footnotetext{
54 “Ces idées anti-assimilatrices furent reprises et rajeunies avec beaucoup d'autorité par un universitaire d'origine sénégalaise, M. Senghor. Il contestait aux nations civilisatrices le droit d'uniformiser le genre humain, sous prétexte de le civiliser." Blanche 18.

${ }^{55}$ Blanche 18.
} 
un mythe. "L'art nègre" en est un autre non moins sommaire, où l'on retrouve pêle-mêle une foule de productions plastiques, musicales ou chorégraphiques qui n'ont aucun rapport entre elles. Il est bon de respecter le Noir, meilleur de l'équiper, et de l'équiper largement, quelque dommage qu'en doive souffrir "l'originalité" chère aux amateurs de fétiches "nègres." Au reste, le problème n'est pas tellement un problème artistique. L'essentiel n'est pas d'obtenir le maximum de talent dans la production de poèmes ou de chansons. Il s'agit pour l'instant (et cela, le professeur Rivet l'a mis en lumière en des interventions décisives qui étaient de véritables leçons magistrales) de nourrir l'indigène, qui est sousalimenté, de le soigner, parce qu'il est souvent malade, de l'envoyer à l'école. La colonisation serait vaine, si elle avait pour but de faire l'Afrique un musée, un immense conservatoire de "civilisations" originales. ${ }^{56}$

Senghor's one text that was included in the Rapports et compte rendu, "La résistance de la bourgeoisie sénégalaise à l'École rurale populaire" does, however, shed light on the assimilation debate even if only in terms of the paper's expressed theme: the new rural school policies in AOF. ${ }^{57}$ The Popular Front and Governor General Marcel de Coppet's more liberal association policies were generally popular among the educated African elite, many of whom lived in urban centers where a job in the colonial administration equaled social and economic success. The only way to achieve this goal, however, was to have the necessary French diploma and therefore an assimilation-style education. Launched in 1934, l'École rurale populaire instituted a new reformed curriculum that targeted the specific, and more limited, academic needs of rural communities and was a departure from the assimilation model. The urban intellectual community was, therefore, almost unanimously opposed to the new measures. Senghor explains the fear motivating the reforms' detractors:

L'enseignement est un instrument de culture; c'est aussi une sorte de gagne-pain: il prépare à la profession. Notre bourgeoisie ne l'ignore pas.

\footnotetext{
56 "Blanche 19.

${ }^{57}$ See Appendix for the full text.
} 
Elle sait que pour remplir certaines fonctions - dans l'administration, en particulier - il faut posséder un diplôme identique à celui que délivre la Métropole; que d'autres fois, il faut subir un concours qui exige des connaissances identiques à celles des candidats métropolitains, d'où, poursuit-elle, la nécessité d'une assimilation qui permettra d'obtenir diplômes et connaissances identiques. L'assimilation doit être à la base, à l'École primaire: elle proscrit l'École rurale populaire et l'africanisation de l'enseignement en général. ${ }^{58}$

Senghor writes, “On n’a pas assez dit la résistance que lui oppose et lui oppose encore la bourgeoisie des 'evolués,' la bourgeoisie sénégalaise plus que les autres, qui donne le ton aux autres. Elle est frappante pourtant la quasi-unanimité du mouvement."59 Those against the policy saw the reforms as a sign that the colonial government was trying to place a cap on the advancement of indigenous populations by limiting education to more manual and artisanal trades. They feared that a trickle-down effect could eventually restrict the urban population's access to the kind of education necessary for more advanced, modern careers, that city life necessitated. ${ }^{60}$

Though the majority of the African elite was against the new education policies, Senghor was not: much of the philosophy he outlined in "Le problème culturel en A.O.F." defended the need for a culturally specific model. In this speech, Senghor called for the Africanization of primary schools, a message not unlike the measures being instituted in the West African countryside. An education adapted to rural needs ensured the ability to promote and preserve traditional lifestyles as well as artisanal and agricultural trades while giving Africans the means to succeed in a world where basic literacy was increasingly necessary. Likewise, by tailoring the rural schools to the

\footnotetext{
${ }^{58}$ Léopold Sédar Senghor, "La résistance de la bourgeoisie sénégalaise à l'école rurale populaire" $L e$ congrès international de l'évolution culurelle des peuples coloniaux: Rapports et compte rendu (Paris: Bibliothèque nationale imprimés, 1938) 42-43.

${ }^{59}$ Senghor, "Résistance" 40.

${ }^{60}$ Senghor cites a number of articles in the press namely from Le Périscope Africain, Le Jeune Sénégal, L'A.O.F, and Le Progrès between 1934 and 1937.
} 
specific needs of the village life, African culture was being respected and fostered.

Senghor and other policy supporters viewed the reforms as a welcome manifestation of their desired focus on African culture:

Rien d'étonnant, dès lors, que notre bourgeoisie ne comprenne pas le mouvement culturel franco-africain, dont l'école rurale est une des expressions. Le mouvement est né d'une conception toute moderne de la culture. Celle-ci consisterait à "cultiver sa différence" comme le veut André Gide; elle consisterait dans une réaction raciale de l'homme sur son milieu pour s'en servir comme instrument de perfection morale et intellectuelle. ${ }^{61}$

The ubiquitous emphasis on culture in all of Senghor's writing from this period communicates the role of "enracinement" in his early philosophical evolution while exposing the complexity of the assimilation question. The colonial administration under De Coppet and the Popular Front already favored an association-style colonial policy over assimilation and institution of l'École rurale populaire was a product of this more liberal approach. While the colonial administration was reexamining its own policies, increased traction on the topic of assimilation in the press opened the debate to a larger population. How going forward, given the more liberal policies instituted in AOF, would colonial subjects ideally reconcile the opposing cultural forces acting on their lives? The question was complex since professional obligations and cultural allegiances were not always perfectly compatible. Likewise, Senghor's writings paint the nuanced picture of a man who struggled to negotiate the linguistic, cultural, and political duality of the colonial system.

Scholarly portraits of Senghor's life and literary activity in the 1930s as well the poet-president's own autobiographical reflections, communicate strong antiassimilationist views. His writings however convey an early, albeit hesitant, acceptance

${ }^{61}$ Senghor "Résistance" 42. 
of the kind of selective assimilation that Socé encouraged at the time. Though the 1930s were undoubtedly Senghor's most radical decade, his ideas already suggest that he had taken the first steps in his eventual evolution towards the explicit acceptance of cultural métissage. That said, his culturally focused, Negritude-inspired rhetoric largely overshadowed any early "assimilationist" leanings. Cultural métissage was not yet his chosen program for African development but an undeniable reality of a bipolar society that had to be acknowledged, even if only cautiously. The two camp system that had been established between the assimilationists and anti-assimilationists failed to communicate the debate's inherent nuance, as I have found no evidence of African intellectuals promoting pure assimilation at the time.

\section{Universal Civilization}

Senghor's writings in the 1930s portray a thinker torn between a rejection of assimilation in accordance with his faith in Negritude's transformative value and the realism that it cannot be fully avoided. Though it can be difficult to reconcile Senghor's anti-assimilationist reputation in the 1930s with some of the more moderate views he concurrently expressed, it seems Senghor resolved this conflict by placing the control of assimilation in the hands of the colonized, not the colonizer. He first used the credo “assimiler, non être assimilé" in 1937, proposing a new interpretation of colonial assimilation that placed the onus on Africans to choose what elements of Western culture would benefit society. This reversal of the colonial assimilation construct eventually evolved into a more utopian philosophy that saw cultural métissage as the great equalizer: an inevitable cultural force that would lead to the mutual betterment of all who participated as equals. Though Pascal Brousseau in his dissertation on Socé's life and 
works attributes Senghor's embrace of cultural métissage to his 1945 essay "Vue sur l'Afrique noire ou assimiler, non être assimilé," it his clear he was expressing like ideas even earlier. ${ }^{62}$ The Senghor of the 1930 s remains somewhat enigmatic as manifested through his clear reputation as an anti-assimilationist who expresses a hesitant acceptance of selective assimilation. Likewise, it is futile to attribute a date or a specific publication to his official adoption of cultural métissage, though in Poésie de l'action he does cite the war years as integral in his evolution. After being released by the Germans from a camp for prisoners of war, Senghor began rereading the Greek classics and was reminded of the formative role that both physical and cultural métissage played in Greek civilization. He explains that, “cette découverte, refaite en face du nazisme, m’a aidé à changer ma vie, à m'orienter peu à peu, vers la théorie du métissage culturel comme idéal de civilisation." Senghor's views on métissage evolved gradually, from the moment he began writing. There was no single philosophical watershed, but rather a steady increase in an acceptance of métissage that ultimately resulted in his conception of "la Civilisation de l'Universel" in the late 1950s.

He references "la Civilisation de l'Universel" as early as 1958 in the preface of L'Anthologie de la vie africaine, a text he also included in Liberté I, writing that "dans l'élaboration de la Civilisation de l'Universel qui s'ébauche maintenant, sous nos yeux,

\footnotetext{
62 "L'idée du métissage culturel commence clairement à apparaître dans les textes de Senghor à partir de 1945, avec le publication de "Vues sur l'Afrique noire ou assimiler, non être assimilé." Cet essai, qui n'est dédié à nul autre que Robert Delavignette, représente l'un des points tournants dans l'évolution de la pensée de son auteur. Dans ce texte, Senghor s'oppose résolument à l'assimilation passive de l'Afrique par l'Europe. En fait, c'est tout le processus qu'il souhaite renverser: il veut, d'une part, qu'elle assimile seulement certains éléments européens spécifiques qui pourront jouer un rôle dans le progrès et l'épanouissement de l'Afrique. [...] L'idée du métissage sera à son apogée en 1950, dans un texte intitulé "Afrique s'interroge: subir or choisir" [...]. Pascal Brousseau, Vie et cuvre de l'écrivain sénégalais Ousmane Socé Diop: Démonstration d'une injustice littéraire et intellectuelle, et révélation d'un moment caché de la littérature africaine diss., University of Virginia, 2005, 142-143.
} 
1'Afrique noire ne sera pas absente." ${ }^{33}$ It was the work of Jesuit priest and philosopher Pierre Teilhard de Chardin that ultimately provided Senghor with the philosophical foundation that allowed him to reconcile Negritude with selective assimilation and fully embrace cultural métissage. In Pierre Teilhard de Chardin et la politique africaine, Senghor writes "et bien, ces impasses où nous étions acculés, Teilhard de Chardin allait nous aider à en sortir." [...] Il allait nous permettre [...] d'apporter notre contribution à la Civilisation de l'Universel: de nous 'socialiser' sans nous 'dépersonnaliser,' sans renier les valeurs de la Négritude." ${ }^{44}$ Writing after WWII, Teilhard de Chardin wrote of the inevitable creation of a universal civilization based, in part, on the complementary character of races and the necessary synthesis that must occur for civilizations to thrive: "les collectivités humaines les plus humanisées nous apparaissent toujours finalement, comme le produit non d'une ségrégation mais d'une synthèse." Senghor's seemingly contradictory messages of the 1930s were therefore replaced by a theory that embodied his own philosophical evolution of the past two decades, requiring the equal embrace of both Negritude and cultural métissage for its execution. ${ }^{65}$ Teilhard de Chardin claimed that "il faut des nations pleinement conscientes pour une terre-totale" and the promotion of the values of Negritude ultimately complimented this expressed goal. The period of “enracinement” that characterizes Senghor's early work was necessary if Africa wanted to meaningfully contribute to "le rendez-vous du donner et du recevoir," the symbolic

\footnotetext{
${ }^{63}$ Senghor, Liberté I 240.

${ }^{64}$ Senghor, Pierre Teilhard de Chardin 33.

65 "These superficially contradictory ideas, that Negritude must be preserved and developed, and that the only way for a civilization to grow and develop is by taking nourishment from other peoples and cultures, found their reconciliation in an all-encompassing theory that Senghor began to articulate in the late 1950s." Vaillant 265.
} 
place of exchange that would come to define "la Civilisation de l'Universel." $"$ First used by Césaire, but frequently repeated by Senghor, Vaillant explains this now well-known expression as "the grand moment of give-and-take in which each culture selects what it most needs from others, and in which each is thereby enriched." ${ }^{, 67}$ Therefore, by continuing to promote Negritude's philosophical program, Africa would not only be able to better articulate its own strengths, but recognize that which could benefit from outside influence. In 1961, Senghor explains this process in a talk at the Sorbonne:

Ne croyez surtout pas que les militants de la Négritude manquent de modestie. Aujourd'hui plus que jamais, nous sommes conscients de nos défauts: des lacunes de la Civilisation négro-africaine. C'est pourquoi nous avons toujours refusé de refuser les apports européens, singulièrement les valeurs françaises. Celles-ci sont complémentaires des nôtres. Comme le disait Pierre de Teilhard de Chardin, les races ne sont pas d'une égalité mathématique, elles sont d'une égalité complémentaire. Et la Civilisation de l'Universel se situe exactement au Carrefour des valeurs complémentaires de toutes les civilisations particulières.

Pour cette raison, mon pays, le Sénégal, tente, en Afrique noire, un effort culturel original et, peut-être, sans précédent. Nous voulons nous enraciner au plus profond de l'Africanité, dont la Négritude n'est qu'un aspect, et, en même temps, demeurer ouverts aux quatre vents du monde $[\ldots]{ }^{68}$

These ideas call for the same kind of cultural métissage Socé was preaching in the 1930s that required active self-criticism or "autocritique." Socé's speech "Impressions d'Europe" was dedicated largely to comparing the two poles of influence, Africa and Europe, enumerating their respective strengths and weaknesses. Though Socé presented Africa largely in terms of its developmental delay, he spoke of Africa's moral superiority. He explained that "il nous faut donc, en imitant l'Europe, profiter de la leçon de son

\footnotetext{
${ }^{66}$ First used by Aimé Césaire, Senghor frequently uses this quote when referencing la Civilisation de l'Universel.

${ }^{67}$ Vaillant 265-66.

${ }^{68}$ Senghor Liberté I 318.
} 
expérience, ne commettons pas à notre tour la maladresse de négliger ces grandes forces humaines qui sont les valeurs morales. Il nous faut nous discerner. Il nous faut nous connaître d'abord avant de construire et ne jamais nous oublier en construisant." ${ }^{69}$ Socé, like Senghor, only prescribed change when coupled with a respect for the past. Though his message of "enracinement" was never as systematic or strong as Senghor's, its undeniable presence suggests that the philosophical rift between the two thinkers many never have been as great as it was portrayed in the West African press.

Senghor's philosophy of cultural métissage, manifested by the conception of "la Civilisation de l'Universel" combines the values of Negritude, Teilhardian metaphysical thought, and selective assimilation. The result is an eloquently articulated, utopian model for African (and global) cultural evolution. As this theory dominates the majority of his career, Senghor will be forever associated with cultural métissage. His early writings, however, portray a thinker who struggled to come to terms with the kind of cultural compromise inherent in the philosophy that Ousmane Socé always endorsed. As this study continues to trace the evolution of cultural métissage into the 1940s and 1950s, the contributions of Socé, Senghor, and even Fily Dabo Sissoko shed light onto the controversial questions and debates that impassioned a generation. From Karim, to L'Étudiant noir, to the Dakar Chamber of Commerce speeches, and eventually DakarJeunes, the question of cultural métissage was omnipresent in AOF, with Socé and Senghor's names being associated with opposing camps. Even if manifested more frequently in the 1930s in terms of assimilation, the question remained the same. How can colonial subjects reconcile the opposing cultural forces acting on their lives? The following chapter builds on the foundations established in the 1930s as Socé again

\footnotetext{
${ }^{69}$ Ousmane Socé “Impressions d’Europe” Paris-Dakar no. 462 August 6, 1937.
} 
tackles the question of assimilation in AOF, this time in the unlikely context of Vichy rule. 


\section{Chapter 3}

\section{An Unlikely Host: Dakar-Jeunes, Cultural Métissage, and Vichy's National Revolution}

By the onset of the Second World War, Ousmane Socé had articulated his argument supporting cultural métissage repeatedly in this novels, public appearances, and frequent contributions to the press. The debates between him, Senghor, and Fily Dabo Sissoko were widely disseminated, as Paris-Dakar was open to publishing select contributions from colonial subjects. It was Socé's openness to selective assimilation that likely helped earn him a certain privilege with editors making him one of the most prolific African contributors to the local press at the time. Focusing most frequently on culture, his articles communicate one side of a lingering debate on assimilation that impassioned many of his compatriots. By 1939, however, content in the press turned its attention to the build up to the war, and the heated debate between Socé and Sissoko that Paris-Dakar published in January of that year remained unresolved. Times had changed, and the colonial administration was not immune to the turmoil in Europe. The political climate during the war presented unique challenges for African journalistic production. The now Vichy-controlled government instituted more conservative policies in AOF and colonial subjects did not enjoy the same freedoms of the previous decade. However, in hopes to bolster more support from the educated African elite for the changes in AOF, the editors of Paris-Dakar created Dakar-Jeunes. ${ }^{1}$ This new weekly newspaper became the unlikely host of a uniquely candid debate on cultural métissage.

\footnotetext{
${ }^{1}$ Dakar-Jeunes ran from January 8, 1942 to February 25,1943 and the only known complete collection exists in the shared Bibliothèque Nationale du Sénegal (BNS) and Archives Nationale du Sénégal (ANS), both located in the Building Administratif on the Avenue Léopold Sédar Senghor in Dakar, Sénégal. I was able to digitize the full collection on a trip there in January of 2011.
} 
This chapter will trace this next step in the evolution of cultural métissage in AOF in order to better understand not only the influence of Socé, Senghor, and Fily Dabo Sissoko on the discourse, but the integral role this little-known publication had in the philosophy's historical trajectory. To grasp the importance and singularity of the debate published in Dakar-Jeunes, it is important to understand the nature of the Vichy regime in $\mathrm{AOF}$, its propaganda, general ideologies, and the contradictory rhetoric that allowed for this short-lived newspaper to exist and publish such culturally sensitive articles. Though I will provide further insight into the debate's 1937 origins at the Dakar Chamber of Commerce and trace its evolution during the Vichy years in AOF, I seek to show how the landmark discussion on cultural métissage that occurred in Dakar-Jeunes in 1942 was able to take place in a period that would seem otherwise hostile to such musings. The general context and deliberate purpose of Dakar-Jeunes was not to create an open forum for discussion for African youth and intellectuals, but to promote Vichy's National Revolution ideology among the educated African elite. To comprehend the political motivation behind Dakar-Jeunes, it is important not only to contextualize the events that ensured Vichy control in AOF in the early days after the Armistice and the policy changes that immediately ensued, but the propaganda that the colonial administration used to promote and ensure the loyalty of its subjects to the cause. Dakar-Jeunes is, at the core, one of these vehicles of propaganda. It was a very different kind of publication than Paris-Dakar.

A weekly paper, appearing every Thursday, Dakar-Jeunes explicitly targeted the young educated elite, a population that the Vichy authorities wanted to closely monitor and whose support was vital to a collaborative government on a continent where Gaullist 
support was swiftly gaining ground. In what seems to be a gesture to ingratiate a population with a tailor-made publication, the editors of Dakar-Jeunes treated topics deemed more relevant for the target demographic such as French and African culture, scouting, and sports instead of focusing on political, economic, or wartime news. This extraordinary publication exemplifies, however, a primary weakness of Vichy's National Revolution ideology of "Work, Family, and Fatherland," especially as it was manifested in the colonial context. By promoting traditional African values in the name of ideological reform, the colonial administration sought to ensure Africans' loyalty, snuffing out the desire for social and economic advancement by promoting a traditional lifestyle.

\section{Sociopolitical Introduction}

If the Popular Front's policy reforms suggested a shift towards a more open and altruistic form of colonialism in AOF, Africans' hope for fair treatment and political autonomy was once again thwarted with the onset of the Second World War. After France's devastating defeat to the Germans, and the signing of the Armistice with their vanquishers on June 22, 1940 that would place Marshal Henri-Philippe Pétain in power of the new collaborative Vichy-based government, French West Africa and the whole of the Empire was to undergo an administrative and ideological overhaul that scholars consider a watershed moment for the future of French colonialism. AOF was not immediate in its support for Pétain's Vichy government, first considering Charles de Gaulle's call from London on June 18, 1940, which implored the Empire to continue the fight against Germany rather than rally around the Marshal. ${ }^{2}$ However, after some

\footnotetext{
${ }^{2}$ Ruth Ginio, French Colonialism Unmasked: The Vichy Years in French West Africa (Lincoln: University of Nebraska Press, 2006) 6.
} 
jockeying with leaders in North Africa and French East Africa (AEF), AOF quickly and enthusiastically rallied around Pétain, largely due to the newly appointed High Commissioner of French Africa, Pierre Boisson's passionate appropriation and promotion of Vichy's National Revolution ideology. In stark opposition with reforms put forth by the Popular Front in the years leading up to the war, the Vichy regime installed a more severe form of colonialism that sought to promote tradition over modernization and embraced more overtly racist policies. By promoting a more traditional existence for its subjects, France could better ensure African subjugation. In her article, "Les enfants africains de la Révolution Nationale: la politique vichyssoise de l'enfance et de la jeunesse dans les colonies de l'AOF (1940 - 1943)," Ruth Ginio shows how education policies reflected a fear of over-education. ${ }^{3}$ Wary that a highly educated African population would be more likely to revolt against the government and undermine the glass ceiling inherent in colonial policy, the Vichy administration took steps to dissuade primary school students from seeking higher education, hoping to ensure that the vast majority of colonial subjects were farmers and laborers and that the class of "évolués," the educated African elite, would cease to grow. ${ }^{4}$ Though l'École rurale populaire had been established before the war, the motivation for education reform during Vichy rule was not another manifestation of more liberal colonial association policies. The new motivation reflected, rather, the fears expressed by opponents of rural school reform before the war who felt the administration was trying to limit Africans' access to higher

\footnotetext{
${ }^{3}$ Ruth Ginio, "Les enfants africains de la Révolution nationale: la politique vichyssoise de l'enfance et de la jeunnesse dans les colonies de l'AOF (1940 - 1943)," Revue d'histoire moderne et contemporaine, 49.4 (Oct. - Déc. 2002).

${ }^{4}$ Ginio, one the foremost scholars on the Vichy years in French West Africa, cites a 1942 decree that replaces the previous one from 1924. This new order rescinds old verbiage, stating that village primary schools will no longer be seen as the first step of instruction leading to the possibility of more advanced schooling. Students in village schools will now receive basic elementary education with a fixed term of four years, after which students will return to their families. Ginio, "Les enfants africains" 139.
} 
education and lucrative careers. ${ }^{5}$ In addition to education reform, the government in AOF increased censorship and covert intelligence operations, and revoked previous longstanding freedoms such as the right of the "originaires," or the residents of the Senegal's Four Communes (Dakar, Rufisque, Saint Louis, and Gorée) to send a deputy to the National Assembly in Paris. ${ }^{6}$

These new policies and ideologies that were designed to ensure and tighten the oppressive colonial hierarchy, may have instead promoted nationalist rhetoric that had been circulating, for at least a decade prior, in France as well as in AOF. By 1940, Senghor, Césaire, and Damas had already begun propagating the tenets of Negritude, even if publications from the cohort were still limited. The activist pioneers of Negritude had to first turn inward for an introspective evaluation of their unique traditions, languages, and art before they could call for the equality that the Western world had so long denied. Vichy's emphasis on the promotion of a more traditionalist African society inadvertently reflected many of the same themes as Senghorian "enracinement." This unlikely connection played into the hands of many educated Africans, who saw embracing tradition as the first step towards gaining cultural and political legitimacy, and eventually, putting an end to colonial subjugation. ${ }^{7}$

\footnotetext{
${ }^{5}$ See Chapter 2 for more information on the opponents and supports of the rural school reforms in AOF.

${ }^{6}$ Ruth Ginio, "Marshal Pétain Spoke to School Children: Vichy Propaganda in French West Africa, 1940 1943," The International Journal of African Historical Studies, 33.2 (2000): 297.

${ }^{7}$ In his book Vichy in the Tropics, Eric T. Jennings makes a similar observation. Though his work focuses on French Indochina and Guadeloupe, his conclusions can apply to the Empire as a whole. Jennings suggests the ways in which Vichy's policies and ideologies may have backfired, garnering support for nationalist and anti-colonial causes rather than winning the hearts and minds of France's subjects. He explains, "the Vichy regime quite unwittingly set in motion several forms of opposition in its 'loyal colonies.' It did so on two levels; first by hardening an already ruthless colonialism; second, and more ironically, by introducing to the Empire, Pétain's cherished themes of authenticity, tradition, and folklore. In this way Pétainist ideology interacted with a nexus of indigenous nationalist themes. [...] It would appear that Vichy officials inadvertently created a setting in which their own reductionist ideologies, folkloric nostalgia, and language of particularism were actually turned against them." Eric T. Jennings, Vichy in the Tropics (Stanford: Stanford University Press, 2001) 3.
} 
The core of the Vichy ideology centered around a rewriting of the ubiquitous French revolutionary philosophy, "Liberté, Egalité, Fraternité" in favor of a new credo, "Travail, Famille, Patrie" or "Work, Family, Fatherland." This more radical triptych, that paralleled many concurrent fascist ideologies taking hold in Europe at the time, was promoted widely both in France and in AOF through extensive propaganda campaigns and networks. Ruth Ginio explains that Pétain blamed the Third Republic's focus on core republican ideals for the country's current failings and believed that only a renewed focus on tradition, morality, and agriculture could one day restore the country to its former glory. By returning to the earth and traditional Catholic values, Pétain was calling for a return to the "True France." This purist philosophy was also a xenophobic one, whose quest for authenticity also warranted actions against Jews, Free Masons, and Communists in metropolitan France and more overt racism in the colonies. ${ }^{8}$ However, when considering the two opposing philosophies together, one can see how Pétain's National Revolution ideology was not rebuked, but rather adopted, in AOF. The motto "Work, Family, Fatherland" was much more harmonious with Africans' traditional existence than "Liberty, Equality, and Fraternity," which had repeatedly proved itself to be a hollow and misleading promise in the colonial context.

\section{The Origins of the Debate}

Vichy's promotion of traditional African values was immediately exemplified in Dakar-Jeunes. Ousmane Socé took advantage of the unique forum Dakar-Jeunes afforded, to revisit a debate that first occurred in Dakar in 1937 as a result of he and Senghor's twin speeches at the Dakar Chamber of Commerce and again in 1939, in a heated exchange he had with Fily Dabo Sissoko in Paris-Dakar. Though the content of

\footnotetext{
${ }^{8}$ Ginio, "Les enfants africains" 136.
} 
the speeches themselves is discussed in depth in the previous chapters, published responses and reactions provide important insight into the questions and concerns that would be addressed in Dakar-Jeunes in 1942. Since the local press covered the events extensively, several articles published in the weeks after Senghor's speech reference their critical reception. Though both were initially well received, activity in Paris-Dakar beginning in late September 1937 suggests that Socé came under attack by some of his compatriots who were more swayed by Senghor's anti-assimilationist message, even if the French mouthpieces effusively sang the novelist's praises. It is in these articles that the schism between the assimilationists and the anti-assimilationists, Socé's stated motivation for the Dakar-Jeunes debate, first becomes apparent.

Socé's speech “Impressions d'Europe," and Senghor's "Le problème culturel en A.O.F.," both addressed the importance of African culture in the continent's current and future development. I have shown, however, that Socé focused specifically on the importance of cultural métissage, while Senghor took a more hard-lined, Negritudeinspired approach to his proposed path for the future of AOF, exemplified by his support for the Africanization of primary school education. Reaction in the press shows that a rather over-simplified line was drawn, with Socé being associated with assimilation and Senghor with the rejection of the assimilationist model. The reality of each man's stance was more nuanced, as Socé's interpretation of métissage did not call for the full appropriation of French culture and was much more compatible to Senghor's future philosophy, "la Civilisation de l'Universel," than reactions in the press suggest.

The first response appeared just three days after Socé's July 31, 1937 talk, on the front page Paris-Dakar in a brief article entitled, "La conférence de M. Socé a remporté 
un succès triomphal à la Chambre de Commerce." Only containing high praise for his message, the article portrayed Socé as an exemplary product of the colonial education system:

M. Diop Ousmane Socé nous avait déjà bien démontré que l'on peut fort bien, après avoir passé une partie de sa vie dans la brousse africaine, devenir un brillant élève, passer avec succès ses examens à Paris et profiter des loisirs que laisse l'étude de l'art vétérinaire pour tenter sa chance dans les lettres.

Senghor himself served as the President of the conference, as he was an active member of Le Foyer France-Sénégal and a contributor to the organization's monthly publication. The article describes that Senghor introduced Socé to the sold out crowd where "plus de quinze cent personnes pendant plus d'heure [l'écoutaient] dans un silence religieux." ${ }^{\prime 9}$ It is important to note that there is little to suggest that Senghor himself had a role in the post-conference debate that the twin speeches inspired. He was only in Dakar temporarily at the time, as he had to quickly return to Paris to participate in the "Congrès international de l'évolution culturelle des peuples coloniaux," an event that further solidified his role as the symbolic leader of the anti-assimilationist camp in AOF.

Senghor's speech was even more highly publicized, and in the build-up to the September $4^{\text {th }}$ event, there were several articles published in Paris-Dakar including a biography and interviews summarizing the proposed topic of his upcoming conference. In the article aptly titled "Tel est le sujet qui traitera ce soir M. Léopold Sédar Senghor," largely written in interview form, Senghor makes a fleeting reference to Socé. The author writes, "Nous lui prédisons un beau succès et lui rappelons l'affluence considérable qu'avait attiré récemment la conférence de M. Ousmane Socé” to which he

\footnotetext{
9 "La conférence de M. Socé a remporté un succès triomphal à la Chambre de Commerce," Paris-Dakar 3 Aug. 1937: 1.
} 
responds, “Ousmane Socé, c'est un vieux camarade et ami avec lequel j'aimais discuter dans l'ambiance sympathique du Boul'Mich. Dans sa Conférence 'Impressions d'Europe' j'ai reconnu avec plaisir sa clarté et son bon sens habituels." The article's author then makes reference to their divergent ideas writing that "nous percevons que le professeur agrégé et le docteur vétérinaire ne sont pas toujours en communion d'idées."10

The aforementioned article suggests that it was already known that Senghor and Socé did not always agree and this rift materialized more concretely in the following weeks on the pages of Paris-Dakar. Always active in the press, Socé voiced his concerns for Senghor's proposed reforms and several other articles referenced a collective backlash against both Karim and "Impressions d'Europe." It is important to note that Paris-Dakar only published texts that defend and justify Socé's point of view and no explicit support for Senghor's rejection of assimilation appeared on its pages. In an article entitled "Le Danger," published on September 29, Socé responds to Senghor, referencing a potentially dangerous and undesirable side effect of his program. $\mathrm{He}$ explains:

Je veux bien que le paysan africain reçoive une instruction élémentaire où l'enseignement de sa terre et ses moyens de l'exploiter soient prédominants : je veux bien que l'artisan africain n'abdique l'inspiration africaine et que la rénovation de son art se borne à s'appliquer la technique d'Europe à cette inspiration : je veux bien que le bachelier africain connaisse une langue indigène écrite au même titre que l'anglais et que l'allemand.

Mais le danger c'est déjà cet instituteur isolé qui se refuse de présenter des sujets d'élite au C.E.P. sous prétexte d' « éducation paysannale ». Le danger, c'est les hommes qui sont ennemis de notre évolution et qui emploieraient «l'esprit nouveau » à faire « machine en arrière » dans le but d'étouffer l'élite de notre pays. Un tel principe, sous leur pouvoir abouterait à ceci : nos frères noirs sauraient tout ce qui concerne l'Afrique mais ils ignoreraient les connaissances générales de mathématiques, de

10 “Tel est le sujet qui traitera ce soir M. Léopold Sédar Senghor,” Paris-Dakar 4 Sept. 1937: 1. 
philosophie et d'histoire que tout homme des temps présents doit connaître. Ils ne seraient ainsi que des hommes de second plan, avec des horizons intellectuels bornés et c'est là le danger. ${ }^{11}$

Socé expresses hesitant support for Senghor's ideas, but fears the current colonial system may not be able to accommodate his suggested reforms in a way that would foster African advancement. In 1937, with Marcel de Coppet serving as Governor General, the liberalism of the Popular Front was in full effect. The mention of "l'éducation paysannale" was likely referencing the debate surrounding l'École rurale populaire and the collective fear, among the African elite, of the reforms being instituted in urban areas. $^{12}$ Though five years before Dakar-Jeunes, Socé's concerns foreshadow Vichy policy changes that seek to limit access to higher education across the territory, not just in rural areas.

Additional responses addressing Socé's speech include an article by Abdoulaye Sadji as well as contributions from more obscure authors who commend his message while giving insight into the nature of the controversy. In his article, "Utopie et Réalité," Sadji vocally supports Socé's call for the education of African women enumerated in “Impressions d'Europe.” Both Socé and Sadji disapprove of the overwhelming lack of focus placed on women's education in indigenous culture:

Une question qui n'a rien de nouveau et en soi parait enflammer la jeunesse intellectuelle sénégalaise depuis que notre ami et compatriote Ousmane Socé a, dans une conférence très appréciée, mis en relief l'une des entraves à notre évolution : le manque total de culture et d'éducation de la femme indigène. ${ }^{13}$

\footnotetext{
${ }^{11}$ Ousmane Socé, "Le Danger” Paris-Dakar 28 Sept. 1937: 2.

${ }^{12}$ Léopold Sédar Senghor, "La résistance de la bourgeoisie sénégalaise à l'école rurale populaire" $L e$ congrès international de l'évolution culurelle des peuples coloniaux: Rapports et compte rendu (Paris: Bibliothèque nationale imprimés, 1938).

13 Abdoulaye Sadji, “Utopie et Réalité” Paris-Dakar, 6 Oct. 1937: 2.
} 
Especially in Karim, Socé is overtly critical of many Senegalese traditional values that he feels hinder the social and intellectual advancement of his people: the culture of the samba-linguère, academic motivation (or lack thereof), the role of the griot, and women's access to education. His selective criticism of Senegalese culture is only further highlighted when juxtaposed with Senghor's more universal praise, and it is this very obvious contrast that likely sparked a heightened critical response from spectators and readers.

The last example appeared in Paris-Dakar on October 29, 1937 and was entitled "M. Ousmane Socé et ses admirateurs." The editors of the paper prefaced the two contributions that followed saying "Si M. Ousmane Socé a quelques détracteurs, ses amis et admirateurs semblent l'emporter. Dans les deux articles que nous publions ci-dessous, un de ses amis de jeunesse rappelle l'adolescence laborieuse de son camarade un autre expose et défend les théories de Socé." The first article written by a certain Gaye, focuses largely on the biographical outline of Socé's extensive academic, professional, and literary accomplishments. Gaye does, however, seem to aptly target one of the principal elements of Socé's theory of cultural métissage that was often overlooked by his contemporaries. As seen in "Le Danger" and in "Impressions d'Europe," Socé cites science and technology as Europe's most critical contributions to Africa. In his speech he explains that 'l’Europe est arrivée à une apogée du développement technique et économique [mais que] le progrès moral n'a pas suivi le progrès technique." ${ }^{, 14}$ It is in this juxtaposition of praise and criticism where one finds Socé's philosophy of cultural métissage in action. Gaye explains:

\footnotetext{
${ }^{14}$ Ousmane Socé, “Impressions d’Europe,” Paris-Dakar 6 Aug. 1937: 2.
} 
Ousmane Diop, dont l'esprit était en continuelle réputation pour s'assimiler tout ce qui est du domaine du savoir, excellent élève, a toujours été un des meilleurs de sa classe où il a souvent pu conquérir la première place.

The distinction of the "assimilation du savoir" is more representative of the kind assimilation that Socé is promoting. A huge believer in education, Socé feels that only through a comprehensive multi-disciplinary approach to learning, can Africans hope to positively evolve. The debate between he and Senghor is thus how to create an education that reconciles the two varying forms of "savoir": the traditional knowledge that makes African culture unique and the European curriculum promoted in French schools. In other words, how much cultural métissage should be fostered in education? Senghor and Socé both acknowledge the importance of a multi-faceted approach; the first source of contention is how to launch said education with Senghor focusing more on the importance of incorporating African culture and language in primary school curriculum.

The article that follows Gaye's defense gives insight into the extent of the fallout as well as the burgeoning camps in favor of each stance. Written by Myrau (neither piece gives a full name) the article entitled "Défense de M. Ousmane Socé" situates the divergent reactions stating "Beaucoup de bruits autour de l'auteur de Mirages de Paris [prouve une] manifestation tonitruante de l'admiration pour O. Socé [ou une] réprobation tapageuse des idées du conférencier de Dakar." He explains the division:

Sadji et Dia ont admirablement montré tout ce que valent Mirages de Paris et son auteur, Birago, Sagnanera et Camera applaudissent lointainement un succès du romancier. Senghor, notre seul vrai humaniste, l'a magistralement défendu et continue de le défendre. Quels sont donc ceux qui critiquent Ousmane Socé ? Ils forment deux groupes, deux catégories d'intellectuels : ceux qui sont volontairement aveugles et ceux qui n'ont pas compris Karim. Les premiers moins nombreux, mais plus dangereux peut-être combattent Ousmane parce que dans Karim et dans sa conférence, ce compatriote a flétri certaines de nos mœurs et 
traditions. Il a trop montré que le griot, le marabout et la femme ruinent la société indigène et entravent son évolution, sa marche vers le bien, vers le beau, vers la vérité.

[...] Karim les amuse comme un gracieux rêve. ${ }^{15}$ Ils ne le méditent pas. Ils le lisent comme ils liraient les contes de Perrault ou les contes bleus de Laboulaye. Ils ne peuvent pas comprendre Ousmane. C'est net et clair.

Ousmane Socé mérite-t-il tous ces reproches? Non, je ne le crois pas. Quelle est la mission de ceux qui écrivent? Alexandre Mercereau va nous répondre : «Faire naitre d'un instinct un sentiment, d'un sentiment une idée, d'une idée une ligne de conduite : développer l'homme dans tous les sens du beau, du bien, voilà la mission de tous ceux qui écrivent $»$. Ousmane a compris cela, il remplit sa mission délicate. Fonctionnaire, il doit servir son pays : écrivain et penseur, il doit combattre les idées périmées, redresser les erreurs et faire bénéficier ses compatriotes du fruit de ses méditations. N'a-t-il pas fait tout cela ? Si, il l'a fait et le fera toujours, toujours.

L'auteur de « Karim » a donc raison de flageller nos vieilles traditions et de souhaiter que tout évolue, tout change chez nous et autour de nous. Nous partageons ses idées.

Ousmane Socé, vous êtes sur la bonne voie. Continuez. ${ }^{16}$

The creation of two distinct camps that began after the Chamber of Commerce speeches directly informs the debate that Socé launches in Dakar-Jeunes five years later. One can also deduce that the press was more supportive of Socé's point of view as there were no articles published in favor of the "anti-assimilation" camp. Several of the same key figures that were active in the press in 1937, also contributed to Dakar-Jeunes, namely Sadji and Mamadou Dia. Dakar-Jeunes was linked to Paris-Dakar and the editors were likely already at ease with the contributions of a certain number of African intellectuals, especially Socé, who had a well-established relationship with Paris-Dakar.

\footnotetext{
15 “Ce sont les insuffisants, les demis-lettrés, selon l'expression mordante d'un des ennemis de la race: ce sont ceux pour qui une évolution signifie simplement transformation, passage d'une forme à une autre forme différente; ce sont enfin les intellectuels formés par les livres dont la niaiserie le dispute à l'insignifiance." Myrau, "Défense de M. Ousmane Socé," Paris-Dakar 29 Oct. 1937: 2.

${ }^{16}$ Myrau, "Défense de M. Ousmane Socé," Paris-Dakar 29 Oct. 1937: 2.
} 
Ousmane Socé re-launched the debate on January 29, 1942 in the fourth issue of Dakar-Jeunes. The article was entitled "L'évolution culturelle de l'AOF," a title vaguely reminiscent of Senghor's "Le problème culturel en A.O.F." with the emphasis placed on the notion of "evolution" in accordance with Socé's ubiquitous focus on the future. In the introductory text that precedes Socé's piece, the editors of Dakar-Jeunes call for the participation of its readers, suggesting that they make their opinions known: "L'article qu'il nous donne éveillera l'attention des jeunes qui nous le prouverons en nous faisant connaître leurs opinions sur la thèse de l'auteur." The debate was presented as a reprisal, inspired by the content of Socé's and Senghor's 1937 Chamber of Commerce speeches as well as the exchange between Socé and Fily Dabo Sissoko that appeared on the pages of Paris-Dakar in early 1939. The editors of Dakar-Jeunes explain the motivation by writing: "Peu avant la guerre, un débat s'était ouvert à ce sujet dans la presse locale et la controverse qu'il suscitait à l'époque s'était close sans avoir épuisé la question ni abouti à une conclusion." Likely unsatisfied with his past attempts to shed light on his philosophies, Socé chose to revisit the debate in hopes of a more conclusive outcome.

Socé opens his article in Dakar-Jeunes by directly referencing the past and outlining his plans for future discussion:

Cependant il n'est pas suffisant que la jeunesse, divisée en deux tendances, soit satisfaite, de part et d'autre, d'avoir bien défendu une position. Une synthèse des diverses attitudes s'impose. Il nous faut la tenter en dégageant d'abord les grandes lignes des théories qui ont été exposées, en essayant ensuite de concilier ce qui vaut dans chacune d'elles pour définir une ligne d'entente. ${ }^{17}$

\footnotetext{
${ }^{17}$ Ousmane Socé, “L'évolution culturelle de l'A.O.F.," Dakar-Jeunes 29 Jan. 1942: 2.
} 
If there were any doubts about the earlier debate being referenced, Socé immediately clarifies the editor's introduction, citing Senghor and contextualizing his divergent views on the subject:

Mon ami Léopold Sédar Senghor, agrégé de l'Université, développait naguère son point de vue en ces termes: "Enseigner aux Noirs d'Afrique des humanités gréco-latines, ce serait méconnaître leur originalité foncière, brimer le génie de leur race, les détourner d'une autre humanité possible, plus conforme à leurs aspirations profondes et à leurs aptitudes congénitales.

Leur appliquer le moule d'une civilisation qui n'est faite ni par eux ni pour eux, pour laquelle ils ne sont pas faits, ce serait commettre une erreur d'orientation, "une véritable injustice pour aboutir finalement au métis culturel, revêtus d'un vernis, inassimilé par ce qu'inassimilable. D'où le devoir de rechercher les directions où s'engage d'elle-même la civilisation des Noirs et de les maintenir dans ces mêmes directions, tout en hâtant leur progrès."

The passage that Socé quotes presents a slightly more radical view than "Le problème culturel en A.O.F.," though all of the ideas conveyed in Socé's chosen citation find themselves integrated into the speech's message. It is impossible to directly attribute this citation to a specific text or speech, yet I have determined that Senghor conveyed these ideas during the "Congrès international de l'évolution culturelle des peuples coloniaux," which was held in Paris three weeks after the event in Dakar. The quote itself can be found in Denis Blanche's "Préface" to the Congress' Rapports et compte rendu, included in a passage dedicated to discounting the undesired dominance of the assimilation debate, led by Senghor, during the three day event. ${ }^{18}$

After referencing Senghor, Socé turns his attention to his heated exchange with Fily Dabo Sissoko:

\footnotetext{
${ }^{18}$ Denis Blanche, Préface, Le congrès international de l'évolution culurelle des peuples coloniaux: Rapports et compte rendu (Paris: Bibliothèque nationale imprimés, 1938) 18. See Appendix for Denis Blanche's full text.
} 
À la même époque dans une qui controverse qui m'opposait à notre compatriote Fily Dabo Sissoko, intellectuel soudanais, celui-là déclarait à la fin d'un article qui m'était adressé que cette position du professeur Senghor était aussi sienne.

In his article, "Autour du Congrès de l'Evolution culturelle des peuples coloniaux," published on January 4, 1939, Socé was critical of “Les Noirs et la culture," Sissoko's contribution to the Rapports et compte rendu. At first glance, Socé was simply announcing the report's publication and providing a quick summary, yet he focused almost solely on Sissoko instead. Socé criticized his selection, claiming that he presented an over-simplified portrait of French Sudanese society (present-day Mali) in which his praise for the past was too strong and his criticism of the current situation, shortsighted:

Ainsi donc, l'auteur a été expressivement sévère à l'égard de ses compatriotes contemporains : au lieu qu'il a été excessivement aimable à égard de ceux du passé. ${ }^{19}$

Socé focused specifically on the juxtaposition of two sections: “Coup d'oeil historique sur la culture des Noirs" and "L'Évolution d'ensemble de la culture des Noirs sous l'influence de la colonisation" of which only his "Croquis soudanais" were published. The first part is a detailed list of important African cultural traits and key Black historical figures; he addresses the issue of writing, folklore and presents brief portraits of several important men from El Hadj Omar to Toussaint-Louverture. Sissoko was presenting proof of Africa's past greatness and continued legitimacy in an effort to undermine arguments supporting the positive impact of colonialism on African society. "Croquis sénéglais" was, in contrast, an acerbic and satirical portrait of the seven most common types of French Sudanese intellectuals: "le type 'Bourgeouis gentilhomme', le type 'Faux-semblant', le type du parvenu, le type du publiciste, le type du dévoyé, le type de

\footnotetext{
${ }^{19}$ Ousmane Socé, “Autour du Congrès de l'Évolution culturelle des peoples coloniaux." Paris-Dakar 4 Jan. 1939: 5. See Appendix.
} 
l'élite." 20 The change in tone is dramatic, though many of Sissoko's works seem to have a certain satirical edge. By mocking the class of "evolués," however, Sissoko implicitly questioned the role of colonial education in Africa. Was access to a European-style education a good thing? Socé thought so and therefore he criticized Sissoko's negative portrayal of intellectual life in Soudan. The Rapports et compte rendu did not include all contributions to the congress, and those included were often excerpts. Though Socé acknowledges that only an "extrait" of Sissoko's work was published, he nonetheless writes:

De nos jours, un homme est-il cultivé s'il est imbu d'humanités classiques, s'il est capable de penser juste et de façon personnelle sur les hommes et sur sa vie? Ou bien l'est-il par l'université de ses connaissances? Ou bien l'est-il si à défaut d'humanités classiques, il connaît bien l'histoire de son pays et de sa race ainsi que les œuvres, peu nombreuses, de ses congénères et aussi quelque connaissance générale ? Ou bien encore un homme est-il cultivé s'il a des connaissances générales suffisantes, du sens esthétique et s'il est capable d'autre part de vertu et pensée originale ?

J'opterais pour cette dernière conjecture car, de nos jours, il est impossible, à l'image d'un Michel Ange ou d'un Bagayoko de loger dans une seule cervelle la somme des connaissances humaines : or toutes sont parties intégrantes de la culture, inséparablement. Dès lors, il y a au Soudan et ailleurs, plus de noirs cultivés que ne pense M. Fily Dabo Sissoko.

Je suis d'accord avec lui dans ses conclusions que « Le Noir doit rester noir de vie et d'évolution ».

L'aframéricain $\mathrm{Cl}$. McKay, l'a aussi affirmé, il y a quelques dix ans.

Mais dans quelle mesure, cette pensée sera-t-elle réalisable dans le brassage actuel des races, des religions des mœurs et des concepts ? Brassage qui, depuis 1850 va toujours s'accentuant dans une précipitation subite du cours de l'histoire humaine.

\footnotetext{
${ }^{20}$ Fily Dabo Sissoko, "Les Noirs et la culture" Le congrès international de l'évolution culurelle des peuples coloniaux: Rapports et compte rendu (Paris: Bibliothèque nationale imprimés, 1938) 120-22. See Appendix.
} 
L'avenir le dira. ${ }^{21}$

Socé concludes with a reference to métissage, the "brassage actuel des races," though also confirms his rejection of full assimilation agreeing with Sissoko's assertion that "le Noir doit rester noir de vie et évolution." This is the very statement Sissoko uses to conclude "Les Noirs et la culture" and is also the overarching theme of this text that promotes an anti-assimilationist message similar to Senghor's.

Sissoko was, not surprisingly, quick to retort and his "Réponse à Ousmane Socé:

A propos du Congrès de l'Évolution Culturelle des peuples coloniaux" was published on January 27. His outrage was immediately apparent as he first outlines the nature of

Socé's article before listing the particular aspects that he found offensive and inaccurate:

Monsieur Ousmane Socé vient de faire paraître un article intitulé :

« Autour du Congres de l'Évolution Culturelle des peuples coloniaux » [...] qui aurait du en toute simplicité et logique s'intitulé « Autour de Fily Dabo Sissoko ».

En effet, cet article comporte deux cent quarante lignes de développement dont cent quatre vingt seize me sont réservées.

J'ai su la nouvelle par un coup de surprise, car le brave Ousmane Socé a négligé l'élémentaire courtoisie de m'aviser ou de m'adresser un numéro.

C'est, au surplus, trop d'honneur pur ma chétive personne, si même comme Ousmane Socé l'avance - je me crois, en traitant de la culture des noirs « le Socle de l'Univers ». En vérité, cela n'a rien à voir avec un Congrès international : et, de telles affirmations sont proprement abusives et témoignent d'un aplomb peu commun.

Vraiment, Dr. Ousmane Socé, là vous avez déçu le lecteur, il était en droit d'attendre mieux de vous.

Vous aviez sous les jeux un recueil de 226 pages, où mon rapport ne figure que pour 7 pages. Vous saviez que ce n'était là qu'un extrait, et vous le dites. Dans ce cas, la probité scientifique requiert de suspendre son jugement jusqu'à plus ample informé. Mais non, vous vous avez jeté sur cette pâture. Dites-moi, sur quels éléments d'appréciation vous

\footnotetext{
${ }^{21}$ Ousmane Socé, “Autour du Congrès” 5.
} 
pouviez vous baser pour jugement sainement un texte tronqué ? A moins que vous ne soyez doué du sens archi-rare de l'ubiquité comme il appert dans vos attaques. Car vous me connaissez si bien que vous savez diagnostiquer mon ascétisme, mes rancœurs et « tutti quanti »!

Non! Ousmane Socé. L'autodidacte que je suis n'a aucune prétention. Les lauriers des universités ne me gênent pas.

Ce qui me paraît grave dans cotre cas, déloyal même, c'est lorsque vous essayez de m'opposer à mes compatriotes soudanais par un double sophisme : 1. en indiquant mes préférences et mes sympathies pour mes ancêtres, mes antipathies pour mes contemporains. 2. en me déclarant, face au Blanc, l'ennemi du Noir dans l'évolution culturelle. ${ }^{22}$

The tone of this exchange between Sissoko and Socé was the most aggressive of the 1937-1942 period. Even though opposing views were expressed, the métissage debate in Dakar-Jeunes maintained consistent collegiality during its run. What is evident from this exchange and important for understanding Socé's motivation for revisiting the debate three years later, was the further establishment of two distinct camps: the assimilationists and the anti-assimilationists. In his response, Sissoko explains that he strongly sided with the ideas that Senghor presented at the congress and that "cette position [antiassimilatrice] est également la nôtre."23 He also included the same quote from Senghor, first cited by Blanche, that Socé later used in Dakar-Jeunes.

Returning to Dakar-Jeunes, in “L'évolution culturelle de l'A.O.F.," Socé presented a clear framework for readers and potential contributors, labeling Senghor and Sissoko’s opposing philosophical views stating, “cette attitude est ce que nous nous appelions la tendance anti-assimilatrice." From the previous citation, it is clear that Socé believes that Senghor is critical of any form of cultural métissage that first dilutes African

\footnotetext{
${ }^{22}$ Fily Dabo Sissoko. "Réponse à Ousmane Socé: A propos du Congrès de l'Évolution Culturelle des peuples coloniaux," Paris-Dakar 27 Jan. 1939: 1.

${ }^{23}$ Fily Dabo Sissoko "Réponse à Ousmane Socé: A propos du Congrès de l'Évolution Culturelle des peuples coloniaux" Paris-Dakar 27 Jan. 1939: 5.
} 
authenticity. In support of his own argument, Socé references antiquity, "les invasions barbares," using another citation taken directly from the Sissoko debate: ${ }^{24}$

C'est une courbe de métissages successifs en fonction des grandes expansions militaires et commerciales de l'histoire; métissages successifs à des degrés variables. Ce que l'étranger donne est en raison inverse de ce que l'indigène a déjà reçu de son propre et qui est viable; un jour viendra peut-être où ce métissage culturel sera interplanétaire. Les cas particulier de cette équation résiderait dans ce fait que parfois le conquérant a été civilisé par l'indigène.

Socé repeatedly uses the past, and most often the ancient past, as seen in his long-running article on Cheikh Anta Diop that appeared in Bingo many years later, as proof of both the inevitability of métissage and its importance in Africa's current evolution. ${ }^{25}$ Focusing on the notion of exchange by underlining the fact that it is not always the conqueror that "civilizes" but also the reverse, Socé seeks to further highlight the reciprocity of his proposed philosophy using history as supporting evidence. He explains that civilization in Africa is becoming "eurafricaine" or "franco-africaine" with a focus on the natural occurrence of such a phenomenon. He states, "La nôtre, la volonté des peuples mis en facteur, sera eurafricaine, précisément franco-africaine. Pour qu'elle soit autre, il eut fallu que la roue du destin marchât dans un autre sens."26 One will see, however, that this reasoning does not suffice for many who still side with Senghor's more radical views. It is important to note that Socé himself uses the term "la tendance anti-assimilatrice" to label his opponents. If his opponents are anti-assimilationist, the juxtaposition suggests that he must consider himself assimilationist by default. However, the distinction is

\footnotetext{
${ }^{24}$ Ousmane Socé, "Les noirs et la culture: Réponse à M. Fily Dabo Sissoko." Paris-Dakar 10 Feb. 1939: 5.

${ }^{25}$ See Chapter 1.

${ }^{26}$ Ousmane Socé "L'évolution culturelle de l'A.O.F" Dakar-Jeunes 29 Jan. 1942: 2. This is also a direct quote from his last reponse to Sissoko. Ousmane Socé. "Les noirs et la culture: Réponse à M. Fily Dabo Sissoko.” Paris-Dakar 10 Feb. 1939: 5.
} 
much more nuanced and each intellectual likely defined assimilation differently. When all of these ideas are expressed in French rather than an African language, one has to acknowledge that some degree of métissage has already occurred. Moreover, the debate was much less on the existence of métissage in AOF, and more focused on what kind of cultural métissage to promote in the future.

Before addressing select contributions from Dakar-Jeunes, it is important first to situate the debate historically as understanding of the climate in Vichy AOF is essential for understanding why Dakar-Jeunes, a cultural publication, was able to exist during a time that would seem to be hostile to the kind of progressive and candid cultural essays that appeared on its pages.

\section{French West Africa and Vichy Rule}

Marcel de Coppet's reign as Gouverneur-Général of AOF was relatively shortlived as was the Popular Front-inspired liberalism he espoused. De Coppet was dismissed from his post and returned to Paris in October 1938 after he was critiqued, first for his lenient response to the increase in strikes that occurred in AOF after trade unions became legal in 1936 and, finally in response to his conversely severe repression of the Thiès railway strike of $1938 .{ }^{27}$ Some of reforms he helped put in place, however, never seemed to fully take hold, with such strikes virtually disappearing after his removal from office. That said, one cannot discount the lasting effect this increased liberalism had on Africans' relationship with the colonial government, especially in regard to the personal liberties France ultimately chose to grant or withhold from its subjects in the years to come. $^{28}$

\footnotetext{
${ }^{27}$ Ruth Ginio, French Colonialism Unmasked, 5.

${ }^{28}$ Chafer, The End of Empire 38.
} 
Léon Cayla replaced De Coppet as Gouverneur-Général and the more liberal policies of Popular Front years were deliberately and consistently scaled back. By the outbreak of the Second World War, all of the Popular Front's reforms were abolished. The Vichy government would then take an even more conservative approach to colonial rule, rescinding previously granted rights such as the four communes' representation in the National Assembly ${ }^{29}$ while bringing naturalization of Africans to a near halt during the war years. ${ }^{30}$ This is one example of the seemingly "give and take" approach to colonial policy that came to mark the last decades of French colonial rule. ${ }^{31}$ The lack of continuity regarding freedoms granted, withheld, or even revoked from colonial subjects is one factor that many scholars attribute to the Empire's eventual demise, as France's inability to uphold its stated ideological credo of "liberty, equality, brotherhood" became increasingly apparent. Not only was France's ideological message compromised, but its military's reputation was also dashed after the swift and crushing defeat to Germany in 1940.

However, Pétain was quick to reassure colonies of France's uncompromised leadership and on June 25, 1940 immediately after signing the Armistice, he explained, "I

\footnotetext{
${ }^{29}$ The seat held by Blaise Diagne from 1914 - 1934.

${ }^{30}$ Ruth Ginio, "Vichy Rule in French West Africa: Prelude to Decolonization" French Colonial History, vol.4 (2003) 209.

${ }^{31}$ Tony Chafer suggests that the Popular Front's reforms, even though short-lived, were seen as a manageable way to confront the contradictions inherent in the colonial system. He explains: "What the Popular Front was offering was the carrot of assimilation and a stake in the colonial system to the small elite of French educated Africans, and association, with its implications of gradual modernization but without a fundamental transformation of tradition society, to everyone else. It was a pragmatic political solution to the contradiction inherent within the colonial 'problem' confronting the government: how to humanize an essentially repressive and authoritarian colonial regime without changing it so much as to undermine its stability. As a long-term answer to the question of the ultimate aim of colonialism, it was unsustainable, if for no other reason than that it wholly underestimated the force of attraction of the French model for Africans. But it was effective as a holding operation, buying time for the French government by introducing modest reforms while holding out the prospect of further reforms in the future. This was to be a recurring feature of French African policy after the war." Tony Chafer, The End of Empire in French West Africa: France's Successful Decolonization? (Oxford: Berg, 2002) 37.
} 
was no less concerned about the colonies than about metropolitan France. The Armistice maintains the bonds that unite us with them. France has the right to rely upon their loyalty." ${ }^{32}$ In periods of military defeat or political difficulty, France often looked to its Empire as the crowning symbol of its cultural, ideological, and economic influence around the world - the symbol that confirmed the nation's greatness, even in the face of defeat. As early as the 1871 defeat in the Franco-Prussian War that resulted in the tragic loss of Alsace-Lorraine, one can trace more active colonial expansion and policy change to periods of political upheaval and turmoil in metropolitan France. The terms of the Armistice left France with full control of its Empire, and in a political climate defined by capitulating to a seemingly omnipotent vanquisher, this relative autonomy vis-à-vis the colonies became ideologically significant and one of the only remaining tangible vestiges of France's former unoccupied glory. Ginio explains:

France had just been humiliated by the loss of two-thirds of its metropolitan territory, but Pétain had secured France's vast Empire in the Armistice agreement, and this was a vital source of consolation. Pétain regarded the Empire as his most precious diplomatic card. It gave Vichy France exactly what it most lacked: huge tracts of territory, manpower, resources, and prestige. It would also have an essential future function in the post war world, a world in which Germany would be the dominant power. The Empire was expected to give France a respectable status in that world, notwithstanding its inferior position resulting from defeat.

The symbolic importance of the Empire cannot be underscored. Not only did France need to "rely upon [the colonies'] loyalty" for morale, but to maintain the favorable economic conditions that colonial policy inherently fostered. Social and racial hierarchies, however, were essential in maintaining order, and news of France's swift defeat and successive occupation could compromise its authority as the omnipotent and unflappable colonizer. Africa was not only morally important for a nation mourning its

\footnotetext{
${ }^{32}$ Ginio, French Colonialism Unmasked 1.
} 
autonomy but militarily strategic as well. As Charles De Gaulle began his opposition to Vichy rule from exile in Great Britain, garnering support in North and West Africa was a top priority. Governor General Cayla had immediately voiced support for De Gaulle in the days leading up to and after the Armistice, but was forced to retract his comments by Vichy authorities. ${ }^{33}$ He was then quickly removed from his post by the Vichy Council of Ministers and replaced by a likely supporter, Pierre Boisson, who had been serving as the Gouverneur-Général of French East Africa. With Boisson in power, a series of military events, though often missteps, would firmly place AOF on the side of Vichy and set the scene for a well-orchestrated propaganda campaign designed to ensure support from citizens and subjects residing in the associated colonies during the war.

Africa contained territory that was hotly contested by both the Allied and Axis powers and De Gaulle sought to immediately garner support in the French colonies with some immediate success. As early as June 26, 1940, Felix Éboué, the then Governor of Chad, sought to create a unified African bloc that would reject the Armistice and side with De Gaulle and the Allies. This was a period of much political maneuvering as sides were taken and lines were drawn, but Boisson, who had since been appointed to the newly-created post of High Commissioner for French Africa, ${ }^{34}$ did not yield to De Gaulle's calls or make any substantive response to Eboué either. ${ }^{35}$ Boisson's swift promotion to High Commissioner shows the staunch desire of Vichy authorities to provide him with the incentive to remain loyal to the cause, to fiercely protect the territory, and to ensure that AOF remained a Vichy stronghold in the face of mounting

\footnotetext{
${ }^{33}$ Janet Vaillant, Black, French, and African: A Life of Léopold Sédar Senghor (Cambridge : Harvard University Press, 1990) 184.

${ }^{34}$ Pierre Ramognino, L'Affaire Boisson: Un proconsul de Vichy en Afrique (Paris: Les Indes savantes, 2006) 79.

${ }^{35}$ Ramognino 79.
} 
Gaullist pressure. Boisson's allegiance would soon be evident, as he remained devoted to Vichy even when AEF officially sided with De Gaulle on August 27, $1940 .{ }^{36}$ He was able to successfully shelter AOF from fully siding with De Gaulle and the Allies for nearly three years before being ousted and forced to resign by De Gaulle himself on June $23,1943 .^{37}$

Several events that took place in North and West African in the months immediately after the Armistice served to strengthen Boisson's already keen support for Vichy and provide ample fuel for his impeding propaganda mission. Firstly, there was the British naval attack on French warships based off the coast of Mers-el-Kébir, Algéria on July 3, 1940 during which the British navy launched an attack killing 1,297 French sailors and sinking 3 out of 4 of their warships. Then on July 8, 1940, the state-of-the-art French battleship the Richelieu, which had taken refuge in Dakar, was seriously damaged by British torpedo bombers launched from the aircraft carrier Hermès. ${ }^{38}$ The final straw, that strengthened the centuries-old French and English rivalry and catapulted De Gaulle and Britain to the status of enemy-of-AOF in the same breath as Germany, was the Gaullist forces' failed attack on Dakar in September of 1940. Lasting for three days from September 23 to 25, De Gaulle backed by several British warships and a small force of Free French troops, tried and failed to liberate AOF from Vichy control and unite it with the already Gaullist AEF. He expected little resistance, dropping Gaullist propaganda leaflets by plane and sending a small boat to shore with an emissary charged to discuss a peaceful surrender with Boisson. Instead of being welcomed, he and his team came

\footnotetext{
${ }^{36}$ Ramognino 94.

${ }^{37}$ William Hitchcock, "Pierre Boisson, French West Africa, and the Postwar Epuration: A Case from the Aix Files," French Historical Studies (24:2, Spring 2001) 320, 335.

${ }^{38}$ Hitchcock 316.
} 
under fire, but were able to narrowly escape and reunite the awaiting flotilla. When peaceful negotiations seemed unlikely, British forces opened fire, but troops in Dakar responded with heavy assault from shore batteries. Gaullist forces then tried to come ashore at Rufisque but were again thwarted and had to retreat. Ultimately, all attempts to take the port of Dakar failed and the British and Gaullist forces were forced to retreat to the Ivory Coast in what was considered one of De Gaulle's greatest military failures of the war.

After the war, Pétain justified his actions in terms of playing "a double game," claiming that he only embraced collaboration to "ease the burden of German occupation and buy time for the armed resistance." William Hitchcock in his article "Pierre Boisson, French West Africa, and the Postwar Epuration: A Case from the Aix Files," states that Boisson's rule in AOF is "a colonial version of this thesis." 39 A fervent nationalist and true believer in the civilizing mission, Boisson sought to defend AOF from any and all foreign occupation. The idea of ceding control to the British, France's largest imperial rival, was as repugnant to him as German occupation, especially after the series of British attacks on French holdings. His slogan, "neither an Englishman nor a German in the AOF," informs much of the protectionist policy and propaganda that followed. Boisson sided with Vichy as it was the closest and thing to the France of old and he knew the potential danger of diluting French authority in the colonies. ${ }^{40}$

In the face of mounting Gaullist pressure, it was essential to continue to promote French sovereignty while underscoring the role of German occupation in post-Armistice policy. If France's colonial subjects fully understood the extent in which its omnipotent

\footnotetext{
${ }^{39}$ Hitchcock 309.

${ }^{40}$ Hitchcock 326.
} 
leader was under foreign control, French authority would be greatly compromised. For Boisson, promoting the message of France's continued legitimacy and loyalty to its subjects was essential for protecting the Empire. To maintain rhetorical and political supremacy, authorities in AOF had to strictly control the flow of information to counter any message that would compromise the image of France as the benevolent and invincible "mère-patrie." In AOF, Great Britain was the easy scapegoat after its role in the attack on Dakar as well as Mers-el-Kébir, making it AOF's premier enemy and, likewise, authorities vilified De Gaulle for siding with a nation who had just launched several attacks on French territory. Germany could be all but eliminated from the discussion, thus greatly underscoring France's actual defeat and setting the stage for an effectively evasive propaganda campaign. After the relative turmoil of the summer of 1940, Pierre Boisson in the role of high commissioner of French Africa, would fully embrace Vichy ideology promoting it fervently in thought and deed with the local press becoming the chief mouthpiece.

Ruth Ginio, an authority on AOF during the Vichy years, has done extensive research on the policy changes that occurred and the propaganda used to promote Vichy's National Revolution philosophy. The flow of information in AOF had to be manipulated to underscore France's defeat and reassure its subjects that the nation was still "powerful enough to maintain control of their lives." ${ }^{41}$ Though the more overtly racist policy changes that occurred simultaneously are important in understanding the watershed that his tumultuous period helps to incite, this discussion focuses on the propaganda used to target the educated African elite, who were seen as indispensable in propagating France's new traditionalist message in the colonies. Ginio explains, "As often happens in

${ }^{41}$ Ginio, "School Children” 291. 
totalitarian regimes, Vichy propaganda in France strove to enforce uniformity, embrace an idealized view of the past, and propagate organic metaphors of unity." ${ }^{42}$ The manifestation of this in AOF as exemplified in Dakar-Jeunes is remarkable. The editors of the weekly newspaper systematically toed the Vichy party line, focusing in nearly every issue on France's historical greatness, traditional French and African agrarian values, the importance of physical fitness, with very little mention of actual wartime turmoil. Rarely does Germany or Britain grace the pages of Dakar-Jeunes, and by only mentioning the publication's existence without delving into its content, scholarship on Vichy AOF misses what appears, especially in early issues, to be the print manifestation of all of Vichy's reformed values.

Vichy propaganda permeated all information channels in AOF. A multifaceted approach that included widespread censorship, control of the press, and pro-Vichy interpretation of events, ensured that the information reaching the public was favorable to the cause. Boisson additionally created the Service MA (the Service des menées antinationales), which mirrored a similar organization in metropolitan France that served to intercept material that could in any way compromise Vichy authority. ${ }^{43}$ The organization intercepted dissident propaganda, investigated hundreds of civilians, and combed through mail with the hope of limiting the inflow of information that could undermine the image of France that was so meticulously portrayed in the press loyally serving Vichy interests. ${ }^{44}$ All newspapers were suspended except for the few that could be controlled and manipulated as mouthpieces of the Vichy cause including Paris-Dakar, Le Sénégal, La Côte d'Tvoire Française and of course the weekly publication Dakar-

\footnotetext{
${ }^{42}$ Ginio, "School Children" 310.

${ }^{43}$ Hitchcock 323.

${ }^{44}$ Ginio "Vichy Rule in French West Africa" 213.
} 
Jeunes. By controlling the press, the administration could provide their official interpretation of events, while giving a favorable spin on daily headlines.

In addition to the press, the administration diffused propaganda through radio, cinema, books, brochures, lectures, and photographs. Ceremonies praising France, Pétain, or promoting new National Revolution symbolism served to bolster public support and reduce uncertainty with requisite nationalist fanfare and pomp. National imagery was reassigned and Joan of Arc replaced the Marianne of the past. It was thought that both French and Africans could better identify with her age, and the patriotic sacrifice she epitomized made her a more relevant and desirable national symbol for the times. ${ }^{45}$ The new regime, who rejected the France of the Third Republic, required a new figurehead to complement its leader who was portrayed in the colonies as a paternalistic and benevolent figure, the "Papa Pétain" who cared deeply about his "children," his colonial subjects. Anti-Semitic propaganda was conversely negligible in AOF due to the very small number of Jews who lived in the region. ${ }^{46}$ Though the National Revolution philosophy was a product of the Vichy administration in France, related propaganda was tailor-made for the colonies with their specific challenges in mind. The notion of the "return to the earth" and the agrarian ideals of an unfettered past would have a different effect in AOF than it would in France. Dakar-Jeunes exemplifies how a concept meant to deter African social mobility and limit the growing class of "evolués," would promote the more radical, anti-assimilationist thought that had emerged during the previous decade: thought that had undeniably nationalist leanings.

\footnotetext{
${ }^{45}$ Ruth Ginio, "Les enfants africains de la Révolution nationale: la politique vichyssoise de l'enfance et de la jeunesse dans les colonies de l'AOF (1940-1943)" Revue d'histoire moderne et contemporaine, T.49e, No. 4 (Oct. - Déc. 2002) 152.

${ }^{46}$ Ginio "School Children" 299.
} 
This policy shift towards tradition reflected a simultaneous de-emphasis on erudition. Education policy in AOF no longer sought to promote secondary education for Africans, instead choosing to largely limit them to primary schooling. Ginio explains:

En outre, les valeurs prônées par Vichy - la famille, le travail, le retour à la terre, la tradition - sont perçues comme des valeurs fondamentales de la société africaine que l'on s'inquiète justement de voir disparaître sous l'effet de l'exposition des enfants à l'éducation française républicaine [...] l'administration coloniale peut donc se contenter d'expliquer aux populations africaines, et notamment aux enfants qui fréquentent les écoles, que le nouveau régime métropolitain encourage précisément les valeurs qui sont celles de la société africaine traditionnelle. ${ }^{47}$

The emphasis that had been placed on the creation of the class of "évolués" along with the increase in liberties granted (especially to the residents of Senegal's four communes) during the Popular Front years were seen as yet another danger to French colonial authority, and putting a halt on such social mobility became a Vichy priority. The way in which Vichy authorities sought to achieve this goal, however, is remarkable. The motivation for such policy changes was based on an increasingly severe promotion of the racially driven ideals that were paramount for maintaining the strict colonial hierarchy necessary to ensure French rule. Yet the rhetoric seen in the press promoting these traditionalist ideals is notably gentle. When combing through the issues of DakarJeunes, one can find contributions that explicitly reference Africans' intellectual inferiority, but at first glance many of the articles (whose authors frequently have a European name) are inoffensive portraits of rural life, traditional existence, and even religious ceremonies. ${ }^{48}$ If policies were harsh, the rhetoric strove to maintain the role of France as the generous "mère-patrie" with Pétain as the benevolent "Papa."

\footnotetext{
${ }^{47}$ Ruth Ginio, "Les enfants africains" 141.

${ }^{48}$ After the debate on cultural métissage comes to an end, Charles Béart, writes an editorial piece that seeks to reign in the contributors of Dakar-Jeunes and restablish authority. In his article entitled "A propros
} 
In her article entitled "Marshal Pétain Spoke to School Children: Vichy Propaganda in French West Africa, 1940-1943," Ginio shows how Vichy developed propaganda with tradition being the vehicle used to promote its legitimacy. African representatives were charged with promoting the Vichy cause in their native communities and tracts were distributed with messages referencing Islam or traditional social roles. Such authentic voices were used in rural areas where inhabitants may be less effectively targeted by the traditional print media explicitly destined for "l'élite intellectuelle." ${ }^{49}$ For example, Ginio cites a pro-Vichy, anti-British pamphlet said to be written by a "Muslim of Tukolor origin who was born in French Guinea but grew up in the British colony of Sierra Leone," in which the author describes his pilgrimage to Mecca and his eventual choice to return to AOF:

Entering French territory, I saw that there was no suffering in the French colonies as the British claimed. I saw that the Germans did not rule the French colonies as the British wanted us to believe. After being able to appreciate exactly the fate of the natives of Sierra Leone, I chose the Marshal who, whatever the British may say, protects and guards our colonies for France. ${ }^{50}$

By distributing its message through the guise of tradition, Vichy was able to package their agenda in a way that would be palpable and even appealing to native populations. The supposed African authorship as well as the author's reasons for his travels (his pilgrimage), serve to add legitimacy to his claims. With the choice of both colonizers'

d'une littérature indigène d'expression française," Béart condescendingly explains at length why Africans are not capable of producing true "literature" in the European sense. Referencing the existence of Africa's rich oral heritage but Africans' inability to transform its contents into an African literature in its own right (Béart's work at William Ponty involved documenting folklore, traditions, and music), he states that "la matière ne manque pas, vous n'êtes pas en mesure de la mettre en oeuvre." Charles Béart "A propros d'une littérature indigène d'expression française" Dakar-Jeunes 18 Jun. 1942: 4.

${ }^{49}$ Brief ads on the pages of Dakar-Jeunes address the target audience directly: "Élite intellectuelle de l'Afrique Noire, lisez chaque jeudi Dakar-Jeunes" 25 Jun. 1942: 8.

${ }^{50}$ Ginio, "School Children" 300. 
territories, the author communicates to his readers how he "easily" chooses France, largely to due it's benevolent leader.

Lastly, Ginio describes the recruitment and use of Africans as messengers for the colonial administration. Seydu Nourou Tall, son-in-law of El-Hajj Malick Sy, the leading Tijani marabout in Senegal, earned himself the unofficial title of "marabout of African soldiers" by transmitting the Vichy message to African troops returning to their villages. By communicating the values of the National Revolution to young men returning home, the administration could further promote their message in rural areas. These African messengers could more effectively reach and target populations through the use of their native languages with the added legitimacy of a familiar face reuniting with his people at long last. According to Ginio, when Tall could no longer deny France's defeat to Germany, he explained that Pétain signed the Armistice to save France and make it stronger. Tall also "encouraged soldiers to boost their agricultural activity" while cautioning them against sharing the fact that France had been defeated by Germany. He promoted the National Revolution credo by asking soldiers returning home to "work hard and be with their families" while using the Quran itself to promote Vichy values. Tall explained how the notions of "Travail, Famille, Patrie" had long been present in the Quran, quoting one particular Hadith which read "the love of the Motherland stems from faith," in order to exemplify the conformity of the Vichy message with all aspects of West African daily life including Islam, traditional family structures, communitarian values, and agricultural production. ${ }^{51}$ Dakar-Jeunes seeks to do the same in print with weekly rubrics designed to focus on traditional African values with the

\footnotetext{
${ }^{51}$ Ginio, "School Children” 308-309.
} 
added inclusion of lengthy sports coverage promoting athleticism and physical activity, another primary tenet of the National Revolution values.

\section{Dakar-Jeunes and Cultural Métissage}

Understanding the way in which Vichy used propaganda to diffuse its message to diverse audiences is key to contextualizing the political climate that gave birth to a publication like Dakar-Jeunes. A vehicle of propaganda targeting "l'élite intellectuelle de l'Afrique Noire," Dakar-Jeunes hit newsstands every Thursday from January 8, 1942 through February 25, 1943. It was a very different publication from Paris-Dakar, its parent paper that has been widely cited in previous chapters. Unlike Paris-Dakar who targeted the general reading public, both French and African, Dakar-Jeunes was composed for the educated African elite with content specifically designed for this niche. The colonial administration feared that its ties to an occupied motherland could jeopardize its authority in AOF. Gouverneur-Général Boisson knew that higly-educated Africans, many of whom who had studied at prestigious colonial schools like William Ponty or Lycée Blanchot, had to be targeted and swayed to its side gently and, most importantly, through the guise of respect. It is through this seemingly feigned respect that the publication became a forum for Africa's best and brightest: Ousmane Socé, Mamadou Dia, Abdoulaye Sadji, Fara Sow, and Ouezzin Coulibaly were among the contributors to the cultural métissage debate and Amadou Hampâté Bâ and Bernard Dadié published folklore.

The newspaper's format remained largely unchanged during its run with the exception of an initial increase in pages from 8 to 12 in the tenth issue and the return to 8 pages in issue 46. To the left of the newspaper's title, there is always a small text box 
containing an inspirational quote or brief reflection from Pétain with the heading "Le Maréchal dit aux jeunes" or "La consigne du Maréchal." The first issue's reads, "Vous êtes l'espoir de la France nouvelle. C'est sur vous que repose son avenir, AYEZ CONFIANCE... NOUS VOUS AIDERONS." These weekly messages served to further promote the image of Pétain as the benevolent "Papa," who cared deeply about the Empire and the interests of its subjects. By promoting collective confidence in France's leader, authorities could underscore the harsher realities of defeat and collaboration. Promoting the message that AOF could count on Pétain and France's loyalty, support, and sovereignty was a priority of all Vichy propaganda.

The first article of the publication is a short piece by Boisson himself entitled "Dominer les événements au lieu de les subir" in which the Gouverneur-Général gives context to Dakar-Jeunes' symbolic purpose:

Que les jeunesses africaines m'entendent. J'ai dit souvent, tellement ma conviction en est profonde, que l'Afrique jouera un rôle de premier plan dans le redressement français.

L'Afrique, c'est le blanc et le noir associés.

Que les deux jeunesses africaines apprennent à se connaître, apprennent à s'apprécier, apprennent à s'aimer.

Qu'elles apprennent à s'épauler, à conjuger leurs efforts. La France veut faire à la jeunesse Noire une large place dans la France africaine.

Que la jeunesse noire s'instruise pour la tenir et surtout qu'elle s'attache à se pénétrer de cette notion - une des plus fécondes de la tradition française - que toute vie se grandit et s'anoblît d'abord et surtout par l'honnêteté professionnelle, la pratique quotidienne des devoirs d'Etat, la soumission constante à l'honneur du métier. ${ }^{52}$

Readers can remark the association-style rhetoric that this opening article conveys.

Boisson prefaces Dakar-Jeunes as a publication of sharing and exchange and in many

\footnotetext{
${ }^{52}$ Pierre Boisson, "Dominer les événements au lieu de les subir" Dakar-Jeunes, 8 Jan. 1942: 1.
} 
ways it was just what it claimed to be. The difficulty is thus reconciling its expressed purpose with the harsher realities of the Vichy program. This can be explained two-fold. Firstly by understanding the publication's target audience, explicitly referenced in texts promoting readership: "Elite intellectuelle de l'Afrique Noire, lisez chaque jeudi DAKAR-JEUNES." ${ }^{53}$ Secondly, by understanding the content and purpose of the National Revolution values that Boisson sought to promote actively in AOF. It is important to note, however, two key points of Boisson's ingratiating opening statements: the notion of "une large place" given to African youth as well as his closing statement referencing "la soumission constante à l'honneur du métier." It is in these statements that readers can glean the lingering subversion of his message. "Une large place" is vague and unqualified without details explaining the roles he envisioned, and the closing statement referencing submission to one's work, highlights the continued importance of production (agricultural or otherwise) in service of France that was even more important during wartime.

Each successive issue opens with a short article written by the editors and signed "DAKAR-JEUNES" referencing some aspect of French culture with an accompanying image. Topics range from the "Le travail bien fait" describing the importance of thoughtful and skilled craftsmanship in France and in Africa with the suggestive closing message of "nous sommes sûrs que vous tous, nos jeunes d'Afrique, vous êtes bien les frères de ceux de France" to brief portraits of Bordeaux, Reims, or other French regions and cities. ${ }^{54}$ Almost all are composed in a poetic tone, singing the praises of France's past and continued greatness or the richness of the nation's heritage, all while referencing

\footnotetext{
${ }^{53}$ Dakar-Jeunes, 25 Jun. 1942: 8.

${ }^{54}$ Dakar-Jeunes, 22 Jan. 1942: 1.
} 
the importance of the role of the nation's youth (both French and African) in lifting up "la patrie" in its time of need. There is little explicit mention of the prevailing situation, placing the focus, rather, on national pride and duty.

The opening article was generally followed by a series of brief current events and "faits divers" found under the heading "Le saviez-vous?" Though there was some slight variance in organization and headings, readers of Dakar-Jeunes could count on the inclusion of several rubrics in the same general order. These include "Notre Afrique," “Connais-tu la France?," "La Vie Sprituelle de l'A.O.F.," "Le Relais du Sport,” "Courir...Sauter...," "Lancer...Nager...," "Plein Air," "Jeunes en Action," and "Héros et Bâtisseurs de l'Afrique Française." Though the editors would frequently insert other rubrics with content ranging from music, games, and riddles to special portraits of the Empire outside of AOF, these pages were the most consistently present. Nearly half of every issue was dedicated to sport with detailed accounts of sporting events in both France and AOF. "Plein Air" and later "Jeunes en Action" generally focused on youth activism and scouting, one of the National Revolution's primary means of indoctrinating French and African youth and instilling them with their core values. By promoting scouting or other nationally sponsored youth organizations such as the "Association Catholique de la Jeunesse Française" and the newly created "Gardes d'Empire," Vichy sought to reach the audience it deemed most integral to its success. Not only did youth best embody the Vichy values that placed such significant emphasis on health, physical fitness, and moral fortitude, young people were also more likely to be swayed to subscribe to the new program. ${ }^{55}$ Returning to Boisson's opening article, readers can immediately see the primary importance of this message. The Gouverneur-Général

\footnotetext{
${ }^{55}$ Ginio, "School Children" 301.
} 
explains, “Ce n'est pas dans le plaisir mais c'est dans l'effort qu'on s'épanouit, dans l'effort physique qui assouplit les muscles et fait partout marcher en vainqueur." This notion is further supported by the publication's focus on sport and scouting as well as the promotion of the value of hard work and dedication to one's chosen trade. ${ }^{56}$

The rubrics "Notre Afrique" and "La Vie Spirituelle de l'A.O.F." focused explictely on African culture and included frequent contributions from African writers and intellectuals. Perusal of other concurrent publications suggests that Dakar-Jeunes' cultural focus was exceptional and a form of propaganda whose goal was to ingratiate the educated African elite to the Vichy cause. "Notre Afrique" and "La Vie Sprituelle de l'A.O.F." not only hosted the discussion on cultural métissage, but included exposés on traditional life in AOF, regional portraits and descriptions, tales, folklore, and serial short stories as well as articles on dance, music, and theater. Taken out of context, their content was in fact underlining "les valeurs culturelles du monde noir," the definition that Senghor attributed to the Negritude movement. Though it is important to note that the climate in which these writings occurred was not favorable to African advancement, the subjects addressed complemented the Pan African social movements that had been brewing for at least a decade in France and drew on themes that shaped important discussion on culture in AOF as early as 1936. The masterminds of Vichy propaganda failed to perceive the danger of this forum, because the motivation driving the promotion of traditional values was based on the core belief of the inferiority of African culture, art, and music and an increased focus would only serve to ensure African subjugation.

Though countless themes found in Dakar-Jeunes deserve further investigation, this study will focus on the discussion of cultural métissage that graced its pages from

\footnotetext{
${ }^{56}$ Boisson, "Dominer [...]" 1.
} 
January 29 to June 11,1942. Though not all relative publications fall under, "L'évolution culturelle de l'A.O.F.," the original heading launched by Ousmane Socé in the forth issue of the publication, the theme itself can be traced to June even if the official announcement of its end appears on April 30. The notice states "Nous pensions terminer notre enquête sur l'évolution culturelle de l'A.O.F. dans ce numéro. Quand de nouveaux envois nous parvenus, leur intérêt nous engage à les publier, afin de nous permettre de faire, en conclusion, la synthèse la plus complète." ${ }^{, 57}$

Before discussing several examples of the responses that were inspired by Socé's call, an article from the tenth issue gives insight into the singularity of the publication while also providing an excellent résumé of the opposing camps' points of view up until this point. In the article entitled "La jeunesse se confie à Dakar-Jeunes, " Fara Sow chronicles the extensive contribution of his compatriots, likely in order to further promote active contribution and readership. He provides a summary of important articles as if he were addressing new readers or subscribers who may have missed the first issues, with the primary focus placed on Socé, Senghor, and Sissoko's differing opinions. He opens the article with a simple yet poignant observation: "Dakar-Jeunes, journal nouveau, esprit nouveau. La jeunesse africaine a enfin voie au chapitre. Elle a déjà envoyé à son journal quelques articles qui ont fait sensation." The emphasis on "enfin" serves to confirm the new and exceptional nature of this print forum for African intellectuals.

After summarizing Socé's proposed debate as "une sorte de bataille rangée," he closes with thoughts suggesting admiration for Senghor and Sissoko's idealism without an explicit endorsement of either. He manages, however, to underline a key element of

\footnotetext{
${ }^{57}$ Dakar-Jeunes 30 Apr. 1942: 3.
} 
Dakar-Jeunes' role in fostering nationalist currents as well as the dangerous oversight that marked the Vichy program's campaign to ingratiate the educated African elite:

Le point de vue de Léopold est une utopie, la belle utopie d'un jeune homme très fin lettré qu'un amour excessif du pays natal a poussé à des conceptions chimériques pour sa race. Surtout cette utopie nous est très chère et par là même nous est d'une certaine utilité. Elle ne manque pas, en effet, de réconforter et d'exalter un bon nombre de jeunes et leur faire prendre conscience de leurs possibilités. ${ }^{58}$

The notion of a "prise de conscience" is essential in understanding how Dakar-Jeunes was a misstep for the Vichy propaganda machine. Rather than promoting a form of traditionalism that would redirect attention to a more agrarian existence devoid of the kind of possibility African intellectuals were referencing in their articles, Dakar-Jeunes became a rallying call that inspired its readers and contributors to want more. The forum energized Africans by giving them a voice and more importantly a platform to discuss themes central to their current and future existence in a bipolar world.

Returning to the debate itself, the first response to Socé's January $29^{\text {th }}$ call for participation appeared two weeks after the original article. The editors of Dakar-Jeunes generally included the heading "L'évolution culturelle de. l'A.O.F." with any text contributing to the discussion, easily directing readers' attention to the topic at hand. Written by Kalande and entitled "Une mise au point," the article highlights weaknesses in Socé's proposed program while simultaneously referencing Africa's predominance in the history of Civilization, citing Egypt and Benin as examples of great empires. He faults Senghor and Socé for being too general when referencing "African civilization" as they both are ignoring difficult realities as well as the plurality of culture, civilization, and language that make up AOF. He suggests that both of their programs are based on an

\footnotetext{
${ }^{58}$ Fara Sow, “La jeunesse se confie à Dakar-Jeunes" Dakar-Jeunes 5 Mar. 1942: 2.
} 
idealized portrayal of African existence and though based in some truth, impossible in the current climate. Though Kalande clearly supports both Senghor's and Socé's efforts to focus on the historical and symbolic importance of great African civilizations, he concludes saying;

Le problème a été posé en termes trop généraux alors qu'il affecte ces terrible cas particuliers qui sont les états de corps et d'âme de centaines de peuples et de groupes humains: Ces groupes gités dans le plus âpre continent qui soit, avec 60 langues connues et tous les obstacles du sol et du climat, s'appellant l'A.O.F.

Even if an admirable concept, Kalande suggests that cultural métissage à la Socé ignores many challenges facing the African continent at the time. His article is, however, a first testament to the thoughtful and passionate contributions that make up the ensuing debate. The publication's contributors chose not only to discuss the colonial situation frankly, but also to address the difficult realities of climate, geography, language, and culture.

Kalande, rather than direct his argument in favor of Socé or Senghor, chose to enumerate the weaknesses and oversimplifications characteristic of both conceptions. ${ }^{59}$

Ouezzin Coulibably, future president of the governing council of Upper Volta from 1957 to his death in 1958, presented his interpretation in an article entitled "Copier servilement la culture occidentale, c'est nuire à la personnalité de nos races.” At first glance, this title seems almost defamatory to the colonial project and an unlikely choice of title for such a publication, but in an administrative climate that believed strongly in the inferiority of African culture, fostering such ideas were likely not seen as inherently dangerous. Coulibaby's ideas are also not as radical as the title alone suggests. He too writes of the inevitably of cultural métissage as well as the complexity of the realities shaping these contrasting and sometimes shared cultures.

${ }^{59}$ Kalande, “Une mise au point,” Dakar-Jeunes, 12 Feb. 1942: 2. 
He explains:

Tendance assimilatrice et tendance anti-assimilatrice, deux extrêmes entre lesquels il y a toute une gamme de cultures possibles. La genèse de notre évolution étant lé métissage inéluctable il nous suffit d'une culture française solide qui tienne compte de notre milieu. Il s'agit de coloriser le Noir sans en faire un fantôme de Blanc.

D'un côté ou de l'autre, on ne peut partir de zéro. L'apport européen dominera toujours mais il s'imprégnera du meilleur de nos civilisations obscures. Éduquer le Noir selon sa nature, côtoyer de près les idées inséparables de son existence intime, cela doit être dans la formule de culture "franco-africaine" car, son but est bien "d'apporter une civilisation, c'est-à-dire toute une nouvelle façon de vivre à la mesure du temps et du pays.

Coulibaby is one of the more effusive proponents of cultural métissage in the publication with some of his ideas being seemingly more accepting of "l'apport européen [qui] dominera toujours" than even Socé. By proposing exchange with less emphasis placed on Africa's cultural value, through the use of terms such as "civilisations obscures" juxtaposed with the idea of Europe's dominant role, Coulibaby and his ideas were likely of little concern to Vichy authorities. ${ }^{60}$

The March 12 issue of Dakar-Jeunes, however, contains more radical ideas from both Mamadou Dia and Abdoulaye Sadji, who were already well known and active in the press by this time. Published under the rubric "La Vie Spirituelle de 1'A.O.F." and relegated to page 10 instead of page 2 or 3 like the previous and following articles in the series, these texts contain the most direct support for Senghor. Though Sadji presents a more nuanced reflection on linguistic métissage, Dia revisits Senghor's 1937 speech while promoting the need to promote African culture and values above all else. ${ }^{61}$ The unique placement of these articles, pushed to the last pages, could suggest the

\footnotetext{
${ }^{60}$ Ouezzin Coulibaly, "Copier servilement la culture occidentale, c'est nuire à la personnalité de nos races" Dakar-Jeunes, 26 Feb. 1946: 3.

${ }^{61}$ See Chapter 4 for an analysis of Sadji's contribution.
} 
publication's uneasiness with the content. Mamadou Dia opens his article stating "la question de l'évolution culturelle en A.O.F. ne peut laisser indifférent aucun Noir intellectuel." ${ }^{62}$ Though he seemingly states what has proven to be the obvious, this reference only further confirms the passion this question evoked among the newspaper's target audience. In his memoirs, Mémoires d'un militant du tiers monde, Dia gives provocative insight into the general climate of the intellectual community at the time, explicitly implicating Sadji in the scene as well. Though this is the only such citation I have found referencing the war directly, Dia further confirms Dakar-Jeunes' importance:

C'est [...] pendant cette période que j'ai commence à faire de l'économie politique, à écrire dans les journaux. D'abord, dans Paris-Dakar, ensuite, Dakar-Jeunes. Période de formation intellectuelle, de bouillonnement. Période, aussi, où nous avons pratique la négritude vécue, où, avec Sadji, nous étions devenus des anti-Français... mais, à fond! à tel point que, quand Hitler a envahi la France, nous pavoisions... parce que nous étions devenus des aigris. Fara Sow, également, était dans cette ligne. ${ }^{63}$

Though this is the most radical testament to their beliefs at the time, it does communicate how Dakar-Jeunes and Socé were tapping into an undercurrent of early African nationalist thought. Dia's Dakar-Jeunes article espouses Senghor's beliefs, making several references that mirror the ideas outlined in the grammarian's 1937 Chamber of Commerce speech while refuting Socé's desire for 'l'assimilation et modernisme à fond." 64 He explains that "c'est ici que nous partageons toutes les inquiétudes de

\footnotetext{
${ }^{62}$ Mamadou Dia, "Pour ou contre... Une culture africaine" Dakar Jeunes 12 Mar. 1942:10.

${ }^{63}$ Dia Mémoires 35-36.

${ }^{64}$ Again in his memoirs, Dia situates Socé in the nationalist currents of this time, claiming he fully espoused assimilation. Referencing a group including Fara Sow and Abdoulaye Sadji he explains: "Ousmane Socé nous avait "catalogués" comme révolutionnaires. Il pensait différemment, nous l'avions constaté, quand il venait en vacances, au Sénégal. C'est lui qui nous avait baptisés "L’École de SaintLouis." En effet, dès ce moment-là, nous prêchions l'authenticité; nous disions que nous n'avions rien à faire avec la culture occidentale. Nous revendiquions notre authenticité, l'identité nationale, l'identité africaine. Nous passions notre temps à écouter la Kora, les hauts faits de Samory, de Soundiata et nous les commentions avec Sadji. C'est à cette époque-là que Sadji a écrit un petit livre qu'il avait intitulé Ce que dit la musique Africaine. Si l'on dépouillait les journaux Paris-Dakar et Dakar-Jeunes de l'époque - on y
} 
professeur Senghor, qui s'émeut à la pensée de voir la jeunesse de son pays orientée vers des destinées qui ne doivent pas être les siennes." Sharing the philosophy that education must be designed to specifically target an African population, Dia enumerates the need for a tailor-made approach stating that "la culture [européenne] qui, sans être inadmissible n'est pas la formule idéale pour faire épanouir l'âme africaine. C'est en puisant dans nos vieilles traditions, en descendant aux sources profondes de notre histoire encore mal connue que nous nous réaliserons pleinement." The theme of a return to cultural authenticity using the analogy of "roots" harkens directly back to Senghor's proposed program, using imagery reminiscent of his closing Banjo citation in "Le problème culturel en A.O.F." - "plonger jusqu'aux racines de notre race et bâtir sur notre profond fond, ce n'est pas retourner à l'état sauvage: c'est la culture même."65 This is the most explicitly pro-Senghor article published in Dakar-Jeunes. It is important to note that contributors spent little time fervently picking sides, but rather focused on addressing the concepts of métissage and assimilation with professionalism and poise, frequently manipulating and combining concepts to best represent their individual realities.

The editors of Dakar-Jeunes, though clearly open to publishing a wide range of ideas, did not print all submissions. Where was Fily Dabo Sissoko in all of this? He certainly was quick to respond to Socé's criticism in 1939 and he is cited along with Senghor throughout the publication as rejecting assimilation in favor of prioritizing

\footnotetext{
trouverait quelques écrits signés Mamadou Dia qui posaient le problème de l'authenticité Africaine. Nous n'employions pas les mots négritude, authenticité, mais c'était le même combat. Nous nous posions, en quelque sorte, comme les défenseurs de l'authenticité africaine avant la lettre, et nous commencions par réhabiliter des hommes comme Samory, en disant que Samory n'était pas le tyran, l'esclavagiste qu'on nous avait décrit. C'était un patriote, un africain, qui défendait sons pays contre l'envahisseur. Nous avons été les premiers à défendre ces thèses-là. Notre nationalisme, au départ, n'était que culturel et non encore économique et politique ; c'est plus tard, que je percevrai l'antagonisme au plan économique et politique. J'ai écrit dans Dakar-Jeunes, en 1942, un article sur la culture Africaine, où je polémiquais avec Ousmane Socé, qui prônait l'assimilation complète." Dia Mémoires 36.

${ }^{65}$ Senghor, Libérté I 21.
} 
cultural authenticity. Senghor was of course in France, and was released from a German military prison camp in February 1942, just weeks after Dakar-Jeunes' first issue. ${ }^{66}$ It is unclear if he was aware of the publication at the time. In the "Avant-Propos" of a version of Les Noirs et la culture published by an unknown editor in New York in 1950, Sissoko explains that he indeed tried to contribute to the discussion that he had, in part, inspired, but that his submission was rejected by the editors:

En 1942 un journal Dakar-Jeunes comme par hasard ressuscita la querelle engagea à nouveau dans une violente polémique. Nous acceptâmes le défi en ces termes : All right: Notre compatriote O.S. rouvre une controverse qui au début de 1939, nous mit aux prises : lui et moi. Aujourd'hui par un vibrant appel à la « Jeunesse Noire », il nous a invité, dit-on, à « une bataille rangée ».

[...] Dakar-Jeunes refusa notre réponse, sous prétexte qu'elle ait “trop longue quoique intéressante," et qu'au surplus, nous y faisons trop d'allusions à une 'époque révolue,' 'à des hommes d'un autre âge.' [...] "Le journal Dakar-Jeunes nous demanda d'apporter les corrections conformes à ses vues, si nous tenions à la publication de notre réponse à des attaques parues sous sa responsabilité. Notre correspondant, rédacteur au journal, plaça quelques points d'interrogation, en regard de certains passages, comparables à un texte de Renan ou de V. Hugo. Il trouvera ici, dans le texte nouveau que nous publions, s'il lui tombe sous les yeux, d'autres rapprochements, qui sont autant de commentaires, et qu'il pourra vérifier. Notre réponse fut nette et sèche: Il ne sera pas enlevé un iota au texte. Et il le verra le jour. ${ }^{67}$

Unwilling to make any changes, Sissoko shows the resolution to remain faithful to his ideas: a sentiment that he communicated as well in his passionate rebuttal to Socé's critique in 1939. He continues saying that he eliminated all of the content related to the 1939-1942 polemic in the publication in question because time had passed and it was more important to look towards the future and focus on meaningful progress instead of an

\footnotetext{
${ }^{66}$ Vaillant 177.

${ }^{67}$ Fily Dabo Sissoko, Les Noirs et la culture (New York, 1950) 6-7.
} 
old quarrel. ${ }^{68}$ This version of Les Noirs et la culture, like the much shorter excerpt published in the Rapports et compte rendu of the "Congrès international de l'évolution culturelle des peuples coloniaux," is a socio-cultural portrait of Black and African culture and history that explains present day cultural norms through the lens of past. He seeks to legitimize and valorize the cultural differences unjustly used to prove African inferiority arriving at the following conclusions:

a) le "Noir" reste noir de vie et d'évolution.

b) le "Blanc" essaye par tous les moyens appropriés, de faire évoluer le Noir selon sa ligne d'évolution propre noire.

La clé du problème est là, et nulle part ailleurs. Voilà comment nous avons compris la question de "L'Évolution culturelle des peuples coloniaux. ${ }^{, 69}$

\section{Conclusion}

The climate in Vichy AOF favored the promotion of traditional African values and the discussion on culture in Dakar-Jeunes was considered reconcilable with National Revolution beliefs. Fostering such a debate hoped not only to ingratiate African intellectuals to the Vichy cause, but also to further promote traditional lifestyles. Socé's fears expressed in his 1937 article "Le Danger" had become the reality of the Vichy platform whose focus on tradition, instead of education or equal political representation, was meant to secure the social hierarchies necessary to guarantee French rule. By ignoring the burgeoning Negritude and nationalist movements developing in France and AOF, the editors of Dakar-Jeunes have provided scholars today with concrete examples of Vichy's shortcomings in the colonial context.

\footnotetext{
68 'Nous avons éliminé de ce texte toute l'argumentation polémique de 1939-1942. L'époque des polémiques, en effet, sans être entièrement révolue, doit, peu à peu, céder la place à la période des réalisations, positives, murement réfléchies." Sissoko, Les Noirs 9.

${ }^{69}$ Sissoko, Les noirs 55.
} 
Does the debate in Dakar-Jeunes provide Socé with the conclusion he so desired? With the editors putting a stop to the discussion while it was still in force, the answer is certainly no. Unfortunately, there is still more to be said and more points of view to share, as I sought only to paint a portrait of the key themes presented. The history surrounding the publication is an important piece of the puzzle and served to answer many questions regarding the motivation driving this extraordinary publication's existence. What can be deduced from reading the articles published under the auspices of "L'évolution culturelle de 1'A.O.F.," however, was the continued relevance of Socé's topic. In no other publication is cultural métissage so passionately and profoundly discussed. In the span of six short months, Dakar-Jeunes hosted a candid forum on a question dear to the hearts and minds of so many in AOF with writers giving nuanced editorials on Socé and Senghor's differing programs. There is little overt animosity expressed on its pages and even Dia, Socé's most vocal critic in this particular publication, refers to him as "mon ami." The articles are written with respect and admiration of fellow compatriots and there is little to suggest the same kind of backlash towards Socé that was referenced in Paris-Dakar five years prior. The question was, and still is complex, with every contribution outlining a different path for negotiating the divergent forces acting on the lives of colonial subjects. Each article specified unique challenges, providing varied solutions with even the most radical ideas still acknowledging cultural métissage's intrinsic role in the colonial situation. Though it is clear that a concise conclusion to such a complex question was impossible, what can be gleaned is a general, even if hesitant, acceptance of cultural métissage's inevitable role in Africa's evolution as long as it was achieved on African terms. The extended focus on 
the question of assimilation and cultural métissage in AOF before and during the war is one testament to the importance of these years in colonial history, which in many ways mark a symbolic crossroads for the French Empire. Not only had colonial subjects begun actively thinking about their inevitable role in determining the future of their countries, but the frequent and culturally engaged contributions of African intellectuals to the press confirm this period's remarkable dynamism. 


\title{
Chapter 4
}

\section{Culture, Language, and Folklore: Abdoulaye Sadji's Nuanced Approach to Métissage}

\begin{abstract}
Abdoulaye Sadji, the third and final author investigated in this study, can be elusive in current scholarship and is often known simply as the author of Nini:

Mulâtresse du Sénégal and Maïmouna. Though these two novels have deservedly earned a solid place among the classics of the Francophone African literary canon, Sadji's work has a much broader range from cultural commentary to an extensive publication of traditional folklore both in book and periodical form. It is indeed from his contributions to Paris-Dakar and Dakar-Jeunes that his role in the discussion of cultural métissage was first apparent. Though less outspoken on the subject than both Ousmane Socé and Léopold Senghor, his writings further confirm the complexity of the questions and debates captivating African intellectuals in the 1930s and 1940s, with assimilation and métissage being paramount. This chapter will situate Sadji's role in the greater discussion of cultural métissage focusing largely on his publications in Paris-Dakar and Dakar-Jeunes with a particular focus on the role of folklore in the debate as it emerges as a common thread further linking Socé, Senghor, and Sadji together as staunch supporters of Africa's own unique oral literary traditions. The primary school manual that Senghor and Sadji co-wrote entitled La belle histoire de Leuk-le-Lièvre: Cours Élémentaire des écoles d'Afrique Noire (1953) may indeed be the most representative expression of the kind of cultural métissage that all three men would espouse.
\end{abstract}


Sadji grew up in the Senegalese town of Rufisque and like so many of his compatriots spent the first decade of his life as a "talibé."1 His father, Demba Sadj, was a marabout and Sadji attended his father's Koranic school until the age of 11. Recognizing not only his son's keen intellect but his interest in European life, Sadj decided to send young Abdoulaye to the "école des blancs." 2 He knew that his son was not destined to follow in his religious footsteps, and indeed Sadji had immediate success at school, earning his primary school certificate (le Cértificat d'Études Primaires Élémentaires) in a mere three years. After passing the entrance exam, he was admitted to the prestigious École Primaire Supérieure de Saint-Louis, otherwise known as the Lycée Blanchot, which along with the Lycée Faidherbe (also in Saint-Louis) and the Lycée Van Vollenhoven in Dakar were among the most prestigious schools in French West Africa. ${ }^{3}$ It is at Blanchot, for example, where Sadji first met Mamadou Dia and Fara Sow. ${ }^{4}$ After finishing his studies in 1926, he was accepted into the École Normale William Ponty. As for so many fellow Ponty graduates, many of whom also contributed to Dakar-Jeunes (Socé, Dia, Sow, Bernard Dadié, and Ouezzin Coulibaly to name only a few), the three years Sadji spent studying on Gorée island were critical in establishing his future professional, literary, and political trajectory. It was indeed the elite colonial schools that were the incubators for the small, albeit active and increasingly influential, community of intellectuals in French West Africa. From examining the common academic trajectories that culminated at William Ponty, one can better understand the

\footnotetext{
${ }^{1}$ The biographical information on Abdoulaye Sadji is limited to a biography entitled, Abdoulaye Sadji: Biographie, that Sadji's eldest son Amadou Booker Washington Sadji published with Présence Africaine in 1997. His name is a direct testament to the passion that so many of the authors of Sadji's generation shared for the writers of the Harlem Renaissance, whose works inspired early Negritude thought.

${ }^{2}$ His father's surname drops the 'i.'

${ }^{3}$ Amadou Booker Washington Sadji, Abdoulaye Sadji: Biographie 1910-1961: Sa vie et sa pensée à un tournant de l'histoire africaine (Paris: Présence Africaine, 1997) 21.

${ }^{4}$ Both Fara Sow and Mamadou Dia contributed to Dakar-Jeunes.
} 
tangible interconnectedness of the African educated elite as well as its relatively small

size. ${ }^{5}$ I have shown that the pages of Paris-Dakar and Dakar-Jeunes included

contributions from African writers and content varied from social and cultural issues to

folklore and tradition. It was, however, a very small group made up mostly of Ponty

graduates, who where responsible for these writings. In 1937, Socé and Sadji were by far

the most prolific African contributors to Paris-Dakar. It is important to remember that

African journalistic publications were still eclipsed in number by their European

counterparts, but no matter how limited, their content unveils the issues that were

influencing significant dialogue and debate in AOF. A sense of camaraderie, certainly

not devoid of conflict, emerges as well. In the press, African intellectuals wrote about

one another's work, reviewed books and essays, published folklore, and tackled tough

questions about culture. ${ }^{6}$ They dedicated writings to each other and select

correspondence confirms the strong ties that were forged among these men. ${ }^{7}$

\footnotetext{
${ }^{5}$ Tony Chafer notes that only $5 \%$ of the population in AOF had attended a French school before the Second World War and of that $5 \%$ an even smaller percentage emerged to form the African elite, the community of intellectuals many of whom attended Ponty. Tony Chafer, The End of Empire in French West Africa (Oxford: Berg, 2002) 28.

${ }^{6}$ In Paris-Dakar, between March and July of 1937, Ousmane Socé reviewed Sadji’s "Ce que dit la musique noire" (March 13, 1937) and Sadji published a piece on Socé's Mirages de Paris entitled "Mirages de Paris: Préface" (June 12,1937). Mamadou Dia also commented on Socé's novel in an article appearing in Paris-Dakar (July 20,1937) entitled "Fine analyse de la crise de conscience d'une génération."

${ }^{7}$ For example, A. Booker Washington Sadji includes several letters from September 1950 between Senghor and Dr. Aujoulat, "le Secrétaire d'État à la France d'Outre-Mer," chronicling the difficulty Sadji had returning to teaching after his first and only significant stay in France. Between August 1948 and October 1949, Sadji travelled to L'École Normale Supérieure de Saint-Cloud in order to pass the exam to become a Primary School Inspector (le Certificat d'Aptitude à l'Inspection des Écoles Primaires). After a year of preparation in France for the exam, Sadji returned to Senegal where he learned that he did not pass. In addition to experiencing his first real academic failure, Sadji was not given a job in education upon his return, likely for political reasons as he was suspected of having anti-French tendencies (he had been reprimanded before). The correspondence shows Senghor, already a deputy at the time, voicing his admiration and support for his friend in efforts to help secure him a post during this difficult time in Sadji's life. In his second letter to Aujoulat dated September 22, 1950, Senghor wrote, "Encore une fois, il s'agit vraiment d'un garçon d'élite, qui est actuellement victime de toutes sortes de persécutions (on ne lui pardonne pas d'avoir préparé le concours de l'Inspection Primaire) et qui mérite d'être aidé. Tu me permettras d'insister, c'est une question qui, pour moi, est de la plus grande importance." In March 1951, Sadji took a post in radio instead (A. Booker Washington Sadji 120 - 134).
} 
Sadji concluded his studies at Ponty in 1929 and immediately took his first professorial job in Ziguinchor in the Casamance region of Senegal (later Thiès, SaintLouis, Kaolack, Dagana, and Louga). Unlike many of his fellow Ponty graduates who would become well known for their political aspirations, Sadji would work in education for most of his life, teaching in several different posts in his native country with the exception of an eight-year period (1948 -1956) that included a stay in France (19481949) and a stint in radio (1951-1956). ${ }^{8}$ From 1956 to 1961, he returned to his first profession, working as the director of the Missirah-Colobane school in Dakar and finally as Rufisique's Primary School Inspector for the last year of his life. Sadji died prematurely of a stomach ailment on December 25, 1961 at the age of 51.

As a young professor, Sadji moved frequently, and in the first decade and a half of his career he had several female "companions" and 13 children between them. He was not a polygamist but rather a young man who had serious relationships in his various professorial posts. It was only his last partner, Simone Carrère, who he officially married. This ambulatory life, moving from post to post, forging relationships with women from different ethnic and religious origins, granted him a unique view of his native Senegal that is reflected in his work. He familiarized himself with the folklore specific to each region and engaged with all social strata from the métisse community in Saint-Louis to the Serer people in Thiès known for their strong oral tradition. ${ }^{9}$ Unlike

\footnotetext{
8 “Abdoulaye Sadji fut effectivement détaché et commença ses activités à la Radio à partir de mars 1951. D'emblée, il eut le soutien de la direction de créer la "chaîne africaine." Ce fut une véritable révolution! C'est alors qu'il institua la systématisation des émissions en langues "vernaculaires," comme on disait alors, c'est-à-dire en langues nationales africaines, lui-même assurant personnellement certaines en wolof. Il fit aussi inviter régulièrement plusieurs groupes folkloriques à venir se produire, sans oublier de célèbres griots et griottes, des instrumentistes spécialistes de la kora et du khalam, mais également de bons batteurs. Il y eut aussi des émissions sur la vie culturelle générale africaine, entre autres sur l'histoire et les traditions." (A. Booker Washington Sadji 134-136).

${ }^{9}$ A. Booker Washington Sadji 53.
} 
Socé and Senghor, Sadji only spent a year of his life in France, and his writing reflects a deep rooting in his native Senegal. His novels target Senegalese society and the complex effects of the colonial situation on his people, while his lesser-known publications and contributions to the press demonstrate a deep respect for Africa's oral literature. ${ }^{10}$

Sadji's treatment of métissage was more nuanced than that of Socé and Senghor who directly called for the embrace of cultural métissage in their texts, Socé as early as 1935 in Karim and Senghor in the 1950s when his conception of "la Civilisation de l'Universel" began to greatly influence his prose. Without theorizing explicitly, Sadji tackled similar questions, addressing biological, cultural, and linguistic métissage in Senegalese society in his various publications. His vast efforts translating and publishing traditional African folklore into French is also reflective of the kind of métissage that he and Senghor espoused. It was in the 1937 speech "Le problème culturel en A.O.F." where Senghor first preached for the Africanization of colonial schools, not only in terms of content but language. Sadji's translations of folklore and ultimately his contribution to La belle histoire de Leuk-le-Lièvre were an extension of this philosophy, which sought to teach the French language using uniquely African content, tailor-made for specifically African needs. ${ }^{11}$

\section{Ce que dit la musique africaine and Paris-Dakar}

1937 has proven to be a pivotal year in AOF. Sadji's role, however, in the same conversations that engrossed Socé and Senghor, has gone unnoticed. His oldest son and

\footnotetext{
${ }^{10}$ A. Booker Washtington Sadji 52.

${ }^{11}$ The Préface reads, “Les auteurs, qui sont Africains et membres de l'Enseignement public, on, pendant de longues années, réfléchi au problème. Il s'agit d'enseigner aux enfants le français, c'est-à-dire une langue riche et nuancée, qui tend à l'abstraction. Il s'agit, en même temps, d'adapter cet enseignement au milieu africain et à la psychologie profonde de l'enfant noir. C'est à ce double souci que répond notre nouvelle méthode." Léopold Sédar Senghor and Abdoulaye Sadji, La belle histore de Leuk-le-Lièvre: Cours Élémentaire des écoles d'Afrique Noire (Vanves: EDICEF, 1953) 4.
} 
eventual biographer, who he simply called Booker, cites several "articles de presse" in his father's biography, though his selection only spans from 1946 to 1958 . The earliest newspaper article that I found, "Une âme qui vibrait dans un corps frêle," was published in Paris-Dakar on March 6, 1937. It was a moving tribute to Dongo Amadou, "un des rares bacheliers du Sénégal," for whom Sadji clearly had great respect and whose premature death he was mourning. In 1937 alone, Sadji contributed to at least thirteen issues of Paris-Dakar, with content ranging from social and literary commentary to folklore: proof of his prolific contribution to the West African press at the time. ${ }^{12}$ Of these thirteen publications, nine were translations of folklore that along with 1936's Ce que dit la musique africaine confirm Sadji's strong focus on the translation and promotion of Africa's oral literature in the early years of his professional and literary career. Mamadou Dia explains that this preoccupation was shared by several others and linked to early nationalist leanings that he likens to "practiced Negritude" since the term and philosophy had not yet been propagated in AOF (and was only just emerging in France). ${ }^{13}$ Dia, Sadji, and Fara Sow, all three teachers, were assigned to Saint-Louis during a two-year period in 1934 and 1935. These years were critical in Sadji's literary trajectory, not only for literary production but also for establishing his cultural and

\footnotetext{
${ }^{12}$ Confirmed publications in Paris-Dakar from 1937 include: "Une ame qui vibrait dans un corps frêle" Paris-Dakar 6 Mar. 1937: 2 ; "Le conte indigène de la moralité des indigenes" Paris-Dakar 17 Apr. 1937: 2 ; "Ce que disent les mélopées sénégalaises: La Chanson des Mariées" Paris-Dakar 11 May 1937: 2 ; "Ce que disent les mélopées sénégalaises: suite" Paris-Dakar 24 May 1937: 2 ; "Ce que disent les mélopées sénégalaises: suite" 1 Jun. 1937: 2 ; "Notre conte: Chien et Singe" Paris-Dakar 8 Jun. 1937: 2 ; "Mirages de Paris: Préface" Paris-Dakar 12 Jun. 1937: 5 ; "Ce que disent les mélopées sénégalaises: La Chanson des Orphelins" Paris-Dakar 15 Jun. 1937: 2 ; “Ce que disent les mélopées sénégalaises” Paris-Dakar 29 Jun. 1937: 2 ; "Gallo M'Baye griot de Rufisque" 27 Jul. 1937: 2 ; "Les lunes d'Afrique" Paris-Dakar 3 Aug. 1937: 2 ; "Utopie et Réalité" Paris-Dakar 6 Oct. 1937: 2 ; "Le surhomme de Nietzsche" Paris-Dakar 13 Oct. 1937: 2

${ }^{13}$ Mamadou Dia, Mémoires d'un militant du tiers-monde (Paris: Publisud, 1985) 37.
} 
political views. In addition to Ce que dit la musique africaine, ${ }^{14}$ Sadji likely penned a

draft of Nini: Mulâtresse du Sénégal during his time in the coastal town, though it is unclear exactly when since the first version was not published until 1947 when it appeared in installments in the first four issues of the journal Présence Africaine. The most widely read version, and the one available today, was published in 1954 by the journal's publishing house. $^{15}$

It seems that the camaraderie and sharing of ideas among peers in Saint-Louis may have helped materialize Sadji's literary ambitions. The trio, who Ousmane Socé referred to as "L'École de Saint-Louis," eventually became known for their progressive views. In his memoirs, Dia criticizes Socé for his full endorsement of assimilation claiming that he and Sadji's group offered an alternative that preached African authenticity. ${ }^{16}$ He explains:

Ousmane Socé nous avait "catalogués" comme révolutionnaires. Il pensait différemment, nous l'avions constaté, quand il venait en vacances, au Sénégal. C'est lui qui nous avait baptisés "L'École de Saint-Louis." En effet, dès ce moment-là, nous prêchions l'authenticité; nous disions que nous n'avions rien à faire avec la culture occidentale. Nous revendiquions notre authenticité, l'identité nationale, l'identité africaine. Nous passions notre temps à écouter la Kora, les hauts faits de Samory, de Soundiata et nous les commentions avec Sadji. C'est à cette époque-là que Sadji a écrit un petit livre qu'il avait intitulé Ce que dit la musique africaine. Si l'on dépouillait les journaux Paris-Dakar et Dakar-Jeunes de l'époque - on y trouverait quelques écrits signés Mamadou Dia qui posaient le problème de l'authenticité Africaine. Nous n'employions pas les mots négritude, authenticité, mais c'était le même combat. Nous nous posions, en quelque

\footnotetext{
${ }^{14}$ Though first entitled Ce que dit la musique noire, the text was entitled Ce que dit la musique africaine in following editions. In this chapter, I will be using, Ce que dit la musique africaine, the current and most well known title.

${ }^{15}$ Dorothy Blair claims the novel was written as early as 1935 though a note in Présence Africaine's fourth issue claims that it had been written roughly 15 years prior, "il y a une quinzaine d'années." Dia in Memoires d'un militant du tiers-monde suggests that he indeed started writing Nini during his time in Saint-Louis. Dorothy Blair, African Literature in French (Cambridge : Cambridge UP, 1976) 189, 38. Dia, Mémoires 36.

${ }^{16}$ See Chapter 1.
} 
sorte, comme les défenseurs de l'authenticité africaine avant la lettre, et nous commencions par réhabiliter des hommes comme Samory, en disant que Samory n'était pas le tyran, l'esclavagiste qu'on nous avait décrit. C'était un patriote, un africain, qui défendait sons pays contre l'envahisseur. Nous avons été les premiers à défendre ces thèses-là. Notre nationalisme, au départ, n'était que culturel et non encore économique et politique ; c'est plus tard, que je percevrai l'antagonisme au plan économique et politique. J'ai écrit dans Dakar-Jeunes, en 1942, un article sur la culture Africaine, où je polémiquais avec Ousmane Socé, qui prônait l'assimilation complète. ${ }^{17}$

Dia's account provides important insight into the intellectual climate at the time and provides context for Sadji's early interest in folklore and Ce que dit la musique africaine's focus on human protaganists, such as Samory and Soundiata. Like so many others, Dia fails to see the nuance in Socé's views and it is important to note that Socé and Sadji were friends by all accounts. ${ }^{18}$ Sadji would refer to him as such in his review of Mirages de Paris published in Paris-Dakar in June of 1937 and later dedicated Tounka, an African legend written as a novella and published posthumously, to him writing, "mon ami Ousmane Socé cette rapide vision de notre cher Cap-Vert." Dia does not, however, underscore the deep admiration he has for Sadji, who he claims was the leader of the Saint-Louis trio, and already an accomplished intellectual and prolific writer by $1935 .^{19}$

\footnotetext{
${ }^{17}$ Dia, Mémoires 36.

${ }^{18}$ See Abdoulaye Sadji, "Mirages de Paris: Préface" Paris-Dakar 12 Jun. 1937: 5, "Utopie et Réalité" Paris-Dakar 6 Oct. 1937: 2 and Tounka which is dedicated to Ousmane Socé.

19 'Pendant toute cette période Saint-Louisienne, c'était autour de Sadji, Fara Sow et moi, formant un trio, que tournait l'équipe. Nous étions les principaux inspirateurs et animateurs de cette équipe de jeunes intellectuels dont la plupart étaient des instituteurs. Sadji était l'un des plus actifs, notamment sur le plan de la production littéraire écrite. C'était un garçon brillant qui avait des dons remarquables d'écrivain; c'est lui qui écrivait le plus; je venais en second lieu. Sadji écrivait beaucoup; il avait même commencé déjà à écrire un roman de protestation contre la Société des mulâtres de Saint-Louis, ce fameux roman qui a tant tardé à trouver un éditeur: Nini: la mulâtresse de Saint-Louis. C'était une critique très sévère. Il avait écrit, aussi, je l'ai déjà indiqué - un texte très intéressant, qui situait parfaitement notre état d'esprit à l'époque: Ce que dit la musique africaine. D'autres textes, de lui, ont été publiés par la suite dont des nouvelles particulièrement savoureuses, et qui montraient l'imagination très féconde de leur auteur. Il avait des dons, c'est certain." Dia, Mémoires 38.
} 
The absence of information about Sadji's earliest literary production, which easily rivals any of the more studied francophone writers working in Paris at time, highlights how little is known about the small literary boom that was taking place in the thirties in AOF and the emergence of an active intellectual community that would begin to challenge the colonial status quo. Since most of the writing appeared in journalistic form, it has not always withstood the test of time and the result is that authors are only known today for the relatively few texts that have managed to stay in print. For Sadji, these have been his novels though Présence Africaine also printed Ce que dit la musique africaine and Tounka, though they were not as widely distributed.

According to Socé, who published a review of the text in Paris-Dakar on March 27, 1937, Ce que dit la musique africaine was first published in the April 1936 issue of Le bulletin d'enseignement and is therefore the earliest publication I have been able to link to Sadji. Socé summarizes his compatriot's work writing, "Sadji Abdoulaye fait une étude historique originale en le sens qu'il se sert de la musique comme document. La vérité historique est le substratum de la légende et les artifices de celle-ci montrent l'âme africaine et son goût du merveilleux." 20 The text's expressed goal was to use folklore to communicate the unique elements that characterize the "African soul" a task that others, namely Senghor, would set out to do in the name of Negritude in the years to come. In the text's "Avant-Propos," Sadji seeks to explain how these legends reflect "une connaissance profonde de l'âme nègre." He writes:

Pour connaître cette âme, il est indispensable de s'attacher à ce qu'on croit être un effet de caprice, d'imagination ou de dispositions passagères: mythes, légendes et surtout mélopées. [...] Cette disposition de notre âme, vous la retrouverez partout, mais surtout dans les récits du genre de ceux qui suivent, dans les mélopées que chantent les femmes noires, les

\footnotetext{
${ }^{20}$ Ousmane Socé “Ce que dit la musique noire” Paris-Dakar 2.
} 
aveugles et dans certains versets religieux déformés et adaptés suivant la conception que se fait le Noir du monde et de la vie. ${ }^{21}$

Sadji's publications in Paris-Dakar in 1937 are consistent with both Mamadou Dia's observations and the expressed goals of Ce que dit la musique africaine. Translations and commentary on folklore dominated his published writings in 1936 and 1937 and his work is therefore one of the earliest manifestations of the use of the genre to communicate the continent's cultural and literary relevance, even before Negritude's official advent. Sadji felt that African authenticity was best expressed through its oral history and the incantatory music that accompanied its melodic recitation. His writings reflect a desire to promote the marriage of music and storytelling that defines African oral tradition and his texts convey the kind of nostalgia that so clearly marked Senghor's first collections of poetry, Chants d'ombre and Hosties noires. Sadji was not, of course, experiencing the same physical exile that inspired Senghor's literary longings for home, but he was still a product of the colonial system and forced to reconcile his French education with his unique culture and upbringing.

Ce que dit la musique africaine is a collection of tales that, unlike Birago Diop's Les contes d'Amadou Koumba or even Sadji and Senghor's eventual La belle histoire de Leuk-le-Lièvre, forgoes the inclusion of the classic animal heroes of West African folklore in favor of human ones. ${ }^{22}$ The nine tales focus on real figures of the past: great men and warriors like Samory and Soundiata, as well as Bikissa, "la reine noire." ${ }^{23}$ In the "Avant-Propos," Sadji introduces Bakary Diabaté, the diali who recites the stories

\footnotetext{
${ }^{21}$ Abdoulaye Sadji Ce que dit la musique africaine (Paris: Présence Africaine,1985) 9-10.

${ }^{22}$ Birago Diop, Les contes d'Amadou Koumba (Paris: Fasquelle, 1947).

${ }^{23}$ Ce que dit la musique afrcaine includes nine tales in the following order: "Soundiata," "AmadouMacina," "Bikissa," "Kélé-Phaba," "Samory," "Samba, ou Kongo-Moussa Galadiégui," "Kombo-Sylla," "Fodé-Kaba," and "Konia-Mary."
} 
included in the collection. Like all African storytellers and griots, Diabaté has been trained to transmit oral history to the current generation with musical accompaniment. A first person narrator, seemingly Sadji himself, sporadically interjects throughout the text, explaining the importance of the tales and the nature of music that introduces and accompanies their recitation. Sadji wants the readers to know that even if the stories have been deeply embellished and infused with fantastical elements as they have been passed down from generation to generation, Soundiata, Samory, Bikissa, and the others included were real people and the story of their lives have, therefore, an even greater significance. Soundiata (Soundiata Keita) was the founder of the Malian Empire, "le souverain puissant entre nous" and first emperor of the Manding while Samory was a great warrior and leader who resisted French rule in the $19^{\text {th }}$ century. Sadji explains:

On a tort de classer parmi les contes africains l'histoire de Soundiata, de Samba-Galadiégui et tant d'autres. Ces personnages ont réellement existé, et si leur histoire est à l'heure actuelle fortement teintée de légende, on le doit à la tradition orale qui, en transmettant l'histoire d'une génération à l'autre, contribue à l'embellir en y ajoutant le merveilleux. ${ }^{24}$

Sadji then argues that their message is diminished when reduced to pure fantasy, because there is truth embedded in the myth. It is likewise this fusing of truth and myth, a kind of métissage in its own right, where the essence of the African soul resides. These stories are so vitally important because they communicate not only African history, but also Africans' unique way of transmitting information documenting the past that was not reliant on the page or the plume. As Dia explained, rehabilitating and translating the stories of these great men and women, was an act of exerting the value of African cultural authenticity on a Francophone reading audience. Was this an act of defiance? Dia suggests that there were revolutionary qualities to Sadji's writing at the time, and his

\footnotetext{
${ }^{24}$ Sadji, Ce que dit la musique 9.
} 
expressed purpose suggests that he was promoting the kind of valorization of culture that would come to define Negritude in the coming years. ${ }^{25}$ He was taking the skills he learned excelling in the colonial education system and using them to communicate something that expressed his own truth, a uniquely African reality shared by his people that was categorically misunderstood and undervalued by the French.

It is no surprise that these translations and transcriptions communicate a deep nostalgia. He introduces Samory's story with an explanation of the method used by dialis when recounting the past. He explains how the diali picked up his instrument, his kora, and played a tune composed in Samory's honor:

Musique étrange, pleine de nostalgie du passé. La musique africaine a ceci de particulier qu'elle ne sert pas d'introduction à la narration des faits; elle ne la suit pas non plus, elle l'accompagne, l'enveloppe et en marque les divers épisodes. Et l'imagination et la sensibilité, exaltée par cette musique, croient voir ou sentir une unité, là où il n'y a que des moments de la vie d'un héros. Mais une chose est certaine, c'est qu'en écoutant les coras, on a l'impression que le passé vit et se meut. ${ }^{26}$

Through his incorporation of commentary describing not only the music, but the techniques and tradition of transmitting oral history, Sadji sought to give his readers as authentic an experience as possible. This act of translation conveys both the importance that he placed on the stories themselves but also on the potential role the French language could have in the diffusion of their message, especially in print. With the absence of written literature being a primary argument used to prove Africa's overall inferiority, the translation and publication of these texts served to promote and confirm the value of oral history and literature to a larger audience.

\footnotetext{
${ }^{25}$ Dia, Mémoires 36.

${ }^{26}$ Sadji, Ce que dit la musique 75.
} 
In addition, having already taught in colonial schools for several years before the publication of Ce que dit la musique africaine, Sadji understood the need to tailor education to the specific needs of African students and the collection's first appearance in a publication dedicated to teaching, Le bulletin d'enseignement, further suggests this link. Later published as a part of Présence Africaine's "Collection Jeunesse," the 1983 edition claims that the text targets young readers from age eleven on, "cette collection s'adresse aux jeunes à partir de 11 ans. ${ }^{.27}$ The original was likely written with school children in mind and is therefore the obvious precursor to the Leuk-le-Lièvre textbook published nearly two decades later with Senghor. ${ }^{28}$ Likewise, if characterizing Sadji in terms of cultural métissage, his unique priority was likely the use of the French language to convey African truths, values, and traditions. ${ }^{29}$ Sadji's work is progressive but his philosophical stance was not explicitly stated in the same way Senghor's and Socé's were at the time. He does, however, communicate clear priorities as seen in his choice of subject matter and genre. For Sadji, the marriage of the French language with African culture was not only necessary for the social and economic development of AOF, but for the promotion of Africa's unique history and cultural heritage. As an educator, one of his primary classroom tasks was French language instruction and Sadji, like Senghor at the time, saw the need for a hybrid approach.

Paris-Dakar was the outlet most used by Sadji at the time and his publications in AOF's main daily paper continue to promote the message of Ce que dit la musique

\footnotetext{
${ }^{27}$ Abdoulaye Sadji Ce que dit la musique africaine (Paris: Présence Africaine,1985) 4.

${ }^{28}$ I have not seen the original text and cannot therefore fully confirm his intended audience. However, his profession, its original publication in Le bulletin d'enseignement, and his later writings suggest that the text would have been written with students in mind.

${ }^{29}$ See the March 12, 1942 issue of Dakar-Jeunes. I will analyze Sadji's contribution, "Un point de vue," later in this chapter.
} 
africaine. His article "Le conte indigène de la moralité des enfants" published on April 17, 1937 explicitly communicates the nostalgia more subtly woven into his 1936 collection. Sadji's writings combined storytelling with descriptions of daily life so that readers could more vividly imagine the scene that was a part of the cultural fabric of so many West African communities. In the first paragraph of the short article, Sadji expresses the love and respect he has for African oral traditions explaining that "le petit conte improvisé au clair de la lune, quand les chaleurs de la saison inoculent l'insomnie aux cerveaux des petits noirs, est un délassement pour l'esprit, une manière d'histoire ancienne que nous aimons revivre en imagination." Sadji focused not only on translating the stories themselves but describing the listening experience. He painted clear portraits of the roles of griots, dialis, and women in these traditions so that readers could better imagine the words in their pure and original form: spoken, chanted, or sung, having never been confined to a page.

In the serial publication, "Ce que disent les mélopées sénégalaises” that ran in Paris-Dakar in May and June of 1937, Sadji focused more specifically on women's role in the transmission of oral history. He describes the accompanying music and incudes the chanted refrains characteristic of the style (a kind of monotonous repeated chant), choosing to write the refrains in Wolof instead of French. Each installment has a different focus, showing how the stories, the chants, and the overall experience varied according to the occasion. He describes marriages, "la lutte" or traditional West African wrestling, and funerals in a piece describing the orphans' song or "la chanson des orphelins." That year, Sadji published only one tale in Paris-Dakar with animal 
protagonists, "Chien et Singe" on June 8, as his writings continued to focus more on the human element.

Even if folklore seemed to dominate his 1936 and 1937 publications, he also published literature reviews and contributed to the rash of commentary that followed Ousmane Socé's Chamber of Commerce Speech, "Impressions d'Europe.” The collection of articles and publications from these early years paint the portrait of an individual fully engaged in French West African intellectual life and, along with Socé, a leader in the group. Again in Paris-Dakar, he and Mamadou Dia published reviews of Socé's Mirages de Paris, which had just been published that year. Both men acknowledged that Socé's work was an accurate reflection of their own personal situation as highly educated Africans forced to reconcile the opposing cultural influences in their lives. Sadji’s June 11 article entitled, “Mirages de Paris: Préface,” provides further context for his literary goals and his focus on tradition, culture, and the translation of folklore into French. For the first time, he communicated the cultural malaise that was likely motivating his choice of genre. In Mirages de Paris, Socé's protagonist Fara's experience was not unlike their own and more relatable to Dia and Sadji than the moderately educated Karim could ever be. ${ }^{30}$ Fara was a character who had the same education as them and who was able to fulfill the dream of going to France, only to find extreme disillusion and eventually death. Sadji, of course, tried to study in France but Socé earned the one highly coveted spot.

The article suggests that Sadji related more to the character of Sidia, the intellectual who wanted to return to Senegal with all the knowledge he had acquired in Paris, marry an African woman, and focus on initiatives to advance the Black race.

\footnotetext{
${ }^{30}$ See Chapter 1 for analysis of Socé's novels Karim: roman sénégalais and Mirages de Paris.
} 
Commenting on Sidia's choices, Sadji wrote, "n'était-ce pas une conception de choses vraiment inouïes pour un étudiant de Gorée chez qui ‘civilisation' voulait dire 'rupture totale avec le milieu." This comment on cultural rupture suggests that Sadji was confronting similar feelings with writings focusing on those aspects of African culture that the colonial education system sought to replace with Western literature and philosophy. He poetically describes the way this rupture develops:

C'est là qu'avec le temps et les loisirs inemployés, s'élaborait chez les sujets prématurément rêveurs le drame de grandes incompréhensions statique incomprise des mœurs et coutumes, des traditions laissées dans la famille, dans le village, et qui ne devaient jamais s'harmoniser avec la vie décrite par les romanciers et les poètes : dynamisme également incompris de la vie civilisée, si nouvelle avec son code de tolérances et de recherche effrénée du bonheur.

The life left behind in the village, the 'mélopées' chanted by women at night, the enchanting music of the kora, the tales of great emperors and warriors of the past seemed incompatible with the French colonial curriculum. Sadji explains that the questions posed in Mirages de Paris are the same ones raised by his peers, confirming the relevance of debates on assimilation and métissage at the time. Like Socé and Senghor, Sadji was commenting on the same cultural issue and grappling to find a path for the future. He concludes his piece explaining that "Mirages de Paris est donc la réponse faite dans une forme admirable, à des questions posées tacitement par toute une jeunesse, la jeunesse noire des écoles, avide de sensations neuves, embarrassée de savoir la voie à suivre." 31

In this conclusion, Sadji perfectly describes the primary question driving Socé's and Senghor's Chamber of Commerce speeches, the debate on assimilation led by Senghor at the "Congrès international de l'évolution des peuples coloniaux" in Paris in

${ }^{31}$ Abdoulaye Sadji, "Mirages de Paris: Préface," Paris-Dakar 12 Jun. 1937: 5. See Appendix for full text. 
September, and the future debate in Dakar-Jeunes. ${ }^{32}$ What path should they take? This was the same query that fueled most articles on culture published by Africans at the time, a question that clearly motivated Sadji as well. I have shown how two camps formed, those who favored the kind of selective assimilation or cultural métissage that Socé preached and those who rejected assimilation in favor of African cultural valorization as articulated publically by Senghor and Fily Dabo Sissoko. It is important to note that many of Sadji's writings pre-date Senghor's famous Chamber of Commerce speech, a speech whose message presented an alternative to assimilation. It would seem therefore, that Sadji, even before Senghor, was presenting a similar program for African cultural evolution that focused on authenticity before assimilation. Since he did not write explicitly about this philosophical stance, he did not become a spokesperson in the same way Senghor and Socé did. His writing in 1936 and 1937 demonstrates his desire to preserve and promote African culture, a progressive view that may have been eclipsed by his more explicitly philosophical compatriots.

Abdoulaye Sadji did not seem to crave the spotlight, and not choosing a side may have been a conscious choice. Even if Senghor came to symbolize resistance to cultural métissage in 1937, he never wavered on the importance of the role of the French language in AOF. He called, however, for a curriculum that was African first, allowing for the use of African languages in primary school education before switching to instruction in French. In reality, most members of the educated African elite were proponents of some degree of cultural métissage, some simply more than others. Sadji, like Senghor was on the African end of the spectrum, whereas Socé was open to

\footnotetext{
${ }^{32}$ For details on the response to Socé's speech, see Chapter 3 and for more on Senghor's role in the debate on assimilation at the "Congrès international de l'évolution des peuples coloniaux," see Chapter 2.
} 
accepting a wider range of French contributions. Sadji, however, never voiced direct support or criticism of either side and can therefore be difficult to place. His writings suggest a strong sense of mutual support and collegiality and I have never found proof of him overtly criticizing any of his peers. He had a great respect for Socé and several publications suggest a real friendship between the two. His thoughtful review of Mirages de Paris reveals that Socé consulted with Sadji on the title of his novel and his response to the Chamber of Commerce speech was by no means anti-Socé. ${ }^{33}$ In his article "Utopie et Réalité," he acknowledges that there had been some backlash after the speech and then continues by giving a thoughtful analysis of one Socé's main arguments: the lack of education available to African women. ${ }^{34}$ In sum, Sadji did not search to polemicize or overtly philosophize; his message of African cultural valorization must be gleaned from his writings themselves. Amadou Booker Washington Sadji cites a tribute to Sadji that Senghor published in the daily paper Le Soleil to commemorate the $20^{\text {th }}$ anniversary of his death that speaks to the authors' more subtle approach:

Je suis heureux de m'associer à l'hommage que l'université et l'Association des Écrivains du Sénégal rendent à l'écrivain Abdoulaye Sadji, à l'occasion du $20^{\mathrm{e}}$ anniversaire de sa mort.

En effet, Abdoulaye Sadji appartient, comme Birago Diop, au groupe des jeunes gens qui, dans les années 1930, lança le mouvement de la Négritude.

\footnotetext{
33 “'Ousmane Socé n'a choisi le titre de son second livre qu'au dernier moment. Il m'avait toujours parlé de 'Panamite' (mal de Panam, mal de Paris, le mot 'mal' étant ici synonyme de nostalgie, de regret, de désir languissant). Pourquoi ce revirement ? Il faut croire qu'un cataclysme sentimental s'est produit en l'auteur. Il a cessé de voir dans les aspects et dans la vie de Panam, cet attrait prenant que l'on est obligé de préférer aux beautés du pays natal." Sadji, "Mirages" 5.

34 “Une question qui n'a rien de nouveau et en soi parait enflammer la jeunesse intellectuelle sénégalaise depuis que notre ami et compatriote Ousmane Socé a, dans une conférence très apprécié, mis en relief l'une des entraves à notre évolution: le manque total de culture et d'éducation de la femme indigène. Cette question concerne l'attitude à prendre d'une part vis à vis de la tradition qui impose le mariage comme discipline sociale, et d'autre part vis à vis d'une tendance, qui, tout en abritant un besoin d'harmonie et un orgueil inavoué, semble exiger le choix d'une femme capable de nous aider à pousser la barque du progrès loin, loin.” Abdoulaye Sadji, "Utopie et Réalité" Paris-Dakar 6 Oct. 1937: 2. See Appendix.
} 
Abdoulaye Sadji n'a pas beaucoup théorisé sur la Négritude : il a fait mieux, il a agi par l'écriture. Il fut l'un des premiers jeunes Sénégalais, entre les deux guerres mondiales, à combattre la thèse de l'assimilation et la fausse élite des 'évolués.' Il a, pour cela, multiplié au-delà des discussions, articles et conférences. ${ }^{35}$

His compatriots were well aware of his contributions to the press, his role in shaping the intellectual community in French West Africa, and his promotion of African culture in his texts, as they too were part of the discussion. They read the numerous articles, and many likely discussed these issues with Sadji himself. His writings, readily available today, only tell a part of the story. His publications in 1936 and 1937, however, paint the detailed portrait of a young, dynamic, and progressive intellectual who was at the forefront of early discussions on African cultural evolution.

\section{Dakar-Jeunes}

The 1942 newspaper Dakar-Jeunes is essential for understanding the debate on métissage and assimilation because of the concentration of articles dedicated to the topic, all joined under the auspices of Ousmane Socé's invitation, aptly titled 'L'évolution culturelle de l'AOF" discussed in the previous chapter. In re-launching the debate started in 1937, Socé was again trying to determine if he and his fellow West African intellectuals could come to a consensus regarding the best path for Africa's cultural future, to use Sadji's terms, "la voie à suivre." It has already been determined that Sadji was a leader among the educated elite in Africa, having published more than most at the time. His general philosophical leanings, his focus on African cultural authenticity and linguistic métissage are embedded in his writings, but rarely explicitly stated. Sadji's contribution to Dakar-Jeunes was unique because he was responding to a thematically

\footnotetext{
${ }^{35}$ A. Booker Washington Sadji 60.
} 
specific question, not publishing a general piece on culture. His article "Un point de vue," appeared on March 12, 1942 the same day as Mamadou Dia's "Pour ou contre ... Une culture africaine," a contribution that included the most fervent support of Senghor's views published in Dakar-Jeunes. Dia rephrases the burning question, "quelle orientation convient-il de donner à la jeunesse africaine? Faut-il s'en tenir à la méthode d'assimilation que l'administration a fait sienne ou vaut-il mieux bâtir notre cité universitaire ici avec des reliques des Empires de Soundiata et d'Askia Mohammed." ${ }^{\text {,36 }}$ His article contains eloquent praise of African folklore and music and he elaborates the importance of preserving the rich cultural and historical heritage that defines his people. ${ }^{37}$

Sadji’s work up until this point has been largely dedicated to the same goals expressed by Dia and his article conveys support of these values. Sadji's contribution was especially thoughtful because he chose to better define the problem first: What is culture? What does it mean in different contexts? ${ }^{38}$ He ultimately argues that the kind métissage his friend Socé was preaching (the kind of métissage that Senghor would eventually espouse) was too idealistic:

L’opinion émise sous ce titre par mon compatriote et ami Ousmane Socé ne manque pas d'ingéniosité. Elle est même tentante, et, pour un esprit qui va loin le métissage culturel dont il parle doit s'accomplir; il est même inéluctable dans une certaine mesure. Il faut cependant une vision

\footnotetext{
${ }^{36}$ Dia explains that “c'est ici que nous partageons toutes les inquiétudes de professeur Senghor, qui s'émeut à la pensée de voir la jeunesse de son pays orientée vers des destinées qui ne doivent pas être les siennes." Sharing the philosophy that education must be designed to specifically target an African population, Dia enumerates the need for a tailor-made approach stating that "la culture [européenne] qui, sans être inadmissible n'est pas la formule idéale pour faire épanouir l'âme africaine. C'est en puissant dans nos vieilles traditions, en descendant aux sources profondes de notre histoire encore mal connue que nous nous réaliserons pleinement." Mamadou Dia "Pour ou contre ... Une culture africaine" Dakar-Jeunes 12 Mar. 1942: 10 .

37 "L'essentiel est que notre culture plonge ses racines dans nos plus anciennes traditions et que nous apprenions à être fiers de notre Afrique ingénument sauvage." Dia, "Pour ou contre" 10.

38 "Le mot 'culture' peut souffrir de multiples acceptions. On pourrait le définir pour un milieu précis: l'ensemble des valeurs qu'une race ou un peuple donné jette dans la balance de la civilisation, comme conformes à la mercuriale de celle-ci et appartenant spécifiquement à cette race ou à ce peuple." Abdoulaye Sadji, "Un point de vue” Dakar-Jeunes 12 Mar. 1942 : 10.
} 
d'avenir assez profonde pour réaliser ce phénomène aussi grandiose et utopique que 'l'Universelle Humanité' [...].

On a scientific or technological front, Sadji saw no threat in embracing métissage, considering Africa was undeniably behind in these domains. He was, however, much more hesitant in his endorsement of cultural métissage, prioritizing again the promotion of African cultural authenticity suggested in his earlier writings. ${ }^{39}$ For Sadji, the cultural and linguistic differences facing Africa and Europe were not easily reconcilable, nor was their reconciliation necessarily desirable:

L'âme nègre s'est emplie de nuit et de mystère. Il ne semble pas que la culture européenne doive extraire l'or de cette gangue. Le nègre le plus cultivé ne peut sentir et frémir comme un Européen même illettré devant le même spectacle. Un Européen peut naître à la Colonie, grandir parmi les Négrillons, courir, gambader avec les adolescents nègres, jamais il ne sera apte à goûter comme eux le charme de nos contes et légendes. Jamais il n'aura leur tournure d'esprit. La technique européenne surprend le Nègre mais ne l'étonne pas. Son moindre souci est de réaliser ce dynamisme des machines rampantes ou volantes qui suppriment la distance: de compartimenter son existence par des divisions arbitraires, des calendriers et des montres.

There is an inherent chasm between the two worldviews and the elements that define the Black soul do not easily translate. Likewise, it is more important to promote African culture than risk diluting it in a possibly futile attempt for compromise. Again, Sadji does not provide a clear answer to the question that Socé posed, focusing more on challenging obvious and over-simplified or idealized solutions. Unlike Dia, he does not voice explicit praise or support for Senghor, even if his message seems to place him more in his camp.

\footnotetext{
39 "Si l'on envisage le mot culture sous l'angle particulier des influences qu'une race a reçues dans le domaine intellectuel et technique d'une race différente, il faut bien convenir qu'il ne peut être question là que d'un dressage plus ou moins heureux. Désormais la seule culture à laquelle nous soyons aptes est celle qui doit refléter nos mœurs et coutumes, nos traditions les plus lointaines." Sadji, "Un point de vue" 10.
} 
Considering that the majority of his writing had been of a cultural nature, he was in large part expressing his personal frustration with translating folklore into French: both the inability of the French language to fully communicate African truths and experiences and Europeans' inability to grasp the real nature and nuance of African culture regardless of language. ${ }^{40}$ The only practical solution and compromise that Sadji had found was to frequently incorporate African words and phrases into his otherwise French texts, something that he did in Ce que dit la musique africaine and "Ce que disent les mélopées sénégalaises. ${ }^{41}$ He argues, however, that this still falls short and that the ideal solution would be the creation of a new African language:

Avant d'entreprendre la culture, fabriquons l'instrument approprié. Le rêve serait de créer en s'inspirant des méthodes grammaticales françaises ou mieux en étudiant les lois morphologiques de nos divers dialectes, une langue africaine ordonnée, claire et rationnelle.

Ultimately, the kind of linguistic métissage proposed by Sadji was also highly idealized, a dream to use his words. It communicates, however, the real value Sadji placed on the preservation of cultural and linguistic authenticity, something he felt a full embrace of cultural métissage would weaken. He understood the inevitability of métissage but was wary of touting it as the only solution to Africa's cultural dilemma.

\section{Tounka}

The dedication to Ousmane Socé that graces the first pages of Sadji's novella Tounka, "A mon ami Ousmane Socé cette rapide vision de notre cher Cap-Vert," is not

\footnotetext{
40 "Les langues européennes, le français notamment, doivent être des instruments entre nos mains pour défricher le terrain inculte de notre âme. Encore que ces instruments soient mal adaptés on ne peut les manier que pour les grandes lignes de cette culture. En effet, elles traduisent difficilement notre conception de la vie, de la force, de la pitié: elles satisfont très peu notre faculté d'émerveillement: elles offrent peu de formes aux données subtiles de notre propre pensée." Sadji, "Un point de vue" 10.

41 "Le métissage culturel envisagé au point de vue linguistique imposerait le sacrifice d'une partie importante de nos insticts et de nos reflexes, et modifierait du même coup notre façon vraie de sentir et de penser. A moins d'incorporer dans la langue européene adoptive la moitié au moins de son contenu en idiome du pays." Sadji, "Un point de vue" 10.
} 
only a testament to their friendship, but to Sadji's understanding of his compatriot's philosophical vision. Like with all of his published folklore, Sadji specifies in his brief "Avant-Propos" that "les thèmes de cette nouvelle sont tirés de légendes où git la vérité" in an effort to further exert the real historical relevance of the narrative. Published posthumously in 1965, a note on the last page of the text specifies that it was written and completed in Louga, Senegal in 1946, four years after the debate occurred in DakarJeunes. Tounka may indeed be Sadji's folkloric masterpiece and is an enthralling tale, with surprisingly relevant metaphorical resonance, that describes the origins of the Lébou people. ${ }^{42}$ The legend claims that they emigrated from the interior to the coast to quench an interminable thirst. After describing the exodus that brought them to the sea, the story jumps ahead five generations to tell the tale of N'Galka. A descendant of Tyongane, one of the original men who led his people away from the desert, N'Galka was an impressive physical specimen and the best fisherman. To honor his prowess, "le Roi de Guedje" (the king of the sea) decided to offer up a princess to be his wife with only two exceptions: that he not share his wife's true "other-worldly" identity and that their children not marry "des filles ou fils des hommes."

What ensues is a story of cultural contact and discord that began with the emigration that resulted in the contact of the desert and sea peoples and their respective gods. N'Galka's union with his new wife Goudi has multi-leveled significance. Firstly, her husband and his people find it difficult to understand and accept her very tangible, physical and cultural differences. They find her to be cold and distant and are suspicious of her supernatural powers. Their son Tounka, a product of physical métissage between a man and a creature of the sea, proves early on that he too has the special powers unique

\footnotetext{
${ }^{42}$ Socé's father was of Lébou origin.
} 
to his mother's people, though he is ultimately forced to repress them to be accepted.

When N'Galka is asked by his elders to take a wife from the village, he gladly accepts, tired of his wife's apparent indifference and failure to meet his conjugal needs in the same way a human wife would. Happy with his new wife, he neglects Goudi and renounces her by revealing her oceanic origins. Scorned, she returns to the sea where her people soon seek vengeance for N'Galka's broken promise with floods and destruction. N'Galka ultimately loses his mind and the "Maitre Féticheur" believes a rupture with the past is to blame:

Mes frères, des dieux délaissés, des fétiches oubliés dans le désert chaud qui fut le berceau de nos ancêtres murmurent contre nous. Ils n'ont plus d'abris, ils ont soif et faim et l'Homme a fui toute la contrée. [...] Nous sommes partis sans retour, et eux ces dieux et ces fétiches n'ont pas pu suivre car ils savent que ces bords-ci sont à l'apanage de génies rivaux qui commandent à la mer, aux tempêtes et aux vagues déferlantes sans repos. Cette rivalité entre dieux de la mer et génies du désert est bien à l'origine de la folie de N'Galka Guèye... Oui tiraillées d'un côté et de l'autre par des esprits antagonistes irréconciliables, la plupart d'entre les plus anciennes familles de nos tribus sont exposées à la maladie qui ne guérit pas, à la folie, à la mort. Mais les dieux de l'antique bercail garantissent le salut de tous ceux qui voudront se placer sous leur protection, qui consentiront des sacrifices d'animaux et de boissons à leur choix. Ces sacrifices devront avoir lieu, comme vous le savez, en public et selon le rite ancestral du 'ndeup' (tam-tam fétichiste accompagné de danses et de libation). ${ }^{43}$

The narrator describes the ritual: the dancing, the drums, and the women's chanting or “mélopées." Nevertheless, their efforts were in vain and N'Galka died that same night.

The sea gods were stronger than the gods of the desert this time.

Sadji, however, does not end the story there but dedicates the last scene to Tounka whose role in the tale is otherwise minor. When the men of the village try to carry away N'Galka's prepared body, they are unable to move. It is only Tounka's presence that

${ }^{43}$ Abdoulaye Sadji, Tounka (Paris: Présence Africaine, 1965) 81-83. 
ensures the father's burial: "On le plaça devant la civière. Il marcha et la civière marcha. Les hommes sentirent que la charge était devenue infiniment plus légère." ${ }^{44}$ The image of Tounka, the product of métissage, moving forward is the last image of the tale. He appears in only a few passages of the narrative, therefore making the choice of the title and the last scene even more significant. The passage where the 'féticheur' is describing the importance of honoring the past seems to be directly referencing Sadji's own beliefs on the importance of cultural authenticity, valorization, and his general support of Negritude's project, yet he chose to end his story with a strong image of both cultural and physical métissage. The narration is balanced and neither group (the sea people nor the Lébou) is villainized in the tale. Both sides deserved respect regardless of their vast cultural differences and had legitimate claims to the land (or water) they inhabited.

Sadji was fully aware of Socé's stance on cultural métissage making his choice of dedication suggestive. Socé would have certainly appreciated the integration of cultural commentary into his narrative as this was the style he adopted in his novels. Sadji, unlike Mamadou Dia, seemed to understand his friend's take on cultural métissage and regardless of the exact degree of support, he understood that Socé was not a proponent of full assimilation as Dia expressed in his memoirs.

Tounka is therefore a tale of emigration, cultural encounter, culture clash, and métissage. Sadji laces his traditional tales with references that were relevant to the debates on culture that had been occurring in AOF for at least a decade. Could the opposing cultural forces acting in AOF be reconciled? His description of N'Galka's people "tiraillées d'un côté et de l'autre par des esprits antagonistes irréconciliables" could easily have been taken from one of his Paris-Dakar and Dakar-Jeunes articles.

\footnotetext{
${ }^{44}$ Sadji Tounka 90.
} 
Sadji continued to focus on promoting Africa's unique culture and history and the ease with which he wove social and cultural commentary into his narratives was a testament to his ability to create texts that were both culturally authentic and socially relevant.

\section{La belle histoire de Leuk-le-Lièvre}

Sadji’s dream of a new African language expressed in Dakar-Jeunes would obviously not be realized, and he had to work under the linguistic constraints of the time. His Dakar-Jeunes piece was as much about expressing the challenges he faced as a writer as it was a commentary on cultural métissage. Touka's folkloric metaphor reads as an Africanized interpretation of the colonial culture clash motivating so much of African literary production. The context of Sadji's work communicates the kind cultural valorization that appeared in all of his publications, even embedded in the social commentary and critique that defined his novels Nini: Mulâtresse du Sénégal and Maïmouna. His writing, often enriched with Wolof words and phrases, still reflected a hybrid reality: the product of a world where some cultural and linguistic métissage was unavoidable. Indeed, all three men Socé, Senghor, and Sadji supported the kind métissage that the textbook La belle histoire de Leuk-le-Lièvre: Cours Élémentaire des écoles d'Afrique Noire embodied, where African culture and French language instruction (not French cultural indoctrination) met. Though Socé was often labeled as an assimilationist, his texts were also laced with folklore, Wolof, and praise of his cultural heritage, thus sharing many thematic commonalities with Sadji’s work.

Inspiration for La belle histoire de Leuk-le-Lièvre can be traced back to the 1930s.

Senghor addressed the issue of textbooks adapted for African students as early as his Chamber of Commerce Speech, "Le problème culturel en A.O.F.," and Sadji's Ce que dit 
la musique africaine was likely written with students in mind. ${ }^{45}$ Published in 1953, the "manuel scolaire" designed for elementary level students, embodies a culmination of much of Senghor's and Sadji's work up until this point and is a masterful collaboration of two of AOF's finest. An act of Negritude and métissage at the same time, the two men used their expertise as educators and their dedication to promoting and valorizing African authenticity to create a textbook designed by Africans for Africans. The "Préface" explains:

Les auteurs, qui sont Africains et membres de l'Enseignement public, ont, pendant de longues années, réfléchi au problème. Il s'agit d'enseigner aux enfants le français, c'est à dire une langue riche et nuancée, qui tend à l'abstraction. Il s'agit, en même temps, d'adapter cet enseignement au milieu africain et à la psychologie profonde de l'enfant noir. C'est à ce double souci que répond ce livre. ${ }^{46}$

La belle histoire de Leuk-le-Lièvre was not, however, the first textbook created for an African audience. It was, more importantly, the first one conceived and written by African authors. Georges Hardy, AOF Inspector of Education from 1912 to 1919 and author of Une conquête morale (1917), had long before pushed to move the French colonial curriculum away from the assimilation model and by 1930 André Davesne’s famous Mamadou et Bineta was already in circulation. ${ }^{47}$ Interestingly, during his 19321933 posting in Thiès, Sadji frequented Davesne who was the Primary School Inspector at the time. Booker Washington Sadji claims that it was indeed the author of Mamadou et Bineta who convinced his father to stay in teaching with the argument that "un bon

\footnotetext{
${ }^{45}$ Jean-Réné Bourrel, "Le Lièvre et le Roi: La belle histoire de Leuk-le-lièvre de L.S. Senghor et d'A. Sadji," Notre Librairie 163 (Sept. - Dec. 2006): 46.

46 Senghor and Sadji 4.

${ }^{47}$ Denise Bouche, “Autrefois notre pays s'appelait la Gaule...: Remarques sur l'apaptation de l'enseignement au Sénégal de 1817 à 1960," Cahiers d'études africaines 8.28 (1968): 117.
} 
instituteur n'avait aucun complexe d'infériorité à ressentir vis-à-vis d'un diplômé de l'enseignement supérieur." ${ }^{\not 8}$

Nevertheless, Sadji and Senghor believed that only African authors could truly write a textbook that spoke to and cultivated the "âme nègre" and that AOF needed a text that could achieve a Negritude-inspired curriculum. By 1937, Senghor was already envisioning this kind of project and in "Le problème culturel en A.O.F.," he elaborates on his dream:

Je ne m'entendrai pas longtemps sur les manuels scolaires; je ne m'attarderai pas à démontrer qu'ils doivent répondre à notre principe du bicéphalisme comme à la diversité des milieux. Il serait facile de prouver - des instituteurs de village me l'ont prouvé - que le fameux Mamadou et Bineta fait merveille en brousse. Mais il n'est pas fait pour les élèves de Dakar: il ne leur parle pas de mille choses familières aux citadins. Je rêve d'un manuel pour chaque école et même, songeant au Télémaque, d'un manuel pour chaque élève. J'attends - je ne rêve plus - le Mamadou et Bineta du Citoyen, et ce livre du Cours moyen qui groupera les meilleures pages des écrivains coloniaux, les noirs comme blancs, les unes éclairant et complétant les autres. ${ }^{49}$

Likewise, he was not necessarily against Mamadou et Bineta but aspired for a better model, one that incorporated his philosophical ideals.

The main task of Le belle histoire de Leuk-le-Lièvre was indeed French language instruction and the 84 beautifully illustrated passages are each followed by reading comprehension questions, pronunciation and writing exercises, vocabulary explanations, and even dictations. In the "Préface," the authors describe in detail the method used in the book, providing educators with the ideal pace and structure for each lesson. They explain that the stories were meant to be read in succession in order to maintain the

\footnotetext{
${ }^{48}$ A. Booker Washington Sadji 54.

${ }^{49}$ Léopold Sédar Senghor, Liberté I (Paris: Seuil, 1964) 16.
} 
continuity and natural cohesion of the narrative. ${ }^{50}$ They chose Leuk, because like the fox of European tales and fables, he embodied intelligence and possessed the ingenuity that allowed him to overcome difficult situations. Most of the recurring characters of West African folklore are included in the narration from Gaïnde the lion and Diargogne the spider to Bouki the hyena, Leuk's eternal nemesis.

In his article "Le Lièvre et le Roi: La belle histoire de Leuk-le-Lièvre de L.S. Senghor et d'A.S. Sadji," Jean-René Bourrel claims that the text's structure is similar to the traditional French "roman de formation" or the German "bildungsroman" and that "les deux auteurs fusionnent les traditions du conte africain et du roman européen de formation." 51 Indeed, in the $69^{\text {th }}$ passage, Senghor and Sadji introduce Samba "le nouveauné" who is adopted by Leuk and embarks on the kind of initiation that characterized the heroes' tales in Sadji's Ce que dit la musique africaine. The birth of Samba introduces the human element that is so important in Sadji's folklore. Not only does Samba complement the cast of animal characters of the previous section, he serves to communicate the eternal link between man and nature while being relatable to young readers. The textbook ends with a common trope of African folklore: Samba's "retour triomphal" to his people who ultimately proclaim him king. With Leuk's shrewd guidance, Samba was able to achieve his destined greatness. Was this a metaphor for the African student who too could thrive and grow through the double formation of African culture and French language? The answer would seem to be 'yes' as they develop and promote the metaphor themselves comparing the African student to a "jeune plante noire" that will grow even stronger through the study of French: "C'est par l'apprentissage de la

\footnotetext{
50 "Présenter à l'enfant noir des récits isolés, sans aucun lien qui les rattache les uns aux autres, serait tuer la vie et le movement dont son imagination anime ces récits." Senghor and Sadji 4.

${ }^{51}$ Bourrel 46.
} 
langue française que nous arriverons le plus sûrement à cette transplantation qui donnera vigueur à la jeune plante noire.",52

Sadji and Senghor chose to adapt the tales that most West African children knew, “des récits déjà éntendus par l'enfant dans sa langue maternelle est déjà vécus de lui," in order to promote the bilingualism Senghor called for in his speech. Sadji also claimed that French fell short in communicating the message of these tales yet their ultimate message was never compromised as these the stories were most likely already engrained in the young students' consciousness in their original language. ${ }^{53}$ La belle histoire de Leuk-le-Lièvre was a tour de force of African-driven cultural métissage and a rejection of French imposed assimilation. What they did with Leuk-le-Lièvre was create a curriculum on their own terms that ensured African control of education allowing them to achieve the goals that they had been steadily establishing and propagating since the mid 1930s. They acknowledge, albeit hesitantly, that their method requires some assimilation of French techniques:

Éduquer signifie non seulement cultiver dans le milieu naturel, mais aussi, selon l'étymologie du mot, transplanter. Il est question, sur ce plan, d'amener l'enfant noir à assimiler les éléments fécondants de l'esprit français. Comme dans les récits contemporains en langue indigène, nous intégrons, nous assimilons, prudemment il est vrai, les objets et les techniques de la civilisation européenne. ${ }^{54}$

Selective assimilation was unavoidable in this text that reflected a marriage of African content, French language instruction, and European pedagogical techniques. What they are describing is métissage by definition: the sharing and adapting of culture, method, or knowledge for the betterment of a group or groups. They were sure to announce this with

${ }^{52}$ Senghor and Sadji 5.

${ }^{53}$ Senghor and Sadji 4.

${ }^{54}$ Senghor and Sadji 4. 
caution, "nous assimilons prudemment il est vrai," and likewise were not calling to assimilate all of French culture, but only those elements that fill a void, those that are the most "fécondant." This is similar to the kind métissage Socé was presenting in "Impressions d'Europe" without the mention of the "autocritique" that required a critical view of African culture as well. Sadji and Senghor took the initiative to create an authentically African text in an effort to reclaim control of the curriculum that had been determined by the French for so long. La belle histoire de Leuk-le-Lièvre was first an act of Negritude, creating a text based on "les valeurs culturelles du monde noir." By designing the curriculum and determining the amount of métissage that the text could promote, Sadji and Senghor were rejecting the colonial model, while presenting a constructive, Africanized program for the future. A textbook for primary school students, La belle histoire de Leuk-le-Lièvre sought to provide a well-adapted foundation for those very students who would eventually determine Africa's future. It borrowed European pedagogical techniques, yet it prioritized a strong foundation in African culture and morality. Through this hybrid approach to learning, the text could simultaneously promote the skills that were necessary to succeed in the colonial or even post-colonial world by ensuring both the preservation of Africa's rich cultural heritage and the acquisition of essential practical skills: reading, writing, and critical thinking in French.

\section{Conclusion}

In his tribute to Sadji, Senghor explains that “Abdoulaye Sadji n'a pas beaucoup théorisé sur la Négritude: il a fait mieux, il a agi par l'écriture." This characterizes perfectly the writing investigated in this study so rich in ideas but rarely philosophically explicit. I found no example of Sadji speaking out strongly in favor of or against a 
particular side and his leanings had to be gleaned from his writings. I chose to address only Sadji's little or unknown texts, those that were directly or closely linked to the debates on cultural métissage investigated in the three previous chapters of this study. Sadji, unlike Senghor and Socé, rarely addressed philosophy directly, but his primary focus was the promotion of African cultural authenticity, one could even say Negritude, though I do not have any examples of him using the term. Even if not explicit, his writings are important in the discussion of cultural métissage as he was directly responding to and articulating the same questions as Socé and Senghor: "la voie à suivre," what cultural path to take? He was widely published in AOF as early as 1936 and emerged as one of the primary intellectuals of the time. His focus on the translation of folklore into French communicates his passion for the preservation and promotion of culture but also his understanding of the importance of the French language in Africa's future, a future that would inevitability include some cultural métissage. For Sadji, this métissage had to be African-driven as La belle histoire de Leuk-le-Lievre so effectively communicates.

It is important to note that Nini: Mulâtresse du Sénégal and Maïmouna are also relevant in this discussion as Sadji addresses the often-negative side effects of the colonial situation in both novels. Physical (biological) and cultural métissage are central themes in Nini, a biting critique of Saint-Louis' "métisse" community that Sadji presents through his portrait of Nini, a mixed race woman desperate to marry a French man and committed to ignoring and masking her African origins. Maïmouna is also a novel laced with social commentary and criticism, this time aimed at the community of 'évolués' in Dakar. Both warn of the risk of ignoring African culture and heritage and therefore carry 
on the message of his lesser-known texts. Wanting to show a side of Sadji that has not been articulated and to communicate his more direct role in the discussion at hand, I chose not to include his novels in this study, focusing on the press and folklore. ${ }^{55}$

Sadji's message was much more nuanced than Socé's and Senghor's, but equally important. His early role in the promotion of Negritude ideals and African cultural authenticity in AOF has been overlooked, again eclipsed by Senghor's imposing presence. He was at the forefront of Negritude thought, even without using the term, subtly calling for an Africa that was African first, an Africa shaped for and by Africans that embraced cultural métissage carefully and meticulously so as not to risk diluting that which made the continent unique. His philosophy was always more practical, rarely idealized or utopian like both Socé's and Senghor's tended to be. Sadji's view was an Afrocentric one and I have no proof that would suggest he would be compelled by Senghor's eventual conception of "La Civilisation de 1"'Universel."56 After all, when responding to Socé in Dakar-Jeunes, he did claim that as respectable and tempting as it was that "il faut cependant une vision d'avenir assez profonde pour réaliser ce phénomène aussi grandiose et utopique que 'l'Universelle Humanité.'” As an educator in

\footnotetext{
${ }^{55}$ Nini was first published in the first four issues of the journal Présence Africaine. Sadji was on the 'Comité de rédaction' along with B. Dadié, Cissé Dia, Ayouné, Balandier, Fily Dabo Sissoko, Mamadou Dia, Mercier, Meyé, H. Panassié, T. Serpos, and M. Sillaret. Alioune Diop was the director and Socé joined the redaction committee from the fifth issue. In the forth issue, there was a note apologizing for some oversight in editing and mistakes found in Nini's first three installments that also comments on métissage: Nous nous excusons auprès de nos lecteurs de la présentation matérielle et littéraire du roman de Sadji-écrit il y a une quinzaine d'années - (en particulier pour le numéro trois où tant de coquilles et de fautes se sont glissées à notre vif regret). Nos conditions de vie matérielle à Paris ne nous avaient pas permis de veiller avec une minutie tranquille à l'impression et à la présentation de nos textes. Nous espérons pouvoir dès maintenant offrir à nos lecteurs une revue digne d'eux. Nous profitons de l'occasion pour déclarer, une fois pour toutes, que notre intention en publiant ce roman est tout simplement d'évoquer pour ceux qui ne la connaissent pas, une certaine ambiance de la vie sénégalaise. Les responsables de la vie intellectuelle de la revue sont convaincus que l'avenir est au métissage mental et physiologique des races. L'évolution du monde nous y mène inévitablement. Et c'est tant mieux, car c'est la manière la plus radicale de triompher du racisme blanc au noir. "Nini" Présence Africaine 4 (1948): 647.

${ }^{56}$ Though Senghor began to conceive of this concept in the 1950s, Sadji died before it became his central philosophy.
} 
AOF, he was invested in Africa's future and his work on curriculum development communicated his understanding of the need for thoughtful, African-driven cultural métissage that allowed for the promotion of the French language with culturally relevant materials. By studying his writings in the 1930s and 1940s, one can better understand the very significant role Sadji had in the debates and dialogues shaping intellectual life in AOF from his Ponty graduation until his premature death just one year after Senegal gained its Independence. Known as the author of Nini and Maïmouna, he should be remembered as a pioneer of African folklore, one of the original champions of African cultural authenticity, and a thoughtful, though often hesitant, supporter of cultural métissage. 


\section{Conclusion}

The West African press is the foundation of this dissertation. The content of Paris-Dakar and Dakar-Jeunes alone paints a remarkably vivid picture of intellectual life in French West Africa between 1937 and 1942. Articles reveal the key questions and concerns with métissage emerging as a popular, and hotly debated, response to the colonial situation. Though historians who study this period have most certainly perused the pages of these publications, their ephemeral nature (the delicate paper, the poor and increasingly faded print) makes the study of these documents tedious at best. If you have the rare opportunity to behold the originals, they are so delicate that they crumble if not handled with the utmost finesse, and the microfilms of Paris-Dakar available in the United States, although largely complete, are often nearly impossible to read. Literary publications from colonial subjects were still rare in the 1930s and 1940s, especially in AOF. The press, however, provided a platform for expression and the publications that I have studied reveal, not only the issues shaping discourse from education reform to cultural métissage, but the young intellectuals who have proven to be at the vanguard of change. In 1937, it was Ousmane Socé, Léopold Sédar Senghor, and Abdoulaye Sadji who stood out above the rest.

Throughout the years I have been studying cultural métissage and examining the microfilms and archival materials that inform so much of this study, I have made several conclusions that I was unable to fully understand through other scholarly materials. Firstly, I have been able to grasp the interconnectedness of the West African intellectual community that was composed of elite members of the class of "évolués," often graduates of l'École William Ponty. The limited size of this group is a result of the 
colonial government's strict regulation of the access to higher education that was designed to keep the number of highly educated Africans extremely low. Likewise, the desire to maintain and improve access to higher education was a primary motivating force behind much of the dialogue on culture occurring in AOF in the 1930s.

Secondly, the texts that are readily available today fail to paint a complete portrait of the philosophical views and intellectual activity of many African writers. Ousmane Socé and Abdoulaye Sadji are most often remembered for their novels, and not for the historical and cultural significance of their other writings, from collections of folklore to social, cultural, and literary commentary published in the pages of Paris-Dakar and later Dakar-Jeunes. ${ }^{1}$ They did not have the longevity or renown that has ensured the preservation of the vast corpus of Léopold Sédar Senghor's writing, for example. Though again, investigation into periodical publications in 1936 and 1937 uncovered early writings that predate the first essay he chose to include in Liberté I, "Le problème culturel en A.O.F.," and communicate seemingly overlooked details into Senghor's philosophical leanings at the time. The contributions of African intellectuals to the West African press, men who will eventually be remembered as literary and political leaders, have largely been neglected and scholarship has failed to convey the dynamism of the time as reflected on the pages of Paris-Dakar and Dakar-Jeunes.

The most important conclusion, however, is the central importance of the debate on cultural métissage and assimilation in AOF in the years leading up to and during the Second World War. My research suggests that, for the West African intellectual community, it was the most debated, and likely most important cultural question of the

\footnotetext{
${ }^{1}$ Though these are the documents examined in this study, both Sadji and Socé published in several other periodicals and journals.
} 
time. The introduction to Socé's Dakar-Jeunes contribution confirms, "des problèmes qui préoccupent la jeunesse en A.O.F., l'évolution culturelle est assurément, l'un des plus passionnants." ${ }^{2}$ Senghor's and Socé's Chamber of Commerce speeches, "Impressions d'Europe" and "Le problème culturel en A.O.F." mark the moment when the public discussion on culture in French West Africa became widespread, since transcripts of their messages were distributed across the territory on the pages of Paris-Dakar. They also occurred during a period of heightened liberalism in colonial policy under Marcel de Coppet that included increased freedom of the press. ${ }^{3}$ Though more needs to be done to fully confirm these findings, initial investigation of earlier publications and newspapers such as Le Sénégal and La France Coloniale between 1933 and 1936 did not uncover the kind of cultural material that frequently appeared on the pages of Paris-Dakar between 1937 and 1939, and that dominated Dakar-Jeunes in $1942 .^{4}$

In addition, when the editors of Dakar-Jeunes announced that they would be putting an end to the publication on February 25, 1943, they directed their readers to the newspaper, TAM. TAM was a very different publication, focused almost exclusively on wartime news with the Allied cause replacing the Vichy propaganda that informed the content of Dakar-Jeunes. ${ }^{5}$ The period between Socé's Chamber of Commerce Speech in July 1937 and the end of Dakar-Jeunes appears to be exceptional. It marks a critical period of cultural questioning in French West Africa, especially on the topic of cultural métissage and assimilation. The unique political environments that defined the period,

\footnotetext{
${ }^{2}$ Ousmane Socé, "L'évolution culturelle de l'A.O.F." Dakar-Jeunes 29 Jan. 1942: 2.

3 The Popular Front's arrival was met with enthusiasm in Africa, especially among the educated African elite who were supportive of the reforms this leftist political coalition promised, including freedom of the press, freedom of movement, as well as the right to belong to a trade union. Tony Chafer, The End of Empire in French West Africa: France's Successful Decolonization? (Oxford: Berg, 2002) 33.

${ }^{4}$ This research was conducted at the Institut Fondamental d'Afrique Noire (IFAN) Library in Dakar.

${ }^{5}$ The Center for Research Library in Chicago has a limited collection of TAM available.
} 
first the Popular Front, and later Vichy rule, likely served to foster the kind of open dialogue reflected in journalistic writings, even if for very different reasons.

Though politics played an important role, Ousmane Socé was the central figure giving life to the question of cultural métissage in AOF. He was the first to speak at the Dakar Chamber of Commerce and the source of the debate's several reprisals in the press in the months and years to come. As early as September 1937 when he published "Le Danger" in Paris-Dakar voicing his concerns for Senghor's proposed reforms, it was clear that Socé wanted Africans to seriously consider the best path for Africa's cultural evolution: to assimilate or not to assimilate? For him, cultural métissage was the answer and he seeks to make his case again in 1939 in his response to Fily Dabo Sissoko's contribution to the Rapports et compte rendu of the "Congrès international de l'évolution culturelle des peuples coloniaux" and later in Dakar-Jeunes. Senghor came to represent the opposing camp, the anti-assimilationists, though his role is more symbolic than active. Other than leading discussions on the topic at the "Congrès international de l'évolution culturelle des peuples coloniaux" just weeks after leaving Dakar, Senghor was absent in the post-speech fallout as well as in Dakar-Jeunes. There is no doubt, however, that the Negritude-inspired message of his Chamber of Commerce speech greatly impacted the intellectual community in AOF. His frequent mention and citation in articles addressing the question of culture serves as proof of his influence.

The aforementioned talks sponsored by the Foyer France-Sénégal in 1937 served to escalate and define discussion on métissage and assimilation in AOF. I believe, however, that both Socé's and Senghor's messages were inspired by a previous and ongoing discussion on the role of assimilation in education, linked to the institution of 
l'École rurale populaire in French West Africa in 1934. Senghor's contribution to the Rapports et compte rendu from the "Congrès international de l'évolution culturelle des peuples coloniaux," suggests that the community of 'évolués' was largely opposed to these reforms that customized rural curriculum to better meet the needs of traditional lifestyles and livelihoods. I have explained that the debate on cultural métissage bled frequently bled into reflections on the role of assimilation in AOF, and this appears to be the direct link between the two. Ousmane Socé, therefore, likely inserted the concept of cultural métissage into a pre-existing dialogue on assimilation that had emerged in response to rural school reform. In his article, "La résistance de la bourgeoisie sénégalaise à l'École rurale populaire," Senghor cites, in detail, several articles that address the reforms and their reception:

On a souvent souligné l'accueil favorable que les populations d'A.O.F. ont fait à l'École rurale populaire. On n'a pas assez dit la résistance que lui oppose et lui oppose encore la bourgeoisie des 'évolués,' la bourgeoisie sénégalaise plus que d'autres, qui donne le ton aux autres. Elle est frappante portant la quasi-unanimité du mouvement. Elle trouve son expression la plus nette dans les journaux dirigés ou inspirés par des indigènes: Le Périscope africain, l'A.O.F., Le Progrès, le Jeune Sénégal. Un journal comme le Périscope africain a pu changer de directeur politique, même de politique, sa position devant le problème n'a pas changé. ${ }^{6}$

The polemic surrounding l'École rurale populaire was centered on the urban elite's desire to ensure the assimilation-style education necessary for more advanced careers. They feared that changes targeting the specific needs of rural populations, that reflected an Africanization of the curriculum, would trickle down to urban areas and stifle their access to a competitive education. Colonial subjects were aware of ever-changing

\footnotetext{
${ }^{6}$ Léopold Sédar Senghor, "La résistance de la bourgeoisie sénégalaise à l'école rurale populaire" Le congrès international de l'évolution culurelle des peuples coloniaux: Rapports et compte rendu (Paris: Bibliothèque nationale imprimés, 1938) 40.
} 
colonial reforms, some that resulted in increased liberties, while others took steps back.

In this same text, Senghor acknowledges that the administration's rhetoric justifiably caused concern:

[Le Gouvernement Général] a invoqué la crise, les débouchés des moins et moins nombreux qu'offraient l'Administration et le commerce quand s'accroissait le nombre des diplômes indigènes; il a préconisé le retour à la terre et aux arts indigènes ou résidait l'avenir économique du Pays. Dans ce but, il avait créé l'École rurale populaire. ${ }^{7}$

Referencing an eventual reduction in available positions, the administration justified its shift towards a more practical form of education that would purposefully limit the availability of coveted degrees. This concerned the urban elite who preferred jobs in the administration and who no longer relied on traditional livelihoods. For critics of the reforms, this was perceived as an effort by the colonial government to reduce access to higher education and more lucrative careers. Better understanding the role that rural school reform had in the evolution of cultural métissage is the obvious next step in my research.

I maintain that Socé's and Senghor's Chamber of Commerce speeches are the symbolic origin of the debate on métissage and assimilation presented in the previous chapters, as they established the key questions that would be referenced for the years to come, both presenting alternatives to the colonial-style assimilation model. Senghor's summary of the negative reaction to rural school reform suggests that this was not, however, the first example of a public dialogue on culture occurring in AOF. Socé confirms this in a January 1937 article entitled "Le circle vicieux est rompu..." in which he praises De Coppet for granting two additional scholarships for higher education in

\footnotetext{
${ }^{7}$ Senghor, "La résistance" 43.
} 
France. $^{8}$ The thread linking all of these discussions was education and, more importantly, Africans' desire to pursue higher education: something that many felt was threatened by rural school reform. In Socé's article, he suggests that for many years, young Africans had been seeking increased access to advanced studies with their requests being consistently denied or stalled by the administration. It is important to reiterate that there were no more than ten Africans studying in France at the time and very few were even allowed to sit for the Baccalaureate exam in AOF. ${ }^{9}$ Socé writes:

Ces dernières années, à part ceux qui avaient la faveur d'une bourse d'études métropolitaine, la jeunesse intellectuelle du pays se débattait dans un cercle vicieux.

- Nous voulons élever au-dessus de la condition qui nous est dans l'administration disaient les jeunes qui se sentaient capables de mieux faire.

- Votre instruction est insuffisante leur répondait-on; vous n'avez pas les diplômes exigés pour accéder aux carrières que vous convoitez.

Et cette jeunesse pleine de bonne foi se jetait sur les livres, se ruait à la conquête des diplômes. Parchemin en poche, à défaut de parchemins, se sentant capables d'affronter les Concours ils revenaient frapper aux portes.

- Ah! Pardon leur disait-on: Samba, vous êtes sujet français il faudrait vous faire naturaliser français. Amadou vous êtes déjà fonctionnaire et telle circulaire vous empêche de changer de cadre. Abdoulaye, cet emploi est réservé à une catégorie de personnes bien déterminée.

\footnotetext{
8 “Trois mois après son arrive à Dakar, M. le Gouverneur Général de Coppet a rapporté "la circulaire:" des concours, sous la seule condition de la sélection des vraiment capables vont donner des débouchés à la jeunesse intellectuelle. Je crois savoir que deux bourses d'enseignement supérieur ont été accordées cette année à des indigènes ainsi que le demandait l'un dernier au Conseil Colonial du Sénégal l'Association des étudiants ouest-africains en France que j'avais l'honneur de présider. M. Gouverneur Général de Coppet a rompu le cercle vicieux où se débattait si péniblement la jeunesse intellectuelle. Il l'a fait parce que le gouvernement qu'il représente est hautement humain, et aussi parce qu'il sait que cet état de choses, come les gaz comprimés, pouvait finir par une explosion." Ousmane Socé, "Le cercle vicieux est rompu" ParisDakar 9 Jan. 1937: 1.

9 "L'histoire des lettres sénégalaises retriendra le nom de celui qui [...] nous a décrit la vie des 'Quatres Communes' entre les deux Guerres, mais aussi la vie des premiers étudiants ouest-africains en France, où dans les années 1930, nous n'étions pas plus de 10.” Léopold Sédar Senghor, “Adieu à Ousmane Socé Diop," Bingo May 1974: 20.
} 
Tel était l'angoissant cercle vicieux où se débattait la jeunesse intellectuelle. ${ }^{10}$

It is unclear, however, the nature and scope of the reaction to rural school reform prior to 1937, including what impact it had on the press. It is evident that Socé's and Senghor's Chamber of Commerce speeches greatly influenced public dialogue, resulting in several related publications. Socé and Senghor were likely inspired, however, by existing concerns related to l'École rurale populaire. The debates on assimilation and métissage launched in 1937, motivated Africans to take the issue one step further and focus not only on education, but on the broader topic of cultural evolution. It was Socé and Senghor who publically extended the argument to address social norms and structures, traditional culture, and technological advancement.

Close investigation of the 1930 s reveals that West African colonial subjects were actively thinking about the future at the same time Negritude was being conceived in France. Like their metropolitan counterparts, West African intellectuals wanted to be implicated in decisions regarding their own cultural evolution from the amount of métissage to accept or reject to strategies for preserving cultural authenticity. The debates surrounding l'École rurale populaire and cultural métissage are never truly resolved, but publications in the local press prove the active participation of West African intellectuals in discussions addressing social and cultural issues. Again in his contribution to the Rapports et compte rendu, Senghor makes an important observation when contextualizing criticism of rural school reform: "Le social est lié au politique. Que les 'évolués' demandent des 'diplômes,' ils pensent à leur gagne-pain, ils pensent aussi à prendre une place de plus en plus grande dans l'administration de la Cité. Ce

\footnotetext{
${ }^{10}$ Socé, "Le cercle" 1.
} 
n'est pas à dire qu'on tende au séparatisme ; tout au plus, à l'autonomie."11 I would argue that all of the writings investigated in this dissertation communicate a yearning for autonomy and a desire to influence colonial decision-making. Criticism of l'École rurale populaire, the Chamber of Commerce speeches, and the many contributions to DakarJeunes are all examples of Africans making their voices heard by constructively expressing opinions on issues shaping their daily lives and their future. In "Les Noirs et la culture" from the Rapports et compte rendu, Fily Dabo Sissoko explains, "Le jour où on le voudra, et comme on le voudra, nous fournirons des docteurs, des agrégés et des licenciés dans toutes les branches du savoir." ${ }^{\prime 2}$ I have no proof of Africans rejecting education, though many, like Sissoko, criticized the education that colonialism forced upon them. Simply, yet eloquently through his use of the future tense, Sissoko expresses the same motivation behind Senghor and Sadji's textbook, La belle histoire de Leuk-leLievre - the drive to determine one's own future and to advance on culturally authentic terms. It is therefore fitting that the last text explored in Chapter 4 of this dissertation is La belle histoire de Leuk-le-Lievre, as it is a practical, physical manifestation of the ideas that had been expressed at different times, and in different ways by Socé, Senghor, and Sadji. In their textbook, Senghor and Sadji acted on their desire for educational autonomy by publishing a textbook with an Africanized curriculum that could be used in West African classrooms. They prioritized the preservation of African cultural authenticity first, even if their textbook, designed to teach French, inherently promoted métissage as well.

\footnotetext{
${ }^{11}$ Senghor, "La résistance" 43.

${ }^{12}$ Sissoko "Les Noirs et la culture." Le congrès international de l'évolution culurelle des peuples coloniaux: Rapports et compte rendu (Paris: Bibliothèque nationale imprimés, 1938) 122.
} 
Embarking on this project, I wanted to trace the evolution of the philosophy of cultural métissage and better understand the connection between Socé's and Senghor's Chamber of Commerce speeches and the debate on cultural métissage that occurred in Dakar-Jeunes in 1942. In the process I have come to understand and appreciate the nature of the dynamism occurring in French West Africa, when changes in the colonial administration corresponded to a period of cultural awakening and existential questioning in the African intellectual community. I have sought to provide a more complete portrait of the philosophical outlooks and prolific intellectual activity of Ousmane Socé, Léopold Sédar Senghor, and Abdoulaye Sadji by uncovering and communicating the messages of little-known or unknown texts. For Socé and Sadji especially, there is more to these men than what can be understood from their novels alone, and the full impact that they had in AOF has been undervalued.

Between the two wars, the mentalities of colonial subjects were changing both in France and in Africa, but the undeniable importance of Negritude has overshadowed examples of similar activism occurring concurrently in French West Africa. Since the majority of writings in the 1930s and 1940s were journalistic, relevant texts are difficult to access and many may have not withstood the test of time. Though I still have unanswered questions that require more archival research, I can confirm the importance of two key discussions on education and culture that greatly influenced discourse in the 1930s and the 1940s in AOF. Rural school reform sparked debate on the role of assimilation in colonial education as early as 1934, the year the reform was enacted. In 1937, Socé's and Senghor's Chamber of Commerce speeches responded to this existing 
rhetoric and expanded the topic to African culture as a whole, with a new focus placed on cultural métissage.

The pages of Paris-Dakar and Dakar-Jeunes communicate the presence of a small, but dynamic, intellectual community, who understood that they were on the precipice of a "monde nouveau," to borrow from Socé. Even if the ideas expressed were at times divergent and not always explicitly anti-colonial, the texts I have explored all convey a unifying desire for increased autonomy. Linked by the will to make their voices heard, each author conveyed the longing for an Africa that met the cultural, social, academic, and financial needs of its people: an Africa for Africans in control of its own, unique cultural evolution. 


\section{Appendix: A Selection of Rare Texts}

\section{Abdoulaye Sadji. “Mirages de Paris: Préface.” Paris-Dakar 12 Jun. 1937: 5.}

C'est la qu'avec le temps et les loisirs inemployés, s'élaborait chez les sujets prématurément rêveurs le drame de grandes incompréhensions - statique incomprise des mœurs et coutumes, des traditions laissées dans la famille, dans le village, et qui ne devaient jamais s'harmoniser avec la vie décrite par les romanciers et les poètes : dynamisme également incompris de la vie civilisée, si nouvelle avec son code de tolérances et de recherche effrénée du bonheur.

L'étudiant se mettait en face de la structure sociale de son milieu. Elle le passionnait par sa forme invariable. Et alors il songeait souvent à lui porter atteinte. Il la flétrissait même par la parole en présence de camarades qui étaient de même avis, qui avaient les mêmes idées sur les tams-tams obscènes, sur le port archaïque des grands boubous, et sur ces plaines infinies, endormies, mortes, où la Vie naissait avec le soleil et mourait avec lui.

Et naturellement quand un bateau s'éloignait des côtes de Dakar, l'imagination de l'étudiant le suivait loin, loin, échafaudant au delà de l'horizon où se perdait la fumée du navire, des cités enchanteresses.

\section{Là tout n'est qu'ordre et beauté. Luxe, calme et volupté...}

De la le double processus auquel nous devons « Karim » et « Mirages de Paris ».

Ousmane Socé n'a choisi le titre de son second livre qu'au dernier moment. Il m'avait toujours parlé de « Panamite» (mal de Panam, mal de Paris, le mot « mal» étant ici synonyme de nostalgie, de regret, de désir languissant).

Pourquoi ce revirement ? Il faut croire qu'un cataclysme sentimental s'est produit en l'auteur. Il a cessé de voir dans les aspects et dans la vie de Panam, cet attrait prenant que l'on est obligé de préférer aux beautés du pays natal. Qu'est-ce à dire ? Ousmane Socé a été lui-même désillusionné par le contact direct et permanent avec des choses et des gens dont il rêvait jadis sur le basalte noir de Gorée. Ce que son imagination féconde croyait voir au bout de la voie humide où glissent les «fumées de mer ». Il l'a vu de ses propres yeux, et il s'y est lancé à corps perdu. Et si Fara, le héros du roman y laisse sa peau, lui, Ousmane Socé y abandonne ses élans immodérés et quelques-unes de ses résolutions les plus audacieuses.

Ce sacrifice de sa jeunesse et de son intelligence que fait bêtement Fara l'envoûté, pour avoir trop cru aux mirages de Paris, Sidia, le philosophe, s'y refuse. Il sait qu'on doit aller en France pour chercher de l'instruction et non une femme un bonheur durable : que le bonheur supérieur, on l'a dans son milieu quand on peut se rendre utile. Sidia reviendra dans son pays, avec un diplôme de connaissances étendues épousera une Sénégalaise noir cent pour cent et emploiera son instruction au progrès de sa race.

N'était-ce pas une conception de choses vraiment inouïes pour un étudiant de Gorée chez qui « civilisation » voulait dire « rupture totale avec le milieu ». 
« Mirages de Paris » est donc la réponse faite dans une forme admirable, à des questions posées tacitement par toute une jeunesse, la jeunesse noire des écoles, avide de sensations neuves, embarrassée de savoir la voie à suivre. Dagana (Sénégal). 22 Avril 1937.

SADJI A.

Le roman d'Ousmane Socé, « Mirages de Paris » est en vente chez Viale au prix de 15 francs.

\section{Mamadou Dia. "Fine analyse de la crise de conscience d'une génération." Paris-Dakar 20 Jul. 1937: 2.}

M. Dia Mamadou nous envoie cette étude intéressante du livre de notre collaborateur Ousmane Socé. Nous sommes heureux de la publier :

Avec Mirages de Paris, les éditions Sorlot nous font assister à une éclosion littéraire dont Karim est la première manifestation. Ousmane Socé, après avoir dépeint dans sa création précédente le type du noir semi-intellectuel, esclave des mœurs et des coutumes surannées, présente à ses lecteurs un personnage réélisant l'antithèse du premier. Fara est le Nègre instruit, ayant brisé les cadres de la tradition et du milieu social pour s'adonner à la poursuite d'un bonheur fugitif à travers une vie artificielle faite de rêves dorés. A bien méditer, sur son histoire, on découvre par delà la fiction littéraire, l'âme de l'indigène évolué en proie à la magie de l'Occident et torturée par une crise psychologique qui emplit d'angoisse toute une génération.

Notre conscience morale subit, en effet, une évolution que diverses influences expliquent. Les journaux, les romans, les spectacles laissent entrevoir un monde où la jouissance paraît être la loi suprême. Une disposition spéciale et caractéristique de noire époque renforce cette croyance erronée : la goût de rêver en nous permettant de délecter des joies factices surprime peu à peu le sens de l'effort, la notion des réalités concrètes et des possibilités matérielles, cède la place à l'idée insensée de l'insaisissable. Assoiffés d'un bonheur dont nous plaçons la sources hors de noue et hors de notre milieu matériel nous vivons comme notre halluciné Fara d'images dont le pouvoir séducteur ne laisse pas de nous ensorceler. Et cette course effrénée vers un but qui semble reculer toujours fait naitre un sentiment d'insatisfait que connaît bien le héros du roman et qui se manifeste en nous par un état de surexcitation ou de malaise. L'aventure amoureuse de Fara ne pose-t-elle pas une brulante question d'actualité qui serre d'angoisse nos cœurs et nous plonge dans un abime d'incertitude amère.

Ce n'est pas le moindre mérite de M. Diop de nous faire prendre conscience du drame dont notre vie offre le spectacle et de nous prémunir contre les dangers.

\section{III. "La conférence de M. Diop Ousmané Socé a remporté un succès triomphal à la Chambre de Commerce." Paris-Dakar 3 Aug. 1937: 1.}

M. Diop Ousmane Socé nous avait déjà bien démontré que l'on peut fort bien, après avoir passé une partie de sa vie dans la brousse africaine, devenir un brillant élève passer avec succès ses examens à Paris et ... profiter des loisirs que laisse l'étude de l'art vétérinaire pour tenter sa chance dans les lettres.

Nous connaissons les talents d'écrivain d'Ousmane Socé ; samedi soir il nous a révélé ses dons de conférencier. Le sympathique Président du Foyer France-Sénégal, M. Papa Guèye Fall avait eu l'heureuse idée de cette belle réunion. Le sujet " Impressions d'Europe » sujet vaste et difficile, M. Turbé, président de la Chambre de Commerce de Dakar, présentait au public (et quel public) 
plus de quinze cents personnes se pressaient dans la grande salle de la Chambre de Commerce, le Président de la réunion, M. Léopold Senghor, professeur au Lycée de Tours et le conférencier.

M. Senghor prenait ensuite la parle et rendait délicatement en réponse aux paroles de M. Turbé hommage au personnel enseignant du Lycée de Dakar.

Puis pendant plus d'une heure, M. Ousmane Socé, dans un silence religieux parla.

Avec beaucoup de facilité, il nous exposa non seulement ses impressions d'Europe mais encre toutes les réflexions que peuvent lui inspirer la comparaison des civilisations européennes et africaines.

Avec finesse il a su dégager le pour et le contre, le bon et le mauvais de chacune de ces civilisations ; s'il explique sans fausse pudeur l'infériorité technique de l'africain et ses défauts, il sait, par contre aussi exalter les belles qualités de sa race et la revanche qu'elles donnent parfois au noir sur l'européen.

Il examine froidement, et fait le point de l'évolution actuelle de l'Afrique ; il ne craint pas de donner des conseils, et estime qu'il manquerait à son devoir s'il ne disait pas toute la vérité à ses frères. Et c'est la crânerie même avec laquelle il parle qui lui valut une ovation comme jamais le plus populaire politicien n'en eut à Dakar.

\section{Ousmane Socé. “Impressions d'Europe.” Paris-Dakar 3 Aug. 1937: 2.}

Monsieur le Gouverneur, Mesdames, Mesdames, Mesdemoiselles, Messieurs,

Voici quelques jours j'ai accepté de vous entretenir de mes impressions d'Europe. C'est un sujet plein de promesses que j'imaginais attrayant, mais à la réalité c'est un sujet décevant qui n'a présenté d'attraits qu'en un seul de ses aspects, celui des impressions artistiques. Or le but de cette conférence veut que je glisse sur mes impressions esthétiques parce que j'en ai déjà parlé dans un roman et parce qu'aussi elles n'offrent pas beaucoup d'exemples pour nous.

J'ai voulu préciser ce point avant de commencer afin de prévenir l'ennui d'écouter « un donneur de conseils » au lieu d'un enchanteur.

Pourquoi sommes-nous partis de l'Europe ?

Mentions de Baudelaire poème dédié a « Maxime du Camp » parlant des voyageurs...

Des lors l'homme de l'Europe part, par rapport à l'homme de l'Afrique, d'un piédestal beaucoup plus élevé : il aura ainsi le loisir d'appliquer son intelligence à la connaissance des choses beaucoup plus élevées : ses découvertes émerveilleront l'homme d'Afrique, qui ne se doute pas que, parti du même piédestal, il aurait, lui aussi, accompli les même merveilles : sa faiblesse vient, en effet de ce que ses ancêtres n'ont pas laissé trace de leurs expériences par la parole écrite. Le peu de leurs connaissances qui lui apporte la tradition orale est si faible que l'on peut énoncer que toutes les générations noires disparaissent avec leur expérience et leur savoir.

Il faut alors, à chaque génération africaine, recommencer le même geste de l'homme qui s'élève au-dessus de sa condition première que chaque génération ne peut arriver à dépasser que de très peu, le stade de civilisation atteinte par la précédente. D'où l'impression de stagnance que l'on éprouve lorsque l'on considère l'évolution de notre pays. 
Par conséquence, la première idée qui se dégage est que dans la lutte économique et j'entends par économique tout ce qui matériel, intellectuel ou artistique formera un élément de notre patrimoine dans la lutte économique, dis-je, notre devise doit être « acquérir » mais surtout épargner.

Au point de vue du développement de notre élite et l'éducation de notre masse, le travail à accomplir est énorme par rapport à l'Europe. Il n'est pas impossible pour cela. L'on ne peut que rendre hommage au Gouverneur général en considérant l'œuvre qu'il a réalisé dans ce domaine, néanmoins nous avons encore beaucoup de besogne. En nous ferons appel à la collaboration de l'élite indigène de tous ceux qui sont... de l'éducation africaine. Sans doute l'appartient à l'administration, de multiplier les écoles primaires élémentaires de créer des bourses d'enseignement supérieur. Comme aux Antilles et permettre ainsi la formation d'une élite ; cependant, il est indiscutable que l'éducation des masses, voire même l'éducation de la jeunesse, n'auront leur pleine efficacité que si nous aidons l'action de l'Administration en créant par notre organisation une ambiance favorable au travail des jeunes et, par la même occasion, une ambiance où soit possible l'éducation postscolaire de la masse.

En Europe, le petit enfant qui revient de l'école trouve à la maison des parents qui s'intéressent à ce qu'il a appris dans la journée, l'interrogent sur ce qu'il a fait, rectifient les fausses idées et comblent les lacunes s'il y a lieu, l'obligent à repasser ses leçons et a faire ses devoirs ; nul doute que c'est la un rôle de premier plan dans la formation de son cerveau et de sa conscience et cependant ce rôle échappe au contrôle du maitre d'école.

(à suivre)

\section{Part II of "Impressions d'Europe":}

\section{“Conférence prononcée à la Chambre de Commerce le 31 juillet sous les auspices du Foyer France Sénégal (suite et fin).” Paris-Dakar. 6 Aug. 1937: 2.}

En Afrique à quelque exceptions près, rien de semblable ; parti de l'école, nul ne s'intéresse, à la maison, au travail du jeune écolier, personne ne l'incite à travailler, parfois même, s'il aime les études et que, de sa propre initiative, il entreprenne ce travail complémentaire, il se verra dérangé par de parents qui jugent plus utile de l'employer à des occupations où sa faible collaboration n'est pas indispensable.

En égard de la masse, l'administration a songé à l'éduquer par la création des cours d'adultes du soir pendant l'année scolaire. Je ne crois pas que ces cours aient attiré, comme ils le devaient, ceux à qui ils étaient destinés ; je me souviens même, dans certaine ville du Sénégal, que s'était les jeunes, régulièrement inscrits à l'école du jour, qui revenaient le soir aux cours d'adultes pour s'entrainer à l'examen du certificat d'études. Quel que soit le zèle de l'Administration, pour rendre viable cette institution, il nous semble que l'éducation postscolaire des masses n'aura son effet que si l'élite noir seconde les écoles officielles en créant une ambiance qui sollicite l'adulte de tout âge à prendre gout à la lecture, à réfléchir, à penser, à s'intéresser a tout ce qui se passe autour de lui, de par le monde. Pour y parvenir, il faut encore nous en rapporter à l'exemple européen ; il faut une organisation matérielle qui impose à l'homme de la masse la pensée, l'instruction et l'information ; les instruments d'une telle organisation sont les journaux d'information, les revues, les bibliothèques nombreuses et gratuites, le théâtre, le cinéma, les conférences.

Pour parachever cette éducation de l'enfant et de l'homme adulte, j'irai même jusqu'à dire pour que les élites indigènes ne perdent pas a chaque génération le bénéfice de leur culture en 
redescendant la pente qu'ils avaient gravie a grand effort, l'éducation de la femme africaine est devenue une nécessité très urgente. L'homme et la femme, dans tout peuple, sont deux éléments qui se complètent ; les qualités et défauts de l'un et d'autre retentissent sur les enfants et même sur la valeur humaine de la société où vivent l'homme et la femme considérés.

Or, en Afrique si l'homme évolue tous les jours, prend des qualités et des défauts nouveaux, la femme, en général, reste stationnaire. Certes la société sénégalaise a sa civilisation a elle, une civilisation négro-arabe qui compte des siècles d'existence; elle a ses faiblesses (architecture élémentaire, ignorance de la peinture, musique embryonnaire, culture religieuse très développée mais manque de culture encyclopédique) ; elle a aussi ses qualités qui sont très belles ; hospitalité, généreuse fraternité, dédain du lucre et de tout ce qui n'est pas valeur normale. La femme noire est la conservatrice de cette civilisation stagnante, immuable, peu amoureuse de nouveau. Seulement qui n'avance pas recule et comme par ailleurs, dans le mode, on marche a très grands pas, la femme noire fera, de plus en plus, figure de retardataire ; elle s'est laissé distancer et par les autres femmes des autres parties du monde et par l'homme noir qui, lui, évolue sans contrainte. Il s'ensuit un déséquilibre entre deux compagnons dont l'accord parfait et le parfait équilibre sont les conditions d'une bonne formation de l'enfant noir, c'est-à-dire de l'homme noir de demain.

Cet état de chose, outre qu'il rend plus difficile l'éducation de la jeunesse, met dans une situation déconcertante l'homme africain qui ne trouve pas de compagne à son image, ou du moins la femme noire devient une force d'inertie contre quoi se heurte et se brise très souvent toute acquisition que l'homme noir a fait en essayant de s'élever dans la voie du progrès.

Nous voyons ainsi l'importance que présente l'éducation active de toutes nos femmes quelles que soient leur confessions religieuses. C'est un problème vital. Si on n'y apportait pas de solution ou bien l'évolution de ce pays serait vouée à l'échec, ou bien notre société de demain ne sera pas un édifice équilibré, à la solidité durable, mais un monstre disproportionné où l'homme sera très mal à l'aise.

Quant à l'organisation sociale nous hésitons presque à comparer l'Afrique à l'Europe. L'Europe, chez touts ses classes sociales, possède une forte organisation, privée, professionnelle et politique. Dans ces divers organismes les individus luttent et agissent selon des idées générales bien précises, vers un objectif déterminé.

En Afrique il semble que la marche en avant soit moins sure en son but. Presse, doctrines sociales, voire mêmes revendications sociales varient d'une ville à l'autre, d'un quartier à l'autre et chez la même personne d'une saison à l'autre. Il y a une inquiétante instabilité intellectuelle et d'opinions.

Cependant, tous veulent le bien public - et c'est là le drame - car chacun est convaincu de bien faire et reste irréductible en ses opinions ; des lors, les efforts se dispersent, se contredisent, s'annulent ; tout le monde lutte, seulement la résultante de ces forces sera négative et parfois nuisible. Or, ainsi qu'on le dit en thérapeutique, lorsqu'on veut soulager un malade, le premier soin qu'on puisse lui faire, c'est « Primum non nocere » Ne pas le nuire ; si l'on intervient pour aggraver le mal, il aurait mieux valu rester dans l'expectative.

Le redressement qu'il nous faudrait faire dans l'ordre social, devrait consister: 
1. En une entente sur des idées générales précises qui guideraient notre action non pour une semaine ou l'espace d'une revendication, mais pour une cinquantaine d'années sinon un siècle.

2. Une division très nette du travail, chacun s'occupant de la besogne pour laquelle il présente de réelles capacités.

3. Moins de polémiques, mais plus de travail et d'action.

Monsieur le Gouverneur.

Mesdames. Mesdemoiselles. Messieurs.

Tout le long de cette causerie nous avons comparé l'Europe à l'Afrique, celle-ci jouant toujours le rôle de point inférieur de comparaison. Nous avons proposé tout le long de cet exposé la civilisation économique et technique de la vieille Europe à la jeune Afrique qui est en pleine évolution et qui se demande avec inquiétude dans quel sens elle doit guider sa marche. Nous serions incomplets si nous ne disions pas en même temps à l'Afrique de prendre garde de ne pas copier son modèle sans discernement aucun.

En effet si l'Europe est arrivée à une apogée du développement technique et économique que l'on peut considérer comme « mec plus ultra » de ce que les hommes ont fait de tout temps dans cette voie, il n'en est pas moins vrai que le progrès moral n'a pas suivi le progrès technique. Des voix autorisées parlent de stagnation morale, d'autres plus pessimistes, vont jusqu'à dire régression morale. Écoutez le docteur Carrel dans on livre intitulé « L’homme, cet inconnu »...

Le monde où on vit l'esprit des hommes d'aujourd'hui n'est nullement celui de leurs ancêtres. Devant les triomphes de l'intelligence qui nous importe la richesse et le confort, les valeurs morales ont naturellement baissé. La raison a balayé les croyances religieuses. Seules importent la connaissance des lois naturelles et la puissance que cette connaissance nous donne sur le monde matériel et sur les êtres vivants. Les banques, les universités, les laboratoires, les écoles de médecine sont devenues aussi beaux que les temples antiques, les Cathédrales gothiques, le Palais des Papes....

Il est évident que les hommes ont accompli avec foie la civilisation moderne. Ils sont venus rapidement des campagnes dans les villes et dans les usines. Ils se sont empressés d'adopter le monde de vie et la façon d'être et de penser de l'ère nouvelle.

Ils ont abandonné sans hésitation leurs habitudes anciennes, car ces habitudes demandaient un effort plus grand. Il est moins fatigant de travailler dans une usine ou un bureau que dans les champs. Et même dans les fermes, la dureté de l'existence a été très diminuée par les machines.

Les maisons modernes nous assurent une vie égale et douce par leur confort et leur lumière, elles donnent à ceux qui les habitent le sentiment du repos, du contentement. Leur agencement atténue aussi beaucoup l'effort demandé autrefois par la vie domestique. Outre la diminution de l'effort et l'acquisition du bien-être, les êtres humains ont accepté avec bonheur la possibilité de ne jamais être seuls, de jouir des distractions continuelles de la ville, de faire partie des grandes foules, de ne jamais penser. Ils ont apprécié également d'être relevés, par une éducation purement intellectuelle, de la contrainte morale imposée par la discipline puritaine et par les règles religieuses. La vie moderne les a rendus vraiment libres. Elle les engage à acquérir la richesse par tous les moyens, pourvu que ces moyens ne les conduisent pas devant les tribunaux. Elle leur a ouvert toutes les contrées de la terre. Elle les a affranchies de toutes les superstitions. 
Elle supprime la contrainte, la discipline, l'effort, tout ce qui était gênant et pénible. Les gens, surtout dans les classes inférieurs, sont matériellement plus heureux qu'autrefois. Beaucoup, cependant, cessent peu a peu d'apprécier les distractions et les plaisirs banaux de la vie moderne. Parfois leur santé ne leur permet pas de continuer indéfiniment les excès alimentaire, alcooliques, auxquels les entraîne la suppression de toute discipline. En outre ils sont hantés par la crainte de perdre leur emploi, leurs économies, leur fortune, leurs moyens de subsistance. Ils ne peuvent pas satisfaire le besoin de tranquillité qui existe au fond de chacun de nous. En dépit des assurances sociales, ils restent inquiets. Souvent ceux qui sont capables de réfléchir deviennent malheureux.

La civilisation moderne se trouve en mauvaise posture parce qu'elle ne nous convient pas. Elle a été construite sans connaissance de notre vraie nature. Elle est due au caprice des découvertes scientifiques, des appétits des hommes, de leurs illusions de leurs théories de leurs désirs. Quoique édifice « par» nous, elle n'est pas faite à notre mesure.

L'homme devrait être la mesure de tout. En fait, il est un étranger dans le monde qu'il a crée...

Et seule une connaissance beaucoup plus profonde de nous-mêmes peut apporter un remède à ce mal.

Et c'est ici que l'Afrique prend sa revanche ; pour cette fois, elle se compare avantageusement à l'Europe. Sa vieille sœur commence à s'apercevoir que toutes ses richesses matérielles ne la rendent pas heureuse ; elle s'aperçoit que son bonheur dépendra pour une large part de son perfectionnement moral qu'elle avait négligé dans ses conquêtes effrénées du monde de la matière. L'Afrique, elle, est encore pleine de scepticisme, de religions et d'idéal.

Il nous faut donc, en imitant l'Europe, profiter de la leçon de son expérience, ne commettons pas à notre tout la maladresse de négliger ces grandes forces humaines que sont les valeurs morales. Il nous faut discerner. Il nous faut nous connaître d'abord avant de construire et ne jamais nous oublier en construisant.

Et c'est ici que je répondrais à ceux qui nous reprochent d'écrire pour le plaisir de dire du male de notre pays. Si nous avons écrit Karim entre autres, c'était en quelque sorte pour faire d'abord une anatomie de nous-mêmes qui résumerait nos qualités et nos défauts. Nos qualités ; nos amis et les griots nous les répètent souvent mais nos défauts, et c'est tout naturel, personne ne vous en parlera. Il nous faut faire nous-mêmes une autocritique pour les connaître et pour ma part je considère indigne d'un intellectuel de tromper ses compatriotes comme un vulgaire flatteur; je considère comme un acte criminel de la part d'un intellectuel de mentir a ses congénères, de ne pas leur dire la vérité.

Commençons par la connaissance de profonde de nous-mêmes, de nos qualités, de nos défauts, de nos forces, de nos faiblesses et de nos véritables aspirations. En un mot, pour le monde nouveau que nous voulons créer, semons avec des graines qui soient non seulement viables sur le sol africain mais aussi des graines dont les produits seront des bienfaits pour le peuple noir.

La tache que nous devons accomplir paraitra impressionnante peut-être même, dans certains esprits, le doute a-t-il germé que nous en serions incapables ; mais il faut se dire que notre retard n'est pas « un vice d'État»; L'Afrique n'est pas en retard parce qu'elle est l'Afrique, elle l'est parce qu'elle n'a pas été ouverte en même temps que la France, l'Angleterre ou l'Allemagne aux grands courants de civilisation venus d'Orient, la Grèce, Rome et qui on pris la voie méditerranéenne. Son retard est donc « un vice de date » qui disparaîtra avec le temps. Regardez 
partout autour de vous, en Afrique, considérés le grand progrès réalisé en si peu d'années et vous ne douterez plus que l'Afrique marche à grands pas vers le redressement.

J'en ai terminé avec cet entretien. Je serais de mauvaise grâce si avant de vous quitter je ne vous remerciais pas tous, M. le Gouverneur, chères auditrices et chers auditeurs, de m'avoir fait la confiance de venir et l'indulgence de m'écouter.

En nous séparant, formons des vœux pour la prospérité de la France et de l'Afrique noire toute entière. Que ce pays progresse toujours par l'effort éclairé, courageux, persévérant de tous ses enfants, que ce pays accomplisse, dans la paix, son vrillant destin et avec, la France, dans la liberté.

\section{Léopold Sédar Senghor. "Le problème culturel en A.O.F." Paris-Dakar 8 Sept. 1937: 2.}

This passage was omitted from the version published in Senghor's first collection of essays, Liberté I, and was directly taken from an article he published in Paris-Dakar on January 6, 1937, entitled "Réflexions sur l'éducation: De l'assimilation,"

Vous voudrez me permettre de vous lire les lignes qu'au début de l'année j'écrivais sur l'assimilation :

«Assimilation ou non-assimilation, tel semble être le dilemme pour beaucoup. Je crois que la question n'est pas là, plutôt qu'elle est mal posée... Car qu'entend-on par assimilation ? C'est bien l'action d'être fait semblable, mais aussi de rendre semblable.

Je ne saurais mieux faire que de comparer le phénomène culturel de l'assimilation au phénomène biologique. Assimiler un aliment, c'est le transformer au point d'en faire sa chair et son sang, c'est s'accroître en absorbant des corps étrangers. On ne devient pas ail ou bœuf ; c'est le mil, c'est le bœuf qui devient notre chair et notre sang. Aussi une seule assimilation assimilante. Il s'agit d'assimiler, non être assimilé. Le moi a donc double sens : subjectif et objectif, passif et actif.

Ainsi de l'esprit et de la culture, l'éducation d'un peuple présuppose chez celui-ci une personnalité ethnique, une civilisation, si humble soit-elle - et aucun homme sérieux, ne saurait nier les civilisations africaines aujourd'hui. C'est là, dans cette personnalité agissante, la condition nécessaire de l'assimilation. Toute action suppose un agent, et d'autant plus puissant que l'action est plus efficace.

L'apport d'éléments étrangers n'est pas moins nécessaire. Les civilisations, comme les races, périssent de leur trop grande pureté. Très frappant est, à cet égard, l'exemple de la civilisation française. Le peu de matières dont elle est chargée lui fait un impérieux devoir de souvent se renouveler. Et toutes ses renaissances, si l'on y veut regarder de près, se sont faites sous des influences étrangères. Témoin aussi les civilisations africaines qui allaient croupissant, isolées des eaux vives de du reste du monde par les solitudes du désert et de la forêt.

Mais ces éléments étrangers ne doivent être qu'aliments. Ils enrichissent une civilisation, ils lui donnent autre qualité, non autre direction. Il s'agit d'avancer dans sa ligne, de se développer en restant soi, d'évolution, non de révolution. » 


\section{Denis Blanche. "Préface" Le congrès international de l'évolution culturelle des peuples coloniaux: Rapports et compte rendu (Paris: Bibliothèque nationale imprimés, 1938). ${ }^{1}$}

Ouvert au lendemain du Congrès de la Recherche Scientifique dans les territoires d'Outre-Mer, le $1^{\text {er }}$ Congrès international de l'Évolution culturelle des peuples coloniaux $(26,27,29$ septembre 1937) a été l'une des manifestations du Mois colonial de l'Exposition de Paris. Une brillante réception, offerte par MM. Marius Moutet, ministre des Colonies, et Gaston Monnerville, soussecrétaire d'État du Département, l'avait cordialement préfacé. Il s'est tenu dans l'enceinte de l'Exposition, sous la présidence effective de M. le Dr. Paul Rivet, professeur d'Ethnologie au Muséum national d'Histoire naturelle, assisté de deux vice-présidents, MM. Périer, délégué de la Belgique, et le comte da Costa Lobo, délégué du Portugal, ainsi que de M. Marcel Griaule, secrétaire général du Comité d'Organisation. M. Paul Crouzet, qui devait présider l'une des sections du Congrès, avait dû s'excuser au dernier moment. Le ministre des Colonies était représenté par M. Charton, inspecteur-conseil de l'Enseignement au ministère des Colonies.

Il convient de féliciter chaudement, au seuil de cet avant-propos, les organisateurs de premier Congrès international de l'Évolution culturelle des peuples coloniaux.

Leur entreprise, aussi bien, semblait vouée d'avance à un échec certain. Trop de facteurs concouraient à cet échec. Et d'abord le nombre seul des Congrès organisés à l'occasion de l'Exposition de 1937. Il y en a eu plus d'un millier! Il fallait compter en outre avec l'apathie bien connue d'une grande partie de l'opinion à l'égard des problèmes d'ordre colonial. Au surplus le programme de travail qui était tracé aux congressistes constituait une nouveauté dont on pouvait craindre que certains ne saisissent tout à fait ni la portée, ni l'intérêt, ni a plus forte raison, l'urgence. Enfin, se tenant dans la métropole, et, au début de l'automne, le Congrès ne pouvait bénéficier que d'un effectif réduit, puisque d'une part un grand nombre de ses participants éventuels séjournent ordinairement aux colonies et que, d'autre part, de nombreux visiteurs de l'Exposition avaient regagné les territoires d'outre-mer dès la fin de l'été.

Pourtant ni les deux présidents du Congrès, ni le secrétaire général du Comité ne se laissèrent se décourager; et ils avaient raison puisque ces assises mémorables se tinrent à la date fixée, se déroulèrent suivant le plan prévu et connurent un succès dont témoignent, imparfaitement d'ailleurs, le nombre et l'intérêt des communications qui composent le premier volume.

Avant d'évoquer ces trois journées, et pour permettre d'apprécier dans quelle mesure elles ont pu être fécondes, il convient d'esquisser à grands traits les objectifs qui conféraient une raison d'être impérieuse au Congrès culturel.

On a pu reprocher au titre de Congrès une certaine imprécision, mais l'accord est aisé - et cela surtout importe - sur les réalités que ce titre évoque, sur la signification du problème que posent ces réalités.

D'ailleurs ce texte, à notre humble avis, dit assez bien ce qu'il veut dire. Il dit cultivés, il dit évolués des peuples que l'on appelait jadis sauvages et naguère «primitifs ». J'entends bien que cela fait roide et sommaire justice de certaines idées classiques, admises encore en raison de leur commodité par de bons esprits. Ces peules « jeunes » auraient des fastes, une histoire, une évolution, mot qui n'a guère de sens que si l'on compte par dizaines et par centaines de

\footnotetext{
${ }^{1}$ Though not published until 1938, the Congress was held in Paris from September 26 - 28, 1937, shortly after Senghor delivered his speech at the Chamber of Commerce in Dakar.
} 
millénaires ? Ces peuplades « simples » seraient des sociétés authentiques, moins frustes qu'on ne veut bien le dire, moins aisées à comprendre, moins perméables qu'on ne le croit.

Poser ces donnés de fait revenait à justifier hautement les démarches de l'ethnologue, qui désire étudier avant leur mort ces innombrables civilisations moribondes, et qui les voit mourir avec tant de regret, quand elles pourraient « servir » encore. La suffisance de certains civilisateurs, qui n'ont pas fait d'ethnologie, condamne un peu vite une foule d'institutions éprouvées, en quelque sorte garanties, vérifiées même par le temps et, en tout état de cause, provisoirement utiles. Coloniser, on l'a dit, c'est civilisé. Certes, mais la politique de la table rase risque d'être gratuitement vexatoire sans être pour cela plus efficace. Procédant à l'aveugle, elle multiple les malentendus souvent blessants pour l'indigène, en tout cas elle s'expose à les multiplier, quand il serait si simple et si indiqué d'aller jusqu'à celui-ci en utilisant les voies naturelles d'accès qu'ouvre la connaissance.

Tout n'est peut-être pas à rejeter, en bloc, des coutumes et des techniques indigènes. Bien des choses, au contraire, sont à respecter, ne serait-ce que pour faire l'économie d'un dépaysement superflu. Par exemple, la tolérance bien comprise fait un devoir de s'enquérir, avant toute chose, des croyances morales, des croyances religieuses de chaque population, de chaque tribu, de chaque clan. Autrement l'action colonisatrice qui, pour porter ses fruits, doit être collaboration, se verra entravée, ralentie, annulée peut-être par de maladresses, des erreurs et des méprises, des froissements et des incompréhensions mutuels. C'est pourquoi Rivet a pu dire qu'il n'y a pas de bonne colonisation sans ethnologie bien faite. Pour agir sur l'indigène et le promouvoir sur le plan humain, pour utilement perfectionner ses techniques et pour réaliser dans un minimum de temps cette double promotion, il est bon de connaître à fond « le terrain » (entendez l'indigène et son apport culturel).

Est-il permis aujourd'hui d'ignorer l'effort considérable fourni à cet égard par l'ethnologie française ? Est-il sage, est-il prudent de ne pas mettre en œuvre les matériaux acquis ?

Dans les diverses parties de la France d'outre-mer et plus particulièrement en Afrique noire se poursuivent, depuis un certain temps déjà, des enquêtes méthodiques sur les populations locales. La place nous manque malheureusement pour citer seulement ici le nom de tous les chefs de missions, ou la liste des travaux qu'ils ont rapportés de leurs voyages. Qu'il nous suffise de rappeler que Marcel Griaule a dirigé quatre missions en Afrique, notamment la grande expédition transafricaine Dakar-Djibouti, et qu'il revient d'effectuer une prospection éthologique chez les Dogon des falaises de Bandiagara. En ce qui concerne l'Océanie par exemple, les ouvrages de Leenharte sur les Néo-Calédoniens sont désormais consacrés comme un modèle inestimable de sagacité et d'intelligente sympathie.

À vrai dire, tout n'est pas fait et, malheureusement, nous ne possédons pas encore, pour chaque peuple colonial, une monographie comparable, même de très loin, aux volumes que Leenhardt a consacrés aux Canaques. Mais ce qui est fait n'est pas négligeable et, tel quel, trace des devoirs impérieux aux colons et aux fonctionnaires qui entrent en contact avec les peuples coloniaux. Il serait anachronique de coloniser à tâtons, quand les lumières fournies par l'observation : scientifique permettent d'ores et déjà, en plus d'une colonie, de le faire à très bons escient.

Le Congrès de l'Évolution culturelle des peuples coloniaux - qui était du reste associé au Congrès international de la Recherche Scientifique dans les territoires d'outre-mer - allait donc permettre trois choses : 
1. Le ralliement d'un grand nombre de chercheurs et l'établissement d'une « somme» des résultats acquis en matière d'ethnologie coloniale ;

2. L'affirmation motivée des droits de l'ethnologie à être entendue et utilisée par l'autorité colonisatrice ;

3. La confrontation des points de vue sur l'usage pratique de ces tests, ce qui revenait à poser la question générale des moyens et des fins de la colonisation.

Dans toute la mesure possible, ce triple objectif a été atteint. Tous les spécialistes de la recherche sur terrain - colons, professeurs et instituteurs, missionnaires et religieuses, explorateurs et exploratrices, officiers, ingénieurs, commerçants - étaient sinon présents, du moins représentés au Congrès. Ils y rencontraient des ethnologues et des coloniaux éminents parmi lesquels MM. Rivet, Charton, Griaule, déjà nommés ; Delavignette, directeur de l'École coloniale, le pasteur Leenhardt, des représentants de l'Académie des Sciences coloniales et deux délégués étrangers, M. Périer pour la Belgique et M. le comte da Costa Lobo, pour le Portugal. De nombreuses autres personnalités, dont nous ne pouvons donner ici les noms, suivirent les travaux du Congrès avec un intérêt croissant. Enfin, et le président River tint à le marquer dans son discours inaugural, plusieurs usagers de la chose coloniale, c'est-à-dire les Français d'outre-mer, étaient venus prendre part à ces travaux.

L'atmosphère dans laquelle se déroulèrent les discussions était sympathique, parce que courtoise et objective. Je tiens à le souligner et on comprendra ce que je veux dire quand on songera que des questions aussi brûlantes que celles des Ulémas de l'Afrique du Nord purent être discutées dans le calme le plus parfait. Le mérite en revient au tact et à la hauteur de vues des membres du Bureau et tout particulièrement à l'autorité du Dr. Rivet qui suivit assidûment les séances.

Grâce au concours précieux de M. Charton et de plusieurs autres congressistes, qui voulurent bien présenter les rapports des absents, de nombreuses communications purent être examinées. On ne les trouvera pas toutes dans les pages qui suivent. Les difficultés présentes, que tout le monde connaît, nous ont contraints à en résumer quelques-unes, à en sacrifier d'autres. Est-il besoin de dire que nous le regrettons? Nous pensons toutefois qu'on ne lira pas sans fruit les pages qui suivent et dont les dernières reproduisent les vœux terminaux du Congrès. L'ensemble mérite, en France et ailleurs, l'examen des pouvoirs publics.

L’accord a été aisé sur les vœux essentiels.

Toute les observations recueillies concordaient sur deux points capitaux : ni les sociétés « inférieures » ne sont simples, ni elle ne sont indignes de la patiente et prudente inquisition qui seule les fait intelligibles à l'observateur étranger. Truismes, dira-t-on. Pourquoi ne pas, dès lors, traduire en actes ces évidences ; pourquoi ne pas multiplier les moyens de l'enquête et du déchiffrement? Pourquoi ne pas mettre à profit tout de suite, dans les rapports avec l'indigène, les indications, chargées de conseils, déjà recueillies par l'ethnologue ?

Une question a été plus controversée que tout le reste, au point d'avoir dominé les travaux du Congrès : c'est celle des effets auxquels doit aboutir le contact des peuples aux colonies. Bien qu'elle ait donné lieu à des débats quelquefois pathétiques, la question était trop vaste pour faire l'objet d'une communication écrite, elle reste encore trop ouverte pour avoir fait l'objet à un vœu. Aussi croyons-nous devoir résumer aussi fidèlement que possible l'un des principaux aspects de la controverse. S'agissant du destin culturel de la race noire ou, si l'on préfère, des peuples appartenant au groupe noir, deux thèses se sont affrontés, celle qui préconise le respect de la culture indigène, celle qui préconise, au contraire, l'assimilation progressive nu noir à

l'Occidentale. 
La thèse du respect des civilisations indigènes connaît une certaine faveur. Elle est en vogue parmi les amateur d'art « nègre»; elle sommeille au fond du cœur de certains amis des peuples coloniaux et de certains sociologues qui, dans l'intérêt de la science, regrettent presque de ne pouvoir conservait pieusement, fossilisées en quelques sorte, les civilisations indigènes; de nombreux voyageurs estiment que le monde serait monotone et ennuyeux si le même type de civilisation régnait sur tous les continents. D'autres personnes considèrent tout simplement que tous les types de civilisation se valent et d'autres vont jusqu'à penser que la civilisation se valent et d'autres vont jusqu'à penser que la civilisation occidentale est inférieur à telle ou telle autres.

Ces idées anti-assimilatrices furent reprises et rajeunies avec beaucoup d'autorité par un universitaire d'origine sénégalaise, M. Senghor, il contestait aux nations civilisatrices le droit d'uniformiser le genre humain, sous prétexte de le civiliser. Enseigner aux Noirs d'Afrique des humanités gréco-latines, ce serait méconnaître leur originalité foncière, brimer le génie de leur race, les détourner d'une autre humanité possible, plus conforme à leurs aspirations profondes et à leurs aptitudes congénitales. Leur appliquer le moule d'une civilisation qui n'est faite ni par eux ni pour eux, pour laquelle ils ne sont pas faits, ce serait commettre une erreur d'orientation, une véritable injustice pour aboutir finalement au métis culturel, revêtus d'un vernis, inassimilé par ce qu'inassimilable. D'où le devoir de rechercher les directions où s'engage d'elle-même la civilisation des Noirs et de les maintenir dans ces mêmes directions, tout en hâtant leur progrès.

Nous n'avons pas cru devoir souscrire à cette théorie séduisante. Il n'est pas question, selon nous, de substituer, du jour au lendemain, une civilisation de type occidental à toutes les autres. Même là où cette substitution semble s'imposer, pour des raisons d'humanité, il faut beaucoup de science, de conscience et de patience. Mais la "civilisation nègre" est un mot vide de sens et il n’y a pas de référence aux métis des États-Unis qui tienne. La "race nègre," entendue comme une réalité anthropologique et comme l'auteur collectif d'une civilisation donnée, est un mythe. "L'art nègre" en est un autre non moins sommaire, où l'on retrouve pêle-mêle une foule de productions plastiques, musicales ou chorégraphiques qui n'ont aucun rapport entre elles. Il est bon de respecter le Noir, meilleur de l'équiper, et de l'équiper largement, quelque dommage qu'en doive souffrir "l'originalité" chère aux amateurs de fétiches "nègres." Au reste, le problème n'est pas tellement un problème artistique. L'essentiel n'est pas d'obtenir le maximum de talent dans la production de poème ou de chansons. Il s'agit pour l'instant (et cela, le professeur Rivet l'a mis en lumière en des interventions décisives qui étaient de véritables leçons magistrales) de nourrir l'indigène, qui est sous-alimenté, de le soigner, parce qu'il est souvent malade, de l'envoyer à l'école. La colonisation serait vaine, si elle avait pour but de faire l'Afrique un musée, un immense conservatoire de "civilisations" originales.

Ces échanges de vues, que nous résumons sommairement, avaient le mérite de montre quels problèmes complexes pose le contact des peuples aux colonies, contact de groupes ethniques, d'entités sociales, de systèmes législatifs et d'institutions, de mœurs et de notions morales, contact de cultures. Mauss et Rivet ont été les grands initiateurs et sont encore les promoteurs de cet ordre de recherches, trop négligées jusqu'ici au profit du problème de la mise en valeur des choses. La mise en contact des hommes aboutira-t-elle à l'agréation, à l'opposition, à l'imitation réciproque, à l'adaptation, et par quelles voies, sous quels aspects variables?

« Pour répondre, à dit Maunier ${ }^{2}$, il faudrait posséder d'amples monographies circonstanciées, qui dégageraient méthodiquement et typiquement, les modes et effets de la mise en contact. Nous n'en avons quasiment point jusqu'à présent. Du moins peut-on tracer, en rassemblant les

\footnotetext{
${ }^{2}$ Réne Maunier, Sociologie coloniale (Paris: 1932) 13.
} 
notations des voyageurs et des observations, les grandes lignes des questions... C'est ce que j'ai voulu tenter. »

C'est ce qu'a voulu tenter aussi, à la faveur d'une documentation plus copieuse et plus récente, et d'une collaboration internationale, le Congrès culturel. Comment ne pas lui en savoir infiniment de gré ? Comment ne pas exprimer le vœu que ces travaux soient repris en des assises prochaines?

\section{Léopold Sédar Senghor. "La résistance de la bourgeoisie sénégalaise à l'école rurale populaire" Congrès international de l'évolution culturelle des peuples coloniaux: Rapports et compte rendu (Paris: Bibliothèque nationale imprimé, 1938) 40-44.}

On a souvent souligné l'accueil favorable que les populations d'A.O.F. ont fait à l'École rurale populaire. On n'a pas assez dit la résistance que lui oppose et lui oppose encore la bourgeoisie des " évolués », la bourgeoisie sénégalaise plus que les autres, qui donne le ton aux autres. Elle est frappante pourtant la quasi-unanimité du mouvement. Elle trouve son expressions la plus nette dans les journaux dirigés ou inspirés par des indigènes : Le Périscope africain, l'A.O.F., Le Progrès, le Jeune Sénégal. Un journal comme le Périscope africain a pu changer de directeur politique, même de politique, sa position devant le problème n'a pas changé.

Quand on reconnu cette résistance, on en a trop souvent donné des raisons quelque peu simples. D'aucuns ont cru découvrir que « l'hostilité de l'indigène se mesure à son instruction » - hostilité à la France et à tout ce qui est sain. Comment expliquer alors que la majorité des instituteurs et des indigènes sortis des Facultés métropolitaines défendent l'École rurale populaire? D'autres ont expliqué le mouvement par le fait que les Blancs, à la Colonie, n'exercent pas de métier manuel. L'explication vaudrait pour la brousse et les paysans. À la ville «l'évolué » a vu des Blancs travailler de leurs mains et il sait, comme le dit Le Jeune Sénégal, que tous ne sont pas nés dans des palais.

Pour saisir les raisons profondes de la résistance bourgeoise, il faut, auparavant, en connaître la nature et en distinguer les limites ; car elle ne va pas sans nuances.

Is se trouve, il est vrai, des exaltés qui ne voient dans toute école rurale, qu'un « foyer d'obscurantisme ». Mais les plus pondérés, sinon la plupart, se défendent d'être les adversaires d'un enseignement africain et pratique. Dès 1934, Pierre André écrit, dans le Périscope Africaine: "Nous applaudissons de toutes nos forces au programme d'enseignement rural élaboré par M. le Gouverneur Général et dont nous ne saurions tarder à constater les heureux résultats, malgré le peu de temps qui s'est passé depuis sa mise en application ». Il va même jusqu'à déplorer « qu'il n'ait été rien fait ou presque pour améliorer l'enseignement professionnel » $\left(P . A .1^{\text {er }}\right.$ déc. 1934). Trois ans après, malgré les déceptions accumulées des « évolués », on peut lire dans Le Progrès, un journal d'avant-garde : Cette école (l'école normale de Hatigougon), dont les élèves deviendront, dans peu d'années, les meilleurs guides de l'artisan et du paysan noirs, répond, au contraire, à une nécessité, la substitution aux vieilles méthodes de culture de celles plus modernes afin d'augmenter le volume des récoltes et d'alléger la tâche du travailleur. Je ne vois, dans cette œuvre, aucun but néfaste. » (P., 22 mai 1937.)

On ne saurait nier la sincérité de ces déclarations. Elles appellent toujours, je le reconnais et le souligne, une contre-partie. L'école rurale populaire serait une institution excellente, à condition qu'elle ne sortît pas du village, qu'elle ne gagnât pas la ville. On obstinément hostile à l'adjonction d'heures de travaux manuels et agricoles dans les écoles urbaines. Même l'éducation physique n'y rencontre que peu de faveur. Mais que veulent nos « évolués »? Il n'est que de les 
écouter. Avec une particulière insistance, ils ont présenté leurs vœux à M. Marius Montet, ministre des Colonies, au cours de son voyage au Sénégal en 1936. Je ne veux retenir ici que ceux du « Foyer-France Sénégal », qui est l'association culturelle la plus représentative et la plus digne en même temps de son nom. Et parmi celui-ci : « Le Foyer France-Sénégal émet le vœu que les programmes métropolitains soient appliquées dans les communes de plein exercice. » Et cet autre qui concerne le recrutement des maîtres : «Le Foyer France-Sénégal émet le vœu que les bourses d'école normale primaire métropolitaine supprimées en 1928 soient rétablies au budget général ». C'est dire que la bourgeoisie demande, pour les villes, l'assimilation scolaire.

Les causes de cet état d'esprit? Il y en a de lointaines et d'actuelles. Celles-ci sont d'ordre politique ; celles-là d'ordre culturel pur autant que l'on s'occupe de culture.

Il faut se rappeler que dès la Restauration, il y a un enseignement organisé au Sénégal - et je ne parle pas de l'enseignement coranique --, une école secondaire à côté des écoles primaires élémentaires. Jusqu'à la loi de séparation, ces écoles furent tenues par les missionnaires et par le Frères de Ploërmel. Les fils de famille fréquentaient l'École «secondaire », plusieurs - des métis surtout - obtenaient des bourses pour la Métropole, d'où ils revenaient, avocats, médecins, officiers, etc. Il y avait un esprit « École secondaire », d'où l'esprit des maîtres n'était pas absent. Or ces maîtres avaient une conception bien connue de la culture, par suite, de l'enseignement. C'était la vieille conception des collèges jésuites d'avant 89 et que résistait encore, des les lycées métropolitains, à l'assaut des partisans des « Écoles centrales ».

La culture consistait dans l'étude de la composition et de l'élocution ; d'autre part, dans l'application de l'intelligence discursive à l'analyse des concepts. C'est ce que j'appellerais une conception scolistico-rhétorique de la culture. Et celle-ci était renforcée, chez notre bourgeoisie, par le goût du bien dire commun aux méridionaux, ainsi que par un reste de répugnance ancestrale pour les sciences expérimentales et exactes. Il s'y ajoutait, dans le même sens, l'influence de l'enseignement coranique.

Nous pouvons, à présent, comprendre ce qu'était cet esprit « École secondaire » qui a persisté jusqu'à nos jours et dont sont imprégnés les " évolués » pour la plupart, même s'ils n'ont pas dépassé le C.E.P. Plus qu'une conception scolastique, c'est une conception rhétorique formelle de la culture. Il répugne à ce qui est concret et pratique, peut-être à ce qui est africain, ce qu'il y a de bourgeois, d'utilitaire dans l'esprit des «Écoles centrales» le touche peu. Sans doute admiret-on le savoir encyclopédique ; mais, à l'ingénieur agronome, on préfère l'avocat. On retrouve cet esprit dans les deux associations culturelle les plus en vue : « Le Foyer France-Sénégal » et « La Fraternelle Musulmane »; assez métissé, dans la première, de bon sens bourgeois.

Rien d'étonnant, dès lors, que notre bourgeoisie ne comprenne pas le mouvement culturel francoafricain, dont l'école rurale populaire est une des expressions. Le mouvement est né d'une conception toute moderne de la culture. Celle-ci consisterait à " cultiver sa différence », comme le veut André Gide ; elle consisterait dans une réaction raciale de l'homme sur son milieu pour s'en servir comme instrument de perfection morale et intellectuelle; Nous voilà loin de la définition que nous donne Saguépar dans Le Jeune Sénégal du 15 mars 1937. Pur lui, il s'agirait de « connaître ce que c'est qu'un chêne..., un autobus, un phare », et non de " discerner une banane d'un noix de coco », il s'agirait de « connaître du nouveau », d'être « déraciné ». Évidemment, je prends un cas extrême. Le Jeune Sénégal garde l'esprit sénégalais le plus vieilli, mais il est caractéristique dans sa pureté. 
Les causes politiques de la résistance sont, peut-être, plus importantes encore. Plutôt les causes sociales et politiques. L'enseignement est un instrument de culture; c'est aussi une sorte de gagne-pain : il prépare à la profession. Notre bourgeoisie de ne l'ignore pas.

Elle sait que pour remplir certaines fonctions - dans l'Administration, en particulier - il faut posséder un diplôme identique à celui que délivre le Métropole ; que, d'autres fois, il faut subir un concours qui exige des connaissances identiques à celles de candidats métropolitains, d'où, poursuit-elle, la nécessité d'une assimilation qui permettra d'obtenir diplômes et connaissances identiques. L'assimilation doit être à la base, à l'École primaire : elle proscrit l'École rurale populaire et l'africanisation de l'enseignement en général. Ce souci de la profession, on ne le cache pas. Le « Foyer France-Sénégal » demande l'assimilation de l'enseignement primaire urbain et de l'enseignement primaire supérieur, les journalistes soulignent que c'est dans un but professionnel. Le brevet devient « un diplôme officiel qui ouvrirait à de nombreux élèves la porte d'un avenir plus modeste certes, que celui auquel ils pourraient prétendre s'ils étaient bacheliers, mais de nature cependant à leur assurer une existence convenable pour eux et leur famille. » (Périscope africain, 22 mai 1935).

Le social est lié au politique. Que les « évolués » demandent des « diplômes », ils pensent à leur gagne-pain, ils pensent aussi à prendre une place de plus en plus grande dans l'administration de la Cité. Ce n'est pas à dire qu'on tende au séparatisme ; tout au plus, à l'autonomie. Les déclarations à ce sujet abondent. Je pourrais citer Lamine Guèye et Louis Martin ; je cite « Un Nègre » : Si nous estimons que les Colonies ont besoin d'agriculteurs, d'ingénieurs urbains en village nègre, de forgerons et d'ouvriers de toutes catégories, nous sommes obligés cependant de demander que l'État permette aux coloniaux de former, pour leurs besoins, des intellectuels qui seront les élites appelés à participer à l'Administration des territoires qui leur appartiennent (Périscope Africain, 16 févr. 1935 G.M.). Ces lignes montrent que l'on sent ou croit sentir un danger politique dans la création des écoles rurales.

Il est vrai que le Gouvernement Général par ses paroles et ses actes, a fourni des prétextes, sinon des raisons à ces craintes - mon rôle n'est pas de trancher la question. Il a déclaré publiquement qu'il se plaçait non seulement au point de vue culturel, mais encore au point de vue social et politique. Il a invoqué la crise, les débouchés de moins en moins nombreux qu'offraient l'Administration et le commerce quand s'accroissait le nombre des diplômes indigènes ; il a préconisé le retour à la terre et aux arts indigènes ou résidait l'avenir économique du Pays. Dans ce but, il avait créé l'École rurale populaire.

La bourgeoisie de n'est pas laissé convaincre. Elle a loué l'habileté des discours officiels ; mais elle a cru distinguer plus clairement les intentions vraies du Gouvernement dans les commentaires et les conseils de certains colonialistes. En effet, dans un article des Annales Coloniales, du 20 novembre 1936, intitulé "Tristesses de l'Instruction obligatoire », M. Mommarson demande aux gouvernants de limiter l'enseignement dans les Colonies, à l'enseignement professionnel. Le 12 juillet 1935, M. Francis Mury publie, dans Le Courrier Colonial, un article qui a pour titre : «L'hostilité de l'indigène se mesure à son instruction ». Je ne commente pas ces articles. ON devine la réaction des journaux sénégalais.

Les faits, ajoute-t-on, traduisent mieux que discours et commentaire et conseils les buts derniers du Gouvernement. Lamine Guèye, dans L'A.O.F., du 28 mars 1936, récapitule les arrêtés et décrets « qui, tous les jours, rendent un peu plus sensible notre situation de citoyens diminués ». Il faut avouer, la liste en est assez éloquente. Le Périscope Africain fait de même, le 5 septembre 1936. Dans son article, Lamine Guèye n'hésite pas à établir une corrélation entre les textes cités et la règle que l'on s'est faite, d'après lui, de « dispenser l'instruction avec de plus en plus de 
parcimonie ». Car, depuis quelques années, les programmes des écoles urbaines pour certaines matières, ont été allégés ou modifiés dans le sens africain. La création d'une école rurale à Médina, faubourg de Dakar, avait surexcité les esprits. On voulait y voir la preuve flagrante que le Gouvernement poursuivait la « ruralisation » des écoles urbaines. Et de la taxer

d'obscurantisme et de réaction.

Telles sont, à mon avis, les causes profondes de la résistance bourgeoise. Pour être complet, j’y ai fait allusion déjà, il faut dire que l'École rurale populaire et l'enseignement franco-africain ont de partisans au sein même de cette bourgeoisie. Petite minorité, il est vrai, mais de qualité. Ce sont de jeunes instituteurs, des étudiants, des diplômés frais sortis de Facultés métropolitaines. Pour des raisons culturelles et sociales d'ailleurs non politiques, car eux aussi veulent que leurs congénères participent de plus en plus a l'administration de la Cité. C'est pourquoi, peut-être, les adversaires de l'École nouvelle insistent surtout sur ses dangers politiques.

C'est à expliquer leur résistance que je me suis efforcé, non à la justifier.

\section{Fily Dabo Sissoko. "Les Noirs et la Culture." Congrès international de l'évolution culturelle des peuples coloniaux: Rapports et compte rendu (Paris: Bibliothèque nationale imprimé, 1938) 116-122.}

Les Noirs et la Culture. Immense sujet. Pris au dépourvu, limité par le temps, nous ne l'abordons que de biais, par le truchement de quelques crayons venant à l'appui d'une courte esquisse historique et psychologique tout à la fois.

Il existe un charmant petit livre intitulé : Les États d'âme d'un Colonial, où, par le procédé des crayons dû au fameux duc de Saint-Simon, l'auteur - M. Delafosse - a réussi à fixer en traits inoubliables la plupart des « types coloniaux ».

Nous nous excusons de suivre les traces d'un tel maître.

Notre désir est de répondre à un point important du « Congrès culturel des Peuples coloniaux (section II) : l'évolution d'ensemble de la Culture des Noirs sous l'influence de la Colonisation.

Ceci dit, allons aux faits.

\section{COUP D'CEIL HISTORIQUE SUR LA CULTURE DES NOIRS (DE L'ANTIQUITÉ A NOS JOURS).}

a) Esope ( $5^{\mathrm{e}} \mathrm{s}$. av. J.-C.) - Esope était un nègre, comme son nom l'indique en grec, tout aussi bien qu'Homère, dans la même langue, signifie « aveugle ». [A. de Vigny].

Disgracieux, bossu par devant et par derrière, cet esclave phrygien ne payait pas de mine. Il était sans culture.

Son unique disciple, le bon, « l'inimitable La Fontaine ", revêtit la matière d'une parure de velours ou d'or, de brocart ou de paille, et lui donna une vie où, du plus grand au plus petit, chacun, aujourd'hui encore, se reconnaît et prend des leçons.

A eux deux, ils ont épuisé le sujet. Il est bon, il est juste, que toute étude sur la Culture des noirs débute par ce sommet. 
b) Légendes historiques et initiatiques. - Au cours de longs siècles, les Noirs du continent africain recherchèrent l'inspiration en eux-mêmes. Leurs croyances fondamentales, leur Panthéon, les rapprochent pourtant de peuples orientaux et des Celtes dont les légendes ont plus d'un point de ressemblance avec les leurs. [Cf. Légendes Celtiques adaptés par Jean DesChamps.]

Le cadre s'y prêtait. L'Afrique, continent massif, titanesque, isolé du reste du monde, a toujours été la terre des mystères.

D'un côté, le désert mouvant avec ses horizons illimités, son mirage décevant - [Antinéa, Foulcauld, E. Psichari, Laperrine] - et ses légendes symboliques - [ serpent de Régulus, Ouâgûdou-Bida, cyclope de Digna!]

De l'autre côté, la savane avec ses falaises, ses amas d'eau, ses fleuves monstres et ses légedges épiques - [Soundiata, Dia-Aliamen, Ouidraogo et Yennenga!]

De l'autre enfin, la Forêt, les grands Lacs, les Pics neigeux ! C'est là que naquirent toutes nos conceptions théogoniques. C'est là qu'elles ont conservé leur pureté originelle, leur grandeur, leur poésie et leur mysticisme qui n'a d'équivalent que dans le Rig-Véda lui-même !

Là, vivent les véritables Sages, les véritables guides spirituels de la Race Noire.

Qu'a-t-il donc manqué aux Nègres ? - L'Écriture tout simplement.

c) L'Écriture. - La structure de l'Afrique ne favorisait guère son introduction à l'intérieur du contient. Pour des raisons qu'on devine, les langues à flexion conviennent mieux à la propagation rapide des idées et à leur évolution que les langues idéographiques (hiéroglyphes, tamachek). Les vicissitudes de l'Histoire firent que la première de ces langues à flexion qui se soient introduites sur le continent, fut l'arabe. Grâce à l'arabe, l'Afrique noire a produit des hommes de premier plan, des météores. Nous allons retracer ici, très sommairement, la vie de deux d'entre eux.

d) Les météores. - 1. Mohammed Bagayoko (1524 - 1593). - Ce Malinké - d'une des 12 branches du clan Doumbia - fut par sa science et sa piété, un pilier d'Islam au Soudan. Il appartient à une famille de savants. Son père, Mahmoud, était un professeur émérite, théologien et jurisconsulte éminent. Il craignait Dieu encore plus. Ayant reçu d'autorité, de l'Askia Ishâq dont il avait flétri la conduite (en sa présence, en pleine mosquée, après le prône de vendredi, l'investiture de cadi, il en mourut de chagrin, la malédiction à la bouche : "Ishâq a privé mes yeux de sommeil et m'a contraint à veiller sans cesse. Que Dieu trouble son existence et lui envoie des sujets de préoccupation ! » [cf. Tarikh el-Fittâch p. 167].

Le saint homme repose à Djenné.

Ses fils : Mohammed et Ahmed, résidaient à Tombouctou. De grands savants tous deux.

Mohammed était : « jurisconsulte, théologien, érudit, vertueux, pieux, dévot. Il était d'une loyauté parfaite, d'une nature pure et fut le plus grand maître de son époque. Il ne croyait pas à la mauvaise foi des gens et avait toujours bonne opinion des autres. » [Tarikh. es. Soudan, p. 71 à 77.]

C'était un professeur incomparable. Ses émules étaient surpris de l'universalité de ses connaissances. El-Mâmer, professeur arabe (du Maroc), s'étant rendu à Tombouctou dans 
l'intention d'y recruter des disciples, fut subjugué à son contact et reconnut en lui un Maître. Il fut un exemple parfait de la Culture au service de la vertu.

Autour de lui, avant et après lui, Tombouctou, foyer intellectuel du Soudan avec Djenné et Dia, ne manqua jamais ni savants, ne de saints personnages.

Es-Sâdi, l'auteur du " Tarikh-es-Soudan », Sidi-Mahmoud Konté, autour du " Tarikh-el-fettâch », Ahmed-Baba (mort en 1627) dont la valeur était célèbre au Maghreb », étaient tous des Noirs, ou des métis d'arabes et de négresses. Ils appartiennent tous à des dynasties du savants et d'hommes pieux.

\section{El-Hadj-Oumar (1797-1864)}

En lui, s'est incarné la Culture au service de l'ambition. C'était un Fontauki - (ToucouleurTorado) d'une autre famille de savants, d'hommes pieux, orthodoxes farouches.

Fin lettré, d'une érudition immense, El-Hadj-Oumar se classe, et très haut, parmi les docteurs de l'Islam. Son œuvre capitale, la Kimâhou, rélève en lui le commentateur le plus éminent qu'il y ait eu du Mysticisme «tidjani».

D'une activité politique prodigieuse, sa réussite étonne encore : 28 rois abattus en 14 ans, de Diégounks à Hamdallahi! La défaite que lui infligea Faidherbe dans Médine (1857), ne le contraria nullement dans sa course à la conquête du Soudan, et le traité de 1860 ne fut autre chose qu'un second traité de La Tafner, plus avantageuse au Prophète Toucouleur qu'à la France.

Maître d'un Empire compris dans le triangle Dinguiray-Nioro-Tombouctou, avec Ségou au centre comme capitale, El-Hadj-Oumar aurait pu, s'il avait eu le temps, faire renaître l'antique Mali dans sa splendeur Partout où il passait, une fois la conversion obligatoire obtenue, il créait une école, installait un cadi, élevait une mosquée; et, aux points stratégiques, construisait un fort. Il lui arrivait souvent de mettre la main à la pâte et de porter des pierres.

Avec toute sa puissance, El-Hadj-Oumar était l'intégrité même ! Vivant en ascète, très simplement vêtu, il portait une tête massive sur un corps grêle. De toute sa personne, se dégageait un magnétisme puissant au service d'une volonté de fer.

Fétichiste, Malinké, petit-fils de l'un des chefs qui lui résistèrent à outrance, sans jamais se déclarer vaincus, nous n'avons d'autre intérêt à faire le panégyrique du Prophète Torodo que l'obligation de servir la Vérité. Au demeurant, nous sommes d'une tolérance absolue. Un tel homme ne pouvait manquer d'avoir des imitateurs.

El-Hadj Mamadou Lamine (1839-1886) Saracolé en fut un. Très cultivé aussi, très au courant de la civilisation européenne par un séjour fort prolongé à Stamboul, il eut, lui, le désir d'être

prophète en son pays! Après deux saisons d'agitation, il se brûla à sa propre flamme avec son fils Soybou dont l'attitude devant la mort excita l'admiration de Galliéni !

e) La place de Noirs dans la Culture mondiale. - Élargissions notre vision. Les A. Dumas, Toussaint-Louverture, Pouchkine, le professeur Blyden d'Oxford, étaient des nègres ou des métis de Blancs et de Négresses !

Il éxiste aux U.S.A. des universités nègres, des banques nègres. Il existe en France, une Revue du Monde Noir, dont les rédacteurs son des Hommes d'État, comme Sténio-Vincent d'Haïti, des administrateurs et linguistes distingués comme F. Éboué, de la Guyane. Tous Nègres. Les 
Goncourt, en couronnant Batouala "roman nègre », ont consacré, par un verdict éclatant, la capacité culturelle des Noirs.

Il y a plus.

f) La place des Noirs dans l'Évolution de l'humanité - a) Le professeur Bernebet-Moens, Hollandais, après s'être attaqué, pendant de nombreuses années, au problème des races aux U.S.A., arriva à ces conclusions :

1. Il n'y a point d'infériorité raciale absolue.

2. Les préjugés de couleur n'ont aucun fondement sérieux.

3. L'échelle des valeurs humaines sur le plan évolutif s'établit ainsi : Jaunes-Blancs-Noirs.

b) La psychologie de comportement a prouvé de son côté qu'entre les Blancs et les Noirs, il y a une démarcation de l'ordre de sept siècles : les Blancs évoluant sur le plan actif, les Noirs, sur le plan affectif. [Cf. prof. E. Mareault et prof. G.E. Monod-Herzen.]

Le problème de "l'évolution d'ensemble de la culture des Noirs sous l'influence de la Colonisation », n'est donc qu'UN PROBLÈME D'ADAPTATION.

Quels en ont été les fruits au Soudan?

C'est ce que nous allons voir à instant.

\section{L'ÉVOLUTION D'ENSEMBLE DE LA CULTURE DES NOIRS SOUS L'INFLUENCE DE LA COLONISATION.}

\section{Croquis Soudanais.}

En 1930, au cours d'un voyage à Dakar, une photographie nous est tombée sous les yeux. Pompeusement intitulée : un groupe d'intellectuels.

Les jeunes Sénégalais ont donc quelque prétention à la culture. Le fait existe au Soudan aussi. Voici les crayons des types les plus courants.

1. Type du « Bourgeois gentilhomme ». - Ce type est très répandu. Complètement illettré en sachant à peine lire et écrire, il en impose quand même par son allure et son maintien. Abonné à La ligue des Droits de l'homme et du citoyen, au J.O. et au journal local de son Parti, il aime, le soir, étendu dans sa chaise longue, à s'en faire la lecture. C'est un nouvelliste de haut vol. Ils sait comment Abd-el-Krim a été vaincu, comment Galandiou Diouf a triomphé de M. Lamine Guèye. Il sait que le Négus rumine pour prendre sa revanche sur le « duce». Franco est aux portes de Madrid, ça le met en émoi ! Il connaît les intentions financières de M. Vincent Auriol !

Il est naturalisé citoyen Français au travaille à le devenir. Il donnerait toute sa fortune pour ça. Sa fille n'épousera qu'un homme cultivé.

Ainsi s'écroule sa vie. Bonne chère, bon lit, dans une béate fatuité, à l'antipode de la Culture.

2. Type $d u$ " Faux-semblant ». - Ce type se distingue du précédent par des particularités vestimentaires qui en font un Nègre Blanc. Il passe dans la rue, sa badine à main, en coup de vent. Il va à la poste, pour prendre connaissance des Havas. Même tronqués, ils lui donnent des renseignements utiles.

Dans l'intimité, on le voit constamment penché sur de gros bouquins de Sociologie et d'Économie politique, ou sur quelques Encyclopédie Quillet. Il ne lésine point pour se procurer 
de tels ouvrages. Dans la discussion, il fait montre d'une volubilité surprenante. C'est une cascade de mots latins, grecs que sais-je ? Il ne dit pas la teigne, mais le tricophiton-tonsurans!, le saignement du nez, mais l'épistaxis !, le karité ou arbre à beurre, mais bassia-parki. Et gare à vous si vous ne comprenez pas : Il vous expliquera en latin!

C'est un maniaque qui prend ses fumées pour de la réalité.

3. Type du parvenu. - Celui-ci a une situation qui lui procure aisance et loisirs. Très sûr de soimême, sa politesse, c'est son bon plaisir, son modèle, le Blanc. À l'entendre parler, on se croirait en présence d'un Parisien. Il est musulman, mais se rase complètement, ou liasse un toupet de moustache sous le nez, par élégance. Sa carte, aux titres ronflants, dit bien qu'il est quelqu'un.

Il aime à recevoir dans un salon, où il a rassemblé, avec un goût douteux, toutes sortes d'objets.

La politique le hante ; de même que le journalisme. Sa vanité s'y étale en articles furibonds. Régentez toute la terre, lui procure un immense plaisir.

Sa faconde camoufle un égoïsme très bas, et une rouerie de garçon mal élevé. Mais de véritable culture, point.

4. Type du publiciste. - C'est un fort en thèmes D'idées personnelles, il n'en a point. Par contre, les idées de tous les hommes en place, quelque contradictoires qu'elles soient, les une par rapport aux autres, trouvent une résonance harmonieuse en lui. Il n'a de l'esprit critique à aucun degré. En lui, le sentiment de la dignité de la race a fait place, grâce à la culture qu'il a reçue, à une servilité à nulle autre pareille. Dans ses nombreux écrits, le Blanc a toutes les qualités du monde, le Noir toutes les faiblesses.

Type plutôt nuisible qu'utile, il contribue largement à la déformation systématique des croyances.

5. Type du dévoyé. - Celui-ci est généralement de basse extraction. Victime d'un complexenatif, il se sent mal à l'aise dans la Société indigène. Il s'est, sans l'ombre d'un scrupule, affranchi des coutumes ancestrales et des traditions familiales les plus vénérables. Occupé à danser le tango, il renvoie, sans sourciller, l'auteur de ses jours! Le pauvre bougre, si vous passez le mot, qui a cent kilomètres de route dans les jambes, s'affaisse et, la tête prise dans ses mains décharnées et noueuses, verse des larmes et du sang. - Que dirait la mère du pauvret!

C'est un pleutre que d'amères désillusions attendent au tournant de la rue.

6. Type du révolté. - Il y en a de toutes carrures. En général, le type moyen a réussi à faire la discrimination entre ce qui est, et ce qui devrait être. Il a mesuré le degré de résistance de l'obstacle placé sur son chemin. Pendant longtemps, pour trouver une issue, il a louvoyé. Peine perdue. Il en est arrivé à être passionné, bouillant. Toute son attitude, toute sa tenue se ressentent du désaccord qu'il y a entre ses perceptions et la réalité. Son jugement qui manque de sérénité, en est quelque peu faussé.

La culture, loin d'être un baume pour lui, joue l'effet d'un dissolvant.

7. Type de l'élite. - Des prétentions, de la jactance. De véritable élite : Point ! 


\section{CONCLUSION.}

La Culture, si elle se caractérisait seulement par l'acquisition des parchemins, est relativement accessible aux Noirs. Le jour où on le voudra, et comme on le voudra, les Noirs prendront d'assaut sans exception toutes les écoles de "France et de Navarre 》. Le jour où on le voudra, et comme on le voudra, nous fournirons des docteurs, des agrégés et des licenciés dans toutes les branches du savoir. Le Lagos, l'Ouganda et la Guadeloupe l'ont démontré. Mais, tel ne semble pas être le véritable but de la Culture. Un Sage, il y a bien des années de cela, nous a dit:

Souvenons-vous toujours qu'être instruit et intelligent font deux; et que si vous faites un pas du côté de l'instruction, il faut en faire deux du côté de la vertu.

La véritable Culture est donc un problème d'éducation. Elle a pour base la famille.

C'est la conclusion à laquelle est parvenue le Dr. Alexis Carrel. Écoutons-le :

«La société moderne doit améliorer, par tous les moyens possibles, la race humaine. Elle doit permettre à tous, mais surtout à l'élite, d'avoir une vie stable, de former un petit monde familial, de posséder une maison, un jardin, des amis. Le groupe social doit être assez petit, et la famille assez durable et assez compacte, pour que la personnalité des parents s'y fasse sentir. » L'Homme, Cet inconnu (p. 366-367).

Nous ajouterons seulement, ce que nous avons dit en 1926 : «Le Noir doit rester Noir, de vie et d'évolution. » (Le Soudan Français, Revue Europe, no. 74).

\section{FILY DABO SISSOKO}

Chef de Canton de Bafoulabé

\section{Ousmane Socé. “Le Danger.” Paris-Dakar 29 Sept. 1937: 2.}

Mon ami Léopold Senghor a fait l'autre soir une conférence très instructive sur le problème actuel en AOF. Il nous a dit que la bonne culture consistait à assimiler les apports extérieurs aux civilisations africaines et non à se faire assimiler par eux. Leur intervention dans notre destin doit être un «souffle ? » de renaissance : celle-ci a pour caractéristique un « bicéphalisme » dont les deux points de polarisation sont l'Afrique et la France. D'où la nécessite d'un « bilinguisme » qui nous permettait d'être en parfaite communication avec les deux sources de nos nourritures pour la civilisation afro-française que nous voulons bâtir.

Apres avoir énoncé ce principe général Senghor étudie, dans le détail, les programmes des divers enseignements, les manuels scolaires et l'orientation professionnelle des jeunes : il envisage aussi l'éventualité de l'étude d'une langue indigène au premier et au deuxième degré. Celle-ci servirait a l'expression artistique (littérature, théâtre... etc.) tandis que le français serait une langue scientifique et d'administration.

La raison sérieuse que le conférencier donne pour étayer son principe général est une pensée l'auteur nègre-américain Claude McKay « Plonger jusqu'aux racines de notre race et bâtir sur notre propre fond, ce n'est pas retourner à l'état sauvage, c'est la culture même ».

La raison sérieuse que Senghor donne pour appuyer le projet de l'étude officielle d'une langue indigène est la suivante : 
«L'élite est appelée à être exemple et intermédiaire. Quel crédit si elle s'est coupée des racines de sa race? Quelle compétence si elle ignore son peuple?»

Dans ce domaine des réalités ce qui correspond a cet esprit nouveau comprend les écoles rurales populaires, les manuels «Mamadou et Bineta » les écoles normales rurales, maisons d'artisanat, École supérieure d'enseignement technique.

La question est d'une importance capitale car le problème culturel n'est autre chose que le problème de l'avenir de notre race.

Je veux bien que le paysan africain reçoive une instruction élémentaire où l'enseignement de sa terre et ses moyens de l'exploiter soient prédominants : je veux bien que l'artisan africain n'abdique l'inspiration africaine et que la rénovation de son art se borne à s'appliquer la technique d'Europe à cette inspiration : je veux bien que la bachelier africain connaisse une langue indigène écrite au même titre que l'anglais et que l'allemand.

Mais le danger c'est déjà cet instituteur isolé qui se refuse de présenter des sujets d'élite au C.E.P. sous prétexte d' "éducation paysannale ». Le danger, c'est les hommes qui sont ennemis de notre évolution et qui emploieraient « l'esprit nouveau » à faire « machine en arrière » dans le but d'étouffer l'élite de notre pays. Un tel principe, sous leur pouvoir abouterait à ceci : nos frères noirs sauraient tout ce qui concerne l'Afrique mais ils ignoreraient les connaissances générales de mathématiques, de philosophie et d'histoire que tout homme des temps présents doit connaître. Ils ne seraient ainsi que des hommes de second plan, avec des horizons intellectuels bornés et c'est là le danger.

\section{Abdoulaye Sadji. “Utopie et Réalité.” Paris-Dakar 6 oct. 1937: 2.}

Une question qui n'a rien de nouveau et en soi parait enflammer la jeunesse intellectuelle sénégalaise depuis que notre ami et compatriote Ousmane Socé a, dans une conférence très apprécié, mis en relief l'une des entraves à notre évolution : le manque total de culture et d'éducation de la femme indigène. Cette question concerne l'attitude à prendre d'une part vis à vis de la tradition qui impose le mariage comme discipline sociale, et d'autre part vis à vis d'une tendance, qui, tout en abritant un besoin d'harmonie et un orgueil inavoué, semble exiger le choix d'une femme capable de nous aider à pousser la barque du progrès loin, loin.

Une agitation fiévreuse s'est emparée des jeunes sénégalais. Les uns, mariés aux époques de sagesse et de routine, ne connaissent plus de bornes à leur désespoir. Ils croient avoir gâché leur vie, perdu jusqu'à l'avenir brillant que le Sort taciturne, peut-être, leur réservait. Pourquoi ? Parce qu'ils ont épousé des " borom-diérés » incompréhensives, placées aux antipodes de la civilisation de du progrès... Les autres, plus narquois parce que libre encore de toute union consacrée, sont les animateurs des révoltes et des sombres regrets. Ils réclament avec force arguments, la vertu des mariages assortis qu'il faut arriver à réaliser. Fanfarons dans leur espèce, ils se croient dans la bonne voie qui, à les entendre, est le célibat hautain et systématique. Vivre tout seul avec son rêve en attendant que la femme sénégalaise instruite enfin vienne s'y modeler sans boursouflures.

Les unes et les autres retienne mal leur nerfs, partant, ils manquent de réflexion... et surtout de psychologie étant donné qu'ils croient possible l'instruction en masse des jeunes filles noires. Ils oublient ou ignorent leur propre histoire et celle de l'école africaine. Pour les attirer, eux les garçons, vers l'école, il a fallu démontrer par l'offre d'emplois lucratifs, que l'instruction n'était ni vaine, ni dangereuse. Adieu les durs travaux champêtres sous le soleil ardent, les petits métiers 
qui enfantaient des objets, ridicules, souvent invendables. L'École qui donnait aux plus intelligents la garantie d'une existence à l'ombre et dans l'aisance vit toutes les barrières levées. Elle s'emplit tant et tant qu'à la fin elle songea à fermer ses portes, craignant de pêcher par excès.

Maintenant on ne pense plus à cette condition qui a rendu possible le recrutement aisé des écoliers noirs. L'impulsion est donnée et même sans promesse formelle l'École reçoit en abondance les sujets dont elle a besoin. C'est qu'on s'abandonne toujours à l'illusion que l'enfant sortira d'un établissement qui lui donnera un diplôme et une place. Illusion difficile à vaincre et dont le service est inappréciable.

Ainsi l'intérêt, base de la plupart des démarches humaines, guide notre élan, mais peu à peu il se produit une évolution de ides.

Et c'est parce qu'il est arrivé à un stade où l'instruction lui semble un bien en soi, facteur indispensable de progrès, que l'intelligent sénégalais préconise l'envoi de masse des filles à l'école au nom du progrès et de la civilisation dont il a une soif ardente. Ce résultat qui est du à une longue expérience l'enferme naturellement dans le cercle vicieux des utopies.

Un examen attentif de la réalité montre cependant que pour amener les femmes au niveau des hommes il faut réaliser les conditions qui on permis de recruter facilement les garçons. A l'heure actuelle il est vain de prétendre à donne une instruction suffisante à la majorité de nos filles sil l'on n'attache pas à cette instruction un diplôme qui la sanctionne et surtout une place lucrative qui en montre l'utilité. Autrement dit il faudrait créer pour elles des cadres cariés qui semblables à des pôles d'attraction, détermineraient le mouvement intense vers l'école. Et plus tard lorsque le courant serait établi d'une façon permanente on pourrait restreindre ces cadres et même les réduire sans préjudice.

Il s'agit donc moins de blâmer la femme indigène inculte que d'étudier avec toute la compétence requise la possibilité de créer ces cadres d'attraction.

Nos jeunes intellectuels, s'ils méditent cette réalité, verront s'épanouir leur profonde utopie.

SADJI A.

\section{Ousmane Socé. “Autour du Congrès de l'Évolution culturelle des peoples coloniaux." Paris-Dakar 4 Jan. 1939: 1, 5.}

\section{Page 1 :}

Le compte rendu des rapports qui ont été envoyé au Congrès de l'évolution culturelle des peuples coloniaux, vient d'être publié. Ce congrès a été tenu à l'occasion de l'exposition internationale de Paris en 1937 dans le courant du « mois colonial». Les nombreuses questions étudiées se rapportent aux colonies françaises aussi bien qu'aux colonies étrangères. Celles plus marquantes, qui ont trait particulièrement à l'A.O.F. ont été traitées par Mme Le Goff (L'évolution de la femme indigène par l'école française) M. Fily Dabo Sissoko (Les noirs et la culture) ; M. Léopold Sédar Senghor (La résistance de la bourgeoisie sénégalaise à l'école rurale populaire).

\section{L'EVOLUTION DE LA FEMME INDIGENE}

Madame Le Goff donne les directives de l'éducation de la femme indigène en fonction du rôle que toute femme doit jouer dans la société « diriger une maison, être une bonne épouse, élever et 
éduquer les enfants ». Elle décrit l'éducation que la jeune fille indigène reçoit de ses parents et expose les motifs que rendent nécessaire l'éducation de celle-ci par l'école française.

\section{LA RESISTANCE DE LA BOURGEOISIE SENEGALAISE A L'ECOLE RURALE POPULAIRE}

Senghor dit que c'est « à expliquer la résistance de la bourgeoisie sénégalaise à l'école rurale qu'il s'est efforcé et non à la justifier ».

Si cette résistance en dernière analyse, a été bourgeoise, elle a pourtant été exprimée ici, par la presse dite prolétarienne. La réaction a été inspirée par l'appréhension de voir l'école rurale populaire en un instrument de sabotage de l'enseignement pur non spécialisé et non pratique.

\section{LES NOIRS ET LA CULTURE}

Ce n'est qu'un extrait du mémoire présenté par M. Fily Dabo Sissoko qui a été publié.

Néanmoins, le texte que nous avons sous les yeux, suffit à donner une information assez complète sur les idées de l'auteur.

Dans la première partie de son étude il fait l'historique de la culture des Noirs de l'antiquité à nos jours, d'Esope à Batouala.

Dans le même temps il détermine notre place et dans la culture mondiale et dans l'évolution de l'humanité. Dans la seconde partie Fily Dabo Sissoko traite de l'évolution des Noirs sous l'influence de la colonisation. Il nous fait entrer dans une galerie pittoresque où il expose quelques types soudanais de Noirs. Ses toiles ne sont pas des dessins haut en couleur, mais des croquis brefs des « crayons » selon sa propre expression.

Dans la troisième partie, nous avons la conclusion qui est celle-ci « Les Noirs doit rester noir de vie et d'évolution ».

Toute la première partie de cette étude est remarquable de documentation et d'interprétation. Nous y trouverons Es Sadi, l'auteur de «Tarikh es Soudan ». Sidi Mohammed Konté, auteur de « Tarikh-el-fettâch » Ahmed Bamba « dont la valeur était célèbre au Maghreb ». Mohammed Bagayoko, le « météore ». El Hadj Omar, « la culture au service de l'ambition ». Par ailleurs nous saurons que le professeur Blyden d'Oxford était nègre et que les travaux du professeur hollandais Bernebet-Moens ont aboutit à ceci :

1. Il n'y a pas de infériorité raciale absolue :

2. Les préjugés de couleur n'ont aucun fondement sérieux :

3. L'échelle des valeurs sur le plan évolutif s'établit ainsi : Jaunes, Blancs, Noirs

Dans la seconde partie, les Croquis soudanais, Fily Dabo, au fait met en antagonisme la culture des Noirs avant la colonisation et leur culture pendant la colonisation et sans qu'il l'ait écrit, il donne sa préférence à la première. 


\section{Page 5 :}

Mohammed était « jurisconsulte et théologien, érudit, vertueux, pieux, dévot... Il était d'une loyauté parfaite... Il fut le plus grand maitre de son temps... un exemple parfait de la culture au service de la vertu $»$.

Comparez ce portrait à celui du Soudanais moderne «type bourgeois gentilhomme » le type le plus répandu d'après l'auteur :

« Ce type est très répandu, complètement illettré, ne sachant à peine lire et écrire, il en impose quand même par son allure et son maintien. Abonné au « Ligue des droits de l'homme et du citoyen » au journal officiel et au journal local de son parti, il aime le soir étendu dans sa chaise longue, à s'en faire la lecture. C'est un nouvelliste de haut vol. Il sait que les Nègres ruminent pour prendre sa revanche sur le 'duce'. Franco est aux portes de Madrid : ça le met en émoi : Il connait les intentions financières de M. Vincent Auriol. Il est naturalisé citoyen français ou travaille à le devenir. Il donnerait toute sa fortune pour ça. Sa fille n'épousera qu'un homme cultivé.

Ainsi s'écroule sa vie. Bonne chère, bon lit, dans une béate fatuité, à l'antipode de la culture ». Et voici, d'après l'auteur le type de l' " élite » soudanais puisqu'il s'agit de " croquis soudanais ».

Type d'élite : des prétentions, de la jactance. De véritable culture, point.

Ainsi donc, l'auteur a été expressivement sévère à l'égard de ses compatriotes contemporains : au lieu qu'il a été excessivement aimable à égard de ceux du passé.

Sympathie et antipathie ou (pour) Noir à l'endroit d'autres Noirs, autour du problème de la culture.

Je connais personnellement M. Fily Dabo Sissoko. Un brave homme, je l'ai regardé vivre et travailler. Il m'a fait impression d'ascète et de sacrifice. Il est intelligent et possède de solides connaissances sur certaines questions. Seulement les autodidactes, dont je fais partie d'une certaine mesure, ont ceci de particulier dans leur labeur isolé, ils se considèrent, un peu, comme le centre de l'univers et regardent avec mépris tout ce qui gravite autour d'eux et ce mépris-là participe surtout de la rancœur d'un homme qui n'a pu se réaliser contre les universitaires et les diplômés.

Les autodidactes s'appesantissant à long loisir sur les études qu'ils aiment, deviennent en des points déterminés des puits de savoir. Si d'aventure, ils s'attaquent au problème de la culture, le sujet devient aussitôt le socle de l'univers. Il y a là une déformation de l'esprit. Je suis d'accord avec Fily qu'un homme instruit n'est pas forcément un homme cultivé mais j'avoue que j'ai souvent rencontré des hommes diplômés qui étaient fort cultivés et j'avoue encore que les autodidactes ont souvent une culture générale désordonnée et qu'ils se montrent parfois d'une nullité déconcertante sur telle branche du savoir.

Et d'ailleurs qu'est-ce que la culture ??

De nos jours, un homme est-il cultivé s'il est imbu d'humanités classiques, s'il est capable de penser juste et de façon personnelle sur les hommes et sur sa vie ? Ou bien l'est-il par l'université de ses connaissances ? Ou bien l'est-il si à défaut d'humanités classiques, il connaît bien l'histoire de son pays et de sa race ainsi que les œuvres, peu nombreuses, de ses congénères 
et aussi quelque connaissance générale ? Ou bien encore un homme est-il cultivé s'il a des connaissances générales suffisantes, du sens esthétique et s'il est capable d'autre part de vertu et pensée originale?

J'opterais pour cette dernière conjecture car, de nos jours, il est impossible, à l'image d'un Michel Ange ou d'un Bagayoko de loger dans une seule cervelle la somme des connaissances humaines : or toutes sont parties intégrantes de la culture, inséparablement. Dès lors, il y a au Soudan et ailleurs, plus de noirs cultivés que ne pense M. Fily Dabo Sissoko.

Je suis d'accord avec lui dans ses conclusions que « Le Noir doit rester noir de vie et d'évolution ».

L'aframéricain Cl. McKay, l'a aussi affirmé, il y a quelques dix ans.

Mais dans quelle mesure, cette pensée sera-t-elle réalisable dans le brassage actuel des races, des religions des mœurs et des concepts? Brassage qui, depuis 1850 va toujours s'accentuant dans une précipitation subite du cours de l'histoire humaine.

L'avenir le dira.

Mais il semble dès maintenant que l'évolution des peuples coloniaux, à quelque point de vue qu'en le considère, dépendra aussi bien de la volonté des hommes que d'un certain déterminisme historique.

Ousmane SOCÉ.

\section{Fily Dabo Sissoko. "Réponse à Ousmane Socé: A propos du Congrès de l'Évolution Culturelle des peuples coloniaux," Paris-Dakar 27 Jan. 1939 : 1, 5.}

\section{Page 1 :}

M. Fily Dabo Sissoko, chef de Canton du Niambia à Korokoto (Soudan) a bien voulu nous écrire pour compléter l'article documenté d'Ousmane Socé (1) sur le "Congrès de l'Evolution Culturelle des Peuples Coloniaux » et le rectifier sur quelques points.

Ce grand lettré soudanais, dont Ousmane Socé vantait à la fois, dans ce même journal, la vie d'ascétisme et de sacrifice non moins que son intelligence et l'étendue de ses connaissances, veut bien nous communiquer son point de vue, et nous somme certains que nos lecteurs cultivés apprécieront cette brillante controverse.

Par avance, nous lui en témoignons notre reconnaissance.

Monsieur Ousmane Socé vient de faire paraître un article intitulé : «Autour du Congres de l'Évolution Culturelle des peuples coloniaux» $»$ [... qui aurait du en toute simplicité et logique s'intitulé « Autour de Fily Dabo Sissoko».

En effet, cet article comporte deux cent quarante lignes de développement dont cent quatre vingt seize me sont réservées.

J'ai su la nouvelle par un coup de surprise, car le brave Ousmane Socé a négligé l'élémentaire courtoisie de m'aviser ou de m'adresser un numéro. 
C'est, au surplus, trop d'honneur pur ma chétive personne, si même - comme Ousmane Socé l'avance - je me crois, en traitant de la culture des noirs « le Socle de l'Univers ». En vérité, cela n'a rien à voir avec un Congrès international : et, de telles affirmations sont proprement abusives et témoignent d'un aplomb peu commun.

Vraiment, Dr. Ousmane Socé, là vous avez déçu le lecteur, il était en droit d'attendre mieux de vous.

Vous aviez sous les jeux un recueil de 226 pages, où mon rapport ne figure que pour 7 pages. Vous saviez que ce n'était là qu'un extrait, et vous le dites. Dans ce cas, la probité scientifique requiert de suspendre son jugement jusqu'à plus ample informé. Mais non, vous vous avez jeté sur cette pâture. Dites-moi, sur quels éléments d'appréciation vous pouviez vous baser pour jugement sainement un texte tronqué ? A moins que vous ne soyez doué du sens archi-rare de l'ubiquité comme il appert dans vos attaques. Car vous me connaissez si bien que vous savez diagnostiquer mon ascétisme, mes rancœurs et « tutti quanti »!

Non! Ousmane Socé. L'autodidacte que je suis n'a aucune prétention. Les lauriers des universités ne me gênent pas.

Ce qui me paraît grave dans cotre cas, déloyal même, c'est lorsque vous essayez de m'opposer à mes compatriotes soudanais par un double sophisme : 1 . en indiquant mes préférences et mes sympathies pour mes ancêtres, mes antipathies pour mes contemporains. 2. en me déclarant, face au Blanc, l'ennemi du Noir dans l'évolution culturelle.

\section{Page 5 :}

Dans l'un et l'autre cas vous perdez votre peine. Mon passé est ce qui répond pour moi. Le jeu d'ailleurs très ancien et la rue cousue de fil blanc. Marc-Antoine n'employa pas autre chose pour faire incendier les immeubles des meurtriers de Jules César. Le tribun en agitant de temps en temps, avec art, la tuque ensanglantée du dictateur, appelait à la fin de chaque période : «Brutus est un honnête homme ». Relisez votre « Concio - es », M. Socé.

Quant aux crayons, le « Bourgeois gentilhomme » figure dans un texte rédigé en 1925 et publié en 1928 (Cf revue «Europe », no. 4) Ce texte est intitulé « Le Soudan Français » et la conclusion que j'en ai tirée est aussi celle de mon travail sur les noirs et la culture. Elle est donc bien antérieure à celle de «l'Aframéricain » C. McKay. Les autres crayons ont été rédigés entre 1930 et 1932. Il n'y en a que sept de publiés. J'en ai une bonne demi-douzaine en réserve dont le «Censeur » $[\ldots]$ Ceci dit, passons au congrès.

Le Congrès s'est réuni au Haut Commissariat de la France d'Outremer, dans le pavillon de la synthèse (Exposition internationale de Paris 1937).

Ses assises durèrent du 26 au 28 septembre. C'est le premier Congrès international de ce genre et il a été l'une des manifestations du Mois colonial de l'Exposition de Paris. Quoiqu'il eut lieu au début de l'automne et qu'on put craindre la désaffection soit par fatigue, soit par apathie ou indifférence, il eut du succès. Cent et une personnalités se sont faites inscrire au nombre des congressistes : les rapports suivis ou non de discussions, trouvèrent tout le temps, un nombreux public.

J'ai sous les yeux, le premier volume paru des « Rapports et compte-rendu ». 
A ce congrès, la Hollande qui est pourtant l'une des nations colonisatrices du globe les plus importantes, n'a pas pris part, les îles britanniques, très peu. Nous ne parlerons ni de l'Italie ni de L'U.R.S.S.

D'autre part, sur 33 rapports publiés et précédés d'une brillante préface, 17, soit la moitié, sont consacrés à. A.O.F., où néanmoins le Dahomey ne paraît point.

En conformité avec les exigences édictées par le programme, tous les rapporteurs, à l'exception de six - qui se sont attaqués au problème même de la colonisation envisagé sous l'angle des réactions réciproques du « Colonisateur et du colonisé »- se sont cantonnés dans un point précis du problème sans toutefois s'empêcher le cas échéant, de donner des vues magistrales d'ensemble, comme nous lisons : « en dernière analyse notre œuvre si littérale dans ses intentions (sinon toujours dans ses développements) et son esprit, devrait aboutir « finalement» au régime du mandat de la Société des Nations, en pratiquant sincèrement la politique d'association qui gagne aussi plus surement le cœur des peuples par le respect de leur personnalité.

« La conception inverse semble reposer sur la pure abstraction de l' « homme en soi », nous conduisant vers une humanité en série, uniforme : après le français standard, europoïde, négroïdes ou sigmoïde, l'homme unique : (pourquoi pas la fleur unique) Or la nature est symphonie et non mélodie. »

Et, en note : « La conception inverse est née - a l'insu de ses tenants - de l'idée cléricale, de la création adamique associée à l'abus de l'esprit classique, qui voit ce qui unit mais oublie ce qui sépare ; à l'abus également de l'esprit cartésien dans ce domaine complexe des faits humains où l'élément effectif ou mystique est habituellement plus déterminant que la logique rationnelle. Elle aboutit finalement par l'abus de l'esprit classique et du rationalisme à une idée primaire qui tend à mettre en formules définitives, un monde ou tout est relatif. » (page 95) - (Court.)

On voit donc l'importance des questions soulevées au début à ce Congrès.

Nous y reviendrons. Car ces questions au font, conditionnent tout le problème de la colonisation.

La physionomie générale du congrès semble révéler un certain nombre de courants aux tendances diverses qui se ramènent toutefois à deux : tendances assimilatrices et les tendances adverses.

Il se trouve pourtant qu'il existe des colonies - véritables provinces françaises - ou le problème coloniale ne pose pas : même sous sa forme culturelle. (La Réunion et l'Inde).

Les tendances assimilatrices intégrales se sont faites jour parfois avec éclat dans certaines petites colonies relativement isolées : La Guadeloupe et la Guyane. Ces doctrines ont produit là, paraît-il des résultats miraculeux.

Il existe un dernier courant de tendances assimilatrices (Portugal ou l'idéal chrétien «l'humanité est Une », est mis à contributions pour des buts impérialistes et aussi pour empêcher l'émancipation des consciences. Au Cameroun, ces mêmes idées systématiquement, sont mises à contribution pour désorganiser les familles. Dans la Haute Côte d'Ivoire, sous couvert de féminisme elles poursuivent les mêmes buts. 
Dans les autres colonies et particulièrement en A.O.F, c'est - réserve faite pour les courants signalés plus haut - franchement la doctrine d'association qui prédomine, avec ici et là, quelques concessions bien calculées à la doctrine adverse.

La Belgique a manifesté sa participation du côté de l'art et de la technique. C'est une solide position qui présuppose des clartés sur la connaissance de l' " âme nègre ». (M. Delafosse).

Les complications les plus grandes se sont rencontrées à Madagascar et en Indochine.

L'Afrique du Nord, Maroc, Algérie, Tunisie) ne figure pas au congrès, quoique le difficile débat sur les «Ulémas » ait pu être discuté.

Mais la question qui semble avoir dominé les débats au point de n'avoir pu donner lieu à aucune communication écrite et dont tout le monde connaît l'ampleur et l'importance capitale, c'est la doctrine assimilatrice opposée à la doctrine adverse, anti-assimilatrice.

La première doctrine a été défendue avec brio, avec véhémence et fougue, par M. Denis Blanche professeur de la Guadeloupe. Pour son argumentation de fond, il fait appel à l'ethnologie et à l'autorité du professeur Rivet. Pour la démonstration de sa thèse, il rejette en bloc l'existence de la race nègre, de la civilisation nègre, de l'art nègre. Tout cela des « mythes » dit-il.

Pour se convaincre du contraire, sans chercher plus loin, il suffit de consulter le recueil. Nous lisons : « Nyambe, le Dieu « créateur » de toute vie, s'est éloigné de l'homme quand celui-ci s'est mis à tuer ses créatures ». C'est un indigène des tribus du Zambèze qui parle : un fétichiste (page 142) écrite par Marthe Kuntz.

Et celui-ci : « en ce qui concerne par exemple la préservation de l'originalité du style des arts primitifs : sollicités de fournir un motif de fresques devant être peintes par des artistes malgaches - l'artiste, reproduisant le dessin dans son ensemble - la Ste Trinité, Dieu le premier tenant entre ses genoux le Christ en croix - a en l'idée en quelque sorte géniale d'insérer comme par transparence la carte de Madagascar entres les deux personnes divines et de placer dans un angle le globe terrestre : double symbole par quoi le dessin se trouve non seulement enrichi mais encore renouvelé et recrée pour sa destination spéciale » (page 210).

Les tendances anti-assimilatrices ont été défendues par le professeur Léopold Sédar Senghor. Mais, il ne paraît dans les « Rapports et Compte-rendu », que par un article spécial : « La résistance de la bourgeoisie sénégalaise à l'école rurale populaire » (page 40).

C'est son antagoniste soi-même le professent Denis Blanche, qui, dans sa préface, présente ses idées « Monsieur Senghor contestait aux nations civilisatrices le droit d'uniformiser le genre humain sous prétexte de le civiliser. Enseigner aux noirs de l'Afrique des humanités grécolatines, ce serait méconnaitre leur originalité foncière, brimer le génie de leur race, les détourner d'un autre humanisme possible, plus conforme à leurs aspirations profondes et à leurs aptitudes congéniales. Leur appliquer le moule d'une civilisation qui n'est faite ni par eux ni pour eux, pour laquelle ils ne sont pas faits, ce serait commettre une erreur d'orientation, une véritable injustice pour aboutir finalement de métis culturels, revêtues d'un vernis inassimilé parce qu'inassimilable. D'òu le devoir de rechercher les directions ou s'engage d'elle-même la civilisation des noire et de les maintenir dans ces mêmes directions, tout en hâtant leur progrès »" (page 19). 
Cette position est également la notre et nous l'avons défendue dans nos travaux « Essai sur le totémisme soudanais » - « Loi de l'anticipation », - « Les Noirs et la Culture » (texte intégral) «Le Soudan Français » (revue « Europe » no. 74)

Elle est aussi celle du rapporteur du Niger, qui écrit : « Le Noir est un grand méconnu » (page 95).

FILY DABO SISSOKO

\section{Ousmane Socé. "Les noirs et la culture: Réponse à M. Fily Dabo Sissoko." Paris- Dakar 8 Feb. 1939: . $^{3}$}

Nos lecteurs ont suivi avec grand intérêt la brillante controverse soutenue par m. Ousmane Socé et M. Fily Dabo Sissoko, chef de canton du Niambia, au sujet de l'évolution culturelle des peuples coloniaux.

Le 4 janvier M. Ousmane Socé développait sa thèse: L'Enseignement de l'histoire montre que les noirs poursuivront leur évolution en s'assimilant l'essentiel de la civilisation et de la culture occidentale.

Le 27 janvier, M. Fily Dabo Sissoko exposait pourquoi il était hostile à l'assimilation, et préconisait que les noirs évoluent en restant fidèles à leur tradition.

Nous commençons aujourd'hui la publication de la réponse à ce dernier exposé, que nous fait parvenir M. Ousmane Socé.

Je voudrais écarter de ce débat l'atmosphère venimeuse de la polémique : aussi bien que passeraije de répondre aux reproches que me fait Fily Dabo sur la courtoisie et sur mon aplomb et à sa menace aussi de posséder dans ses fameux « crayons » une plaquette dite celle du "Censeur». Nous la lirons avec plaisir.

Dans sa réponse, Fily Dabo fait la mise au point suivante :

« Mon article documentaire aurait du s'intituler « Autour de Fily Dabo » en raison du nombre de lignes consacrées à ses « crayons».

C'est que dans la controverse sur l'évolution culturelle des peuples coloniaux, l'étude de Fily Dabo fut-elle tronquée par son éditeur, nous intéresserait davantage puisqu'elle traitait particulièrement de la culture des Noirs de l'A.O.F. L'importance matérielle que nous lui avons donnée dans le développement de notre article se justifie ainsi. Au surplus la probité scientifique me permettait de formuler une opinion sur les idées de l'auteur car les « crayons » sont absolus dans leur tendance comme dans leur conclusion : "Le Noir Soudanais contemporain de Fily Dabo Sissoko (1925 ou 1932) n'a pas de culture ».

Il n'était pas besoin d'être doué du don d'ubiquité pour entendre ce que Fily Dabo répétait, telle une litanie, au terme de chacun de ses croquis.

\footnotetext{
${ }^{3}$ This next was very difficult to read due to the quality of the films. I have noted particularly unclear parts in bold.
} 
Je n'ai pas essayé, M. Fily Dabo, de vous opposer à vos compatriotes soudanais : je me suis contente de leur mettre sous les yeux les dessins que vous avez fait d'eux. Ils avaient le droit d'en être informés et s'il y a opposition ce ne peut être que l'effet directe de votre travail.

Par ailleurs je ne crois pas qu'il faille relire sois « Conciones » ni même s'inspirer du machiavélisme (avant l'expression) de Marc Antoine pour citer, entre guillemets, la prose d'un écrivain. Enfin, les évocations latines sont très bien portées même par un Noir qui est contre la culture gréco-latine pour les Noirs.

Ce qui a déplu à M. Fily Dabo, c'est que je me suis élevé contre ses " crayons ». Or, quelque soit leur date, quel que soit le texte intégrale qui les précède ou les suit, je maintiens que les « crayons » sont quelque peu [...]. Je m'élève contre leur tendance à vouloir démontrer que du bas en haut de l'échelle des soudanais, ou des africains modernes on ne rencontre pas de culture. Le « bourgeois gentilhomme », «le parvenu », « l'élite » et demain sans doute le « censeur », sont des bulles d'air remplies de billevesées, mais de véritable culture, point, toujours point. C'est du début à la fin des « crayons » un refrain fatal comme la lumière du jour. Il y a là M. Fily Dabo Sissoko, une volonté de destruction un peu trop systématique. Pourquoi accumuler tant de décombres? A quoi l'homme privilégié qui serait seul à définir la véritable culture, ces décombres doivent-ils servir de piédestal ? Faudrait-il évoquer ici la ruse de Marc-Antoine?

La culture, comme toute chose ici-bas à ses degrés. On ne a refuse pas à des homme parce qu'ils la possèdent plus ou moins. Est cultivé à sa manière, même ce tirailleur, qui a fait un séjour hors de sa patrie de brousse bien qu'il ne parle qu'un français écorché. Il a élargi les horizons de sa conceptions de la vie et du monde : il en a une compréhension plus complète. La culture procède du général et non du particulier.

Mais revenons au Congrès.

J'avais demandé dans mon précédent article, à M. Fily Dabo de me dire ce qu'il entendait par culture. Il a répondu. Il a fait un compte-rendu des rapports du congrès : Il a rangé les diverses tendances en deux catégories : les assimilateurs et en anti-assimilateurs. (à suivre)

\section{SUITE :}

\section{Ousmane Socé. "Les noirs et la culture: Réponse à M. Fily Dabo Sissoko." Paris-Dakar 9 Feb. 1939: 5.}

Fily Dabo s'est classifié dans le groupe « des anti-assimilateurs », de ceux qui, d'après Denis Blanche, contestent au nations civilisatrices par la plume de Senghor « le droit d'uniformiser le genre humain sous prétexte de le civiliser - Enseigner aux noirs de l'Afrique des humanités gréco-latines, ce serait méconnaitre leur originalité foncière, brimer le génie de leur race, les détourner d'un autre humanisme possible, plus conforme à leurs aspirations profondes et à leurs aptitudes congéniales... »

Le problème qui se pose pour le peuple noir n'est pas nouveau. Voyons comment il s'est résolu chez les peuples de vieille civilisation.

C'est d'Afrique même (o paradoxe !) dans la vallée du Nil entre Memphis et Thèbes qu'il y a des millénaires commencèrent à se dessiner les linéaments de ce que nous appelons aujourd'hui la civilisation et que je confonds avec la culture. 
C'est un effort constant de l'homme à s'élever au-dessus de sa condition première. Au point de vue statistique il se dissocie en deux éléments : lutter contre les forces de la nature qui nous sont défavorables et faire un monde matériel meilleur : et aussi cultiver l'homme en développant ses tendances intérieurs à une conception spirituelle du monde. Toutes les acquisitions de cet effort constant constituent, dans le sens dynamique, à chaque époque donnée de l'histoire, la civilisation de l'époque considérée. (à suivre)

\section{SUITE ET FIN :}

\section{Ousmane Socé. "Les noirs et la culture: Réponse à M. Fily Dabo Sissoko." Paris-Dakar 10 Feb. 1939: 5.}

De Thèbes et de Memphis la civilisation passa à l'Assyrie et à la Chaldée, puis à la Phénicie et de celle-ci de Grèce. De la Grèce elle passa aux Latins et de ceux-ci aux peuples de l'Europe occidentale qui en sont, de nos jours, les dépositaires le plus avancés. Avec le XXe siècle la civilisation va enfin quitter le bassin méditerranéen, prendre la voie de l'Atlantique et de façon décisive se répandre jusqu'à nous. Je parle de la civilisation générale. Dans sa marche, de peuple à peuple, elle n'est, à chaque palier de son ascension, qu'une adaptation de ce qu'elle était dans le palier précédent. La civilisation grecque fut une adaptation de la civilisation phénicienne : la civilisation latine une adaptation de la civilisation grecque et la civilisation française actuelle une adaptation de la civilisation latine. Elle est gallo-romaine et non purement gauloise ou purement romaine.

Ainsi donc si l'on pouvait établir l'équation de la marche de la civilisation humaine, il faudrait sans doute écrire ceci :

« C'est une couche de métissages successif en fonction des grandes expansion militaires et commerciales de l'histoire : métissages successifs à degrés variables : ce que l'étranger apporte est en raison de ce que l'indigène a déjà reçu de son propre génie.

Un jour peut-être ce métissage culturel sera interplanétaire ».

Le cas particulier de cette équation, c'est que parfois l'étranger a été civilisé par l'indigène des invasions barbares.

Aux Assimilateurs comme aux anti-assimilateurs, je réponds ceci : Nous n'échapperons pas à cette loi de la genèse de la civilisation humaine ».

Notre civilisation à nous, la volonté des hommes mise en facteur sera eurafricaine, précisément franco-africaine. Pour qu'elle soit autre, il eut fallu que a tour de destin eut marché dans un autre sens. C'est de ce déterminisme que je signalais, en second lieu, à Fily Dabo. Notre civilisation eurafricaine ne fera pas aboutir l'évolution de l'humanité à l'homme unique. L'équilibre symphonique de la création n'en sera pas rompu. La symphonie persistera avec les ressorts liturgiques affectifs et politiques de chaque groupement humain. Quoique menacés, ces éléments-là auront toujours des survivances qui marqueront aux heures de crise surtout la différence entre les peuples. 


\section{Ousmane Socé. “L'évolution culturelle de l'A.O.F.” Dakar-Jeunes 29 Jan. 1942: 2.}

M. Ousmane Socé est assez connu de la jeunesse d'Afrique pour que nous n'ayons pas à rappeler ses titres littéraires. Son talent de romancier dont Karim a eu un succès qui a dépassé les limites du Sénégal.

L'article qu'il nous donne éveillera l'attention des jeunes qui nous le prouverons en nous faisant connaître leurs opinions sur la thèse de l'auteur.

Des problèmes qui préoccupent la jeunesse en A.O.F., l'évolution culturelle est, assurément, l'un des plus passionnants. Peu avant la guerre, un débat s'était ouvert à ce sujet dans la presse locale et la controverse qu'il suscitait à l'époque s'était close sans avoir épuisé la question ni abouti à une conclusion

Cependant il n'est pas suffisant que la jeunesse, divisée en deux tendances, soit satisfaite, de part et d'autre, d'avoir bien défendu une position. Une synthèse des diverses attitudes s'impose. Il nous faut la tenter en dégageant d'abord les grandes lignes des théories qui ont été exposées, en essayant ensuite de concilier ce qui vaut dans chacune d'elles pour définir une ligne d'entente

Mon ami Léopold Sédar Senghor, agrégé de l’Université, développait naguère son point de vue en ces termes:

« Enseigner aux Noirs d'Afrique des humanités gréco-latines, ce serait méconnaître leur originalité foncière, brimer le génie de leur race, les détourner d'une autre humanité possible, plus conforme à leurs aspirations profondes et à leurs aptitudes congénitales.

Leur appliquer le moule d'une civilisation qui n'est faite ni par eux ni pour eux, pour laquelle ils ne sont pas faits, ce serait commettre une erreur d'orientation, une véritable injustice pour aboutir finalement au métis culturel, revêtus d'un vernis, inassimilé par ce qu'inassimilable. D'où le devoir de rechercher les directions où s'engage d'elle-même la civilisation des Noirs et de les maintenir dans ces mêmes directions, tout en hâtant leur progrès. »

À la même époque dans une qui controverse qui m'opposait à notre compatriote Fily Dabo Sissoko, intellectuel soudanais, celui-là déclarait à la fin d'un article qui m'était adressé que cette position du professeur Senghor était aussi sienne. Il l'avait défendue dans ses travaux antérieurs : - Essai sur le totémisme soudanais - Loi de participation - Les Noirs et la culture.

C'est attitude est ce que nous appelions la tendance anti-assimilatrice.

Pour ma part je défendais un point de vue différent dont voici l'essentiel :

- Le problème qui se pose pour le peuple noir n'est pas nouveau. Voyons comment il s'est résolu chez les peuples de la vieille civilisation : c'est d'Afrique même, dans la vallée du Nil, entre Memphis et Thèbes qu'il y a des millénaires, commencèrent à se dessiner les linéaments de ce que nous appelons aujourd'hui la civilisation et que je confonds avec la culture. C'est un effort constant de l'homme pour s'élever au-dessus de sa condition première. Au point de vue statique, il se dissocie en deux éléments : lutter contre les forces de la nature qui nous sont hostiles, et faire un monde matériel meilleur, et aussi cultiver l'homme en développant son esprit et sa sensibilité, en subordonnant ses tendances inférieures à une conception supérieure, spirituelle et esthétique du monde. Toutes les acquisitions de cet effort constant constituent, dans le sens dynamique, à chaque époque donnée de l'histoire, la civilisation de l'époque considérée. 
De Thèbes et de Memphis la civilisation passe à l'Assyrie et à la Chaldée puis à la Phénicie et à la Grèce. De celle-ci aux Latins, puis aux peuples de l'Europe occidentale qui en sont, de nos jours, les dépositaires les plus avancés. Avec les XIX et XXe siècles, cette civilisation va enfin quitter le bassin méditerranéen, prendre la voie de l'Atlantique et se répandre à nous de façon décisive. Je parle de la civilisation générale qui nous a le plus affectés, nous et tout le monde contemporain. Je laisse dans l'ombre les civilisations d'Extrême-Orient.

Ainsi donc si l'on pouvait dans une question aussi peu mathématique que l'évolution humaine, établir l'équation de la marche de la civilisation, il faudrait sans doute écrire ceci: C'est une courbe de métissages successifs en fonction des grandes expansions militaires et commerciales de l'histoire; métissages successifs à des degrés variables. Ce que l'étranger donne est en raison inverse de ce que l'indigène a déjà reçu de son propre et qui est viable; un jour viendra peut-être où ce métissage culturel sera interplanétaire.

Le cas particulier de cette équation résiderait dans ce fait que parfois le conquérant a été civilisé par l'indigène (Les invasions barbares).

Nous n'échapperons pas à ce déterminisme de la genèse de la civilisation des hommes. La nôtre, la volonté des peuples mis en facteur, sera eurafricaine, précisément franco-africaine. Pour qu'elle soit autre il eut fallu que la roue du destin marchât dans un autre sens. Ainsi de beaucoup de peules avant nous et avec nous.

Jeunesse d'Afrique noire français le débat est ouvert. Pour une aussi importante question il nous faut trouver une synthèse des composantes valables des diverses attitudes. 


\section{Bibliography}

\section{LITERARY WORKS}

Césaire, Aimé. Cahier d'un retours au pays natal. 1947. Paris: Présence Africaine, 1971.

Damas, Léon Gontran. Pigments - Névralgies. Paris: Présence Africaine, 1972.

Diallo, Bakary. Force-Bonté. 1926. Paris: Nouvelles Éditions Africaines, 1985.

Diop, Birago. Les contes d'Amadou Koumba. Paris: Fasquelle, 1947.

Sadji, Abdoulaye. Ce que dit la musique africaine. 1936. Paris: Présence Africaine, 1985.

---. "Nini.” Présence Afrcaine. 1 (1947); 2 (1948); 3 (1948); 4 (1948): 647-666.

---. Nini: Mulâtresse du Sénégal. 1954. Paris: Présence Africaine, 1988.

---. Maïmouna. 1953. Paris: Présence Africaine, 1958.

---. Tounka. Paris: Présence Africaine, 1965.

Senghor, Léopold Sédar, ed. Anthologie de la nouvelle poésie nègre et malgache de langue française. Paris: PUF, 1948.

---. The Collected Poetry. Charlottesville: University Press of Virginia, 1991.

Socé, Ousmane. Karim: Roman sénégalais. 1935. Paris: Nouvelles éditions latines, 1948.

---. Mirages de Paris. 1937. Paris: Nouvelles Éditions Latines, 1964.

---. Contes et légendes d'Afrique noire. 1938. Paris: Nouvelles éditions latines, 1962

\section{CRITICAL TEXTS AND HISTORY ${ }^{1}$}

Ageron, Charles-Robert. "L'Exposition coloniale de 1931: Mythe républicain ou mythe imperial." Lieux de Mémoire, ed. Pierre Nora. Paris : Gallimard, 1997.

Bhabha, Homi. The Location of Culture. London: Routledge, 1994.

Blair, Dorothy. African Literature in French. Cambridge : Cambridge University Press, 1976.

\footnotetext{
${ }^{1}$ ANS - Archives nationales du Sénégal, Dakar; BNF - Bibliothèque nationale de France, Paris; CRL Center for Research Libraries, Chicago; IFAN - Institut Fondamental d'Afrique Noire, Dakar
} 
Blanche, Denis. Préface. Le congrès international de l'évolution des peuples coloniaux: Rapports et compte rendu. Ed. unknown. Paris: Bibliothèque nationale imprimés, 1938: 13-20.

Bouche, Denise. "Autrefois notre pays s'appelait la Gaule...: Remarques sur l'apaptation de l'enseignement au Sénégal de 1817 à 1960." Cahiers d'études africaines 8.28 (1968): 110-122.

Bourrel, Jean-Réné. "Le Lièvre et le Roi: La belle histoire de Leuk-le-lièvre de L.S. Senghor et d'A. Sadji." Notre Librairie 163 (Sept. - Dec. 2006): 43-48.

Brasseur, Paule. “A propos du Congrès International sur l'évolution culturelle des peuples coloniaux.” Journal des Africanistes. 49.2 (1979): 143-150.

Brousseau, Pascal. Vie et oeuvre de l'écrivain sénégalais Ousmane Socé Diop: Démonstration d'une injustice littéraire et intellectuelle, et révélation d'un monument caché de la littérature africaine. Diss. University of Virginia, 2004.

Cantier, Jacques, and Eric Jennings. L'Empire Colonial Sous Vichy. Paris: O. Jacob, 2004.

Chafer, Tony. The End of Empire in French West Africa. New York: Berg, 2005.

--- "Teaching Africans to be French: France's 'civilising mission' and the establishment of a public education system in French West Africa, 1903-30" Africa: Rivista trimestrale di studi e documentazione dell'Istituto italiano per l'Africa e l'Oriente 56.5 (June 2001): 191

Chafer, Tony, and Amanda Sackur, ed. French Colonial Empire and the Popular Front: Hope and Disillusion. New York: St. Martin's Press, 1999.

Conklin, Alice. A Mission to Civilize: The Republican Idea of Empire in France and West Africa, 1985-1930. Stanford : Stanford University Press, 1997.

Denjean, Sébastien. Fily Dabo Sissoko l'écrivain et le politique. Bamako : Le Figuier Présence Africaine - EDICEF, 2000.

Dewitte, Philippe. Les mouvements nègres en France, 1919-1939. Paris: L'Harmattan, 1985.

Dia, Mamadou. Mémoires d'un militant du tiers monde. Paris: Publisud, 1985.

Dogbé, Yves-Emmanuel. Négritude, culture et civilisation. Le Mée-sur-Seine: Éditions Akpagnon, 1980.

Genova, James E. “The Empire Within: The Colonial Popular Front in France, 1934 - 
1938,” Alternatives: Global, Local, Political, 26.2 (April - June 2001): 175-209.

Hill, Edwin. "Imagining Métissage: the Politics and Practice of Métissage in the French Colonial Exposition and Ousmane Socé's Mirages de Paris." Social Identites 8.4 (2002): 619-645.

Hitchcock, William. "Pierre Boisson, French West Africa, and the Postwar Epuration: A Case from the Aix Files. French Historical Studies. 24.2 (2001) 305-341.

Gamble, Harry. "The National Revolution in French West Africa: Dakar-Jeunes and the Shaping of African Opinion." International Journal of Francophone Studies 10.12 (2007): 85-103.

Ginio, Ruth. "Les enfants africains et la révolution nationale: La politique vichyssoise de l'enfance et de la jeunesse dans les colonies de l'AOF (1940-1943)" Revue d'histoire moderne et contemporaine. 49.4 (2002): 132-153.

---. "Marshal Petain Spoke to School Children: Vichy Propaganda in French West Africa, 1940-1943." The International Journal of African Historical Studies. 33.2 (2000): 291-312.

---. "Vichy Rule in French West Africa: A Prelude to Decolonization." French Colonial History. 4 (2003): 205-226.

---. French Colonialism Unmasked: The Vichy Years in French West Africa. Lincoln: University of Nebraska Press, 2006.

Glissant, Édouard. Introduction à une poétique du divers. Paris: Gallimard, 1996.

---. Le Discours antillais. Paris: Seuil, 1981.

Hymans, Jacques Louis. Léopold Sédar Senghor: An Intellectual Biography. Edinburgh: Edinburgh University Press, 1971.

Idowu, H. Oludare. "Assimilation in $19^{\text {th }}$ Century Senegal" Cahiers d'études africaines. 9.34 (1969): 194-218.

Irele, Abiola. "Negritude - Literature and Ideology," The Journal of Modern African Studies, 3.4 (1964): 499-526.

Jean Pierre, Wendall A. "Léopold Sédar Senghor's Freedom I-Negritude and Humanism." The Harlem Renaissance: Revaluations. Ed. Amritjit Singh. New York: Garland, 1989.

Jennings, Eric T. Vichy in the Tropics. Stanford: Stanford University Press, 2001. 
Kesteloot, Lilyan. Black Writers in French; a Literary History of Negritude.

Philadelphia: Temple University Press, 1974.

---. Les Écrivains Noirs de langue française: Naissance d'une littérature. Bruxelles: Université libre de Bruxelles, Institut de sociologie, 1965.

---. Negritude et Situation coloniale. Yaondé: Éditions Cle, 1968.

Lionnet, Françoise. Autobiographical Voices: Race, Gender, Self-Portraiture. Ithaca: Cornell UP, 1991.

---, and Shu-mei Shih, ed. Minor Transnationalism. Durham: Duke UP, 2005.

Midiohouan, Guy Ossito. L'idéologie dans la littérature négro-africaine d'expression française. Paris: L'Harmattan, 1986.

Miller, Christopher. "Hallucinations of France and Africa in the Colonial Exhibition of 1931 and Ousmane Socé's Mirages de Paris." Paragraph 18.1 (1995) 43-44.

---. Nationalists and Nomads: Essays on Francophone African Literature and Culture. Chicago: University of Chicago Press, 1998.

Ramognino, Pierre. L'Affaire Boisson: Un proconsul de Vichy en Afrique. Paris: Les Indes savantes, 2006.

Sadji, Abdoulaye. Éducation africaine et civilisation. Dakar: Imprimerie Diop, 1964.

Sadji, Amadou Booker Washington. Abdoulaye Sadji: Biographie 1910-1961: Sa vie et sa pensée à un tournant de l'histoire africaine. Paris: Présence Africaine, 1997.

Sartre, Jean-Paul. "Orphée noir," Anthologie de la nouvelle poésie nègre et malgache de langue française," (préface) ed. Léopold Sédar Senghor. Paris: PUF, 1948. xiii - xiv.

Savage, Nadine Dormoy. "Entretien avec Léopold Sédar Senghor" The French Review vol. 47, no. 6 (May 1974) 1066-1067.

Senghor, Léopold Sédar. "La résistance de la bourgeoisie sénégalaise à l'école rurale populaire." Congrès international de l'évolution culturelle des peuples coloniaux: Rapports et compte rendu. Ed. unknown. Paris: Bibliothèque nationale imprimés, 1938: 40-44.

---, and Abdoulaye Sadji. La belle histore de Leuk-le-Lièvre: Cours Élémentaire des écoles d'Afrique Noire.Vanves: EDICEF, 1953.

---. Pierre Teilhard de Chardin et la politique africaine. Paris: Seuil, 1962. 
---. Liberté I: Négritude et humanisme. Paris: Seuil, 1964.

..., and Mohamed Aziza. La Poésie De l'Action : Conversations Avec Mohamed Aziza. Paris: Stock, 1980.

Sissoko, Fily Dabo."La résistance de la bourgeoisie sénégalaise à l'école rurale populaire." Congrès international de l'évolution culturelle des peuples coloniaux: Rapports et compte rendu. Ed. unknown. Paris: Bibliothèque nationale imprimés, 1938: 116-122. [BNF]

---. Les Noirs et la culture. New York: n.p., 1950.

Wilder, Gary. The French Imperial Nation State: Négritude and Colonial Humanism Between Two World Wars. Chicago : University of Chicago Press, 2005.

Vaillant, Janet. Black, French, and African: A Life of Léopold Sédar Senghor. Cambridge: Harvard University Press, 1990.

\section{PRESS AND ARCHIVAL MATERIALS}

Boisson, Pierre. "Dominer les événements au lieu de les subir" Dakar-Jeunes. 8 Jan. 1942: 1. [ANS]

Césaire, Aimé. “Jeunesse noir et assimilation.” L'Étudiant noir 1 (1935): 3.

Coulibaly, Ouezzin. "Copier servilement la culture occidentale, c'est nuire à la personnalité de nos races." Dakar-Jeunes 26 Feb. 1946: 3. [ANS]

Dia, Mamadou. "Fine analyse de la crise de conscience d'une génération." Paris-Dakar 20 Jul. 1937: 2. [CRL]

---. "Pour ou contre... Une culture africaine." Dakar-Jeunes 12 Mar. 1942: 10. [ANS]

Kalande. "Une mise au point." Dakar-Jeunes 12 Feb. 1942: 2. [ANS]

M.H. "La plus vieille dynastie du monde est africaine: Elle règne toujours en Ethiopie."Bingo February 1960: 14. [ANS]

Myrau. "Défense de M. Ousmane Socé." Paris-Dakar 29 Oct. 1937: 2. [CRL]

Sadji, Abdoulaye. "Une ame qui vibrait dans un corps frêle." Paris-Dakar 6 Mar. 1937: 2. [CRL]

---. "Le conte indigène de la moralité des indigènes." Paris-Dakar 17 Apr. 1937: 2. 


\section{[CRL]}

---. "Ce que disent les mélopées sénégalaises.” Paris-Dakar 11 May 1937: 2 ; 24 May

1937: 2 ; 1 Jun. 1937: 2 ;15 Jun. 1937: 2 ; 29 Jun. 1937: 2. [CRL]

---. "Notre conte: Chien et Singe." Paris-Dakar 8 Jun. 1937: 2. [CRL]

---. "Mirages de Paris: Préface" Paris-Dakar 12 Jun. 1937: 5. [CRL]

---. “Gallo M'Baye griot de Rufisque.” Paris-Dakar. 27 Jul. 1937: 2. [CRL]

---. “Utopie et Réalité.” Paris-Dakar 6 Oct. 1937: 2. [CRL]

---. "Le surhomme de Nietzsche." Paris-Dakar 13 Oct. 1937: 2. [CRL]

---.“Un point de vue.” Dakar-Jeunes 12 Mar. 1942: 10. [CRL]

---. "La sage bêtise de l'hyène.” Dakar-Jeunes 9 Apr. 1942: 2. [ANS]

Socé, Ousmane. "Le cercle vicieux est rompu...” Paris-Dakar 9 Jan. 1937: 1. [CRL]

---. "Le mariage et l'évolution sénégalaise." Paris-Dakar 14 Apr. 1937: 1. [CRL]

---. "Impressions d'Europe." Paris-Dakar 3 Aug. 1937: 2; 6 Aug. 1937: 2. [CRL]

---. “Le Danger." Paris-Dakar 28 Sept. 1937: 2. [CRL]

---. "La legend de Ghana." Paris-Dakar 11 Mar. 1938: 2. [CRL]

---. "Autour du Congrès de l'Évolution culturelle des peoples coloniaux." Paris-Dakar 4 Jan. 1939: 1, 5. [CRL]

---. "Les noirs et la culture: Réponse à M. Fily Dabo Sissoko." Paris-Dakar 8 Feb. 1939: 5; 9 Feb. 1939: 5; 10 Feb. 1939: 5. [CRL]

---."L'évolution culturelle de l'A.O.F." Dakar-Jeunes 29 Jan. 1942: 2. [ANS]

---. "Karim 1942." Dakar-Jeunes 26 Feb. 1942: 3; 26 Mar. 1942: 3; 5 May 1942: 3; 11 Jun. 1942: 3; 27 Aug. 1942: 3; 29 Oct. 1942: 4; 31 Dec. 1942: 3. [ANS]

---."Nations, Nègres et Culture: En lisant Cheikh Anta Diop." Bingo Dec. 1955 ; Jan. 1956 ; Feb. 1956 ; Mar. 1956 ; Apr. 1956 ; May 1956 ; Jun. 1956 ; July 1956 ; Aug. 1956. [ANS]

Sow, Fara. "La jeunesse se confie à Dakar-Jeunes." Dakar-Jeunes 5 Mar. 1942: 2. [ANS] 
Senghor, Léopold Sédar. "Les conditions nécessaires de l'action." L'Afrique Nouvelle: Bulletin Mensuel du Foyer France-Sénégal 1 (Septembre 1936): 4. [ANS]

---. [Title unknown]. L'Afrique Nouvelle: Bulletin Mensuel du Foyer France-Sénégal no. 3 (Novembre et Décembre 1936): 4. [ANS]

---. "Réflexions sur l'éducation africaine: De l'assimilation." Paris-Dakar 6 Jan. 1937: 1. [CRL]

---. "Réflexions sur l'éducation africaine: L'école rurale populaire." ParisDakar 9 Jan. 1937: 1. [CRL]

---. "Réflexions sur l'éducation africaine: L'école professionnelle." Paris-Dakar 30 Apr. 1937: 1. [CRL]

---. "Le problème culturel en A.O.F. Paris-Dakar 8 Sept. 1937: 2. [CRL]

---, Birago Diop and Amadou Cissé Dia.“Adieu à Ousmane Socé Diop,” Bingo May 1974: 20. [ANS]

Sissoko, Fily Dabo. "Réponse à Ousmane Socé: A propos du Congrès de l'Évolution Culturelle des peuples coloniaux," Paris-Dakar 27 Jan. 1939: 1, 5. [CRL]

Thibault, J.H. "Fille du Vice Président du government de la Haute Volta, Mlle Denise Ouezzin est à 17 ans et demi la première femme pilote de l'A.O.F.," Bingo July 1958: 9. [ANS]

Tovalou Houenou, Kojo. "Etrennes d'un indigène à ses frères" Le Libéré: Tribune du peuple malgache 15 Jan. 1924: 1. [BNF]

\section{AUTHOR UNKNOWN (PRESS):}

“Déclaration.” Le Libéré: Tribune du peuple malgache 15 May 1923: 1. [BNF]

"La conférence de M. Socé a remporté un succès triomphal à la Chambre de Commerce." Paris-Dakar 3 Aug. 1937: 1. [CRL]

Bulletin Quotidien de la Chambre de Commerce de Dakar: $2^{\mathrm{e}}$ année no. 3236, 28-29 Aug. 1937: 2. [IFAN]

“Tel est le sujet qui traitera ce soir M. Léopold Sédar Senghor," Paris-Dakar 4 Sept. 1937: 1. [CRL]

“L'empire toucouleur d'El Hadj Omar.” Bingo May 1958: 11. [ANS] 
"Licenciée en Droit en Juin, Mme Diop Ousmane Socé sera-t-elle bientôt la première avocate africaine d'A.O.F." Bingo Sept. 1958: 3. [ANS]

"Le Sénégal dans la peine: Le Docteur Ousmane Socé Diop est mort samedi" Le Soleil 30 Oct. 1937: 1, 3. [ANS] 